\author{
Universidade de São Paulo \\ Faculdade de Filosofia, Letras e Ciências Humanas \\ Departamento de Geografia
}

\title{
O DESAFIO DA MANUTENÇÃO DO ABASTECIMENTO HÍDRICO NA REGIÃO METROPOLITANA DE SÃO PAULO: BUSCA POR UMA GESTÃO SUSTENTÁVEL.
}

(versão corrigida)

Gabriela Narcizo de Lima

São Paulo

2015 


\section{O DESAFIO DA MANUTENÇÃO DO ABASTECIMENTO HÍDRICO NA REGIÃO METROPOLITANA DE SÃO PAULO: BUSCA POR UMA GESTÃO SUSTENTÁVEL.}

Tese apresentada ao Departamento de Geografia da Faculdade de Filosofia, Letras e Ciências Humanas da Universidade de São Paulo para obtenção do título de Doutora em Geografia Física Orientadora: Prof. ${ }^{a}$ Dr. ${ }^{a}$ Magda Adelaide Lombardo

Versão corrigida

De acordo
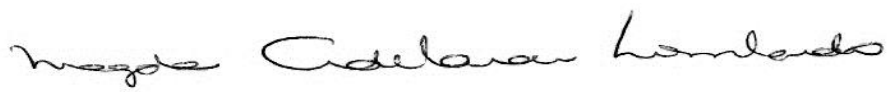

Prof. ${ }^{\text {a }}$ Dr. ${ }^{\text {a }}$ Magda Adelaide Lombardo

São Paulo 
Autorizo a reprodução e divulgação total ou parcial deste trabalho, por qualquer meio convencional ou eletrônico, para fins de estudo e pesquisa, desde que citada a fonte.

Catalogação na Publicação

Serviço de Biblioteca e Documentação

Faculdade de Filosofia, Letras e Ciências Humanas da Universidade de São Paulo

L732d

Lima, Gabriela Narcizo de

o desafio da manutenção do abastecimento hídrico na Região Metropolitana de São Paulo: busca por uma gestão sustentável. / Gabriela Narcizo de Lima ; orientadora Magda Adelaide Lombardo. - São Paulo, 2015.

$200 \mathrm{f}$.

Tese (Doutorado)- Faculdade de Filosofia, Letras e Ciências Humanas da Universidade de São Paulo. Departamento de Geografia. Área de concentração: Geografia Física.

1. Região Metropolitana de São Paulo. 2 . Precipitação. 3. Abastecimento Hídrico. 4. Clima Urbano. I. Lombardo, Magda Adelaide, orient. II. Título. 


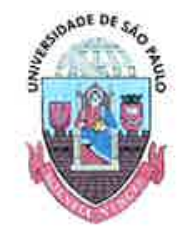

Janus

\author{
Universidade de São Paulo
}

\title{
ATA DE DEFESA
}

Aluno: 8135 - 7671836 - 2 / Página 1 de 1

ata de defesa pública de Tese do(a) Senhor(a) Gabriela Narcizo de Lima no Programa: Geografia (Geografia Física), do(a) Faculdade de Filosofia, Letras e Ciências Humanas da Universidade de São Paulo.

Aos 16 dias do mês de outubro de 2015, no(a) Sala de Defesas realizou-se a Defesa da Tese do(a) Senhor(a) Gabriela Narcizo de Lima, apresentada para a obtenção do título de Doutora intitulada:

"O desafio da manutenção do abastecimento hídrico na região metropolitana de São Paulo: busca por uma gestão sustentável"

Após declarada aberta a sessão, o(a) Sr(a) Presidente passa a palavra ao candidato para exposição e a seguir aos examinadores para as devidas arguições que se desenvolvem nos termos regimentais. Em seguida, a Comissão Julgadora proclama o resultado:

$\begin{array}{llll}\text { Nome dos Participantes da Banca } & \text { Função } & \text { Sigla da CPG } & \text { Resultado } \\ \text { Magda Adelaide Lombardo } & \text { Presidente } & \text { FFLCH - USP } & \text { Aprovado } \\ \text { Jose Bueno Conti } & \text { Titular } & \text { FFLCH - USP } & \text { Aprovado } \\ \text { Jefferson Lordello Polizel } & \text { Titular } & \text { Docente Externo } & \text { Aprovado } \\ \text { Andreia Medinilha Pancher } & \text { Titular } & \text { UNESP - Externo } & \text { Aprovado } \\ \text { Demóstenes Ferreira da Silva Filho } & \text { Titular } & \text { ESALQ - USP } & \text { Aprovado }\end{array}$

Resultado Final: Aprovado

\section{Parecer da Comissão Julgadora *}

Em virtude da alta qualidade e inegável mérito científico, a pesquisa é aprovada e a banca recomenda sua publicação após serem incorporadas as sugestões dos examinadores.

Eu, Aline Nogueira Marques Nicolau , lavrei a presente ata, que assino juntamente com os(as) Senhores(as) examinadores. São Paulo, tos-16 dias-dg mês de outubro de 2015.
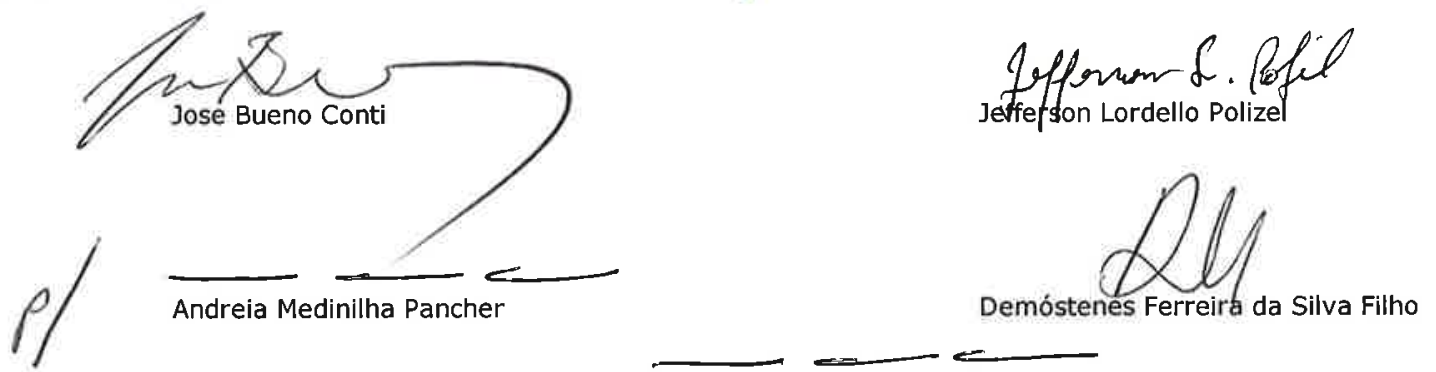

Magda Adelaide Lombardo Presidente da Comissão Julgadora

* Obs: Se o candidato for reprovado por algum dos membros, o preenchimento do parecer é obrigatório.

A defesa foi homologada pela Comissão de Pós-Graduação em $16 / 10,2015$ e, portanto, o(a) aluno(a) faz jus ao título de Doutora em Ciências obtido no Programa Geografia (Geografia Física) - Área de concentração: Geografia Física.

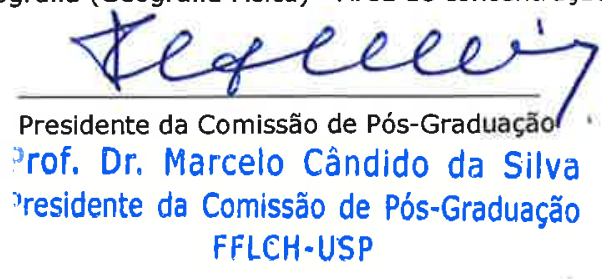




\section{SUMÁRIO}

1. INTRODUÇÃO E JUSTIFICATIVA

2. HIPÓTESE DE TRABALHO 09

3. OBJETIVOS 15

3.1 Objetivos Gerais 15

3.2 Objetivos Específicos 15

4. REFERENCIAL TEÓRICO 16

4.1 As paisagens urbanas e a alteração no clima 17

4.2 As pesquisas em climatologia pelo mundo 23

4.3 As pesquisas de climatologia no Brasil 34

4.4 As pesquisas sobre a Região Metropolitana de São Paulo 40

4.5 A Água e a Gestão dos Recursos Hídricos 46

5. PROCEDIMENTOS METODOLÓGICOS 51

5.1 Bases teórico-metodológicas

5.2 Metodologia 55

6. O FENÔMENO DA URBANIZAÇÃO E SEUS IMPACTOS

6.1 O processo de urbanização no Brasil 57

6.2 Caracterização da área de estudo 61

6.2.1 O processo de urbanização na Região Metropolitana de São Paulo 61

6.2.2 O sítio urbano e o contexto climático da Região Metropolitana de São

$\begin{array}{ll}\text { Paulo } & 68\end{array}$

6.2.2.1 Uso e Ocupação do Solo na Região Metropolitana de São Paulo 72

6.2.3 Recursos hídricos na Região Metropolitana de São Paulo 85

6.2.3.1 Histórico do abastecimento de água na Região Metropolitana de São

Paulo $\quad 89$

6.2.3.2 O abastecimento de água na Região Metropolitana de São Paulo -

Cenário atual

7. ANÁLISES DAS SÉRIES HISTÓRICAS DOS DADOS DE

PRECIPITAÇÃO DA REGIÃO METROPOLITANA DE SÃO PAULO 101

7.1 Levantamento e análise estatística das Séries de Dados 101

7.2 Análise das séries de totais pluviométricos anuais e sazonais 108 
7.2.1 Análise das séries de frequência de dias com precipitação acima de $20 \mathrm{~mm}$.

7.3 Análise dos volumes de armazenamento dos mananciais da RMSP 143

8. CONSIDERAÇÕES FINAIS 150

9. REFERÊNCIAS BIBLIOGRÁFICAS 156

APÊNDICES 170

$\begin{array}{ll}\text { Apêndice } 01 & 172\end{array}$

Apêndice $02 \quad 183$

$\begin{array}{ll}\text { ANEXO } & 185\end{array}$ 


\section{LISTA DE FIGURAS}

Figura 01: Localização da Região Metropolitana de São Paulo 02

Figura 02: Sub-bacias do Alto Tietê. 10

Figura 03: Crescimento da Região Metropolitana de São Paulo e Ocupação de Áreas de Interesse Ambiental - 2010.

Figura 04: Região Metropolitana de São Paulo - Complementaridades Funcionais $\quad 64$

Figura 05: Municípios da Região Metropolitana de São Paulo 65

Figura 06: Região Metropolitana de São Paulo - Mancha Urbana Contínua 67

Figura 07: Mapa de Uso e Ocupação do Solo - Sub-região Norte 74

Figura 08: Mapa de Uso e Ocupação do Solo - Sub-região Oeste 76

Figura 09: Mapa de Uso e Ocupação do Solo - Sub-região Sudoeste 78

Figura 10: Mapa de Uso e Ocupação do Solo - Sub-região Leste 80

Figura 11: Mapa de Uso e Ocupação do Solo - Sub-região Leste $\quad 82$

Figura 12: Mapa de Uso e Ocupação do Solo - Sub-região Leste $\quad 84$

Figura 13: Unidades de Gerenciamento dos Recursos Hídricos do Estado de São

Paulo

Figura 14: Proposta de Retificação do Rio Tietê e Construção de Avenidas Marginais - Prefeito Prestes Maia - Década de 1940.

Figura 15: Bacia Hidrográfica do Alto Tietê 95

Figura 16: Sistemas de Abastecimento na Região Metropolitana de São Paulo 98

Figura 17: Localização das Estações Meteorológicas e Postos Pluviométricos

Selecionados - RMSP

Figura18: Localização e entorno dos Postos Pluviométricos e Estações

Meteorológicas selecionada. $\quad 105$

Figura 19: Método da Dupla Massa - Inconsistências 107

Figura 20: Pluviosidade anual na Região Metropolitana de São Paulo 135 


\section{LISTA DE GRÁFICOS}

Gráfico 01: Valores anuais de alturas pluviométricas - IAG 109

Gráfico 02: Valores anuais de alturas pluviométricas - Guarulhos 109

Gráfico 03: Valores anuais de alturas pluviométricas - Fazenda São Bento 110

Gráfico 04: Valores anuais de alturas pluviométricas - Santa Isabel 110

Gráfico 05: Valores anuais de alturas pluviométricas - Mirante de Santana 111

Gráfico 06: Valores anuais de alturas pluviométricas - Monte Belo 111

Gráfico 07: Valores anuais de alturas pluviométricas - Cachoeira da Graça 112

Gráfico 08: Valores anuais de alturas pluviométricas - Juquitiba 113

Gráfico 09: Valores anuais de alturas pluviométricas - Baixo Cotia 113

Gráfico 10: Valores anuais de alturas pluviométricas - Ponte Nova 114

Gráfico 11: Valores trimestrais de alturas pluviométricas - Trimestre Verão - Ponte $\begin{array}{ll}\text { Nova } & 114\end{array}$

Gráfico 12: Valores trimestrais de alturas pluviométricas - Trimestre Verão Fazenda São Bento $\quad 115$

Gráfico 13: Valores trimestrais de alturas pluviométricas - Trimestre Verão - IAG 115

Gráfico 14: Valores trimestrais de alturas pluviométricas - Trimestre Verão Mirante de Santana

Gráfico 15: Valores trimestrais de alturas pluviométricas - Trimestre Verão - Santa Isabel

Gráfico 16: Valores trimestrais de alturas pluviométricas - Trimestre Verão - Santa Isabel

Gráfico 17: Valores trimestrais de alturas pluviométricas - Trimestre Verão Juquitiba

Gráfico 18: Valores trimestrais de alturas pluviométricas - Trimestre Verão - Ponte Nova

Gráfico 19: Valores trimestrais de alturas pluviométricas - Trimestre Verão - Baixo Cotia

Gráfico 20: Valores trimestrais de alturas pluviométricas - Trimestre Outono Fazenda São Bento

Gráfico 21: Valores trimestrais de alturas pluviométricas - Trimestre Outono - IAG

Gráfico 22: Valores trimestrais de alturas pluviométricas - Trimestre Outono - 
Mirante de Santana

Gráfico 23: Valores trimestrais de alturas pluviométricas - Trimestre Outono - Santa Isabel

Gráfico 24: Valores trimestrais de alturas pluviométricas - Trimestre Outono Monte Belo

Gráfico 25: Valores trimestrais de alturas pluviométricas - Trimestre Outono Cachoeira da Graça

Gráfico 26: Valores trimestrais de alturas pluviométricas - Trimestre Outono Guarulhos

Gráfico 27: Valores trimestrais de alturas pluviométricas - Trimestre Outono Baixo Cotia

Gráfico 28: Valores trimestrais de alturas pluviométricas - Trimestre Outono Juquitiba

Gráfico 29: Valores trimestrais de alturas pluviométricas - Trimestre Outono Ponte Nova

Gráfico 30: Valores trimestrais de alturas pluviométricas - Trimestre Inverno Baixo Cotia

Gráfico 31: Valores trimestrais de alturas pluviométricas - Trimestre Inverno Cachoeira da Graça

Gráfico 32: Valores trimestrais de alturas pluviométricas - Trimestre Inverno Santa Isabel

Gráfico 33: Valores trimestrais de alturas pluviométricas - Trimestre Inverno - IAG

Gráfico 34: Valores trimestrais de alturas pluviométricas - Trimestre Inverno Mirante de Santana

Gráfico 35: Valores trimestrais de alturas pluviométricas - Trimestre Inverno Monte Belo

Gráfico 36: Valores trimestrais de alturas pluviométricas - Trimestre Inverno Fazenda São Bento

Gráfico 37: Valores trimestrais de alturas pluviométricas - Trimestre Inverno Guarulhos

Gráfico 38: Valores trimestrais de alturas pluviométricas - Trimestre Inverno Juquitiba

Gráfico 39: Valores trimestrais de alturas pluviométricas - Trimestre Inverno - 
Ponte Nova

Gráfico 40: Valores trimestrais de alturas pluviométricas - Trimestre Primavera Guarulhos

Gráfico 41: Valores trimestrais de alturas pluviométricas - Trimestre Primavera Mirante de Santana

Gráfico 42: Valores trimestrais de alturas pluviométricas - Trimestre Primavera IAG

Gráfico 43: Valores trimestrais de alturas pluviométricas - Trimestre Primavera Santa Isabel

Gráfico 44: Valores trimestrais de alturas pluviométricas - Trimestre Primavera Baixo Cotia

Gráfico 45: Valores trimestrais de alturas pluviométricas - Trimestre Primavera Juquitiba

Gráfico 46: Valores trimestrais de alturas pluviométricas - Trimestre Primavera Fazenda São Bento

Gráfico 47: Valores trimestrais de alturas pluviométricas - Trimestre Primavera Monte Belo

Gráfico 48: Valores trimestrais de alturas pluviométricas - Trimestre Primavera Cachoeira da Graça

Gráfico 49: Valores trimestrais de alturas pluviométricas - Trimestre Primavera Ponte Nova

Gráfico 50: Frequência de dias com precipitação a partir de 20 mm - IAG (1933 a 1959)

Gráfico 51: Frequência de dias com precipitação a partir de 20 mm - IAG (1960 a 1986)

Gráfico 52: Frequência de dias com precipitação a partir de $20 \mathrm{~mm}$ - Mirante de Santana (1961 a 1987)

Gráfico 53: Frequência de dias com precipitação a partir de 20 mm - IAG (1987 a 2013)

Gráfico 54: Frequência de dias com precipitação a partir de $20 \mathrm{~mm}$ - Mirante de Santana (1988 a 2013)

Gráfico 55: Frequência de dias com precipitação a partir de $20 \mathrm{~mm}$ - Guarulhos (1987 a 2013) 
Gráfico 56: Histograma Comparado - Frequência de dias com precipitação a partir de 20 mm - IAG (1933 a 2013)

Gráfico 57: Histograma Comparado - Frequência de dias com precipitação a partir de 20 mm - Mirante de Santana (1961 a 2013)

Gráfico 58: Volume de armazenamento dos mananciais da RMSP - Trimestre de Verão

Gráfico 59: Volume de armazenamento dos mananciais da RMSP - Trimestre de Outono

Gráfico 60: Volume de armazenamento dos mananciais da RMSP - Trimestre de Inverno

Gráfico 61: Volume de armazenamento dos mananciais da RMSP - Trimestre de Primavera

Gráfico 62: Volumes anuais de armazenamento dos mananciais da RMSP

\section{LISTA DE TABELAS}

Tabela 01: Taxas anuais de crescimento populacional (\%): RMSP, Estado de São Paulo, Brasil 1940 - 2010

Tabela 02: Estações Meteorológicas e Postos Pluviométricos selecionados 
Dedico aos meus pais. Haria o Luir lin memoriam t, que viram esse babalho nascers mas näo liveram a fportunidade de vé lo acabado.

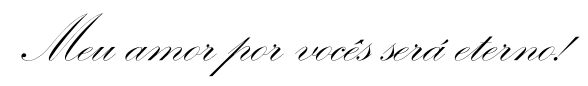


Agradeço inicialmente ao Conselho Nacional de Desenvolvimento Científico e Tecnológico (CNPq) pelo auxílio ao longo do desenvolvimento deste trabalho;

A DEUS, Pai de infinita bondade, que iluminou meus caminhos durante toda esta jornada;

A minha orientadora e amiga Magda Adelaide Lombardo, pelo auxílio na vida acadêmica e pessoal;

Aos professores Victor Magaña, Ernesto dos Santos Caetano Neto e a todos os companheiros do grupo de pesquisa "Clima y Sociedad" do Instituto de Geografia da Universidad Nacional Autónoma de México, pela maravilhosa recepção e importantes ensinamentos;

A toda minha família, e em especial meus pais (Luiz e Maria Natalina) (in memoriam) e irmãos (Natália, Sebastião), que mesmo na distância, me amaram e apoiaram incondicionalmente;

Ao meu amado David Alejandro, pelo apoio e carinho que me dedica todos os dias;

As queridas amigas Jacqueline e Thais que se tornaram verdadeiras irmãs de vida;

E por fim, a todos os professores e amigos que passaram pela minha vida e ficaram marcados em meu coração de diferentes formas.

Muito Obrigada a Todos. 


\section{Resumo}

As cidades constituem a forma mais radical de transformação da paisagem natural, pois seus impactos não se limitam a mudar a morfologia do terreno no qual se inserem, modificam, também, as condições ambientais e climáticas, gerando, assim, um espaço eminentemente antropizado, no qual a atuação do homem se manifesta direta ou indiretamente e cujos resultados mais significativos são a degradação ambiental e a geração de um clima específico dos centros urbanos. A Região Metropolitana de São Paulo (RMSP) é o melhor exemplo nacional do ritmo da urbanização brasileira, e a intensificação desse processo culminou na expansão de parques industriais, implantação de sistemas viários e construção de edifícios, provocando alterações nas características climáticas da região, em especial nos últimos 30 anos, onde tem sido registrada uma tendência de chuvas anômalas. Ao mesmo tempo, a Região Metropolitana de São Paulo apresenta um dos quadros mais críticos do país no que diz respeito à garantia de água em quantidade e qualidade suficiente para o abastecimento de sua população. Assim, esta pesquisa buscou analisar se as alterações climáticas (em especial nas precipitações) decorrentes do processo de urbanização estão relacionadas com os problemas de abastecimento urbano detectados na Região Metropolitana de São Paulo (RMSP), ou se os mesmos são decorrentes de uma gestão deficiente e do rápido crescimento das cidades. De uma maneira geral, o que se pôde concluir com resultados dessa pesquisa é que eles apontam no sentido de que existem indícios de efeitos da urbanização sobre o comportamento das chuvas na RMSP, tais como uma tendência a elevação dos totais pluviométricos sazonais e anuais e o aumento da ocorrência de episódios com chuvas mais intensas (acima de $20 \mathrm{~mm}$ ), registradas principalmente em estações localizadas em áreas densamente urbanizadas. Notou-se, também, que as médias dos volumes armazenados nos reservatórios que abastecem a RMSP não apresentaram um comportamento padrão, pois, mesmo em condições climáticas semelhantes, alguns reservatórios possuíam um elevado volume de água armazenado, enquanto outros oscilavam rapidamente, sendo registrados, muitas vezes, valores bem abaixo de sua capacidade. Seria necessária uma adaptação aos novos padrões de chuvas identificados (tendências positivas de aumento de precipitação e chuvas intensas concentradas em períodos mais curtos), para que fosse possível a manutenção do abastecimento hídrico para população nos próximos anos.

Palavras chave: Região Metropolitana de São Paulo, Precipitação, Abastecimento Hídrico, Clima Urbano. 


\begin{abstract}
Cities are the most radical transformation of the natural landscape because its impacts are not limited to changing the morphology of the land on which they are inserted, they also modify the environmental and climatic conditions, thus generating a highly anthropic space, on which the action of man is manifested directly or indirectly and whose most significant results are environmental degradation and the generation of a specific climate of urban centers. The São Paulo Metropolitan Region (SPMR) is the best national example of the Brazilian urbanization pace, and the intensification of this process culminated in the expansion of industrial parks, implementation of road systems and construction of buildings, causing changes in climatic characteristics of the region, especially in the last 30 years in which it has been registered a trend of anomalous rainfall. At the same time, the São Paulo Metropolitan Region has one of the most critical situations of the country with regard to water security in sufficient quantity and quality to supply its population. So, this study aimed to examine whether climate changes (especially in rainfall) resulting from the urbanization process are related to the urban supply problems detected in the São Paulo Metropolitan Region, or whether they are due to poor management and the rapid growth of cities. Broadly, what can be concluded from the results of this research is that they indicate that there are signs of urbanization effects on the behavior of rainfall in the SPMR, such as a tendency to rise in seasonal and annual rainfall totals and the increased episodes with more intense rain (above $20 \mathrm{~mm}$ ) mainly recorded in stations located in densely urbanized areas. It was also identified that the averages of the volumes stored in the reservoirs which supply the São Paulo Metropolitan Region did not have a default behavior, because even in similar weather conditions, some reservoirs had a high volume of stored water while others oscillated, rapidly being logged, often showing values well below capacity. An adaptation to new patterns of identified rains (positive trends of increased precipitation and heavy rainfall concentrated in shorter periods) would be required, to be possible to maintain the water supply to population in the upcoming years.
\end{abstract}

Keywords: São Paulo Metropolitan Region, Rainfall, Water Supply, Urban Climate. 


\section{Resumen}

Las ciudades constituyen la forma más radical de transformación del paisaje natural, pues sus impactos no se limitan a cambiar la morfología del terreno en el cual se asientan, modifican, también, las condiciones ambientales y climáticas, generando así, un espacio eminentemente antropizado en el cual la acción del hombre se manifiesta directa 0 indirectamente y cuyos resultados más significativos son la degradación ambiental y la generación de un clima específico de los centros urbanos. La Región Metropolitana de São Paulo (RMSP) es el mejor ejemplo nacional del ritmo de la urbanización brasileña, y la intensificación de ese proceso culminó en la expansión de parques industriales, implantación de sistemas viales y construcción de edificios, provocando alteraciones en las características climáticas de la región, en especial en los últimos 30 años, donde se registró una tendencia de lluvias anómalas. Al mismo tiempo, la RMSP presenta uno de los cuadros más críticos del país en lo que respecta a la garantía de agua en cantidad y calidad suficiente para el abastecimiento de su población. Así, esta investigación buscó analizar si las alteraciones climáticas (en especial las precipitaciones) vinculadas con el proceso de urbanización están relacionadas con los problemas de abastecimiento urbano detectados en la RMSP, o si los mismos son provocados por una administración deficiente y del rápido crecimiento de las ciudades. De manera general, lo que se puede concluir con los resultados de este trabajo es que existen indicios de efectos de la urbanización con el comportamiento de las lluvias en la RMSP, tales como una tendencia al aumento de los totales pluviométricos estacionales y anuales y el aumento de frecuencia de episodios con lluvias más intensas (arriba de $20 \mathrm{~mm}$ ) registradas principalmente en estaciones localizadas en áreas densamente urbanizadas. Notamos también que las medias de los volúmenes almacenados en los reservatorios que abastecen la RMSP no presentan un comportamiento estándar, pues aun en condiciones climáticas semejantes, algunos reservatorios presentaban un elevado volumen de agua almacenado, en cuanto otros oscilaban rápidamente, siendo registrados muchas veces valores mucho menor a su capacidad. Sería necesaria una adaptación a los nuevos patrones de lluvias identificados (tendencias positivas de aumento de precipitación y lluvias intensas concentradas en periodos más cortos), para que sea posible la manutención del abastecimiento hídrico para población en los próximos años.

Palabras clave: Región Metropolitana de São Paulo, Precipitación, Abastecimiento Hídrico, Clima Urbano. 


\section{Introdução e Justificativa:}

As cidades são sistemas complexos, caracterizando-se como organismos extremamente dinâmicos, suscetíveis a entrada de fluxos de energia e massa. A importância crescente das áreas urbanas em termos demográficos, econômicos e culturais faz com que os problemas ambientais gerados por estes núcleos sejam cada vez mais uma prioridade para pesquisadores de diversas áreas, pois os mesmos podem afetar diretamente a qualidade de vida das pessoas que aí residem.

O processo de produção capitalista, que ganhou força no século XIX, foi o principal gerador do crescente fenômeno de urbanização mundial, sustentando-se principalmente na industrialização, que gerou um rápido aumento produtivo e levou o homem do campo para as cidades. No Brasil, este fenômeno ganhou visibilidade entre as décadas de 1950 e 1960, e vem crescendo continuamente desde então.

A Região Metropolitana de São Paulo (RMSP) (Figura 01) é o melhor exemplo nacional do ritmo da urbanização brasileira, tanto que na década de 1950 já se falava em Grande São Paulo (GSP), e a cidade recebia denominações que atestavam o surgimento de uma nova realidade urbana.

Ao mesmo tempo em que ocorriam os processos de verticalização, implantação de novas rodovias, industrialização, abertura de avenidas, expansão do setor econômico e bancário, e o desenvolvimento dos meios de comunicação, cresciam também bairros periféricos e populares a sudeste e a leste, frutos da forte especulação imobiliária e da maior difusão do transporte coletivo. 


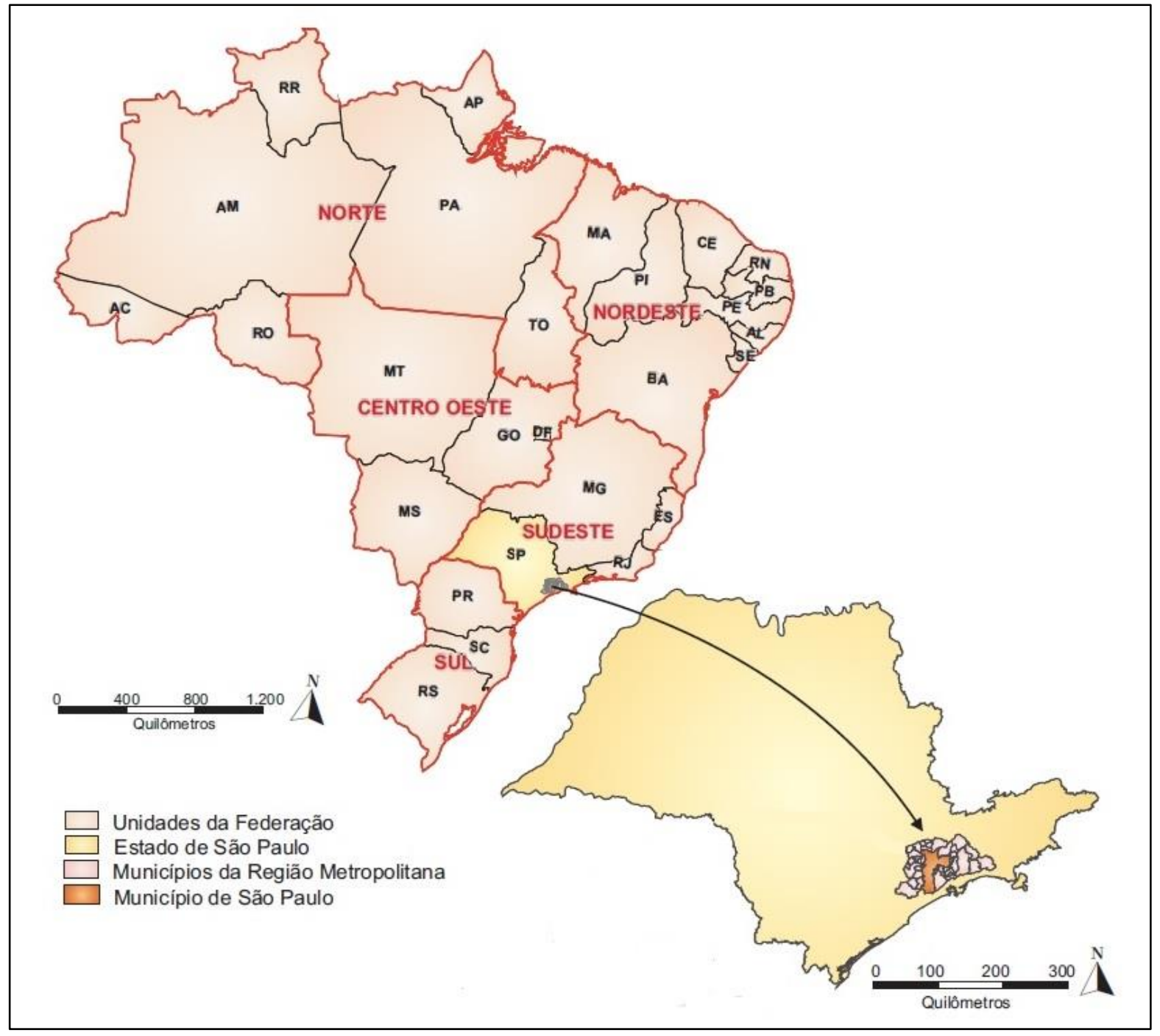

Figura 01: Localização da Região Metropolitana de São Paulo

Fonte (Base Cartográfica): Instituto Brasileiro de Geografia e Estatística (IBGE)

Org.: Lima (2014)

Souza (1994, p.50) descreve esse período como "[...] fase de enorme caos urbano - símbolo de um crescimento incontrolado". A maior evidência dessa afirmação era a crise habitacional e a precariedade na oferta de serviços públicos principalmente para os bairros populares da periferia.

No período que vai de 1960 a 1980 consolida-se a metrópole, que teve sua criação definitiva em 1973, passando a se chamar Região Metropolitana de São Paulo (RMSP).

As cidades, ao lado das atividades mineradoras, constituem a forma mais radical de transformação da paisagem natural, pois seus impactos não se 
limitam a mudar a morfologia do terreno no qual se inserem, modificam, também, as condições ambientais e climáticas, gerando, assim, um espaço eminentemente antropizado, no qual a atuação do homem se manifesta direta ou indiretamente e cujos resultados mais significativos são a degradação ambiental e a geração de um clima específico dos centros urbanos.

É neste contexto que a geografia pode contribuir de maneira efetiva, tanto no diagnóstico, como na avaliação e mitigação dos inúmeros impactos ambientais herdados da aplicação das políticas tradicionais de crescimento econômico, que excluem a ideia da conservação ambiental e da manutenção da qualidade de vida das populações no processo de desenvolvimento.

Como as cidades são dinâmicas, ou seja, tendem a se transformar constantemente, ampliando-se horizontal e verticalmente, provocam com frequência novas e maiores alterações no ambiente que as cercam.

Dependendo do grau ou da intensidade das modificações no meio natural, os desequilíbrios são inevitáveis. Uma das respostas que o meio nos dá é através de modificações na dinâmica climática. A evolução, ou seja, o tempo necessário para restabelecer a nova dinâmica depende do grau de intervenção e também do nível de fragilidade do geossistema.

Nesta perspectiva insere-se esta pesquisa, que visa analisar se as alterações climáticas (em especial nas precipitações) decorrentes do processo de urbanização estão relacionadas com os problemas de abastecimento urbano detectados na Região Metropolitana de São Paulo (RMSP), ou se os mesmos são decorrentes de uma gestão deficiente e do rápido crescimento das cidades.

Criada pela Lei Complementar no 14, de oito de Julho de 1973, a Região Metropolitana de São Paulo é composta por 39 municípios, incluindo a 
capital do estado (São Paulo). Segundo dados do Censo Demográfico do IBGE do ano de 2010, a população total é de 19.672.582 habitantes.

O crescimento populacional na Região Metropolitana de São Paulo acompanhou seu desempenho econômico. No século XIX, durante o ciclo do café, São Paulo passou a comandar um processo de enriquecimento e desenvolvimento em relação ao resto do país que se estende até os dias de hoje. Já em meados do século XX iniciou-se o processo de industrialização pesada, que veio como consequência da infraestrutura já implantada e do capital acumulado.

O município de São Paulo sempre foi o principal cenário deste desenvolvimento, ao lado de seus vizinhos São Bernardo, Diadema, São Caetano do Sul, Santo André, Mogi das Cruzes, além de Guarulhos e Osasco, que já apresentavam uma industrialização anterior.

De acordo com Custódio (2012), após os anos 1960, a ausência de condições de oportunidades efetivas no mercado de trabalho urbano, associada aos baixos salários pagos aos menos qualificados, propiciou o início de um processo crescente de ocupações irregulares.

Já em meados dos anos de 1970 iniciou-se um período de desconcentração de atividades para áreas situadas principalmente no entorno próximo à Metrópole, notadamente no eixo Campinas, Vale do Paraíba e Sorocaba.

Apesar do declínio da produção industrial, tanto na Região Metropolitana de São Paulo, como na capital, e da redução drástica da taxa de crescimento populacional em quase todos seus municípios, a área urbanizada continuou crescendo, graças a sua recuperação mediante estímulo de novas vocações como prestação de serviços, nas áreas de turismo, lazer, finanças, 
saúde e educação, ou ainda em atividades industriais ligadas às pequenas e médias empresas.

Há previsões de uma tendência à relativa estabilização no processo de ocupação da área metropolitana, em que pese o crescimento das atividades de comércio e serviços. Porém a tendência geral de estabilização não é uniformemente distribuída no território metropolitano; as áreas periféricas continuaram a crescer, assim como o processo de favelização.

O sítio urbano da RMSP está localizado no Planalto Paulistano, que apresenta-se dividido em dois compartimentos: a Borda Cristalina e a Bacia Sedimentar de São Paulo. A Borda Cristalina envolve a Bacia Sedimentar a leste, oeste e sul e é formada por rochas cristalinas suscetíveis à forte erosão, apresenta altitudes entre $850 \mathrm{~m}$ e $1.100 \mathrm{~m}$, fortes declividades, intenso conjunto de rios, inclusive com nascentes importantes. A ocupação urbana nessa região é inadequada, pois sem a vegetação, os processos erosivos são favorecidos, além de caracterizar-se como a área onde nascem alguns dos principais cursos de água da Região Metropolitana de São Paulo. No entanto, devido ao elevado preço do solo urbano nas áreas mais centrais, essa é a região onde se tem registrado o maior aumento populacional nas últimas décadas.

A Bacia Sedimentar de São Paulo possui $40 \mathrm{~km}$ de largura no sentido norte-sul e aproximadamente $70 \mathrm{~km}$ no sentido leste-oeste. Inserida no Planalto Paulistano, apresenta altitudes que variam de $718 \mathrm{~m}$ a pouco mais de $800 \mathrm{~m}$, configurando planícies, terraços, patamares, colinas, rampas e espigões esculpidos por processos climáticos e pelo trabalho erosivo e depositário do rio Tietê e seus afluentes. As diferenças topográficas da Bacia Sedimentar não ultrapassam muito os $100 \mathrm{~m}$, e isso favoreceu fortemente a ocupação humana. 
A mancha urbana da Grande São Paulo se espalhou e ocupou intensamente a Bacia Sedimentar. Hoje a Região Metropolitana de São Paulo ocupa uma área de aproximadamente $8.000 \mathrm{~km}^{2}$, com densidade de 2.465hab/km² (IBGE, 2013), apresenta intensa impermeabilização e sérios problemas de inundação e abastecimento urbano.

A RMSP está localizada junto a uma faixa de transição climática (230 $21^{\prime} \mathrm{S}$ e $46^{\circ} 44^{\prime} \mathrm{W}$ ) entre os Climas Tropicais Úmidos de Altitude, com período seco definido, e aqueles subtropicais, permanentemente úmidos do Brasil meridional.

De acordo com Monteiro (1973) ao sul desta faixa se apresenta o clima regional em latitude subtropical, permanentemente úmido pela atividade frontal. Mesmo nos anos de atuação mais reduzida do ar polar, a sua participação não é inferior a $40 \%$, podendo elevar-se a $75 \%$ nos anos de maior atividade. Ao norte define-se com maior ou menor intensidade a existência de um período seco, coincidente com o Outono-Inverno, embora isto se abrande no litoral. A menor penetração do ar polar no setor setentrional reduz a quantidade de chuvas frontais de sul para norte e conduz em geral ao bom tempo.

Assim, uma das principais características climáticas desta transição zonal é a alternância das estações (quente e úmida / fria e relativamente mais seca) ao lado de variações bruscas do ritmo e da sucessão dos tipos de tempo. Observam-se situações meteorológicas de intensos aquecimentos bem como de intensos resfriamentos em segmentos temporais de curta duração.

Esta alternância explica, regionalmente, tanto a ocorrência de fortes impactos pluviométricos, como a existência, em determinados anos, de longas sequências de períodos secos. 
Tarifa e Armani (2001) afirmam que esta proximidade com o subtrópico, com forte resfriamento de Outono-Inverno e acompanhada por situações meteorológicas mais secas e estáveis, deve-se, principalmente, à frequência elevada de sistemas anticiclônicos polares, bem como, pelo avanço sobre o continente da alta subtropical.

A urbanização das cidades, que se intensificou com a expansão de parques industriais, implantação de sistema viário e construção de edifícios, provocou alterações nas características climáticas do meio urbano. Em especial nos últimos 30 anos, tem sido registrada uma tendência a ocorrência de excepcionalidades de precipitação no estado de SP e, sobretudo na RMSP.

Ao mesmo tempo, a Região Metropolitana de São Paulo apresenta um dos quadros mais críticos do país no que diz respeito à garantia de água em quantidade e qualidade suficiente para o abastecimento de sua população. A diminuição dos recursos hídricos, associada a uma maior demanda por água potável, já se transformou em uma questão política em muitas localidades.

No caso da RMSP, os indicadores de oferta hídrica são preocupantes mostrando um quadro de escassez que pode se agravar. Assim, esta pesquisa propõe realizar, a partir dos dados climatológicos da série histórica dos Postos Pluviométricos da Região Metropolitana de São Paulo e das Estações Meteorológicas monitoradas pelo INMET, o levantamento dos dados de precipitação a fim de analisar o comportamento das chuvas ao longo dos anos, fazendo um paralelo com o processo de crescimento e desenvolvimento da região, e as possíveis modificações nos elementos do clima impostas por este fenômeno.

Além dos dados de precipitação, será realizado, junto às empresas e órgãos responsáveis pelo abastecimento urbano e monitoramento ambiental, o 
levantamento dos dados referentes à demanda e disponibilidade dos recursos hídricos na RMSP.

Associado à realização da análise estatística da série histórica das Estações Meteorológicas, dos Postos Pluviométricos e dos dados de abastecimento urbano, pretende-se também fazer o levantamento dos processos que deram origem a Região Metropolitana de São Paulo como conhecemos hoje, buscando entender quais foram os eixos de crescimento da área urbana ao longo dos anos, os tipos de uso dados ao solo nas diferentes regiões urbanizadas, o crescimento da indústria e da população, que gera o aumento das pressões sobre o ambiente natural, entre outros aspectos que auxiliam na compreensão do fenômeno urbano e da gravidade dos impactos provocados por ele nos ecossistemas em que se inserem.

Busca-se com esta pesquisa, contribuir para um maior debate sobre o papel do geógrafo no diagnóstico e na avaliação dos impactos ambientais em espaços urbanizados, e na necessidade do profundo planejamento do uso dos recursos naturais em ambientes já fortemente impactados pela urbanização. 


\section{Hipótese de Trabalho:}

Considerando que a RMSP não sofre com longos períodos sem chuva, que seu território localiza-se quase completamente sobre a Bacia Hidrográfica do Alto Tietê, que engloba grandes corpos d'água como o rio Pinheiros e o Tamanduateí (Figura 02), que no trecho que atravessa a mancha urbana metropolitana, o rio Tietê apresenta uma vazão de $82 \mathrm{~m}^{3} / \mathrm{s}$, que seria suficiente para o abastecimento de toda sua população e que a crescente urbanização atuando em cooperação com o aumento de temperatura apresenta potencial para a ocorrência de eventos com precipitação intensa, como é possível considerar que a Região Metropolitana de São Paulo sofre com um preocupante quadro de escassez hídrica para sua população?

A literatura disponível enfatiza dois grandes problemas que afetariam diretamente o abastecimento de água potável na RMSP, a saber; o intenso processo de urbanização e a ocupação desordenada da região, que impõe fortes pressões ao meio ambiente gerando a escassez de alguns recursos naturais, em especial a água, e por consequência fortes conflitos sobre o direito de uso dos mesmos; e a priorização dada pelo governo ao aproveitamento energético dos cursos d'água no início do século XX em detrimento do abastecimento público, que gerou grandes atrasos na implantação de importantes projetos de tratamento e distribuição de água para população. 


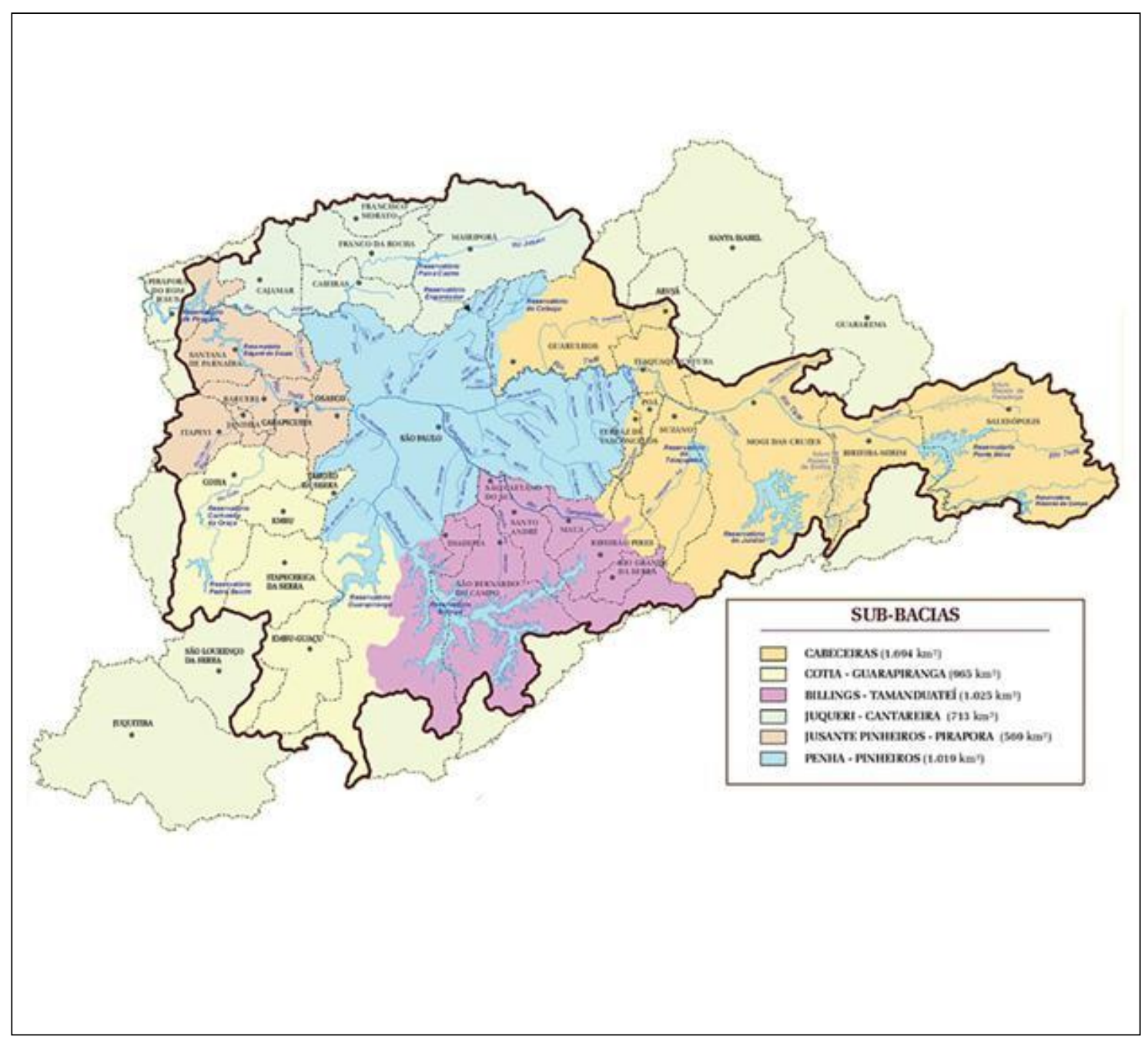

Figura 02: Sub-bacias do Alto Tietê.

Fonte: PDMAT3 - Terceiro Plano Diretor de Macrodrenagem da Bacia do Alto Tietê

A RMSP apresenta hoje um dos quadros mais críticos do país no que diz respeito à garantia do suficiente abastecimento de água em quantidade e qualidade para sua população. A diminuição dos recursos hídricos, associada a uma maior demanda por água potável, já se transformou em uma questão política em muitas localidades. Esse quadro vem se agravando cada vez mais com a constante expansão urbana que gera a ocupação de espaços periféricos e muitas vezes áreas de proteção ambiental (Figura 03), onde se localizam cabeceiras de drenagem e importantes corpos d'água. 


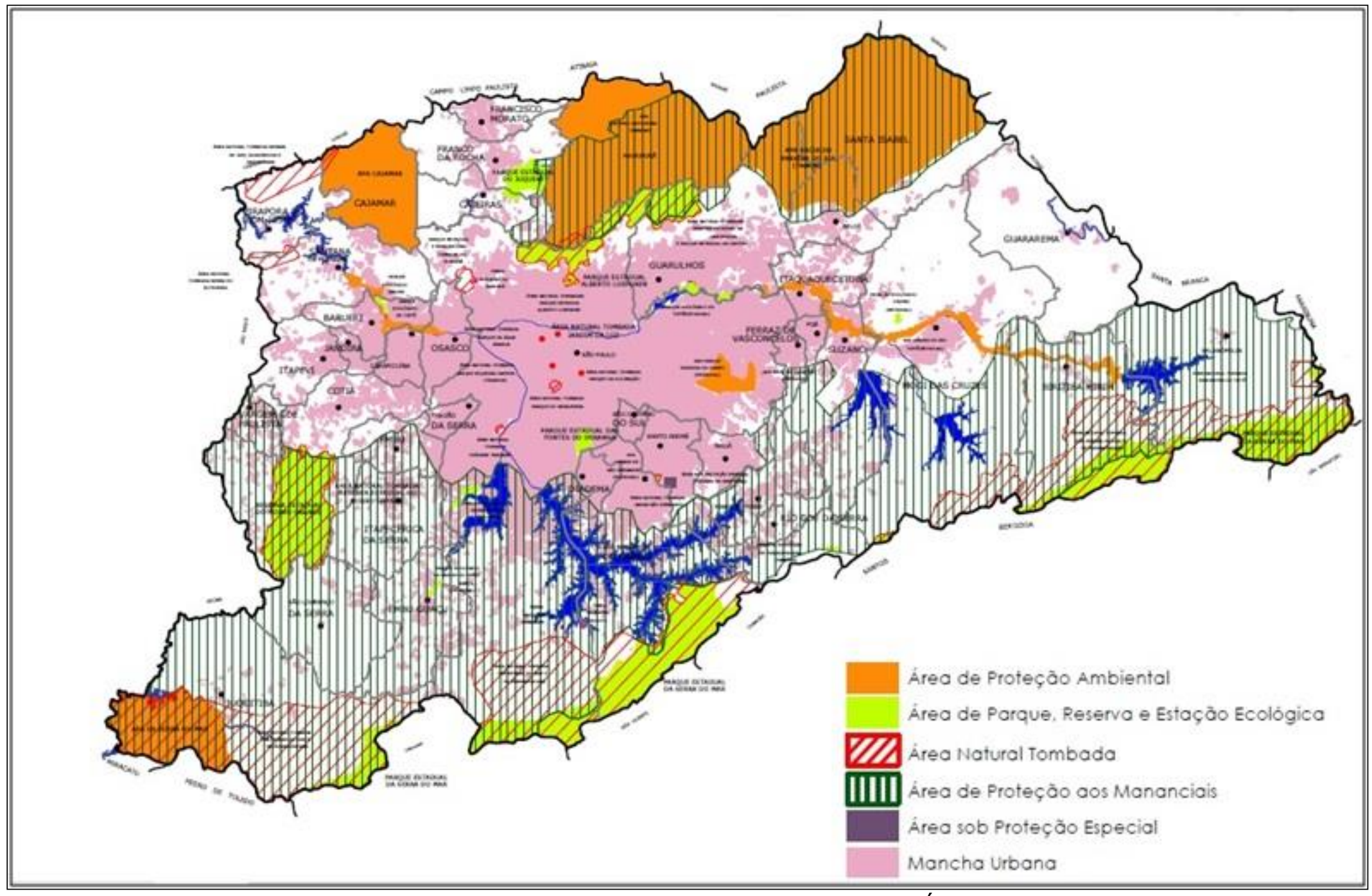

Figura 03: Crescimento da Região Metropolitana de São Paulo e Ocupação de Áreas de Interesse Ambiental - 2010. Fonte: Empresa Paulista de Planejamento Metropolitano - EMPLASA 
Além dos graves impactos ambientais gerados pelo crescimento urbano desordenado, o problema do abastecimento urbano para população da Região Metropolitana de São Paulo pode ser atribuído também à priorização dada à produção energética em detrimento da implantação de projetos de tratamento e distribuição de água potável para população que datam dos primeiros anos do século XX. Grande exemplo disso foi o trabalho encomendado pela empresa canadense Light and Power Co. entre 1911 e 1913, ao então Engenheiro Asa Billings, a fim de projetar um sistema hidrelétrico para Cubatão, cujo esforço traduziu-se na construção da barragem e reservatório Billings em 1927, destinando por conseguinte suas águas para a produção energética na Usina Henry Borden.

Custódio (2012, p. 70) afirma que:

Sem dúvida, a energia elétrica é útil e foi fundamental à instalação de bairros e indústrias na cidade de São Paulo, porém as águas de uma bacia hidrográfica têm usos diversos a serem atendidos. Numa cidade, o principal deles, por motivos de saúde pública, é o abastecimento de água potável à população. Porém, a Light aproveitou e criou inúmeras oportunidades de avançar na apropriação dos recursos hídricos que lhe aprouvessem para geração energética.

O estreito relacionamento que a empresa Light mantinha com o Partido Republicano (PRP), que neste período representava os interesses da oligarquia, era uma condição evidentemente necessária ao seu crescimento. 0 PRP foi único até 1926 e controlava praticamente sozinho a máquina do Estado. Sua política resumia-se na troca de favores e cargos, efetivada através de fraudes eleitorais, corrupção e muitas vezes de violência.

Catullo Branco (1975) diz que em 1930 a companhia Light estava apenas iniciando suas obras em Cubatão e já detinha todo o Alto Tietê, dificultando sempre a destinação das águas da Bacia para fins de abastecimento 
da população, inclusive afirmando que suas águas não eram adequadas para consumo humano mesmo depois de descoberto o processo de cloração.

Como os esgotos lançados na Bacia do Alto Tietê geravam energia barata e abundante, o tratamento foi deixado de lado por várias décadas e a busca de água potável se fez cada vez mais distante da mancha urbana, situação esta, que persiste até os dias de hoje.

As preocupações aumentam porque as bacias vizinhas têm cobrado a água que fornecem à Região, e porque houve abertura do mercado nacional à atuação de empresas privadas nacionais e estrangeiras na prestação de serviços de saneamento básico (água, esgoto, lixo e drenagem), desde 1995, sem nenhuma regulamentação. (CUSTÓDIO, 2012, p.82)

Diante do quadro apresentado, no qual o crescimento urbano desordenado, associado a uma gestão pública corrupta e voltada para o um desenvolvimento econômico descompromissado com a qualidade de vida da população, gerou a inadequada utilização dos recursos hídricos disponíveis e, por consequência um cenário crítico no que diz respeito à garantia de água em quantidade e qualidade suficiente para o abastecimento da RMSP, considera-se necessário discutir também a questão das precipitações, que foi deixada de lado até o momento.

Estudos recentes de Haylock et al . (2006), Dufek e Ambrizzi (2007) e Marengo et al (2009 a, b, c) identificaram tendências para condições mais úmidas no sudeste do Brasil sob a forma de um aumento na frequência de dias com chuva intensa durante os últimos 50 anos, que se estende a toda a região Sudeste e Sul do Brasil.

A crescente urbanização, atuando em sinergia com o aumento de temperatura, apresenta potencial para a ocorrência de eventos com precipitação intensa cada vez mais frequentes, principalmente se considerada a tendência 
para as próximas décadas de um padrão de crescimento urbano na metrópole similar ao atual, no qual a qualidade de vida, o ambiente e o futuro sustentável dos recursos naturais encontram-se em segundo plano.

No entanto, os episódios de maior precipitação não se apresentam de forma bem distribuída ao longo do ano. Sant'Anna Neto (1995) verificou um aumento generalizado de chuvas em todo o Estado de São Paulo com maiores concentrações na primavera/verão, ou seja, o incremento de chuvas não ocorreu uniformemente nas diversas estações do ano, ao contrário, foram maiores de outubro a março. O autor constatou também que o período de estiagem, que antes se concentrava entre os meses de abril a setembro, na maior parte do Estado, tem se prolongado até outubro nas últimas décadas.

Desta forma, a hipótese que se pretende averiguar é a de que o problema não está propriamente na diminuição dos totais anuais de chuva, e sim na falta de um planejamento adequado para enfrentar os novos padrões de chuva, no qual o período de estiagem está se prolongando enquanto nos meses de verão ocorrem precipitações mais intensas.

Os sistemas de abastecimento urbano da Região Metropolitana não estão preparados para atender a população adequadamente, diante dos problemas apresentados, a saber, poluição dos corpos d'água; atrasos na implantação de projetos de saneamento básico; ocupação desordenada de áreas de proteção ambiental, como encostas, margens de rios e áreas de cabeceiras de drenagem e as tendências a mudanças no regime de chuvas em áreas urbanizadas, que se agravarão nas próximas décadas.

É importante verificar se existem projetos que visem à adequação dos antigos sistemas ao novo quadro ambiental que se apresenta e propor soluções para um futuro próximo, no qual os velhos problemas que a população urbana já está cansada de enfrentar, se tornarão ainda mais preocupantes. 


\section{Objetivos:}

\subsection{Objetivos Gerais:}

O objetivo geral desta pesquisa é analisar a relação entre as mudanças no regime de precipitação verificadas na Região Metropolitana de São Paulo nas últimas décadas e os problemas no abastecimento de água para população.

\subsection{Objetivos Específicos:}

- Caracterizar os aspectos físicos da Região Metropolitana de São Paulo e resgatar os processos históricos e de uso e ocupação do solo da área de estudo.

- Analisar estatisticamente os dados das séries históricas de precipitação das estações meteorológicas monitoradas pelo INMET e dos Postos Pluviométricos da RMSP.

- Analisar estatisticamente os dados dos volumes de armazenamento dos mananciais que atendem a Região Metropolitana de São Paulo monitorados pela SABESP.

- Traçar um paralelo entre o processo de crescimento e desenvolvimento da mancha urbana metropolitana, as variações nas precipitações e os problemas de escassez hídrica para a população.

- Contribuir para o diagnóstico e avaliação dos impactos ambientais em espaços urbanizados, recorrendo às relações de dependência entre o Clima, o uso sustentável e consciente dos recursos naturais, em especial a água, e o nível do conforto e do bem-estar dos cidadãos urbanos, além de propor sugestões ao melhor ordenamento territorial da Região Metropolitana de São Paulo. 


\section{Referencial Teórico:}

Esta pesquisa teve como objetivo compreender e avaliar as graves alterações no meio natural geradas pelo crescimento dos núcleos urbanos, em especial na disponibilidade de água em quantidade e qualidade suficientes para o abastecimento das populações que aí residem. Além dos problemas já conhecidos, que se originaram da falta de planejamento adequado e da ocupação de áreas impróprias, fatos comuns às grandes metrópoles, busca-se também compreender as mudanças climáticas que tem sido observadas nos últimos anos, e que afetam diretamente os centros urbanos, causando fenômenos como a mudança do regime de chuvas ao longo do ano.

Dos parâmetros climáticos que sofrem a influência do processo de urbanização, talvez a precipitação seja o que gera mais controvérsias. Muitos métodos já foram empregados para detectar influências urbanas na precipitação e em outros elementos do clima: análises de séries temporais, comparações entre estações rurais e urbanas, em que pese complicadores como as diferenças topográficas; análises de episódios de chuvas mais intensas com a inserção de redes de pluviômetros nas áreas urbanas e arredores ou com utilização de pluviômetros já existentes. Sendo assim, a influência urbana na precipitação apresenta uma série de fatores complicadores para ser demonstrada, visto que, ao contrário da temperatura, requer somente aparatos fixos. Também, a variabilidade com que se verifica a precipitação, por vezes em distâncias muito próximas, é mais um problema a ser discutido.

Assim, foi necessário inicialmente realizar um levantamento da bibliografia que trata dos grandes complexos urbanos como a Região Metropolitana de São Paulo e como estes geram alterações no clima e no meio 
natural. O segundo passo consistiu na seleção de importantes obras que diretamente contribuíram e trouxeram subsídios para o entendimento do tema proposto nesta pesquisa sem, contudo, ter a menor pretensão de esgotar o assunto.

\subsection{As Paisagens Urbanas e a Alteração no Clima}

Atualmente, o que se nota é o rápido aumento dos grandes complexos urbanos, as chamadas megacidades, e as mesmas são o foco recente de estudos relacionados com as questões climáticas.

Megacidades podem ser definidas como áreas metropolitanas com mais de 10 milhões de habitantes, embora essa classificação não possa ser considerada absoluta, pois, segundo Akimoto et al. (2003), as estimativas de população não se baseiam nas mesmas áreas de referência. De acordo com as Nações Unidas, aproximadamente 4,9 bilhões de um total de 8,1 bilhões de habitantes viverão em cidades no ano de 2030 (GURJAR et al ., 2008).

De acordo com Gurjar e Lelieveld (2005), megacidades podem causar grandes emissões de poluentes. A influência da poluição no clima tem escalas locais, regionais e globais, devido a grande quantidade dessas regiões com alto potencial de emissão. O aumento da temperatura média e alterações no regime de chuvas sobre as cidades são impactos decorrentes das emissões antrópicas e de mudanças do uso dos solos, que já são sentidos atualmente.

Aspectos como a rugosidade, as edificações, a geometria do traçado urbano e o adensamento das construções podem ser indicadores determinantes na constituição do clima das cidades, além das funções econômicas desenvolvidas, que respondem por certo nível de degradação e de poluição. A 
temperatura, a umidade e os ventos são influenciados de forma diferenciada, mas, em conjunto representam as condições de existência de um clima urbano.

A evidência de tal alteração no meio ambiente é dada pelo próprio fato de atribuir-se às cidades um clima específico, designado, convencionalmente, de clima urbano. Partindo-se do princípio de que as cidades efetivamente apresentam um clima diferenciado de sua vizinhança rural e que, é um espaço onde se encontra o maior número de pessoas residindo e atuando, há necessidade de levarse em consideração as características da atmosfera daí decorrentes. (DANNI, 1987, p.4)

A definição do que é clima urbano se dá em termos da comparação com seu entorno próximo e das diferenças entre estes.

Possivelmente, a variação na distribuição da temperatura seja a mais significativa alteração gerada pela urbanização. Este elemento do clima das cidades repercute no desempenho das pessoas em suas atividades diárias e também agrava problemas relacionados com a qualidade ambiental.

A umidade relativa do ar, intimamente relacionada à temperatura, é outro elemento de grande importância quando tratamos de clima urbano, pois esta amplia a sensação térmica percebida pelos habitantes urbanos e está diretamente ligada a outros elementos do clima.

O impacto que o rápido processo de urbanização confere às transformações globais é dos mais complexos, pois é nas cidades que os problemas ambientais mais se agravam.

No processo de urbanização, a remoção da cobertura verde e sua substituição por áreas construídas elevam o índice de albedo e, conseqüentemente, a superfície do solo passa a reter menor quantidade de energia, aumentando a refletância. Sabe-se que quanto mais elevado é o volume de energia armazenado, maior é o equilíbrio térmico. (CONTI, 2001, p. 44).

Do ponto de vista teórico e metodológico, a principal referência para os estudos do clima urbano no Brasil é Monteiro, que em 1976 propôs o Sistema Clima Urbano fundamentado na Teoria Geral dos Sistemas. A proposta do 
referido autor baseou-se na percepção humana do ambiente urbanizado, e os resultados visam o planejamento da cidade.

Os três subsistemas do Sistema Clima Urbano foram denominados como: Termodinâmico, Físico-químico, e Hidrodinâmico. Trata-se de um sistema aberto, adaptativo e evolutivo composto pelo clima local e pela cidade.

O canal de percepção Termodinâmico está relacionado ao conforto térmico do ambiente, já o Físico-químico com a análise da qualidade do ar sobre a cidade e o Hidrodinâmico relaciona-se ao impacto meteórico, que nas regiões intertropicais caracteriza-se como impacto pluvial concentrado, sendo este último de maior importância para esta pesquisa.

Este canal possui forte vinculo com a circulação atmosférica regional e seus tipos de tempo especiais (disritmias extremas). As intensas chuvas que atingem 0 ambiente transformado pelo homem facilitam a ocorrência de impactos negativos nas áreas urbanas, que são decorrentes principalmente dos usos dados ao solo nas cidades.

O clima urbano é particular a cada ambiente urbanizado. Para Monteiro (1990, p.8) o clima da cidade pode ser entendido como um sistema aberto e adaptativo, que ao receber energia do ambiente no qual se insere a modifica substancialmente.

As proposições de Monteiro (1976) foram amplamente difundidas e aplicadas no Brasil, e são utilizadas ainda hoje em vários estudos da climatologia urbana.

Como as cidades são dinâmicas, ou seja, tendem a se transformar constantemente, ampliando-se horizontal e verticalmente, provocam com frequência novas e maiores alterações na atmosfera que as recobre. Neste 
sentido, os estudos de clima urbano são imprescindíveis, principalmente nas cidades brasileiras ainda pouco exploradas.

Mesmo as pequenas e médias cidades muitas vezes apresentam características que modificam o clima local e que estão diretamente ligadas às formas de uso do solo.

As cidades de porte médio e pequeno possuem então características geográficas bastante diferenciadas daquelas de grande porte e metropolitanas, e apresentam, portanto, consideráveis facilidades para a identificação de suas paisagens intra-urbanas; estas, previamente identificadas, permitirão uma melhor compreensão da interação sociedade-natureza na construção do clima urbano (MENDONÇA, 2003 p.96)

Para Monteiro (1991, p. 14) a análise climática em cidades médias se torna mais fácil, e ajuda a responder questões, como a partir de que ponto e grau hierárquico uma cidade passa a oferecer condições para a criação de um clima urbano.

Com a expansão territorial urbana o ambiente natural é modificado. Ao construir as cidades os agentes sociais introduzem novos equipamentos e materiais neste ambiente, o que causa modificações no clima local.

De acordo com Danni (1987, p.25), o processo de crescimento urbano impõe um caráter particular à baixa troposfera, produzindo assim, condições atmosféricas locais diferentes das apresentadas nas áreas próximas e dando origem a um clima particular, conhecido como clima urbano.

Sendo o clima um dos elementos de primeira ordem a compor a paisagem geográfica, nas cidades ele é resultante da interação entre as componentes da dinâmica atmosférica zonal, regional e local e os do espaço urbano - rural construído. O clima urbano é então derivado das seguintes principais alterações no ambiente natural: retirada da cobertura vegetal, introdução de novas formas de relevo, concentração de edificações, concentração de equipamentos e pessoas, impermeabilização do solo, canalização do escoamento superficial, rugosidade da superfície, lançamento concentrado e acumulação de partículas e gases na atmosfera e produção de energia artificial. (MENDONÇA, 1994, p.7) 
Os fatores que controlam os diferentes processos na geração do clima urbano são, por um lado, as características do clima regional, no qual a área a ser estudada se insere, que impõe o ritmo e a distribuição temporal dos principais elementos climáticos, e por outro, os fatores relacionados propriamente ao ambiente urbano, que as modificam em escala local.

As transformações produzidas pelo homem na atmosfera urbana afetam o balanço de energia e o balanço hídrico. O espaço urbanizado modifica o albedo, pois os materiais urbanos possuem propriedades radiativas distintas das encontradas em um ambiente não antropizado.

A intensidade e as características destas modificações são diferentes em função das especificidades de cada área urbana, como por exemplo, a densidade de edificações, a rede viária que apresenta, o terreno no qual é construída, a presença ou ausência de áreas verdes, entre outros fatores que tornam cada cidade um ambiente único.

Por alterar o balanço de energia (albedo) a cidade produz diferentes taxas de aquecimento e resfriamento, se comparado à área rural próxima, gerando regimes térmicos distintos e ocasionando a formação do fenômeno "Ilha de Calor".

La isla de calor o isla térmica urbana consiste en que las ciudades suelem ser, especialmente de noche, más cálidas que el medio rural o menos urbanizado que las rodea. Singularmente, el area urbana que presenta temperaturas más elevadas suele coincidir con el centro de las ciudades, allí donde las construcciones y edificios forman un conjunto denso y compacto. (...) (GARCÍA, 1991, p.47)

A preocupação com a ilha de calor e seus efeitos sobre as áreas urbanas, que criam condições de desconforto térmico para população, resultaram em produções como as de Oke $(1978,1982)$ e Lowry (1977), que tinham como 
principal objetivo o esclarecimento dos mecanismos de formação das ilhas de calor.

Segundo Oke (1980), mesmo em localidades muito pequenas, pode ocorrer o fenômeno ilha de calor urbana, e não há uma causa única para sua formação, trata-se de um conjunto de processos que García (1991) resume bem em seu artigo "La intensidad de la 'isla de calor' de Barcelona. Comparacíon con otras ciudades españolas."

a) un mayor almacenamiento de calor durante el día en la ciudad, gracias a las propriedades témicas y caloríficas de los materiales de construccíon urbanos, y su devolucíon a la atmosfera durante la noche;

b) la produccíon de calor antropogénico (calefación, industria, transporte, alumbrado, etc.);

c) la disminuición de la evaporación, debido a la sustitución de la supeficie originaria por un suelo pavimentado y a la eficacia de los sistemas de drenaje urbanos (alcantarillado, etc.);

d) una menor pérdida de calor sensible, debido a la reducción de la velocidad del viento originada por los edificios;

e) un aumento de la absorción de radiación solar, debido a la captura que produce la singular geometría de calles y edificios, que contribuye a un albedo relativamente bajo;

f) una disminución de la pérdida de calor durante la noche por irradiación, debido también a las características geométricas de calles y edificios que reducen el factor de visión del cielo (SVF) y

g) un aumento de la radiación de onda larga que es absorbida y reemitida hacia el suelo por la contaminada atmósfera urbana. (GARCÍA, 1991, p.47)

A intensidade da ilha de calor também pode variar de acordo com as

condições atmosféricas atuantes, com as características do relevo e com a densidade de edificações da área de estudo.

Sob condições atmosféricas ideais, ou seja, em condições de céu claro e com vento calmo, ocorre a máxima intensidade da ilha de calor. Com relevo pouco acidentado, as temperaturas mais altas são observadas nas áreas mais densamente construídas e com pouca vegetação. Horizontalmente há diminuição da temperatura à medida que há a aproximação da zona rural, caracterizada por um gradiente horizontal mais brando, este esquema geral é interrompido por locais quentes e frios associados com densidades de prédios altos e baixos. (...) (AMORIM, 2000, p. 29) 
O fenômeno ilha de calor também está associado ao aumento nas precipitações urbanas. Laurence (1971) conclui que há uma relação entre o ciclo semanal de chuvas nas áreas urbanas influenciadas pelas atividades humanas.

Na mesma linha de pensamento, Landsberg (1981) afirma que a Ilha de Calor contribui com o aumento da precipitação urbana, principalmente quando está associada a outros tipos de tempo, assim como o "efeito obstáculo" (gerado pelas edificações urbanas), que impede a circulação atmosférica devido a aerodinâmica do sitio urbano; e os produtos da poluição, que favorecem a formação de nuvens.

O clima próprio gerado pelos centros urbanos provoca efeitos que são sentidos cada vez mais pela população, pois gera um desconforto térmico, afetando diretamente a vida dos habitantes urbanos.

\subsection{As Pesquisas em Climatologia Pelo Mundo:}

De acordo com García (1991, p.133-141), desde o estabelecimento, a partir do século XVII, de observações meteorológicas realizadas com aparelhos, se produziu um passo decisivo para o futuro nascimento da climatologia urbana. A construção posterior de séries regulares e sistemáticas de observações meteorológicas de algumas cidades permitiram detectar as mudanças produzidas nos elementos climáticos pelo crescimento destas áreas urbanas.

Foi no início da era industrial, em Londres que nasceu o primeiro estudo sobre clima urbano, feito por Luke Howard em 1833.

"A preocupação em estudar o comportamento dos elementos climáticos em superfícies urbanizadas é conhecida desde o século XIX, destacando-se o trabalho pioneiro de Howard (1833) (TARIFFA, 1977, p. 59-80)" 
Neste estudo, Howard analisou observações meteorológicas do período de 1797 à 1831 e relatou as primeiras características do clima de Londres, advertindo sobre a formação do fenômeno da neblina urbana "city fog" e das "ilhas de calor".

Posterior a Howard, Emilien Renou (1815-1902), em um estudo sobre a cidade de Paris, também demonstrou interesse pelo aumento de temperatura detectado nas cidades, consequência da substituição dos materiais naturais e do lançamento de poluentes pelas fábricas.

(...) Emilien Renou (1815-1902), en un trabajo sobre la ciudad de Paris (Renou, 1862), también muestra un gran interes ante el incremento de temperatura observado en la ciudad y trata de encontrar una explicación, sin dejar a un lado sus dudas acerca del problema de la exposición de los termômetros. Sin embargo, en un trabajo ulterior (Renou, 1868), su conclusión es tajante: la diferencia entre el campo y la ciudad es de $1^{\circ} \mathrm{C}$, a la misma altitud. Además manifesta muy certeramente como la diferencia de temperatura durante la noche entre la ciudad y los alrededores, particularmente en el caso de lãs ciudades más grandes, es mayor cuando se produce un tiempo côn unas características meteorológicas determinadas que favorezcan en gran medida el enfriamento por irradiación. (GARCÍA, 1991, p.139)

Já nos últimos anos do século XIX, Hann advertiu sobre o aumento da temperatura nos centros das cidades em relação às áreas mais afastadas, denominando este fenômeno de "standt temperatur".

O termo "urban heat island", ou ilha de calor urbana, foi introduzido na climatologia urbana, já no século XX, por Manley para designar um dos principais fenômenos do clima urbano.

Por volta da década de 1930, ocorreu uma inovação na metodologia para o estudo do clima das cidades, com a introdução da utilização de veículos como ferramenta nos trabalhos de campo, possibilitando a tomada de dados simultânea em diferentes pontos. 
Após a II Guerra Mundial, devido ao rápido crescimento das áreas urbanas, associado ao processo de industrialização, ocorreu o aumento do interesse por parte dos pesquisadores pelo estudo do clima urbano, fazendo com que estas pesquisas se multiplicassem extraordinariamente.

O agravamento dos problemas provocados pela contaminação do ar fizeram com que aumentasse também o interesse pelo estudo dos processos atmosféricos urbanos, gerando uma linha particular de investigação sobre a contaminação da atmosfera das cidades.

Já em meados do século XX, Chandler realizou um estudo sobre 0 clima de Londres, que se tornaria referência para estudos posteriores da climatologia urbana.

Gomez e Garcia afirmaram que "(...) tras la conocida obra de Chandler sobre el clima de Londres (1965), se estableceiram las pautas metodológicas que los estudios del clima urbano siguen en la actualidad" (GOMEZ; GARCIA, 1984, p. 5)

Foi a partir desta década, que se consolidou a utilização da observação direta dos elementos climáticos baseadas em dados obtidos pelas redes meteorológicas, mesmo, levando-se em consideração as limitações impostas pela ausência, em muitas áreas destes dados.

Além das obras de Chandler, mostraram-se também importantes, entre os anos de 1970 e 1980, os trabalhos realizados por Bryson, Landsber, Lowry, Oke, entre outros.

Los estudios más relevantes sobre el tema (Bryson, Chandler, Landsberg, Lowry, etc.) coinciden al afirmar que la ciudad actúa como un factor modificador importante del clima regional y crea unas condiciones medioambientales concretas, definidas como microclima urbano. A ello contribuyen los edificios, el material y trazado de las calles como componentes específicos de la ciudad; el tráfico y la industria, reflejo de las actividades humanas. Se genera así un entramado complejo de interrelaciones mutuas con las connotaciones de un sistema dinámico específico, denominado 
por algunos autores "subsistema climático urbano" (Figueiredo). Las resultantes del mismo se manifiestan en la peculiar distribución del viento de la ciudad como consecuencia del rozamiento con las edificaciones y el encauzamiento por las arterias urbanas; en unos balances hídricos y térmicos diferentes a los existentes en el espacio extraurbano; en la composición de la atmosfera, degradada como consecuencia de la contaminación. (GOMEZ; GARCIA, 1984, p. 6)

Landsberg (1970), também avaliou a questão do aumento de precipitações em áreas urbanas a partir de alguns estudos realizados em cidades da Europa, e conclui que os totais anuais de precipitação urbana estavam, em média, 5 a 10\% maiores do que aqueles próximos a ambientes rurais. O autor baseou sua pesquisa nos resultados obtidos por Schmaussa (1927), Ashworth (1929) e Wiegel (1938).

Ainda na década de 1970 Sanderson e Gorsky (1978), analisando a metrópole de Detroit, detectaram a existência de micro-padrões de precipitação que se modificavam sazonalmente, com os maiores percentuais de aumento no verão. As causas detectadas envolviam o efeito da turbulência resultante da rugosidade da superfície e a convecção térmica (ilha de calor), além da elevada presença de material particulado.

Para Chandler (1965), este aumento da precipitação ocorre devido a três principais fatores que são induzidos pelas atividades provenientes da urbanização, a saber: núcleos adicionais de condensação, turbulência resultante do aumento da rugosidade do sitio e convecção térmica resultante das altas temperaturas encontradas nos centros urbanos.

Segundo Oke (1984), os estudos referentes ao aumento da precipitação em áreas urbanas tropicas, assim como aqueles referentes a climatologia em geral, deveriam receber especial atenção, devido a complexidade climática dessas regiões e a carência de pesquisas se comparado ao pioneirismo das zonas temperadas. 
Também em 1984, Gómez e Garcia realizaram um estudo sobre a ilha de calor em Madrid, encontrando diferenças de até $4^{\circ} \mathrm{C}$ nas médias e $7^{\circ} \mathrm{C}$ nas mínimas. Os autores afirmaram ainda que nas temperaturas máximas as diferenças entre os pontos foram bastante inferiores, tanto no verão quanto no inverno, e que neste caso a distância do ponto em relação ao centro da cidade não foi um fator condicionante.

Outra característica bastante relevante deste trabalho está no fato de os autores encontrarem diferenças térmicas secundárias nas periferias urbanas, o que caracteriza a existência de sub-centros em Madrid.

García (1990, 1991 e 1997) também realizou vários trabalhos sobre o clima urbano, dando ênfase a diversos aspectos de relevância em estudos deste gênero, como a cartografia das ilhas de calor, a realização de um histórico dos estudos de climatologia desde seu surgimento e uma proposta de terminologia castelhana para a climatologia urbana.

García (1990), em seu trabalho "La cartografía del fenómeno de la isla de calor", relacionou um dos principais fenômenos estudados em climatologia, as ilhas de calor, e sua representação cartográfica.

Partindo da definição do que são ilhas de calor, a autora afirmou ser indispensável sua representação cartográfica para o entendimento de sua forma e configuração. Em um segundo momento do trabalho se assinalaram alguns problemas que são detectados ao se representar cartograficamente este fenômeno e foram apontadas possíveis soluções para eles.

Finalmente, a autora apresentou os procedimentos cartográficos mais comumente utilizados na represetação das ilhas de calor, ilustrando com exemplos das cidades de Londres, Vancouver, Madrid e Barcelona. 
Em 1991, a mesma autora (GARCÍA, 1991) realizou um estudo sobre a intensidade da ilha de calor em Barcelona, fazendo uma comparação com outras cidades da Espanha. Os resultados foram obtidos através de registros efetuados ao longo de transectos urbanos e da análise comparativa de dados de dois observatórios, um localizado no centro urbano e outro mais periférico. As conclusões da autora foram de que a ilha de calor de Barcelona mostrou uma intensidade notável, atingindo valores de até $8^{\circ} \mathrm{C}$, mas que estas diferenças apresentaram consonância com as proporções populacionais e com a extensão urbana.

Ainda em 1991, García publicou um estudo detalhado sobre a climatologia urbana ao longo da história, desde a antiguidade até os nossos dias, acrescentando a contribuição do mundo clássico e medieval, além dos estudos pioneiros do século XIX. Para concluir, a autora fixou a atenção no verdadeiro nascimento da climatologia ocorrido no início do século XX e no espetacular desenvolvimento desta ciência nas décadas seguintes.

García (1997), realizando uma proposta de terminologia castelhana para os principais termos da climatologia urbana, afirmou ser esta, uma especialidade bastante jovem na Espanha, que ainda nescessita da criação de termos comuns sobre seus principais conceitos, esforçando-se para que a adoção desta terminologia resulte em clara e fácil compreensão por parte dos usuários. A autora propôs onze termos, com suas denominações originais em inglês, explicando de modo detalhado o porque de tal proposta.

No trabalho de Ganho (1992) intitulado "Insolação e Temperatura em Coimbra: Regimes médios e prováveis na estação meteorológica do IGU", o autor afirma ser uma base necessária aos estudos de climatologia o conhecimento do regime dos elementos climáticos da região pesquisada. 
Nesta perspectiva, Ganho (1992) caracterizou os regimes normais e prováveis de temperatura e insolação na estação meteorológica do Instituto Geofísico da Universidade de Coimbra, a partir da análise de parâmetros de tendência central, de dispersão, e de calendários de probabilidades, de séries seculares das variáveis em estudo.

Hough (1998), em "Naturaleza y ciudad: Planificación urbana y procesos ecológicos" mostrou como, juntando-se os processos urbanos e naturais a nível local, surge uma nova linguagem de desenho para a evlução das cidades. Afirmou, também, em seu trabalho, que o meio ambiente urbano tem sido tratado sobre uma base pouco sistemática, e que temos nos preocupado com a economia sem reparar nos problemas sociais ou do meio ambiente. Em consequência, as soluções para tais problemas tem se mostrado simplistas e fragmentadas.

Lazar e Podesser (1999) analisaram o clima urbano da cidade de Graz, capital da província austríaca da Estíria, a sudoeste da cordilheira principal dos Alpes, utilizando como base, dados sobre o sistema de ventos local, ilhas de calor, além das condições de inversão térmica associadas à propagação de poluentes no ar e a formação de neblina. O trabalho foi realizado em cooperação com o Departamento Regional de Planejamento e Desenvolvimento da Província da Estíria e os resultados do estudo foram demonstrados em cartas de potencialidades e restrições do uso do solo urbano, que tinham como principal objetivo servir de base para o planejamento urbano. Os dados obtidos pelos pesquisadores revelaram que os vales a leste da cidade de Graz tem uma função importante para a renovação do ar fresco nos distritos circunvizinhos, e que as áreas construídas além de gerarem um acréscimo na temperatura de 1 a 3 
Kelvin, diminuem a velocidade do vento devido à altura, localização e estrutura dos edifícios.

Em um importante trabalho sobre o uso do conhecimento do clima no planejamento urbano, Eliasson (2000) afirmou ser um fato conhecido, que a paisagem urbana cria um clima particular que modifica aspectos como o regime de chuvas, a qualidade do ar, o conforto térmico e o consumo de energia, mas que, apesar desse conhecimento, é possível perceber que a questão climática, muitas vezes, tem baixo impacto no processo de planejamento urbano.

A pesquisa contou com o auxílio de um grupo interdisciplinar, formado por climatologistas e planejadores, e teve como principal objetivo investigar se, como e quando o conhecimento sobre o clima é usado no processo de planejamento. A estratégia utilizada por Eliasson (2000) consistiu em um amplo levantamento histórico, associado à utilização de diferentes técnicas de entrevistas, aplicadas aos diversos atores envolvidos no planejamento urbano a nível municipal em três cidades da Suécia. O estudo comprovou que existe sim um interesse por parte dos planejadores na utilização da informação climática em seus projetos, mas que na prática, esse tema nem sempre recebe a devida atenção, talvez por falta de um conhecimento mais aprofundado. É papel dos climatologistas aumentar a conscientização sobre a importância do clima urbano, não só entre os planejadores, mas também entre os decisores e a sociedade em geral.

Utilizando-se do conceito de "conforto térmico" relacionado com a engenharia e projetos de habitação sustentáveis, Oktay (2002) fez uma análise do norte da ilha de Chipre, que se situa no mar Mediterrâneo, entre a costa sul da Anatólia e a costa mediterrânica do Oriente Médio. O autor afirma que, nos projetos urbanos o elemento "clima" deveria ocupar posição de destaque, sendo 
muito importante para a concepção de ambientes confortáveis para a população e ecologicamente sustentáveis, evitando-se, assim, o uso excessivo de recursos paliativos que consomem muita energia. Cada região tem seus próprios padrões climáticos e culturais, que devem ser base para a proposição de soluções em cada caso individual.

Neste contexto, o autor aponta que a arquitetura vernacular, ou regional, é quase sempre climaticamente adequada além de preservar a história e a cultura de um povo, oferecendo, assim, pistas valiosas para os novos projetos de habitação.

Em outro trabalho que trata do planejamento urbano, Svensson e Eliasson (2002) analisam as temperaturas diurnas em áreas construídas. O estudo baseou-se em dados de temperatura coletados durante 18 meses em 18 diferentes pontos da área urbana de Gotemburgo, na Suécia, associados a análises de padrões do uso do solo a partir do Plano Diretor do município, tendo como principal objetivo dar sugestões para implantação de futuros projetos urbanísticos no município.

Svensson e Eliasson (2002) definiram três principais categorias entre as áreas edificadas de Gotemburgo, que foram denominadas de "urbano denso", "multi-familiar" e "casas simples", tendo, cada uma, especificidades que geraram diferenças térmicas ao longo do período. As áreas que compunham a categoria "urbano denso" mostraram-se as mais aquecidas ao longo dos dias de análise, com diferenças de até $8^{\circ} \mathrm{C}$ em relação à periferia próxima, no entanto, as demais categorias apresentaram diferenças similares, ao redor de $4^{\circ} \mathrm{C}$, em relação às áreas periféricas e menos edificadas, mostrando-se, assim, mais adequadas do ponto de vista climático, oferecendo menor desconforto térmico a seus habitantes. 
Em 2003 Koen Steemers, estudioso da arquitetura sustentável, realizou um trabalho que teve como foco as cidades e suas altas demandas de consumo energético, decorrentes da falta de planejamento urbano. Steemers (2003) tomou como exemplo as cidades do Reino Unido e estabeleceu a relação entre a densidade de construções, o fluxo de veículos e o clima temperado com o elevado consumo de energia nestes centros. O trabalho avaliou também as tendências de construção e formas urbanas em cada cidade e apontou como principal caminho a modelagem do urbano em função da diminuição do desconforto térmico imposto aos seus habitantes e de seus efeitos sobre o clima local.

Também preocupados com o conforto térmico nas cidades, Gomez et al (2004), tomando a cidade de Valência como protótipo das demais cidades do Mediterrâneo, destacaram a importância da presença de áreas verdes nos centros urbanos e sua íntima relação com a regulação climática destes ambientes. Os autores utilizaram diferentes índices de conforto, relacionados às condições climatológicas, para estudar cada bairro, que globalmente definiram o comportamento da cidade. Alguns desses índices foram formulados levando-se em consideração as áreas verdes já existentes, e os resultados permitiram definir as superfícies necessárias para que cada bairro pudesse ser considerado teoricamente "confortável". Esta metodologia pode ser útil para os planejadores urbanos na elaboração e distribuição de áreas verdes nas cidades.

Sukopp (2004) avaliou o impacto humano nas vegetações preservadas em Lübeck, na Alemanha, afirmando que as interferências no clima, no solo, no ar e na água são muito maiores e mais danosas nos ambientes urbanos, em relação as zonas rurais. Normalmente a perturbação dos ecossistemas urbanos leva a uma diminuição no número das espécies nativas da região, e apresenta 
um aumento das espécies não nativas. Com um percentual cada vez maior de pessoas vivendo nas cidades, a conservação da biota urbana é de grande importância. As principais interferências impostas pelo homem incluem movimentos de terra durante a construção de ruas, a compactação do solo pelo pisoteio e o trânsito de veículos, a eutrofização e o aumento dos valores de pH no solo.

A presença de vegetação nas áreas urbanas funciona como um importante regulador térmico para esses ambientes, minimizando os efeitos gerados pelo excessivo processo de impermeabilização nas cidades.

Solecki et al (2005) estudaram a possibilidade de mitigação do efeito da ilha de calor urbana em Nova Jersey, nos Estados Unidos, através do aumento da cobertura vegetal urbana e da implantação de materiais que podem reduzir os riscos biofísicos nas cidades, que incluem o stress térmico relacionado a elevadas temperaturas e a poluição do ar, que afeta diretamente a saúde da população. Foi realizada uma modelagem baseada em GIS para estimar os potenciais benefícios das áreas verdes e da utilização de telhados reflexivos como estratégias de mitigação do efeito "ilha de calor urbana" para áreas ao redor de Newark e Camden, no estado de Nova Jersey. A análise mostrou que a vegetação urbana pode reduzir os riscos a saúde associados com o efeito das ilhas de calor, pela remoção de poluentes do ar. Os resultados mostraram também, que a implantação de áreas verdes é uma forma eficaz e economicamente viável de reduzir o consumo de energia com equipamentos como o ar condicionado.

Pauleit et al (2005) propuseram a modelagem dos impactos ambientais, gerados pelo uso do solo na construção das cidades, utilizando como exemplo 11 áreas residenciais em Merseyside, no Reino Unido. O processo de 
modelagem consistiu na utilização de fotografias aéreas tomadas em 1975 e posteriormente em 2000 para que os autores pudessem verificar a alteração de três importantes parâmetros ambientais (temperatura da superfície, escoamento da chuva e diversidade de áreas verdes), e relacioná-los com o estatuto socioeconômico das áreas, medido por índices de carências múltiplas.

As comparações realizadas por Pauleit, Ennos, Golding (2005) revelaram uma perda de áreas verdes em todos os 11 casos analisados. As áreas de baixa densidade populacional apresentaram as maiores perdas, no entanto, o índice de perda foi significativo também nos espaços já densamente urbanizados. Os resultados enfatizaram a necessidade de uma revisão crítica de conceitos como a densificação urbana e a importância das áreas verdes nas cidades.

\subsection{As Pesquisas de Climatologia no Brasil}

Com o rápido desenvolvimento dos estudos sobre o clima das cidades pelo mundo, cresceu também o interesse por parte dos pesquisadores brasileiros em entender os fenômenos gerados pelos centros urbanos, que atuam como transformadores do clima local.

Em 1976, Monteiro propôs, fundamentando seus estudos na Teoria Geral dos Sistemas, o Sistema Clima Urbano, que é uma análise baseada na percepção humana do ambiente urbanizado, e cujos resultados visam o planejamento da cidade.

Para a melhor compreensão do clima urbano, Monteiro (1976), propôs uma discussão mais detalhada sobre as questões escalares, afirmando que "[...] o clima se posiciona no espaço concreto, tridimensional da superfície terrestre 
através daquilo que Ihe constitui o arcabouço - as formas do terreno" (MONTEIRO, 1976, p.104).

Não é possível entender o clima urbano sem inseri-lo em uma escala maior de análise. "O espaço urbanizado, que se identifica a partir do sítio, constitui o núcleo do sistema que mantém relações íntimas com o ambiente regional imediato em que se insere" (MONTEIRO, 1976, p. 96).

O entendimento do local não é suficiente para sua total compreensão, é preciso relacioná-lo com o clima regional, pois é neste que se dá a atuação dos sistemas meteorológicos que influem diretamente nos fenômenos locais.

O clima local se insere em climas sub-regionais e sazonais, assim como pode ser subdividido até os microclimas. A cidade tanto se integra em níveis superiores como se divide em setores, bairro, ruas, casas, ambientes internos etc. As divisões do ponto de vista sistêmico são inconsequentes, importando predominantemente as relações entre as diferentes partes em que se compõe ou decompõe o sistema para o desenvolvimento das funções organizadoras. (MONTEIRO, 1976, p. 96).

Em 1977, Tarifa estudou as características termo-higrométricas no município de São José dos Campos, onde comparou dados coletados em áreas rurais e urbanas, encontrando grandes variações nas temperaturas, principalmente no período diurno, constatando, assim, a presença da Ilha de Calor sobre o núcleo urbano do município.

Analisando a Região Metropolitana de São Paulo, Lombardo (1985) também detectou forte presença de Ilha de Calor urbana, principalmente nas primeiras horas do período noturno. Em seu estudo Lombardo (1985) levou em consideração, principalmente, a qualidade ambiental e a influência do crescimento urbano sobre ela.

Em 1990 Monteiro publicou três artigos com o objetivo de auxiliar nas pesquisas do clima urbano, um deles inclusive intitulado "Por um Suporte Teórico e Prático para Estimular Estudos Geográficos de Clima Urbano" (MONTEIRO, 
1990), onde afirmou que para se realizar o estudo do clima urbano é necessário que se realizem análises meteorológicas sobre as cidades, considerando-as como "fatos geográficos", definindo, assim, uma estratégia de abordagem para se conduzir as pesquisas. Afirmou, também, que é preciso conhecer todos os aspectos relativos à cidade, inclusive a cultura da sociedade em que ela está inserida, para um melhor entendimento de suas formas de ocupação e das atividades realizadas em seu interior.

No mesmo ano, Monteiro e Sezerino (1990), complementando os estudos já realizados, introduziram o conceito de campo térmico, tomando por base as análises realizadas na cidade de Florianópolis, onde, com a utilização de miniabrigos munidos de psicrômetros instalados em pontos fixos, característicos de ambientes bem diferenciados, tanto em altitude como em número de edificações, dentro do núcleo urbano detectaram fortes diferenças na temperatura nos vários horários analisados.

Em 1994, baseando seus estudos na cidade de Londrina, localizada no estado do Paraná, Mendonça identificou quinze diferentes "ambientes climáticos". Realizando coletas nos meses de verão e inverno detectou a presença de fortes Ilhas de Calor urbana, com valores muitas vezes superiores a $10^{\circ} \mathrm{C}$.

Barrios e Sant'Anna Neto (1996) estudando o Extremo Oeste Paulista, observaram que cerca de $80 \%$ dos eventos climáticos extremos estão vinculados aos episódios de chuvas intensas ou prolongadas, muitas vezes acompanhadas de rajadas de ventos e chuvas de granizo. Com isso, é possível observar que a precipitação torna-se um elemento importante nas áreas urbanas, pois esta provoca fortes impactos ambientais devido a sua intensidade e frequência.

De acordo com Monteiro (2003) este "[...] problema é de especial importância para nós, no Brasil, já que dificilmente há um ano que, em 
diferentes regiões, não haja uma ou algumas cidades violentamente atacadas [...]" (MONTEIRO, 2003, p. 55) pelas precipitações.

Pitton (1997) fez um balanço da forte influência dos centros urbanos no clima, e afirmou que o organismo urbano constitui um dos principais reflexos da atuação do homem sobre o meio natural.

Sua pesquisa se concentrou no campo térmico, pois considerou que é a partir deste que se produzem as características climáticas da cidade, afirmando que nos estudos de clima urbano o enfoque sistêmico é necessário e útil. Retomou a ideia de Monteiro (1976) que abordou o clima urbano como "sistema singular" que compreende o fato natural e o fato social.

Amorim (2000) realizou um estudo sobre os efeitos de uma cidade (Presidente Prudente - SP) de porte médio, localizada próxima ao Trópico de Capricórnio e a uma distância aproximada de $600 \mathrm{~km}$ do oceano.

O município de Presidente Prudente tem sua área urbana situada sobre um espigão divisor de águas, com altitudes que variam de 375 metros a pouco mais de 480 metros. A autora afirmou que para o entendimento do clima urbano do município foi preciso levar em consideração fatores como o tipo de uso e ocupação do solo, apontou também a importância da presença de áreas verdes e arborização nas calçadas para amenizar as temperaturas e contribuir para o balanço de umidade no interior do núcleo urbano.

Realizando uma análise temporal e espacial do município, Amorim (2000) identificou a presença de Ilha de Calor urbana durante todo o dia, apresentando maiores magnitudes ao amanhecer e no pôr do sol.

No ano de 2002 Sant'Anna Neto organizou em uma publicação estudos de algumas cidades brasileiras como São Luís no estado do Maranhão, Aracajú 
em Sergipe, Campo Grande em Mato Grosso do Sul, Petrópolis no Rio de Janeiro, Sorocaba e Penápolis, em São Pulo.

Araújo e Sant'Anna Neto (2002) analisaram o processo de urbanização e as formas de ocupação no município de São Luís, que, mesmo sendo uma cidade localizada bem próximo a zona equatorial, recebendo assim insolação mais direta, também influencia no clima local, devido as formas de ocupação do sítio e as atividades realizadas em seu interior.

Pinto (2002) em estudo sobre o clima local do município de Aracajú, capital do estado de Sergipe, afirmou que a cidade pode ser considerada privilegiada pelas chuvas, se comparada aos demais municípios do território nordestino, pois possui uma variabilidade inferior aos demais, comportamento característico das localidades litorâneas. No entanto, Pinto (2002) afirmou que a elevada média pluviométrica não implica necessariamente em uma boa distribuição cronológica dessa precipitação, e que o município também enfrenta dificuldades com relação as chuvas.

Sobre a cidade de Campo Grande, Anunciação e Sant'Anna Neto (2002), concluíram que a presença de Ilhas de Calor e Ilhas de Frescor independem da estação do ano, sendo presentes tanto no verão como no inverno, períodos estes, analisados no estudo.

Hack (2002) focou seu estudo no clima urbano da cidade de Petrópolis, cidade localizada a 895 metros de altitude, fazendo parte da Região Serrana do Estado do Rio de Janeiro.

Com seu estudo, Hack (2002), concluiu que por sua altitude elevada, Petrópolis apresenta temperaturas mais amenas na maior parte do ano, e foi através da análise climatológica de 1931 a 1995 que pode verificar que o 
município não apresenta estação seca, elegendo o ano de 1988 como o mais chuvoso da série.

Em estudo sobre o município de Sorocaba, Tavares (2002), buscou definir padrões climáticos decorrentes dos processos de urbanização, relacionando os aspectos regionais, locais e urbanos em sua análise.

Tavares (2002) baseou seus estudos na diferenciação diária dos elementos climáticos, principalmente a temperatura, analisando os anos de 1987, 1988, 1989 e o primeiro semestre de 1990.

Silva et al (2002), estudaram o clima urbano de Penápolis em um episódio de inverno, onde puderam perceber a presença do fenômeno Ilha de Calor principalmente no período noturno, apresentando picos no horário das $21 \mathrm{~h}$.

Viana (2006), em estudo sobre o clima urbano de Teodoro Sampaio, definiu sete pontos de coleta de dados que abrangiam bairros com características de uso e ocupação do solo bem distintos. Durante a pesquisa a autora realizou transectos no período da noite, entre $20 \mathrm{~h} 30$ e $21 \mathrm{~h}$ e as leituras dos pontos fixos foram feitas nos horários das $7 \mathrm{~h}, 9 \mathrm{~h}, 15 \mathrm{~h}$ e $21 \mathrm{~h}$ em treze dias do mês de janeiro de 2005 e oito dias do mês de julho do mesmo ano.

Como resultado, Viana (2006) encontrou um padrão. As áreas urbanas densamente construídas, com pavimentação e pouca vegetação apresentaram-se mais aquecidas e com umidade relativa menor que as adjacentes, que contam com menor densidade de construções e ruas sem pavimentação e a área rural, que dentre todas se apresentou mais fresca e úmida.

Em 2009 Andreoti realizou a comparação do microclima entre dois imóveis nos municípios de São Paulo e São Roque, que possuem grandes diferenças em função do uso do solo, também relacionadas com a densidade populacional de cada centro. O autor instalou registradores de temperatura e 
umidade relativa do ar nos dois pontos, e os dados levantados foram submetidos a tratamentos estatísticos a fim de possibilitar a comparação. A partir desses resultados Andreoti (2009) identificou valores de temperatura maiores e umidade relativa inferior no imóvel localizado em São Paulo.

Pinheiro (2012) realizou a análise das chuvas na cidade de Bauru, a fim de avaliar se as mudanças no regime de precipitação, causados pela urbanização, influenciaram em questões como o aumento das enchentes, e encontrou uma forte correlação entre os eventos extremos e os impactos ao ambiente urbano, mesmo verificando que houve uma redução de tais eventos na década de 2000.

Sobre a cidade de São Paulo, Silva Dias et al . (2013) analisaram uma série temporal de precipitação do período entre 1933 e 2010 e encontraram tendências positivas na evolução de chuvas intensas em São Paulo. Índices climáticos foram responsáveis pela explicação de $85 \%$ do aumento na frequência de extremos durante o período seco. Tal fato indica que outros fatores como o crescimento da influência da ilha de calor urbana e o efeito da poluição atmosférica na microfísica das nuvens devem ser considerados.

\subsection{As Pesquisas sobre a Região Metropolitana de São Paulo}

O Brasil é o país em desenvolvimento mais urbano do mundo, onde mesmo pequenas e médias cidades no interior estão se urbanizando, sem o devido cuidado com a ocupação ordenada do solo urbano. As variações térmicas observadas entre as zonas urbanas e rurais são altas, tendo como causas principais a substituição da vegetação natural por materiais como concreto e asfalto, adensamento das edificações entre outras. (LOMBARDO, 1985) 
A evolução do ambiente urbano é o resultado de um vasto conjunto de fatores sociais, tecnológicos, artísticos, políticos e econômicos em constante interação ao longo do tempo. A questão urbana é uma problemática síntese de vários aspectos do trabalho dos homens.

Neste contexto enquadra-se a Região Metropolitana de São Paulo, caracterizada pela forte urbanização e pela falta de um planejamento adequado, que tal como outras regiões do planeta, enfrenta uma série de desafios relacionados ao meio ambiente e em especial às mudanças climáticas.

Os aspectos negativos das aglomerações urbanas, tais como as questões de saúde pública, de fornecimento de transporte adequado, de destinação dos resíduos, de abastecimento hídrico, entre outros, crescem exponencialmente com o tamanho das metrópoles. Inevitavelmente, cresce também o reconhecimento de que a base de recursos naturais de que os seres humanos dispõem é limitada e, em muitos casos, exaurível. O meio ambiente passou a exigir atenção e impõe-se como uma das grandes questões da humanidade.

As áreas urbanas são o foco de diversos estudos relacionados com as questões ambientais e climáticas, em especial com as alterações nos regimes de precipitação decorrentes de processos de crescimento e desenvolvimento populacional. Tendências positivas no número de dias com chuva intensa e muito intensa, concentrada em curtos períodos de tempo e na quantidade de eventos chuvosos que podem gerar enchentes e deslizamentos de terra em áreas de encosta, têm sido detectadas desde a década de 1990 (XAVIER et al 1994, CARVALHO et al 2002, MARENGO et al 2009c, HAYLOCK et al 2006, ALEXANDER et al 2007). 
Xavier et al (1994) analisaram a variabilidade das precipitações na RMSP de 1933-1986, apresentando de fato um aumento na intensidade da chuva em fevereiro e maio. Estudos recentes de Haylock et al . (2006), Dufek e Ambrizzi (2007) e Marengo et al (2009 a, b, c) identificaram tendências para condições mais úmidas no sudeste do Brasil sob a forma de um aumento na intensidade e frequência de dias com chuva forte durante os últimos 50 anos, que se estende a toda região Sudeste e Sul do Brasil.

A análise de modelos da expansão territorial estimada para a RMSP em 2030 mostra que os cenários de risco e respectivas vulnerabilidades para processos da dinâmica superficial deflagrados por eventos meteorológicos intensos, como enchentes, inundações e escorregamentos, deverão ficar mais críticos.

Tais estimativas futuras são baseadas na perspectiva de que, seguindo os padrões históricos de crescimento e ocupação da RMSP, uma parcela significativa da população ocupará assentamentos de padrões construtivos precários em terrenos de várzea e de encostas íngremes de morros nas periferias das cidades, e que uma parcela significativa da população se tornará cada vez mais exposta a riscos de doenças respiratórias e por contaminação através da água.

O processo de urbanização é umas das principais interferências da mudança na natureza da superfície do solo e nas propriedades atmosféricas presentes na Camada Limite Urbana (UCL). Essa transformação resulta em mudanças dos ventos regionais, na geometria da radiação solar e da insolação e emissão de poluentes, propiciando as temperaturas mais elevadas nas zonas urbanas consolidadas em comparação com as zonas periféricas ou rurais. (LOMBARDO, 1985). 
O panorama ambiental atual da RMSP foi tratado por Bruna et al (2004), que apresentou o conceito de Ecologia Urbana e discorreu sobre suas implicações em regiões metropolitanas. Sobre o abastecimento público Grisotto et al (2004), Kondo et al (2004) e Miguel et al (2004) abordaram questões como mananciais, tratamento das águas residuárias domésticas e industriais, drenagem urbana em grandes áreas metropolitanas e a destinação do lodo dos esgotos.

Segundo o IBGE, a RMSP é a grande metrópole nacional, apresentando uma projeção que se estende a todo o território do país, confirmando a sua primazia urbana, principalmente pela sua produção material e intelectual (SANTOS, 1994). Não à toa, a região tem sido objeto de diversos estudos, pois entender a urbanização brasileira sem passar pela experiência da RMSP é quase impossível. Ela é, por excelência, o local privilegiado de inúmeros e simultâneos desafios: atração e expulsão populacional; crescimento econômico e pobreza; movimentos sociais precursores; vulnerabilidades sociais, econômicas e ambientais (BÓGUS; PASTERNAK, 2009).

Portanto, uma análise das características físicas, espaciais, demográficas e ambientais da metrópole permitiria identificar, em um segundo momento de reflexão, os processos que conduzem à vulnerabilidade da população. De certa maneira, por trás dessa aparência desordenada de crescimento metropolitano residem lógicas das mais diversas (KOWARICK, 1993) e que conduziram à estruturação de um espaço intraurbano marcado por essas desigualdades e riscos ambientais.

Para Bógus e Pasternak (2009), algumas fases do processo de expansão da RMSP podem ser identificadas. A primeira fase, de 1930 a 1950, aproximadamente, pode ser denominada de pré-metropolitana e propiciou 
condições estruturantes para a integração de áreas urbanas entre os municípios da região, particularmente ao longo dos eixos ferroviários (Santos-Jundiaí, Sorocabana e Central do Brasil), iniciando um processo que viria a consolidar algumas cidades-dormitório.

Em um segundo momento, até a década de 1960, novos equipamentos de infraestrutura consolidaram tais eixos ferroviários e ampliaram sua extensão, com a incorporação do sistema rodoviário com novos espaços de localização industrial. Fato que contribuiu fortemente para a atração mais intensa de grandes contingentes populacionais para a região. De 1960 a 1980, uma terceira fase da RMSP surge através da concentração de novas localizações industriais na Região do $A B C$, fortalecendo a vinculação entre São Paulo e a Baixada Santista, a partir da Rodovia Anchieta (BOGUS; PASTERNAK, 2009).

Enfim, a última fase, que se estende até os dias de hoje, compreende um processo de reestruturação produtiva (HARVEY, 2008), que é um processo mundial associado à globalização e evidencia na RMSP uma característica de prestação de serviços e da financeirização dos investimentos, antes industriais. Assim, o ritmo do crescimento populacional, a forma da expansão urbana e os conflitos socioambientais se fundem em uma metrópole complexa, densa e multissetorial, em que os desafios colocados pelas mudanças climáticas agravarão as carências e as vulnerabilidades seculares em um cenário de grandes transformações também no âmbito dos modos de produção e dos modos de vida e padrões de consumo.

Para Faria (1991), muitas vezes confundimos o próprio processo de urbanização com os processos de mudança social derivados da constituição de uma sociedade urbana, pois no caso da RMSP, esses processos são praticamente indissociáveis. Mas não basta preconizar o processo histórico para entender as 
vulnerabilidades socioambientais acumuladas no espaço. É preciso entender também como o espaço interfere na vida cotidiana.

Nesse sentido, há que se distinguir o crescimento urbano da RMSP, a partir da sua evolução populacional, da apropriação física dos espaços da metrópole. Afinal, no período mais recente, a metrópole antes compacta, densa, dicotômica (centro-periferia) e polarizadora passou a apresentar sinais marcantes de um novo padrão: disperso, fragmentado, heterogêneo e multifuncional (MARTINE, 2007; UNFPA, 2007; OJIMA, 2007).

Dentro desse contexto, desde os anos 1980, o Estado de São Paulo passou por um processo de desconcentração da indústria a partir da metrópole paulistana, em direção aos municípios do interior, devido ao surgimento de novos pólos de desenvolvimento econômico nessas regiões (BAENINGER, 2004; CANO, 1988; PACHECO, 1998). Além disso, a RMSP como um todo passou a apresentar um ritmo de crescimento populacional moderado (CUSTÓDIO, 2012), bem próximo à média nacional nos anos 1990 (1,6\% a.a.). Mas internamente, a redistribuição da população dentro do espaço metropolitano se alterou significativamente e marcou o início do século XXI com uma nova dinâmica.

Segundo Torres (2004), as taxas de crescimento populacional das áreas mais afastadas do centro correspondem a praticamente todo o crescimento da RMSP na década de 1990. Assim, se não considerássemos essa parcela da metrópole, o crescimento populacional seria praticamente nulo. Entretanto, essa reorganização do espaço, que tem sido tendência em outras regiões metropolitanas do Brasil e do mundo, não é homogênea. A tradicional visão centro-periferia merece ser relativizada na medida em que um conjunto expressivo de áreas urbanas afastadas do centro e predominantemente pobres apresenta crescimento populacional elevado, ao mesmo tempo em que outras 
áreas, também pobres e afastadas, apresentam crescimento muito baixo (a periferia consolidada).

\subsection{A Água e a Gestão dos Recursos Hídricos.}

A água é um recurso essencial para o surgimento da vida e para sua manutenção. Como principais usos podemos destacar: o abastecimento público e industrial, agricultura, dessedentação de animais, geração de energia elétrica, navegação, higiene, alimentação, limpeza e lazer.

Miller Júnior (2006) afirma que mesmo sendo um recurso de inestimável importância, a água ainda não recebe a devida atenção da sociedade, e que o valor cobrado pelo seu uso é irrisório, favorecendo o consumo irracional por parte da população.

O nosso planeta possui cerca de 1.386 milhões de $\mathrm{km}^{3}$ de água (SHIKLOMANOV, 1999). Destes, apenas $2,5 \%$ são de água doce, sendo aproximadamente $1,7 \%$ nas calotas polares e glaciais, $0,8 \%$ nos depósitos subterrâneos profundos e apenas 0,0075\% em fontes de fácil acesso (UNESCO, 2006). O Brasil tem posição privilegiada no mundo, em relação à disponibilidade de recursos hídricos. A vazão média anual dos rios em território brasileiro é de cerca de $180 \mathrm{mil} \mathrm{m} 3 / \mathrm{s}$. Esse valor corresponde a aproximadamente $12 \%$ da disponibilidade mundial de recursos hídricos, que é de 1,5 milhões de $\mathrm{m}^{3} / \mathrm{s}$ (SHIKLOMANOV et al., 2000). Se forem levadas em conta as vazões oriundas de territórios estrangeiros que ingressam ao país (Amazônica: $86.321 \mathrm{mil} \mathrm{m3/s}$; Uruguai: 878 m3/s e Paraguai: 595 m3/s), a vazão média total atinge valores da ordem de $267 \mathrm{mil} \mathrm{m} 3 / \mathrm{s}$ (18\% da disponibilidade mundial). 
No entanto, a disponibilidade de água no Brasil depende em grande parte do clima. O ciclo anual das chuvas e de vazões no país varia entre bacias, e de fato a variabilidade interanual do clima, associada aos fenômenos de El Niño, La Niña, ou à variabilidade na temperatura da superfície do mar do Atlântico Tropical e Sul podem gerar anomalias climáticas, que produzem grandes secas, como em 1877, 1983 e 1998 no Nordeste, 2004-2006 no Sul do Brasil, 2001 no Centro-Oeste e Sudeste, e em 1926, 1983, 1998 e 2005 na Amazônia (MARENGO \& SILVA DIAS, 2006; MARENGO, 2007; MARENGO et al., 2008 a, b).

A crescente demanda de água doce e a poluição fazem com que este recurso e sua disponibilidade se encontrem em níveis preocupantes. De acordo com a Organização das Nações Unidas, em 2005, 1,1 bilhão de pessoas não dispunha de água potável segura para uso doméstico e 2,6 bilhões não tinham acesso a saneamento básico (WHO, UNICEF, 2005).

Além do aumento da população mundial há outro agravante com relação à demanda de água, o consumo por habitante vem crescendo ao longo dos anos. Segundo o IBGE (2004) o consumo de água no Brasil aumentou em $30 \%$ de 1989 a 2000, um crescimento superior ao da população. O volume distribuído passou de 200 para 260 litros diários por habitante. Esse cenário se torna ainda mais preocupante nas áreas urbanas, pois a elevada demanda por água nas cidades limita a atividade econômica e retarda o desenvolvimento.

Muitas cidades brasileiras já enfrentam desafios relacionados à água, onde o abastecimento público se encontra ameaçado por problemas tanto com sua quantidade quanto com sua qualidade.

Hespanhol (2008) discute o paradigma da gestão de recursos hídricos e comenta que a Conferência Mundial das Nações Unidas para o Meio Ambiente realizada em Dublin no ano de 1992 propôs quatro princípios para a gestão dos 
recursos hídricos do século XXI, sendo dois deles: "a água é um recurso finito e vulnerável, essencial para a manutenção da vida, do desenvolvimento e do meio ambiente" e "a água tem valor econômico, para todos os seus usos e deve ser considerada como um bem econômico $[\ldots]^{\prime \prime}$.

Considerando as contribuições desta conferência, nota-se que há uma indicação de que na gestão dos recursos hídricos deve considerar-se o uso parcimonioso da água e sua conotação de "commodity". Os reflexos da Conferência Mundial das Nações Unidas para o Meio Ambiente na legislação brasileira se traduziram pela:

[...] promulgação de uma ampla legislação, entre as quais a Lei $n$. 9.433 (janeiro de 1997), que instituiu a Política Nacional de Recursos Hídricos e definiu a estrutura jurídico administrativa do Sistema Nacional de Recursos Hídricos, a Lei n. 9.984 (julho de 2000) que criou a Agência Nacional de Águas, e a Resolução Conama n.16 (maio de 2001) que estabeleceu critérios gerais para a outorga de direito de uso de recursos hídricos (HESPANHOL, 2008, p.131).

O Plano Nacional de Recursos Hídricos - PNRH (Lei no. 9433/97), colabora no gerenciamento hídrico a fim de promover uma maior sustentabilidade da água como bem comum. Com o contínuo aumento da demanda, diminuição da oferta, e a água desempenhando um papel fundamental nas relações econômicas, políticas, sociais e ambientais, se faz necessária a busca por novas técnicas de manejo e gestão para garantir o uso presente e futuro.

A outorga da água instituiu a cobrança pelo uso dos recursos hídricos, o que, segundo Hespanhol (2008, p.131), "[...] modificou substancialmente as bases operacionais e econômicas do uso da água". Essa cobrança, num primeiro momento, foi criticada por alguns setores, mas representou uma via de proteção ambiental, reduzindo os eventos de descarga de efluentes em corpos hídricos (HESPANHOL, 2008). 
Embora não se negue a importância do mecanismo legal e institucional do sistema de outorga, esse instrumento não se mostrou suficiente para equilibrar a demanda e oferta da água, principalmente em localidades conturbadas, como a RMSP, nas quais as perspectivas são de crescimento demográfico e da atividade econômica, e a disponibilidade da água é colocada à prova (HESPANHOL, 2008).

Neste contexto a Região Metropolitana de São Paulo merece destaque quanto à preocupação devido à escassez hídrica que vem sofrendo, classificandose como uma das mais críticas do país. Devido ao rápido crescimento populacional ao longo dos anos, a oferta desse recurso (oferta hídrica) fica cada vez mais difícil de ser administrada.

A oferta hídrica é a quantidade de água disponível por habitante em uma unidade territorial. Ela pode ser obtida pela soma da água renovada com o estoque hídrico (vazão média dos rios ou volume conhecido nos aquíferos), cujo resultado deve ser dividido pela população da unidade territorial. Existem duas formas aceitas na literatura que procuram avaliar a oferta hídrica: a escassez hídrica e o estresse hídrico (IBIDEM, 2008).

A primeira pode ser física, quando o volume de água é insuficiente para abastecer a população e decorre, em geral, dos baixos índices de pluviosidade ou do uso muito acima da oferta hídrica. A segunda ocorre quando não há recursos financeiros para captar e trazer água de outros pontos até o local de consumo.

O estresse hídrico é "resultado da relação entre o total de água utilizado anualmente e a diferença entre a pluviosidade e a evaporação (a água renovada) que ocorrem em uma unidade territorial" (IBIDEM, 2008). 
Em média, as chuvas da RMSP atingem $1.400 \mathrm{~mm}$ anuais (COMITÊ DE BACIA HIDROGRÁFICA DO ALTO TIETÊ, 2002). Entretanto, as chuvas não ocorrem de modo uniforme e chegam a quase $3.000 \mathrm{~mm}$ junto à Serra do Mar (FUSP, 2009). Por meio desse indicador, não é possível afirmar que São Paulo está em regime de escassez hídrica, pois não basta chover, é preciso ter condições de armazenamento da água para depois tratá-la e distribuí-la.

Torna-se necessária a gestão dos recursos hídricos urbanos de maneira integrada e participativa para que se chegue a soluções sustentáveis e viáveis. E dentro da esfera da gestão dos recursos hídricos urbanos se encontra a gestão de águas pluviais em áreas urbanas que envolve tanto a disponibilidade hídrica, quanto o setor de drenagem urbana.

A gestão das águas pluviais compreende o monitoramento das chuvas, entendimento do ciclo hidrológico e dos micro-climas locais, previsão das próximas precipitações e finalmente o correto destino das águas precipitadas, tentando adotar práticas que mitiguem os impactos da urbanização, assim como a garantia da disponibilidade das águas de chuva, ou seja, trata tanto da drenagem de forma sustentável, quanto do uso racional da água.

Assim, na gestão de recursos hídricos configura-se a discussão da oferta dos recursos relacionados ao ciclo hidrológico, tanto quanto sua utilização propriamente dita, quanto à minimização dos impactos gerados pela ação antrópica, relacionada a eventos hidrológicos críticos (enchentes e seca). 


\section{Procedimentos Metodológicos}

\subsection{Bases Teórico-Metodológicas}

Ao assumir a atitude de quem considera o papel da ciência geográfica, no rol das outras ciências, como a busca da análise unitária de seus diversos elementos componentes onde, as relações sociedade-natureza consistem em seu objetivo primordial e também em seu grande trunfo metodológico, parte-se da hipótese de que mais importante que a problemática específica de cada uma das esferas que compõem o conhecimento geográfico, é a resultante que converge destas interações.

No momento em que o homem avança na dominação e ocupação do território, primordialmente como um substrato, construindo cidades, expandindo o comércio, instalando indústrias e extraindo recursos naturais, ou seja, ao transformar a superfície terrestre, este se constitui em um dos grandes agentes modificadores do ambiente.

Sant'Anna Neto (1995, p.30) afirmou que como "este ambiente é 'vivo' e regulado por processos e dinâmicas próprias, responde às alterações impostas pelo homem, resultando em níveis de derivações dos sistemas, naturais e antrópicos, dos mais variados".

A explosão urbana é um fenômeno mundial, mas é nos países subdesenvolvidos que os problemas de infraestrutura se agravam. Embora seja ainda um processo em curso, verifica-se que as maiores aglomerações urbanas do mundo crescem em ritmo acelerado nos países subdesenvolvidos.

As cidades são sistemas complexos, caracterizando-se como organismos extremamente dinâmicos, suscetíveis a entrada de fluxos de energia 
e massa. A importância crescente das áreas urbanas em termos demográficos, econômicos e culturais faz com que os problemas ambientais gerados por estes núcleos, sejam cada vez mais uma prioridade para pesquisadores de diversas áreas, pois os mesmos podem afetar diretamente a qualidade de vida das pessoas que aí residem.

Devido à constante degradação dos ambientes urbanos e seus respectivos efeitos sobre a qualidade de vida dos cidadãos que aí residem, tem aumentado por parte dos pesquisadores e planejadores a preocupação com a gestão urbana. Neste contexto a análise climática ganha destaque, pois possibilita o estudo de várias problemáticas socioambientais, tais como as mudanças nos regimes de precipitação, que podem causar graves problemas para as populações urbanas.

O aumento do processo de urbanização que ocorreu no Brasil por volta da década de 1960 fez com que surgisse uma maior preocupação com a qualidade ambiental e impulsionou os primeiros estudos sobre o Clima Urbano.

Em 1976 foi publicada a tese de livre docência do Professor Carlos Augusto de Figueiredo Monteiro, que apresentava pela primeira vez a metodologia do Sistema Clima Urbano (S.C.U.) e que foi aplicada em seguida para as cidades de Porto Alegre, Salvador, Rio de Janeiro e São Paulo.

Para Monteiro (1976) a cidade é cada vez mais a morada do homem e é também o lugar da mais efetiva interação entre este e a natureza. O homem promove uma série de mudanças concentradas no meio natural, que se aglutinam em forma das edificações urbanas e que fazem "[...] com que as cidades sejam os lugares onde as resultantes ambientais configuram-se como obra conjunta de uma natureza retrabalhada e aperfeiçoada aos propósitos do viver humano" (Monteiro, 2003. p.10). 
Monteiro (1976) construiu o Sistema Clima Urbano baseado na Teoria Geral dos Sistemas (TGS), criada por Ludwig Von Bertalanffy, associada ao principio do holismo - holon - de Arthur Koestler. A escolha paradigmática do autor deveu-se a que esta base seria capaz de revelar a essência do clima urbano, por ser este um fenômeno de complexidade elevada. Desta forma, Monteiro estabeleceu o S.C.U. como um sistema complexo, aberto e adaptativo, que ao receber energia do ambiente maior no qual se insere (energia solar) a modifica substancialmente.

A metodologia do S.C.U. projeta-se sobre a cidade e seus problemas, tendo como premissa os três elementos que fundamentam a climatologia em geral: temperatura, umidade e pressão atmosférica. Esta abordagem também foi inovadora no sentido de analisar a geração do clima urbano através da idéia de co-participação entre o homem e a natureza e não do antagonismo entre os mesmos.

A estrutura interna do S.C.U. não pode ser definida pela simples superposição ou adição de suas partes (compartimentação ecológica, morfológica, ou funcional urbana), mas somente por meio da íntima conexão entre elas. (MONTEIRO, 1976, p.99).

Monteiro considera o clima urbano como o clima que abrange um determinado espaço terrestre e sua urbanização, sendo que o espaço urbanizado constitui o núcleo do sistema. O S.C.U. é passível de auto-regulação e é centrado na atmosfera (operador) e no homem (operando).

Considerando o Sistema Clima Urbano como um sistema aberto é necessário considerar, além dos fatores geradores de energia externos, os fatores internos, isto é, o homem e a dinâmica criada por ele no espaço urbano.

Assim, dentro do espaço urbano, o homem:

[...] na medida em que conhece e é capaz de detectar suas disfunções, pode, através do seu poder de decisão, intervir e 
adaptar o funcionamento do mesmo, recorrendo a dispositivos de reciclagem e/ou circuitos de retroalimentação capazes de conduzir - seu desenvolvimento e crescimento seguindo metas preestabelecidas. (MONTEIRO, 2003, p.25)

O S.C.U. possui também uma resultante que pressupõe elementos que caracterizam a participação urbana no desenvolvimento do sistema. Observada a devida complexidade de se analisar estes elementos, se fez necessária uma simplificação classificatória que foi expressa através da ideia dos canais de percepção humana. As ilhas de calor, a poluição atmosférica e as precipitações possuem destaque dentro dos climas urbanos, refletindo suas peculiaridades. A análise é dividida entre os canais de percepção do Conforto Térmico, Qualidade do Ar e Meteoros de Impacto, cada um deles ligado a um subsistema do S.C.U., que são respectivamente o Termodinâmico, o Físico-Químico, e o Hidrometeórico.

O Conforto Térmico, ligado ao subsistema Termodinâmico do S.C.U., engloba as componentes derivadas do calor, ventilação e umidade, enquanto a Qualidade do Ar, ligada ao subsistema Físico-Químico, se expressa pela poluição atmosférica, que tem uma associação muito direta com os distintos tipos de tempo geradores da concentração ou da dispersão da poluição pelo ar.

Os Meteoros de Impacto, canal analisado nesta pesquisa, agrupam as formas meteóricas, hídricas (como chuvas, neves e nevoeiros), mecânicas (como os tornados) e elétricas (tempestades), que têm a possibilidade de, eventualmente, se manifestar com grande intensidade e resultam em grandes impactos urbanos, causando perturbações e desorganizando a circulação e os serviços urbanos. Nas cidades brasileiras, são constantes os problemas derivados do subsistema hidrometeórico devido a sua configuração climática e aos problemas de ordem socioambientais existentes. 


\subsection{Metodologia}

A visualização das relações entre os elementos da paisagem leva o pesquisador a compreender a dinâmica da área estudada e como ela dialoga com sua circunvizinhança.

Assim sendo, a metodologia do S.C.U. serve não só para a delimitação das alterações climáticas em áreas urbanas, mas principalmente para a detecção dos problemas existentes no local e o grau de responsabilidade da ação antrópica sobre os mesmos, assim como o planejamento de estratégias para conter, reverter ou amenizar os impactos já causados. Essa metodologia vai ao encontro da busca atual pelo manejo sustentável dos recursos naturais.

Para tentar compreender de maneira mais clara esta dinâmica foi necessária nesta pesquisa a realização de um amplo levantamento dos processos que deram origem à Região Metropolitana de São Paulo como conhecemos hoje, com seus principais eixos de crescimento, densidade populacional, cobertura vegetal arbórea, tipos de ocupação urbana nos diferentes setores das cidades, além da interpretação e sistematização dos dados de precipitação coletados junto aos postos pluviométricos da RMSP e as estações meteorológicas monitoradas pelo INMET, os estudos literários e o levantamento dos dados referentes à demanda e disponibilidade dos recursos hídricos disponibilizados por diversos órgãos governamentais, em especial os dados referentes ao volume de armazenamento dos mananciais que atendem a RMSP desde o ano de 2003, fornecidos pela SABESP ${ }^{1}$.

\footnotetext{
${ }^{1}$ Foram realizados diversos contatos com a SABESP para obtenção de uma série mais extensa de dados, mas a empresa se recusou a fornece-los (Anexo).

A série utilizada foi obtida através site: http://site.sabesp.com.br/site/Default.aspx
} 
A avaliação das tendências e variabilidade do fenômeno pluvial foi realizada através da utilização dos dados de precipitação pluviométrica de sete (07) postos pluviométricos distribuídos pela RMSP e de três (03) estações meteorológicas convencionais monitoradas pelo INMET, tanto em termos sazonais quanto anuais, a partir de valores diários e mensais. Procurou-se obter séries longas, com pelo menos 30 anos de dados e que possuíssem registros até o ano de 2013, para que fosse possível a comparação dos dados em diferentes períodos históricos.

Outra precaução tomada foi em relação a confiabilidade dos dados, sendo descartados além dos postos com séries inferiores a 30 anos, também aqueles que apresentavam muitas falhas e os que tivessem valores muito discrepantes em relação aos postos mais próximos.

A principal técnica estatística utilizada nesta pesquisa foi a Análise de Séries Temporais, que tem o objetivo de detectar a existência e magnitude de tendências significativas das séries selecionadas.

As informações referentes ao abastecimento de água urbano provêm de órgãos como a Agência Nacional de Águas (ANA), Departamento de Águas e Energia Elétrica (DAEE) e a Companhia de Saneamento Básico do Estado de São Paulo (SABESP). Estas empresas disponibilizam seus dados na internet e são de fácil acesso para toda população. Para análise dos valores numéricos, tanto da série histórica quanto do abastecimento urbano, foram elaborados gráficos em softwares estatísticos apropriados, facilitando, assim, a melhor visualização dos dados.

O levantamento bibliográfico foi de fundamental importância para todas as etapas desta pesquisa, e se realizou a fim de auxiliar na compreensão dos elementos formadores e transformadores do "fenômeno" urbano. 


\section{O fenômeno da urbanização e seus impactos}

\subsection{O Processo de Urbanização no Brasil}

O processo de urbanização no Brasil vincula-se às transformações sociais que vêm mobilizando a população das áreas rurais e incorporando-a à economia urbana, bem como aos padrões de sociabilidade e cultura da cidade. A inserção no mercado de trabalho capitalista e a busca por estratégias de sobrevivência e mobilidade social implicam na instalação em centros urbanos e em uma mobilidade espacial constantemente reiterada, que se desenrola no espaço da cidade ou tem nela sua base principal.

A maioria dos brasileiros vive hoje nas cidades. Isso significa que pouco resta da sociedade rural que caracterizava o país nos anos 1940, quando cerca de $70 \%$ da população morava no campo.

Desde a revolução urbana brasileira, consecutiva à revolução demográfica dos anos de 1950, presenciamos primeiro uma urbanização aglomerada e posteriormente a urbanização concentrada, com o aumento de cidades de porte médio e com um crescimento considerável das cidades com mais de um milhão de habitantes.

Foi a partir dos anos 1950 que se notou mais claramente uma tendência à aglomeração populacional e do consequente processo de urbanização. Os núcleos com mais de 20 mil habitantes presenciaram o crescimento de sua participação no conjunto da população brasileira, passando de pouco menos de $15 \%$ do total na década de 1940 , para constituir mais da metade da população em 1980. 
Mas as realidades regionais são distintas, e o peso relativo dessas aglomerações na população total e na urbana de cada região foi um reflexo da história de cada uma delas. O que era conhecido como "cidade média" entre as décadas de 1940 e 1950 naturalmente não corresponde a "cidade média" de 1980. Levando em consideração os 501 centros urbanos que tinham mais de 20 mil habitantes em 1980, Bremaeker (1986, p.280) assim descreve o crescimento de sua importância relativa:

Em 1950, estes 501 centros urbanos detinham 13,6 milhões de habitantes, que constituíam $72,6 \%$ da população urbana brasileira e $26,3 \%$ da população total. Em 1969, continham 23,5 milhões de habitantes, que representavam $73,5 \%$ da população urbana e $33,1 \%$ da população total. Em 1970, já retinham 40,3\% de habitantes que constituíam $76,2 \%$ da população urbana e $42,6 \%$ da população total. Finalmente, em 1980, estes 501 centros urbanos alcançavam a marca de 62,5 milhões de habitantes, que correspondiam a $76,3 \%$ da população urbana e a $51,6 \%$ da população brasileira.(BREMAEKER, 1986, p.280)

A população urbana das aglomerações com mais de 20 mil habitantes cresceu mais rapidamente que a população total e que a população urbana do país, e este fenômeno se verificou também em escala regional. Se considerarmos as cinco regiões brasileiras, o incremento maior entre os anos de 1960 e 1980 verificou-se no Norte e no Centro-Oeste, respectivamente ${ }^{2}$.

No entanto, a comparação do volume demográfico correspondente às diversas grandes regiões, durante este mesmo período, revelou a grande concentração dos respectivos efetivos no Sudeste, seguido de muito longe pelo Nordeste e Sul.

O número das aglomerações onde a população ultrapassava os 100 mil habitantes também não parou de crescer, e as cidades com mais de um milhão de habitantes, que eram apenas duas em 1960 (São Paulo e Rio de Janeiro)

\footnotetext{
${ }^{2}$ Site do IBGE: http://www.ibge.gov.br/home/ Acesso em 15/12/2012.
} 
passaram a quinze em 2010. Esses números ganham maior significação se lembrarmos que, em 1872, a soma da população das dez maiores cidades brasileiras não chegava a um milhão de habitantes.

É possível constatar, através destes dados, o fenômeno da metropolização, termo utilizado ainda de forma incipiente no Brasil, nesse sentido, é legitima a preocupação de Celso Lamparelli (1990, p.56), quando afirma que continuamos "[...] insistindo em referências que já não iluminam suficientemente a problemática das transformações vividas ultimamente pelo espaço."

O fenômeno da metropolização vai além da denominação legal. O país possui hoje vinte regiões metropolitanas, criadas por lei para atender a critérios certamente válidos de um ponto de vista oficial. Segundo Langenbuch (1971, p.1), que já falava sobre esses importantes centros a mais de trinta anos, "[...] a metrópole constitui um tipo especial de cidade, que se distingue das menores não apenas por sua dimensão, mas por uma série de fatos, quer de natureza quantitativa, quer de natureza qualitativa".

As atuais regiões metropolitanas têm em comum dois elementos essenciais: são formadas por mais de um município, com um município núcleo representando uma área bem maior que as demais e se constituem como objetos de programas especiais, levados adiante por organismos regionais especialmente criados, com a utilização de normas e recursos em boa parte federais. As metrópoles são, na realidade, regiões de planejamento, onde o que é feito, todavia, não atende a problemática geral da área, limitando-se a aspectos setoriais. A atuação do poder público nessas áreas, voltada para uma socialização capitalista, é acompanhada pela expansão periférica, que inclui a 
criação de direitos industriais, e pela concentração dos serviços de interesse coletivo.

É interessante ressaltar que dentro deste quadro, a Região Metropolitana de São Paulo possui maior destaque, pois é desde o decênio 19401950 que o incremento demográfico em números absolutos dessa área do país vem sendo maior que o correspondente às outras regiões, diminuindo somente a partir da década de 1990 (Tabela 01).

Tabela 01: Taxas anuais de crescimento populacional (\%): RMSP, Estado de São Paulo, Brasil $1940-2010$.

\begin{tabular}{|c|c|c|c|}
\hline Anos & RMSP & Estado de São Paulo & Brasil \\
\hline $1940-1950$ & 5,54 & 2,44 & 2,34 \\
\hline $1950-1960$ & 5,95 & 3,57 & 3,17 \\
\hline $1960-1970$ & 5,44 & 3,32 & 2,89 \\
\hline $1970-1980$ & 4,46 & 3,52 & 2,51 \\
\hline $1980-1991$ & 2,00 & 2,00 & 1,77 \\
\hline $1991-2000$ & 1,64 & 1,8 & 1,61 \\
\hline $2000-2010$ & 0,97 & 1,08 & 1,18 \\
\hline
\end{tabular}

Fonte: IBGE - Censos Demográficos

Org. Lima, 2013

O fato metropolitano se apresenta como uma totalidade menor, dentro de um cenário mais abrangente, constituída pela formação social nacional, na qual só as aglomerações urbanas com determinado nível de complexidade podem ser consideradas como totalidades, o que não cabe aos outros tipos de formações regionais. As metrópoles podem, assim, ser analisadas segundo um critério sistêmico, desde que a percepção das variáveis constitutivas seja considerada. Um estudo mais profundo pode, desse modo, ser realizado, o que, aliás, é desejável, caso se pretenda realmente conhecer o fenômeno e chegar a 
propor soluções. O enfoque de planejamento não deve ser autônomo, mas subordinado ao conhecimento intrínseco da realidade global.

\subsection{Caracterização da Área de Estudo}

\subsubsection{O Processo de Urbanização na Região Metropolitana de São Paulo}

No Brasil, a urbanização passou por um processo de aceleração a partir dos anos de 1950 e logo se caracterizou pela metropolização e pela rápida incorporação das áreas rurais. De acordo com Santos (1994) as perspectivas gerais são ainda de contínuo crescimento do fenômeno nos próximos anos.

A evolução urbana da Grande São Paulo, presenciada nas últimas décadas, configura a emergência de uma estrutura metropolitana, que se caracteriza pela sua agregação num conjunto urbano contínuo formado por vários municípios, uma escala populacional da ordem de vários milhões de pessoas que vivem ou exercem atividades nessa área e o desenvolvimento de um intrincado sistema de polos de concentração de atividades terciárias.

A primeira fase evolutiva estendeu-se entre as décadas de 1930 e 1940, e poderia ser denominada de pré-metropolitana. Nessa fase configuraramse alguns elementos fundamentais da estrutura metropolitana, tais como às áreas de concentração industrial distribuídas ao longo da Estrada de Ferro Santos - Jundiaí e da Estrada de Ferro Sorocabana, o que vai facilitar o início da integração dos municípios de Osasco, São Caetano do Sul e Santo André num contínuo urbano.

Paralelo à integração dos municípios acima citados, incrementa-se nessa fase a ocupação, com viés predominantemente residencial, nos municípios 
pertencentes ao quadrante leste da área, que também passam a ter suas áreas urbanas conurbadas com a aglomeração principal no eixo da Estrada de Ferro Central do Brasil.

A fase posterior do processo evolutivo estende-se até o início dos anos de 1960. Neste período foi possível perceber a emergência de novos elementos de infraestrutura, em especial as rodovias estaduais e federais, possibilitando a incorporação à área urbana do município de São Paulo de novos espaços, pertencentes a municípios até então isolados.

É nesta fase que ocorre a grande aceleração do processo de industrialização, por conta, principalmente, das rodovias recém abertas, que deram origem a novas áreas de concentração linear de estabelecimentos industriais que posteriormente se incorporaram como elementos da estrutura urbana metropolitana.

A terceira fase evolutiva, que vai de 1960 à 1970, é marcada pela estruturação de blocos de atividades industriais, liderados pelo desenvolvimento da indústria de automóveis, que reforçou as concentrações industriais ao longo da Via Anchieta e nos municípios à sudeste da área central.

Um segundo impacto causado à atividade industrial foi a motorização da população, que gerou um aumento da demanda por novas vias e espaços para circulação. Essa nova realidade se apresentou como um considerável agravante dos problemas de aglomeração, gerando situações graves de crise das estruturas urbanas.

A metrópole ainda não estava preparada para o forte crescimento da frota de automóveis, e a motorização repercutiu diretamente na própria estrutura metropolitana, e contribuiu para mudança de certos hábitos de 
consumo e culturais, dando origem a novas concentrações comerciais e de atividades terciárias em geral.

Foi esse processo evolutivo que elevou a extensão de áreas ocupadas pelos usos urbanos, na medida em que o crescimento das atividades secundárias demandava a alocação de espaços maiores para a indústria e a Região Metropolitana de São Paulo continuava a ostentar um quadro de ofertas de empregos, nitidamente superior a das demais regiões do país. Esse crescimento físico se traduziu novamente na incorporação de novos municípios ao núcleo central e deu origem a organização espacial dos setores econômicos como conhecemos hoje (Figura 04).

A Região Metropolitana de São Paulo, composta por 39 municípios (Figura 05), foi oficialmente instituída pela Lei Complementar Federal no 14, de 1973, e disciplinada pela Lei Complementar Estadual no 94, de 1974. No entanto, sua existência legal e política dependeu da aprovação de uma lei estadual específica, de acordo com as regras da Constituição Federal de 1988, que atribuiu aos estados a responsabilidade pela criação das regiões metropolitanas.

Nos anos 1980 a mancha urbana continuou crescendo, caracterizada pela lógica dos loteadores clandestinos, o que levou a ocupação de áreas cada vez mais distantes dos bairros intermediários, inclusive próximas a mananciais protegidas por lei. 


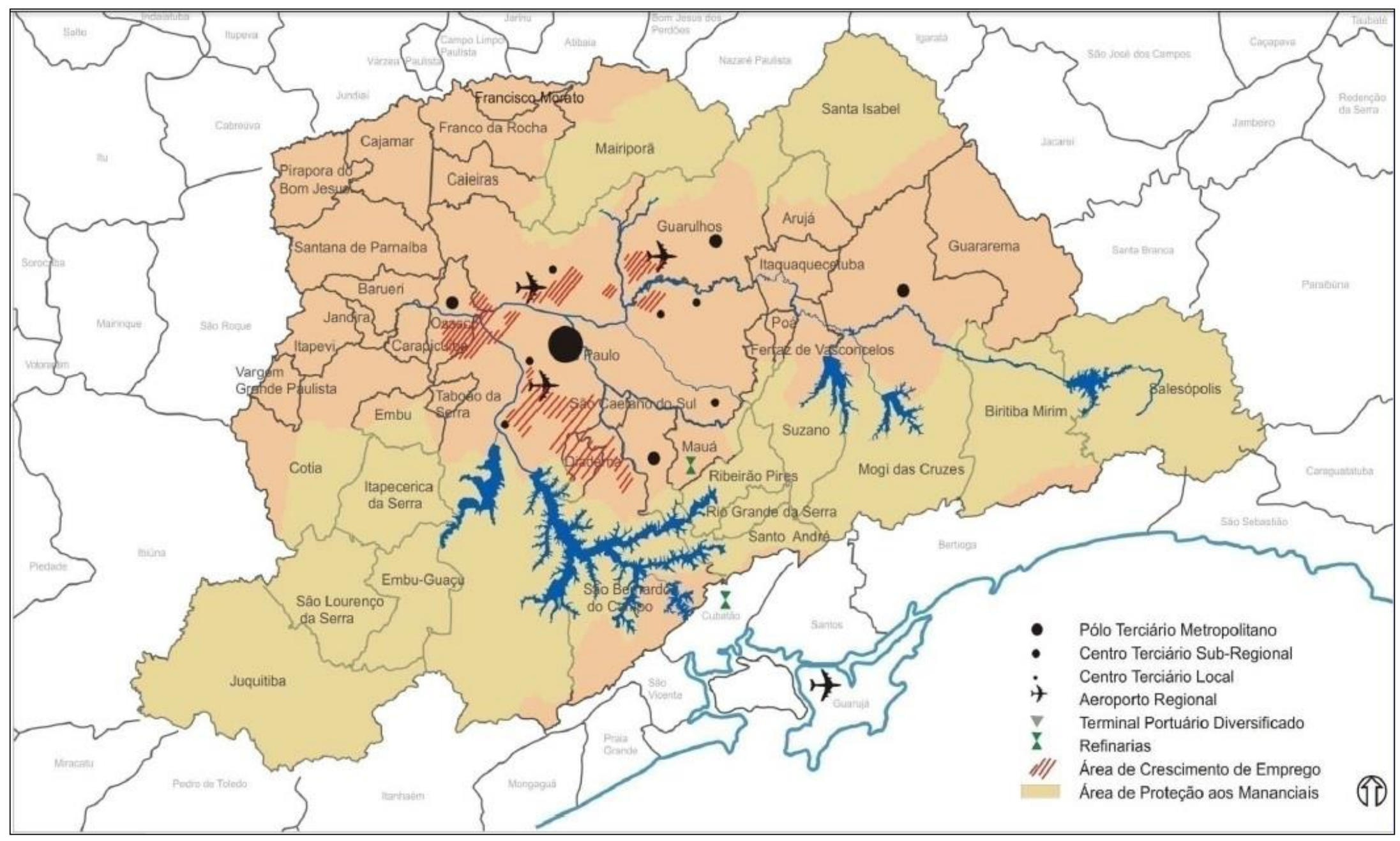

Figura 04: Região Metropolitana de São Paulo - Complementaridades Funcionais Fonte: Empresa Paulista de Planejamento Metropolitano - EMPLASA 2011 


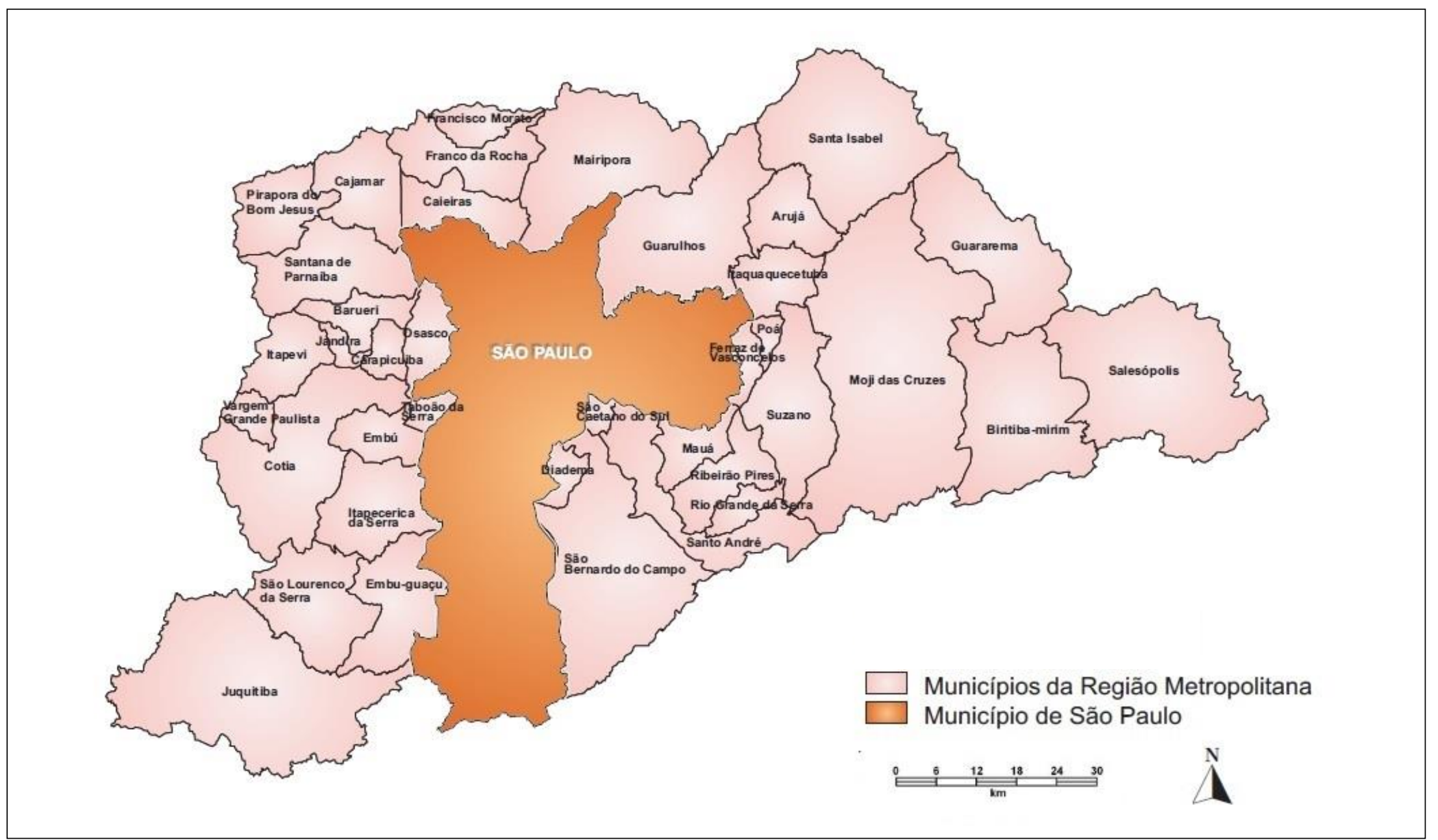

Figura 05: Municípios da Região Metropolitana de São Paulo

Fonte: Instituto Brasileiro de Geografia e Estatística - IBGE; Secretaria Municipal de Desenvolvimento Urbano/SMDU; Departamento de Produção e Análise de Informação/DEINFO. 
Já a partir da década de 1990, a reestruturação urbano-industrial fez com que as desigualdades se acirrassem. O Poder Público, que deveria implantar serviços para atender de maneira satisfatória a população e os empregadores desse centro que crescia tão rapidamente, tornou-se refém das grandes corporações e aparelhou a metrópole somente para atendê-las, dando origem a uma "[...] metrópole corporativa e fragmentada" (Santos 1990, p.94).

São Paulo concentra as polaridades das cidades mundiais, apresentando processos contraditórios que abrangem desde as conhecidas tendências à desconcentração metropolitana, à diminuição do número de indústrias e terceirização (em especial com expansão do setor serviços, telecomunicações e informática) até as crescentes exclusão e miséria sociais, o aumento do desemprego, a informatização e terceirização e a configuração espacial desses processos: periferias desequipadas, crise de moradia popular (favelas, cortiços, casas precárias, homless), condomínios fechados para estratos de renda alta e média e seu contraponto comercial: os shopping centers. Na desigualdade do espaço estão zonas de deterioração em contraste com áreas de 'renovação' urbana e a distribuição diferenciada de ocorrências de chacinas, risco à violência, discriminação, além de cenários de devastação ecológica. (VÉRAS, 1999, p.197)

Ao contrário do que ocorre com a maior parte das regiões administrativas do Estado, na Região Metropolitana de São Paulo predomina claramente o desenvolvimento do tipo urbano (Figura 06). Essa predominância não se caracteriza somente pela elevada taxa de população urbana e pela extensão da área urbanizada, mas também pela incorporação, a um mesmo contexto urbano contínuo, de áreas pertencentes à cerca de dezoito municípios, ao mesmo tempo em que os demais municípios da região se unem por estreitas relações funcionais a esse aglomerado, fazendo com que toda região se polarize de maneira muito forte em torno da área urbana e das atividades desenvolvidas, que alcançam expressão nacional de grande amplitude. 


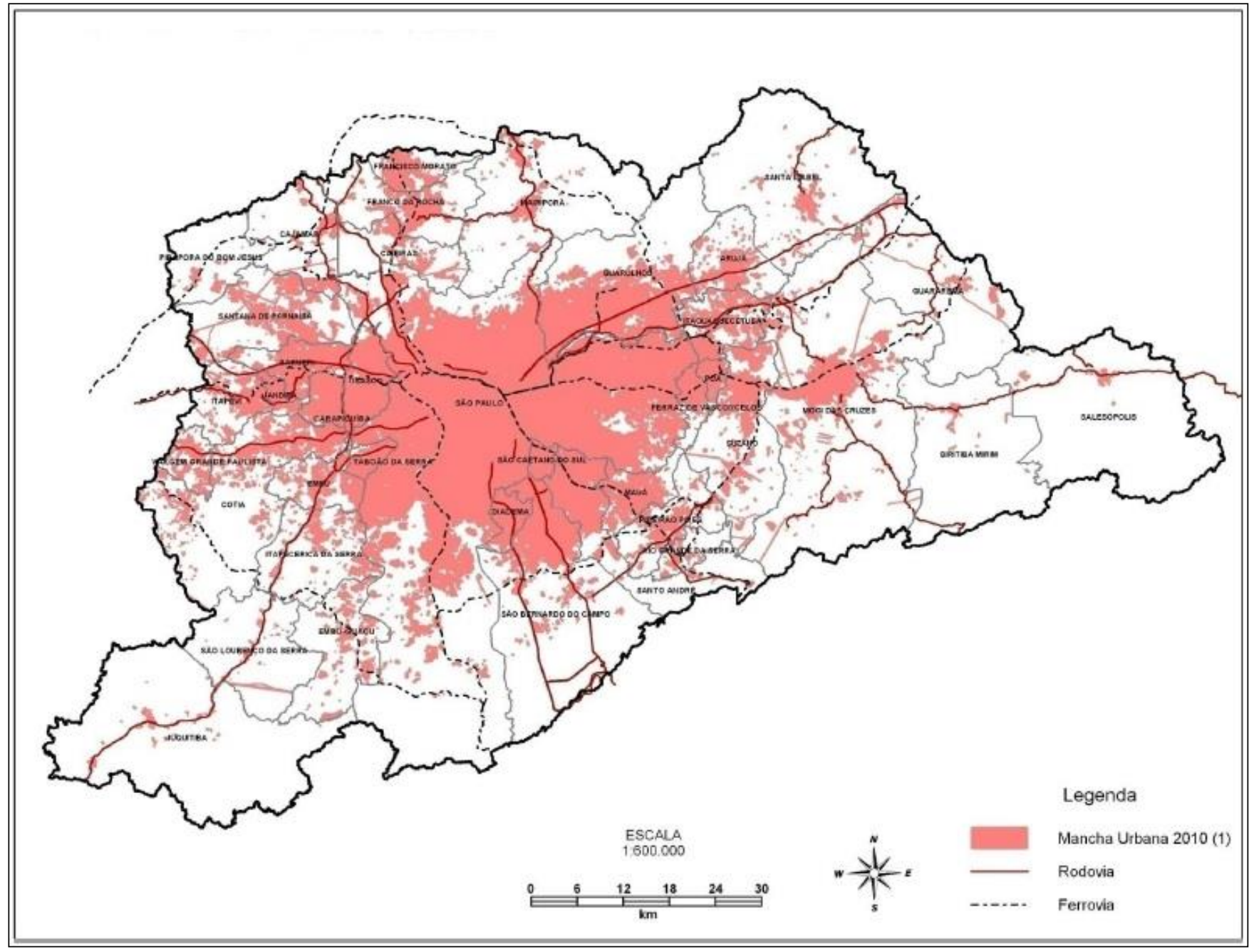

Figura 06: Região Metropolitana de São Paulo - Mancha Urbana Contínua Fonte: Empresa Paulista de Planejamento Metropolitano - EMPLASA 


\subsubsection{O Sítio Urbano e o Contexto Climático da Região Metropolitana de São Paulo}

Denomina-se sítio urbano a base físico-natural sobre a qual uma cidade é construída, sua caracterização deve levar em consideração elementos como clima, vegetação, hidrografia, geomorfologia e solo, tendo por objetivo auxiliar na compreensão do modo como a urbanização se processou e como pode vir a produzir problemas ambientais, tais como a escassez de água, poluição atmosférica, inundações, entre outros.

A Região Metropolitana de São Paulo localiza-se a uma altitude média de 750 metros acima do nível do mar, possuindo grande parte do seu território na Bacia do Alto Tietê, dentro do Planalto Paulistano. Fazem parte do seu território, também, as bacias do Rio Jundiaí, ao norte, do Rio Sorocaba, no Planalto de Ibiúna a oeste, dos Rios Itatinga, Capivari e Itapanhaú, todos pertencentes a vertente oceânica da Serra do Mar ao sul, Rio Paraíba a leste e Rio Ribeira do Iguape a sudoeste.

De acordo com Cabral (2002) a parte central da Região Metropolitana, área mais urbanizada da metrópole, é formada por colinas suavemente onduladas, pertencentes à bacia sedimentar pliocênica de São Paulo, por onde passam as águas do Rio Tietê e alguns de seus afluentes, e por planícies aluviais holocênicas. Outras áreas menores de planícies e colinas também aparecem nos setores mais a leste, respectivamente das bacias dos rios Paraíba e Sorocaba.

Os outros setores da metrópole apresentam relevo mais acidentado, com declividades variando de $20 \%$ a $40 \%$ ou mais em alguns pontos, e amplitudes topográficas de até 400 metros. 
A leste da região central se encontra a Serra do Itapeti, que forma o divisor de águas das bacias do Alto Tietê e Paraíba. Também a leste, mas já em direção ao sul e sudeste, encontra-se a morraria do Embu, na zona de contato com o rebordo da Serra do Mar. Finalmente à norte e noroeste localizam-se as Serras da Cantareira, Pedra Branca, Bananal e Itaqui, que fazem parte da formação da Serrania de São Roque.

Em relação à altimetria da atual área atingida pelo processo de urbanização, encontramos topos de até 800 metros aproximadamente, com altitudes que variam de 720 a 724 metros e correspondem ao nível dos talvegues e planícies de inundação.

Climatologicamente a Região Metropolitana de São Paulo localiza-se em uma área com características de transição entre os Climas Tropicais Úmidos de Altitude, com período seco definido, e aqueles subtropicais, permanentemente úmidos, do Brasil meridional. Essa característica de transição pode ser explicada pelo fato da metrópole estar localizada junto ao Trópico de Capricórnio numa latitude aproximada de $23^{\circ} 21^{\prime}$ 'S e longitude de $46^{\circ} 44^{\prime} \mathrm{W}$.

De acordo com Azevedo (2001) uma das características climáticas dessa área de transição zonal é a alternância das estações (quente e úmida e outra fria e relativamente mais seca) ao lado das variações bruscas do ritmo e da sucessão dos tipos de tempo. É possível constatar situações meteorológicas (estados atmosféricos) de intenso aquecimento bem como de intenso resfriamento em curtos períodos te tempo.

De acordo com a classificação climática internacional (classificação de Köeppen) a região se enquadra na Classe C (clima oceânico), com tipo Cwa, que é caracterizado pelo clima tropical de altitude, com chuvas no verão e seca no inverno. Segundo dados do Centro de Pesquisas Meteorológicas e Climáticas 
Aplicadas a Agricultura (CEPHAGRI), as temperaturas da metrópole variam entre $12^{\circ} \mathrm{C}$ no mês mais frio e $28^{\circ} \mathrm{C}$ no mês mais quente e a temperatura média anual é de $20,7^{\circ} \mathrm{C}$. A precipitação total anual é de aproximadamente $1300 \mathrm{~mm}$, e se concentra principalmente no verão. A umidade relativa do ar é alta, com médias acima de $70 \%$ durante o verão.

Cavalcanti et al (1982) afirma que, dada a sua posição geográfica, a Região Metropolitana de São Paulo é afetada pela maioria dos sistemas de grande escala provenientes do Polo Sul, que atingem o sul/sudeste do país. Vórtices Ciclônicos de altos níveis, originários do Oceano Pacífico polar organizam-se com intensa convecção associada à instabilidade causada pelo jato subtropical. Também, as linhas de instabilidade pré-frontais, geradas a partir da associação de fatores dinâmicos de grande escala e características de meso escala, são responsáveis pelo aumento da instabilidade atmosférica e precipitações intensas.

Além dos fenômenos de grande escala, o fato de ser uma região de transição entre padrões climáticos e topográficos, faz com que esta área sofra o efeito da influência de fenômenos meteorológicos de meso e micro escalas realçados. Como exemplo pode-se citar a presença de interfaces entre a terra e grandes espelhos d'água que podem gerar regimes locais de circulação, dando origem a elementos como as brisas.

Outro fenômeno que pode ser detectado esporadicamente sobre a região é a Zona de Convergência do Atlântico Sul (ZCAS), que se caracteriza pela atuação de sistemas tropicais em conjunto com sistemas típicos de latitudes médias. Durante os meses de maior atividade, o fenômeno faz com que uma banda de nebulosidade permaneça semi-estacionária por vários dias, o que favorece a ocorrência de precipitação intensa. 
De acordo com Tarifa e Armani (2000), durante o período seco a região sofre a influência dos anticiclones (sistemas de alta pressão) subtropical e polar. A rápida atuação dos sistemas frontais provenientes do extremo sul do continente causa pouca precipitação durante o período. A diminuição da velocidade dos ventos e consequente calmaria se dão quando a região está sob a atuação do anticiclone subtropical marítimo e uma frente fria se encontra ao sul do estado.

A diminuição da velocidade do vento associada à grande estabilidade atmosférica e a formação de inversão térmica muito próxima a superfície tornam as condições de dispersão de poluentes desfavoráveis. Esse quadro só é alterado com a chegada de uma nova massa de ar associada a um sistema frontal.

Em relação às chuvas, a combinação de ventos oceânicos úmidos com o posicionamento frontal da escarpa Planaltina e das serras Cristalinas do Além Tietê favorece a variabilidade espacial da precipitação na RMSP. O vale do Tietê é a área que apresenta menores índices de precipitação, bem como as maiores perdas por evapotranspiração, se convertendo no trecho mais quente e menos úmido em relação à bacia do Alto Tietê.

$\mathrm{Na}$ região metropolitana os sistemas de precipitação de origem convectiva são os mais representativos e são atribuídos à topografia, às características de superfície, à injeção de umidade trazida pela brisa marítima e a existência de Ilhas de Calor.

As precipitações da Região Metropolitana de São Paulo apresentam um padrão típico de regime pluviométrico tropical, do ponto de vista climatológico, não se define um período de forte estiagem se considerarmos os critérios estabelecidos por Gaussen e Bagnouls (1953). 
A rápida expansão urbana que se efetivou na região desde a década de 1960 auxiliou substancialmente para a multiplicação de áreas propícias à inundação. A estrutura urbana que se apresenta hoje não suporta mais o caráter torrencial das chuvas que, aliado a intervenção antrópica, resulta em um cenário de aceleração de processos erosivos, movimentos de massa, entupimento de sumidouros e rompimento de galerias pluviais.

\subsubsection{Uso e Ocupação do Solo na Região Metropolitana de São Paulo}

Como uma ferramenta de gestão adotada para facilitar o entendimento da Região Metropolitana de São Paulo na sua totalidade, a Secretaria de Desenvolvimento Metropolitano ${ }^{3}$ desenvolveu uma divisão dos 39 municípios que compõe a RMSP em sub-regiões (Norte, Leste, Sudeste, Sudoeste e Oeste) sendo o município de São Paulo pertencente a todas.

Através desta divisão é possível avaliar fenômenos como o uso e a ocupação do solo, crescimento da mancha urbana, perda de áreas verdes, entre outros, em escala detalhada a fim de propor políticas de gestão urbana mais pontuais e que atendam os diferentes municípios que compões a RMSP de maneira efetiva.

A divisão em sub-regiões levou em consideração características geográficas e sociais para agrupar os diferentes municípios, de maneira a facilitar a tomada de decisão no que se refere ao desenvolvimento e aplicação de projetos de infraestrutura e ação social.

\footnotetext{
3 A Secretaria de Desenvolvimento Metropolitano é um órgão do Governo do Estado de São Paulo que atualmente se denomina Subsecretaria de Desenvolvimento Metropolitano, devido a reajustes orçamentários realizados durante a primeira gestão do Governador Geraldo Alckmin, passando a fazer parte da Casa Civil do Estado de São Paulo.
} 
Utilizaremos esta divisão para mostrar de maneira mais detalhada as características de ocupação e uso do solo na Região Metropolitana de São Paulo, considerando que uma análise global poderia ocultar nuances importantes de uma área tão extensa e importante.

Mesmo ocupando uma posição privilegiada na economia nacional, a RMSP abriga municípios com diferentes graus de desenvolvimento e níveis de qualidade de vida, o que a torna uma área heterogenia e desigual.

A sub-região norte (Figura 07), constituída pelos municípios de Caieiras, Franco da Rocha, Cajamar, Francisco Morato e Mairiporã caracteriza-se pela presença de municipalidades de pequena extensão territorial e por ser a sub-região de menor porte populacional quando referenciada à Região Metropolitana de São Paulo, totalizando 517.675 habitantes (Censo do IBGE 2010), o que representa $2,6 \%$ do total metropolitano.

O processo de uso e ocupação do solo urbano nesta sub-região foi condicionado por fatores bastante marcantes, como a topografia, a estrutura fundiária e o sistema viário. Possui um relevo bastante acidentado, apresentando formações serranas como o Japi, a Cantareira, a Pedra Vermelha além de morros como o Juqueri, que forçaram a orientação do traçado dos principais eixos viários. 


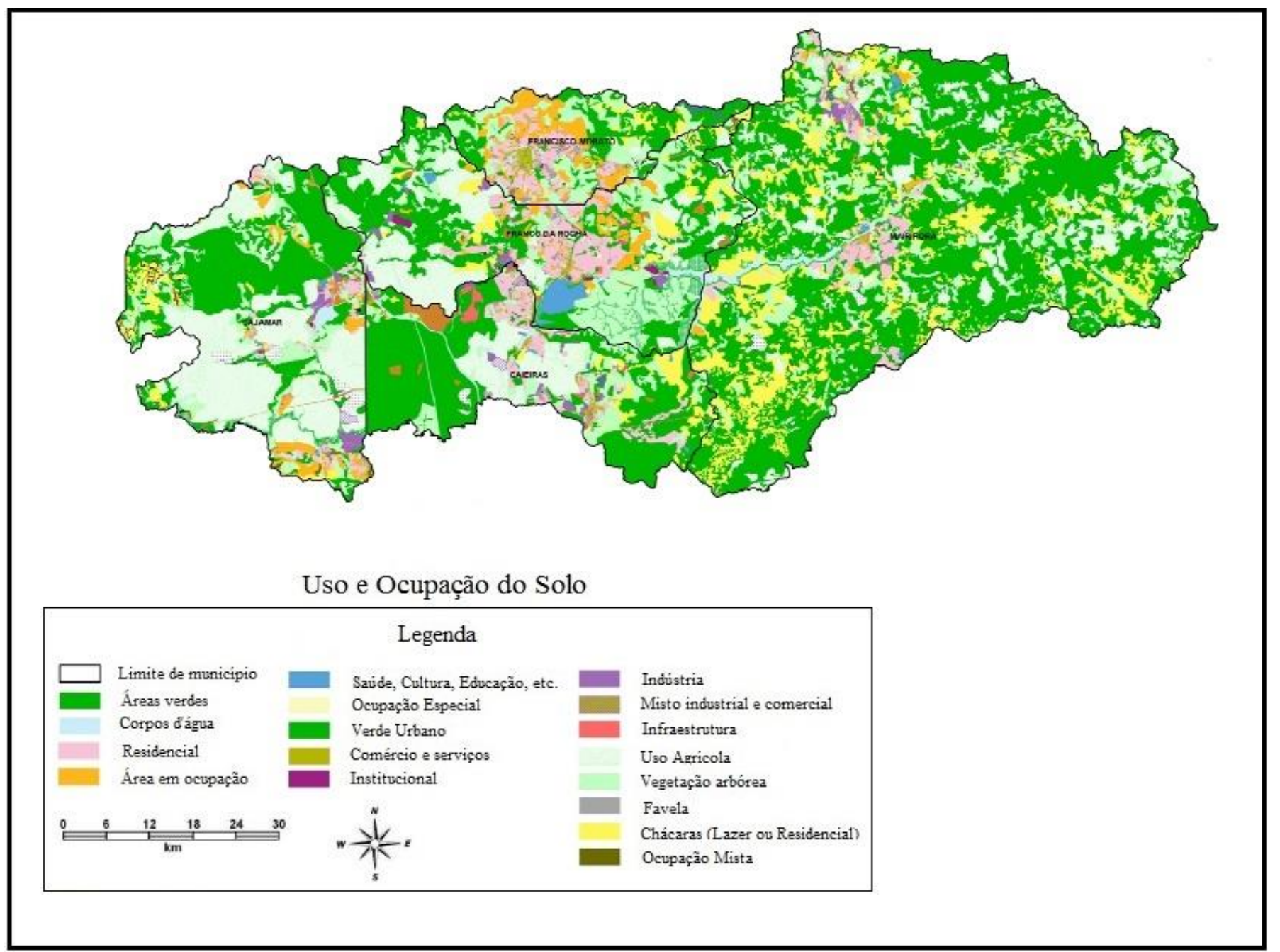

Figura 07: Mapa de Uso e Ocupação do Solo - Sub-região Norte Fonte: Empresa Paulista de Planejamento Metropolitano - EMPLASA

$$
\text { Adap. Lima, } 2014
$$


A sub-região oeste (Figura 08) é formada pelos municípios de Jandira, Carapicuíba, Pirapora do Bom Jesus, Barueri, Santana do Parnaíba e Osasco, possui uma população de aproximadamente 1,7 milhões de pessoas (Censo do IBGE, 2010), o que representa aproximadamente $9 \%$ da população da RMSP e é constituída por municipalidades de pequena extensão territorial.

É interessante perceber que na maioria dos municípios desta subregião a taxa de crescimento populacional dos últimos dez anos foi maior que aquela registrada no restante da RMSP, com destaque para Santana do Parnaíba, no qual foi registrado um valor de quase $4 \%$ segundo dados do IBGE (2010).

O desenvolvimento da sub-região oeste está vinculado à Estrada de Ferro Sorocabana e iniciou-se em princípios do século $X X$, onde pequenos núcleos foram se formando ao longo da ferrovia. Posteriormente as rodovias Castelo Branco e Raposo Tavares passariam a representar um importante papel para o crescimento destes núcleos urbanos. (CUSTÓDIO, 2012)

Esta área apresenta hoje forte industrialização. além de possuir um setor comercial e de serviços bastante desenvolvido. 


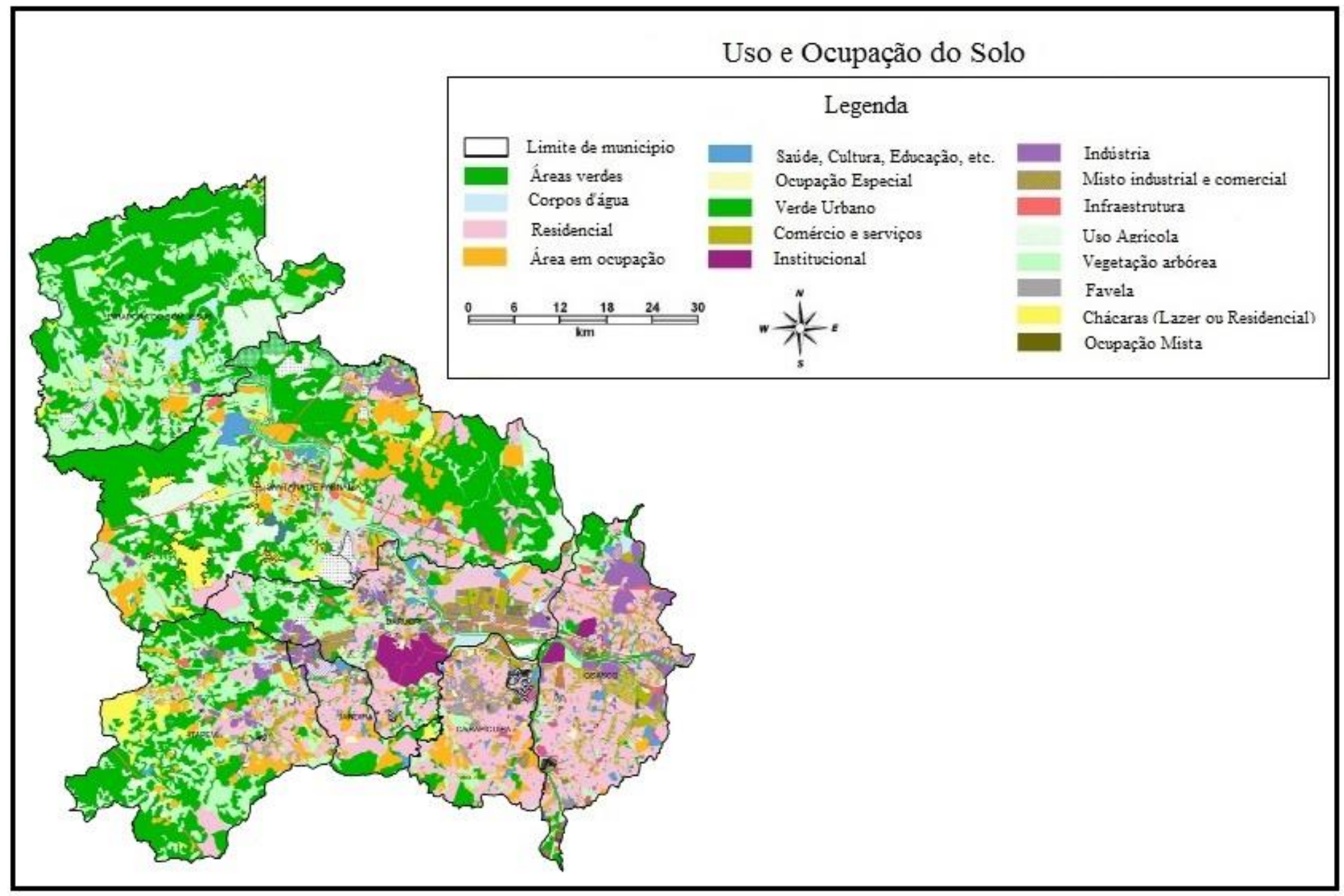

Figura 08: Mapa de Uso e Ocupação do Solo - Sub-região Oeste Fonte: Empresa Paulista de Planejamento Metropolitano - EMPLASA Adap. Lima, 2014 
Possuindo boa parte de seu território em áreas de proteção de mananciais, a sub-região sudoeste (Figura 09) tem seu desenvolvimento condicionado por leis ambientais, que controlam a expansão das manchas urbanas dos municípios.

Como nas demais sub-regiões, os primeiros núcleos urbanos tiveram origem próximos a vias de acesso a outras partes do país, neste caso a Rodovia Régis Bitencurt foi a peça chave para o desenvolvimento desta área. No entanto, atualmente as áreas mais densamente ocupadas estão nos municípios de Embu e Taboão da Serra.

A ocupação inicial desta sub-região se caracterizou pela presença predominante de núcleos residenciais de média e baixa renda. Ao longo da rodovia ocorreu um processo de industrialização, que atualmente está em decadência, dando lugar aos setores de comércio e serviços. 


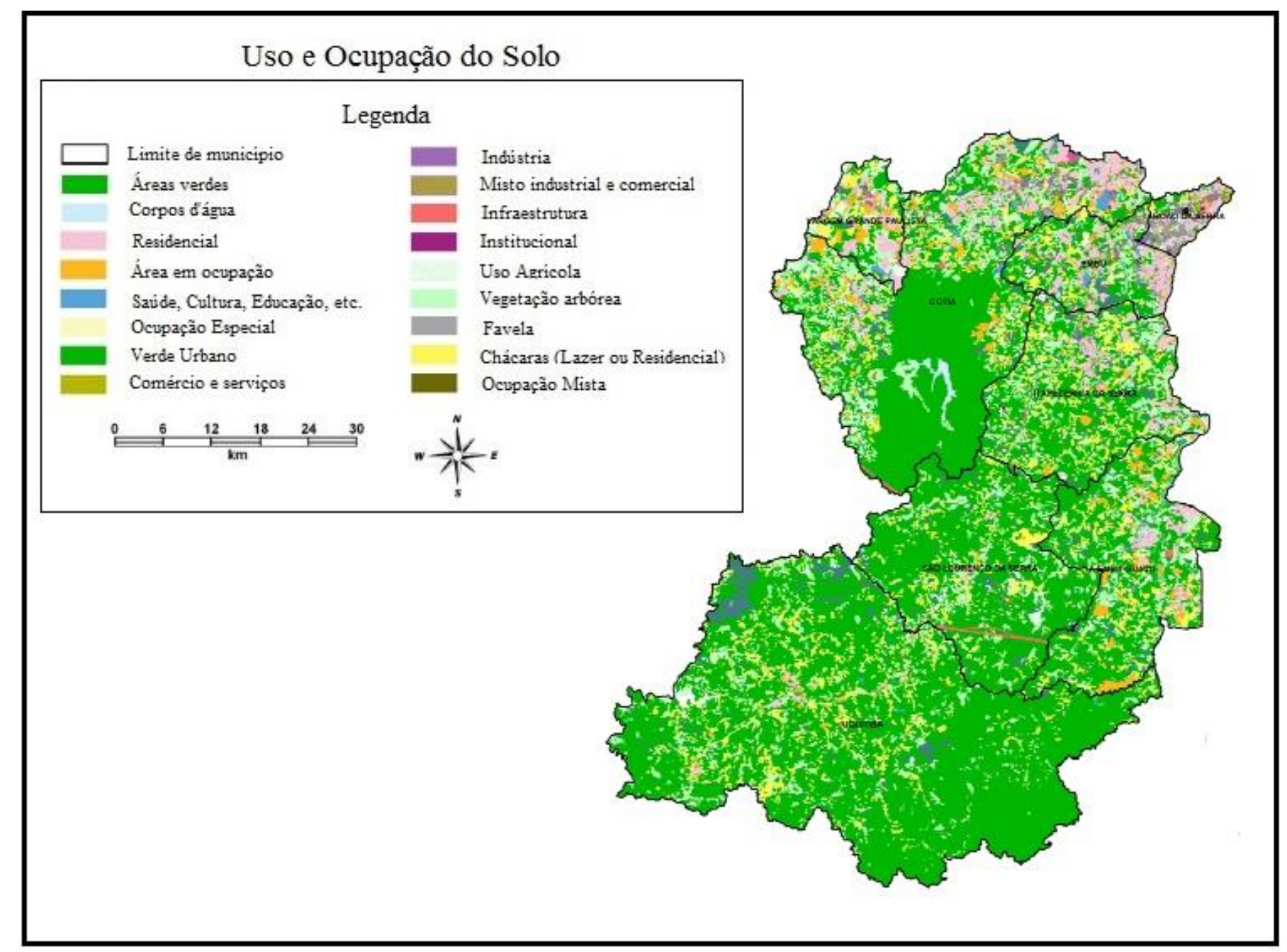

Figura 09: Mapa de Uso e Ocupação do Solo - Sub-região Sudoeste

Fonte: Empresa Paulista de Planejamento Metropolitano - EMPLASA

$$
\text { Adap. Lima, } 2014
$$


A sub-região leste (Figura 10) é a mais extensa da RMSP, constituindo mais de $35 \%$ de sua área total. Os municípios que a compõe são: Ferraz de Vasconcelos, Arujá, Guararema, Biritiba Mirim, Guarulhos, Itaquaquecetuba, Poá, Suzano, Mogi das Cruzes, Salesópolis e Santa Isabel.

Em relação ao uso do solo, o que mais chama a atenção nesta subregião é a sua heterogeneidade, compreendendo desde áreas urbanas consolidadas e em processo de verticalização, até áreas de produção agrícola especializadas ou destinadas à reserva de água para o abastecimento público.

As áreas mais densamente urbanizadas correspondem às porções oeste e noroeste, que são os setores resultantes da expansão do eixo leste do município de São Paulo. É importante também mencionar a elevada industrialização desta áreas, com destaque para Guarulhos, que concentra o segundo maior aglomerado industrial da RMSP, além do Aeroporto Internacional de Guarulhos - Governador André Franco Montoro, que atende todo o Estado de São Paulo, e confere grande importância ao município.

A porção a leste da sub-região, formada pelos municípios de Salesópolis, Guararema, Santa Isabel e Biritiba Mirim, caracteriza-se pela baixa densidade demográfica e por uma industrialização mais incipiente, com predomínio de áreas verdes e campos de cultivo.

Os investimentos do setor terciário na sub-região leste têm crescido bastante nos últimos anos, beneficiando-se da presença de um contingente populacional significativo com renda média, que compõe um importante mercado consumidor e também através da proliferação de ofertas de serviços terceirizados, tais como logística, transporte de cargas, armazenagem, limpeza, entre outros, normalmente demandados pelo setor industrial. 


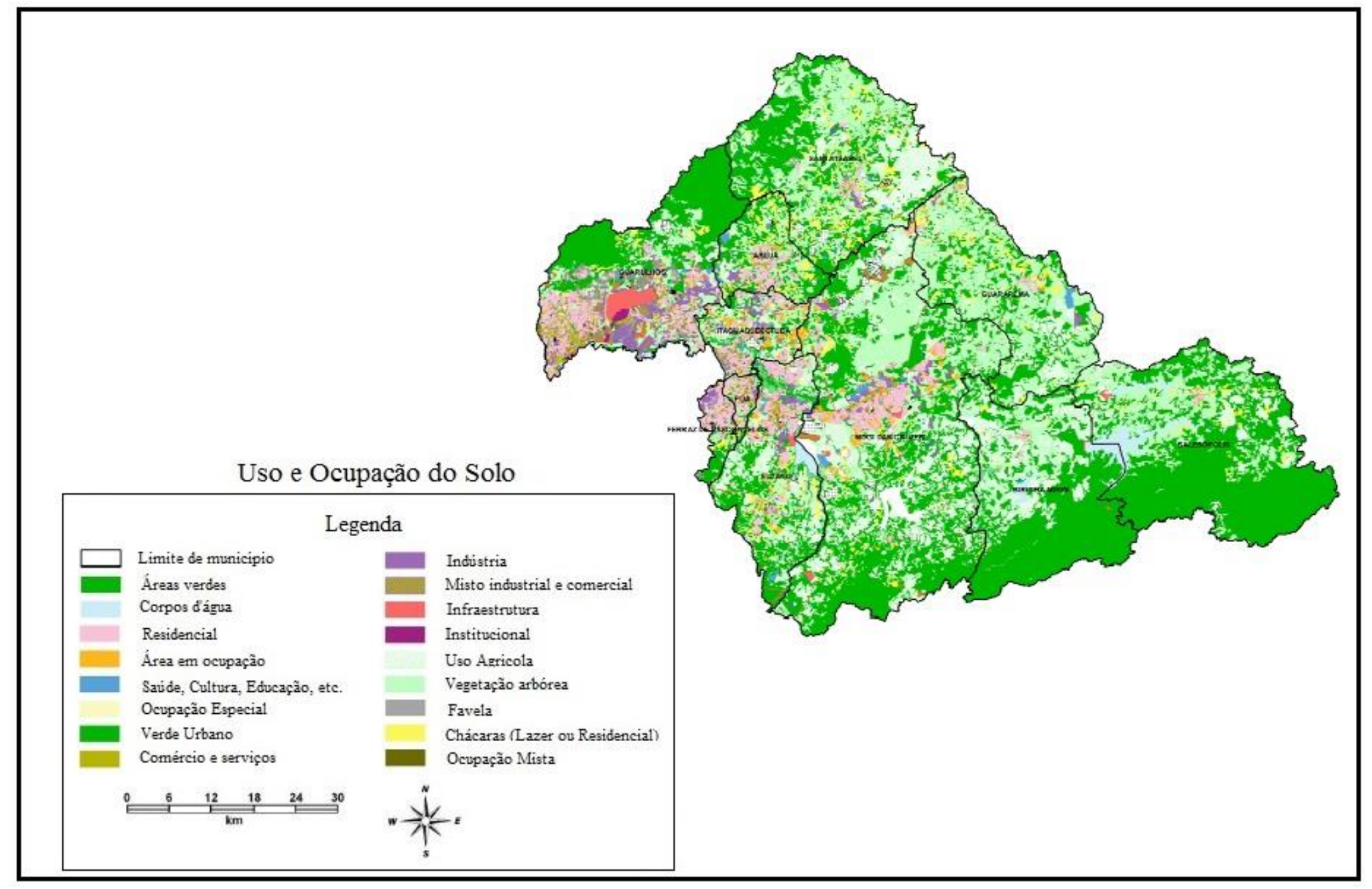

Figura 10: Mapa de Uso e Ocupação do Solo - Sub-região Leste Fonte: Empresa Paulista de Planejamento Metropolitano - EMPLASA Adap. Lima, 2014 
A sub-região sudeste (Figura 11) tem como principal característica a forte presença de indústrias automobilísticas e metalúrgicas, que se localizam às margens das Rodovias Imigrantes e Anchieta. Outra característica marcante é o elevado grau de urbanização dos municípios de São Caetano do Sul, Santo André, São Bernardo do Campo, Mauá e Diadema.

As áreas ao sul desta sub-região possuem especial importância, pois abrigam mananciais dos sistemas de abastecimento de água metropolitano, incluindo a bacia do Reservatório Billings, que ocupa uma porção significativa do território.

A sub-região sudeste abriga atualmente $13 \%$ da população da RMSP (Censo do IBGE, 2010). Seu desenvolvimento está associado ao crescimento industrial, que atraiu elevados contingentes de migrantes vindos de todo Brasil em busca de trabalho, o que resultou numa acelerada expansão urbana.

Apesar da importância do setor industrial para economia desta subregião, este vem perdendo importância nas últimas décadas, dando lugar aos setores de serviços e comércio, tendência observada em toda a RMSP. 


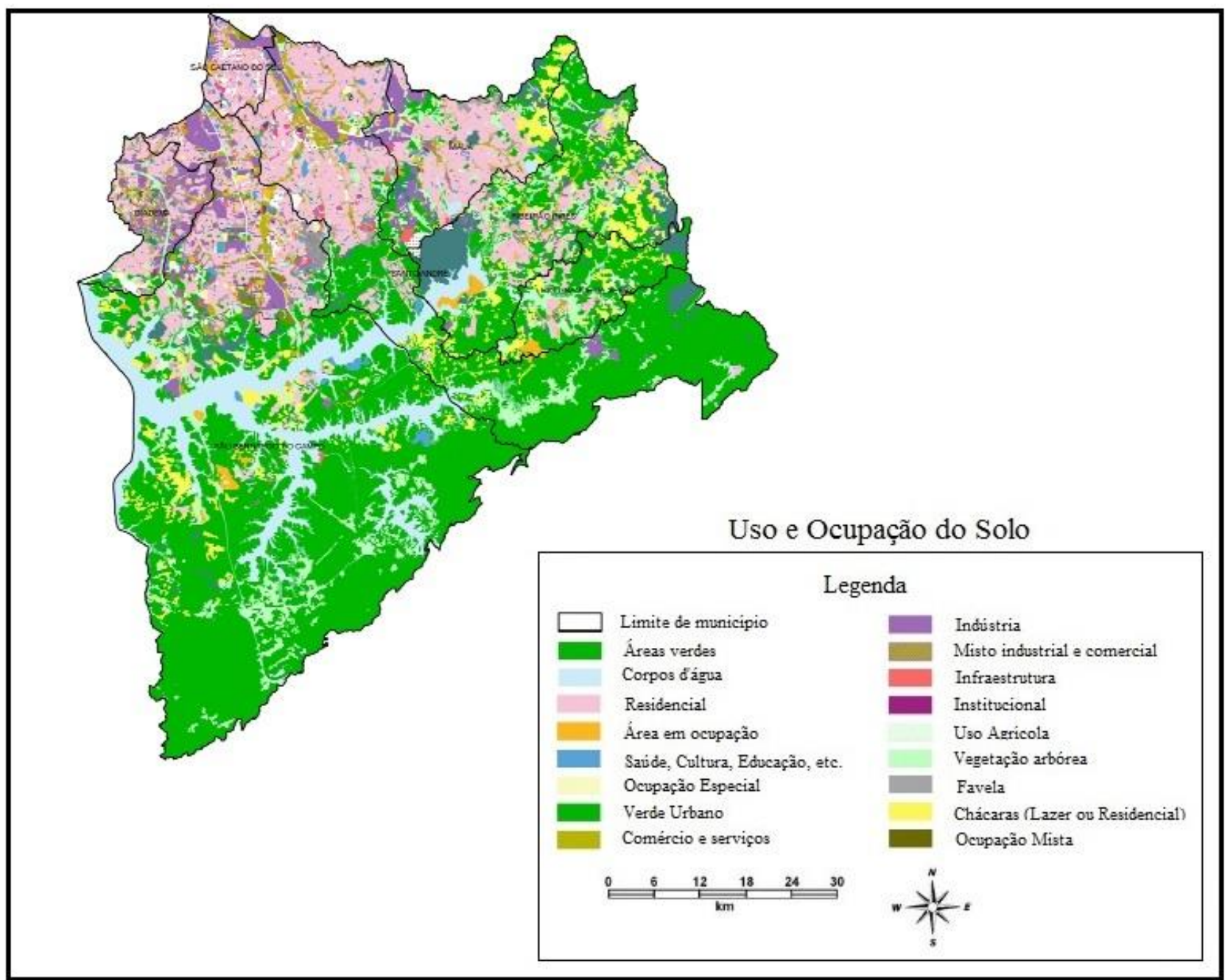

Figura 11: Mapa de Uso e Ocupação do Solo - Sub-região Leste Fonte: Empresa Paulista de Planejamento Metropolitano - EMPLASA Adap. Lima, 2014 
Abrigando quase $6 \%$ da população brasileira, o Município de São Paulo (Figura 12), capital do Estado de São Paulo, se caracteriza por suas enormes proporções territoriais e populacionais, além de sua importância econômica para todo território nacional.

Já no início do século XX São Paulo assumiu um importante papel de centro comercial, e passou a apresentar elevados índices de crescimento demográfico, que perduraram até a década de 1970. Desde então, a taxa de crescimento populacional tem se reduzido, devido a vários fatores, tais como menores índices de natalidade e refluxos do movimento migratório, devido a uma reestruturação econômica e produtiva do município.

A indústria, que antes era o principal setor econômico da capital, passou a buscar outras áreas do Estado para se instalar, devido, principalmente, ao elevado custo do solo e às altas taxas cobradas na cidade de São Paulo, o que deu lugar ao crescimento do setor terciário, que hoje é o mais importante e a base da economia do município.

O município de São Paulo apresenta uma urbanização intensa ao longo de quase todo seu território, com exceção da parte mais ao sul, onde se encontram importantes reservatórios de água, utilizados para o abastecimento metropolitano. 


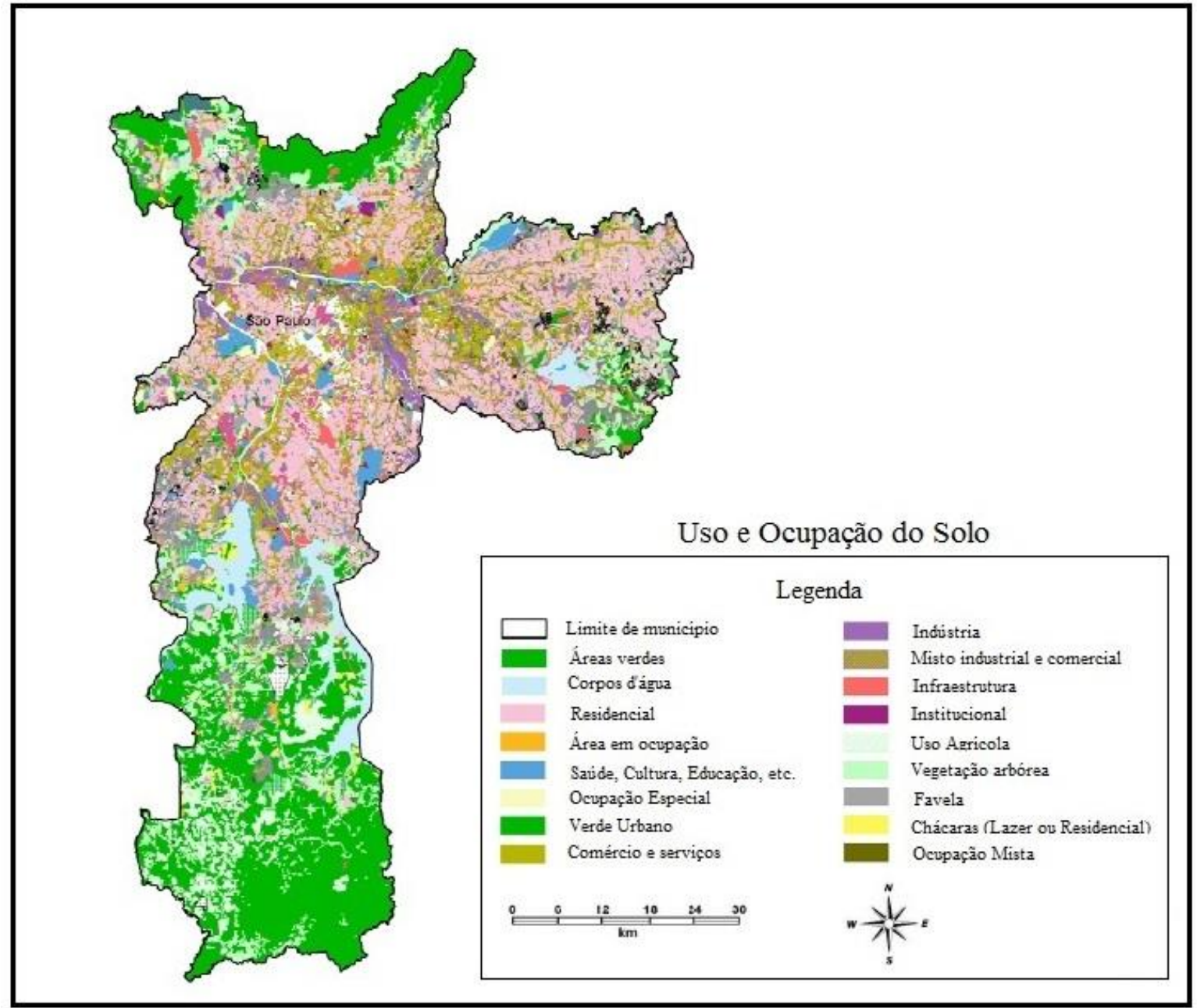

Figura 12: Mapa de Uso e Ocupação do Solo - Município de São Paulo Fonte: Empresa Paulista de Planejamento Metropolitano - EMPLASA Adap. Lima, 2014 


\subsubsection{Recursos Hídricos na Região Metropolitana de São Paulo}

A caracterização dos recursos hídricos superficiais da Região Metropolitana de São Paulo tem como principal objetivo a apresentação das bacias hidrográficas, do comportamento hidrológico das bacias e das redes de drenagens superficiais, tendo por base as informações disponíveis nos seguintes órgãos: Departamento de Águas e Energia Elétrica (DAEE), Sistema de Gerenciamento de Recursos Hídricos do Estado de São Paulo (SIGRH) e Companhia de Tecnologia e Saneamento Ambiental (CETESB). Foram consultadas também informações em outras fontes secundárias, com destaque para Plano Diretor de Macrodrenagem da bacia do Alto Tiête (DAEE, 1998).

O Plano Estadual de Recursos Hídricos (PERH), aprovado pela Lei Estadual no 9.034 de 27 de dezembro de 1994, dividiu o Estado de São Paulo em 22 Unidades de Gerenciamento de Recursos Hídricos (UGRHI) (Figura 13). As bacias hidrológicas são classificadas conforme seu uso em agropecuárias, industriais, em industrialização e de conservação.

A bacia hidrográfica vem sendo utilizada como um modelo mais abrangente de conceituar e compreender os ecossistemas, visto que os ambientes aquáticos fazem parte de sistemas maiores, que envolvem os aspectos de geologia, vegetação, clima, uso e ocupação do solo, sendo formados por um mosaico de subsistemas funcionais interligados por processos bióticos e abióticos (Henry-Silva e Camargo, 2000; Smith e Petrere Jr.; 2001; Schiavetti e Camargo, 2002; Brigante e Espíndola, 2003) e proporcionando condições para o desenvolvimento de estudos interdisciplinares, gerenciamento dos usos múltiplos e conservação (Tundisi, 2003). 
A bacia hidrográfica envolve ainda componentes estruturais e funcionais, processos biogeofísicos, econômicos e sociais, tornando-se assim uma unidade ideal para integrar esforços de pesquisa e gerenciamento, por isso vêm sendo utilizada como instrumento de percepção ambiental e atuando como um laboratório experimental para o ensino (Tundisi e Schiel, 2002; Tundisi, 2003). Além disso, o monitoramento limnológico das bacias hidrográficas tem gerado indicadores sensíveis de interações e alterações dos sistemas. Neste contexto, o monitoramento da qualidade da água é importante, pois ajuda a definir estratégias de utilização, gestão, controle e conservação (Cottingham e Carpenter, 1998).

A avaliação dos impactos e a quantificação dos processos permitem o levantamento de indicadores que venham a promover ações de gerenciamento, o qual deve ser feito em torno de dois enfoques principais; a qualidade e a quantidade das águas superficiais (Likens, 2001; Tundisi, 2008).

Outros aspectos relevantes que qualificam a bacia hidrográfica como unidade de estudo e gerenciamento são: desenvolvimento de parcerias e solução de conflitos (Tundisi e Tundisi, 1995); integração institucional, que é fundamental para o desenvolvimento sustentável; criação de um banco de dados sobre os mais diversos componentes sejam eles, econômico, social, físico e biológico e participação da população local, promovendo assim a conscientização e educação ambiental (Tundisi et al ., 1997). É importante ressaltar, que atualmente novos paradigmas têm direcionado os estudos e manejo de bacias hidrográficas, incorporando os conceitos do Contínuo Fluvial (Vannote et al ., 1980); do Pulso de Inundação (Junk et al ., 1989); da Teoria da Espiral de Nutrientes (Elwood et al ., 1985) e dos conceitos relacionados à Ecologia da Paisagem (Hansson et al ., 1995; Thorp et al , 2006). 


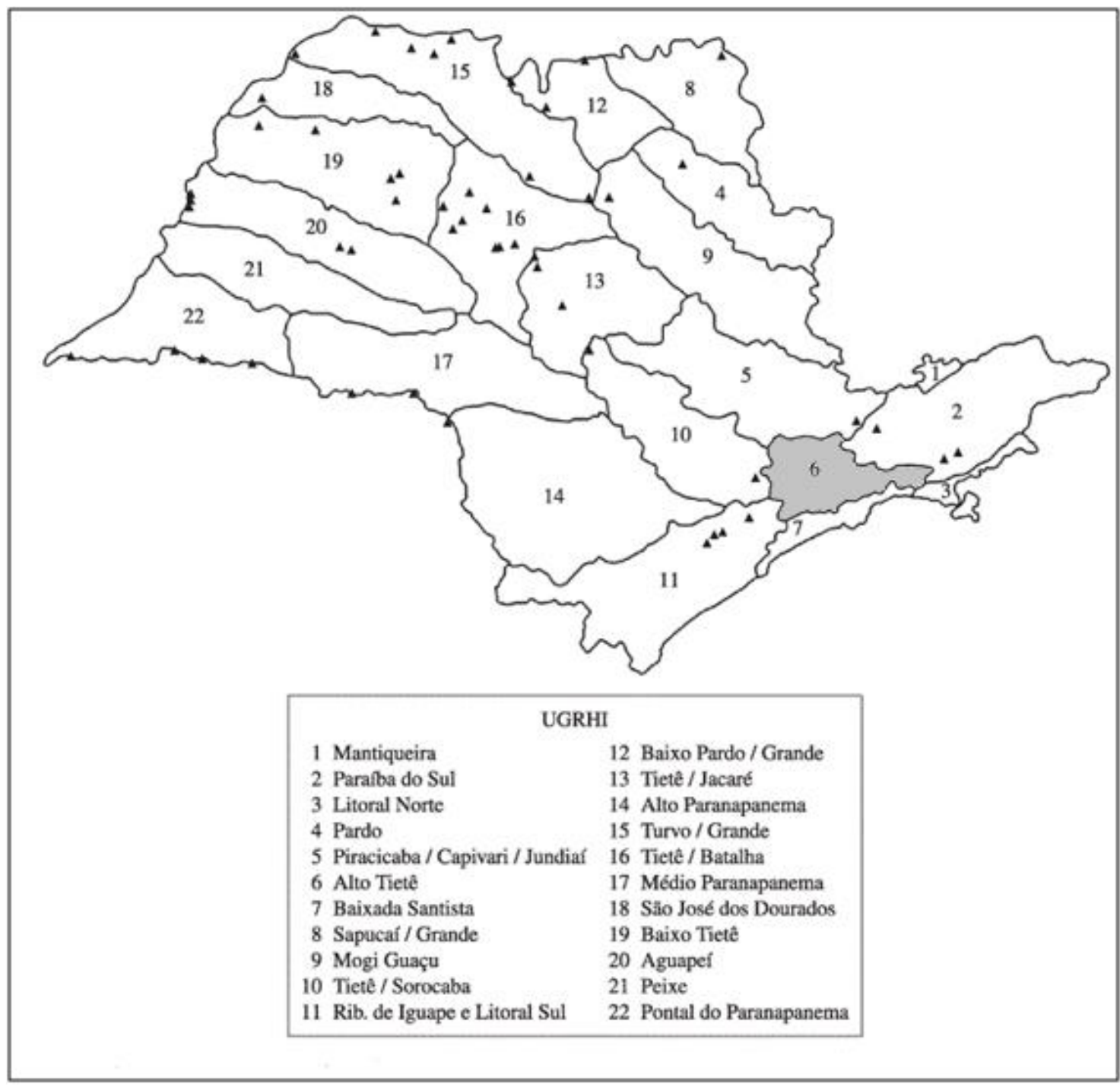

Figura 13: Unidades de Gerenciamento dos Recursos Hídricos do Estado de São Paulo

Fonte: Brazilian Journal of Biology - http://www.scielo.br Acesso em 12/03/2013

Adaptado: Lima (2014)

A Região Metropolitana de São Paulo encontra-se inserida na Unidade de Gerenciamento de Recursos Hídrico do Alto do Tietê (UGRHI 06), que está localizada inteiramente no Estado de São Paulo, no Planalto Atlântico, a uma altitude média de 750 metros acima do nível do mar. Essa unidade de gerenciamento é classificada como de uso industrial, possui uma superfície de 5.985 km² e engloba 34 municípios sendo formada pelos rios Tiête, Tamanduateí e Pinheiros. Destacam-se ainda os reservatórios: Edgard de Souza, Ribeirão do 
Carmo, Jundiaí, Ponte Nova, Rio das Pedras, Paraitinga, Biritiba, Taiaçupeba, Billings, Paiva Castro, Pirapora, e Guarapiranga.

Cabe ressaltar que a bacia do Alto Tietê é considerada crítica em relação a sua disponibilidade hídrica superficial de boa qualidade para o consumo nos diferentes usos urbanos, sendo necessária a importação de água de outras bacias para compensar a demanda e regularizar o abastecimento.

A UGRHI 06 possui 23 municípios com índices de perda no sistema de abastecimento acima de 30\%, apontando para o risco de rebaixamento acentuado da superfície do lençol subterrâneo do aquífero sedimentar. A área é crítica com relação ao risco de poluição das águas subterrâneas. Em média, essa unidade de gerenciamento exporta cerca de $15 \mathrm{~m}^{3} / \mathrm{s}$ de água para a Baixada Santista, para geração de energia da usina Henry Borden e importa cerca de $32,5 \mathrm{~m}^{3} / \mathrm{s}$, principalmente do Sistema Cantareira.

Quanto aos processos erosivos, os mesmos ocorrem predominantemente nas áreas periféricas das cidades pertencentes a Região Metropolitana de São Paulo e seu desenvolvimento decorre do processo de expansão urbana acelerada. Verifica-se alta suscetibilidade a inundações ao longo dos rios Tietê, Tamanduateí, Aricanduva, Pirajussara e afluentes, e em diversos pontos críticos da RMSP. Considera-se que, quanto maior a densidade de elementos de drenagem de primeira ordem, maior será a suscetibilidade relativa aos processos degradacionais, ou seja, áreas mais favoráveis à instalação de processos erosivos lineares, como sulcos e ravinas. Portanto, quanto maior a densidade de elementos de drenagem, maior será o espaço a ser definido como preservação permanente.

No que se refere à disponibilidade hídrica, uma grande quantidade de indústrias, condomínios e empreendimentos isolados utilizam os aquíferos como 
fonte alternativa ou primária para suprirem suas necessidades diárias de água. As demandas de água do Estado atingem, aproximadamente, $354 \mathrm{~m} 3 / \mathrm{s}$, sendo $87 \mathrm{~m}^{3} / \mathrm{s}$ para abastecimento urbano, $154 \mathrm{~m}^{3} / \mathrm{s}$ para irrigação e $112 \mathrm{~m}^{3} / \mathrm{s}$ para abastecimento industrial. Cerca de $17 \%$ da disponibilidade estadual são utilizados e $8 \%$ consumidos durante esses usos por evapotranspiração, por incorporação aos produtos ou absorção pelas culturas irrigadas. Na UGRHI 06, 0 balanço disponibilidade versus demanda é desfavorável, sendo cerca de $55 \%$ da disponibilidade hídrica utilizada e $9 \%$ consumida. O comprometimento de quase um terço da água disponível com a poluição fez com que a reversão de águas de outras unidades se tornasse inevitável, devendo aumentar no futuro.

Devido à sua localização (planalto com baixos declives) e o intenso processo de urbanização, intensificado na década de 60, a UGRHI 06 sofre de problemas vinculados à inundações. Assim, desde a década de 60 vêm sendo realizados estudos, projetos e obras com o intuito de combater as enchentes, e em 1998, através de uma abordagem integrada dos problemas em todas as principais sub-bacias da bacia hidrográfica do Alto Tiête, foi elaborado o Plano Diretor de Macrodrenagem.

O Plano Diretor de Macrodrenagem visa, em síntese, diagnosticar os problemas existentes ou previstos no horizonte de projeto a determinar, do ponto de vista técnico-econômico e ambiental, as soluções mais interessantes.

\subsubsection{Histórico do Abastecimento de Água na Região Metropolitana de São Paulo.}

Durante mais de trezentos anos o abastecimento de água para população em São Paulo foi precário, e em geral era realizado de maneira 
individual, com a retirada a partir das fontes do rio Tamanduateí e dos poucos chafarizes existentes.

De acordo com Custódio (2012), por muitas décadas o Poder Público realizou pouquíssimas obras para melhoria do abastecimento de água para cidade, e o que se verificava eram fontes insalubres e chafarizes pouco conservados e em pequeno número para atender uma população que crescia rapidamente.

Alguns optavam pela compra da água dos chamados aguadeiros portugueses, mas o preço era alto, e poucos podiam recorrer a esta solução.

Já nas últimas décadas do século XIX, o café, a construção de novas ferrovias e a chegada de um grande número de imigrantes estrangeiros realizaram grandes transformações em São Paulo e a questão da falta de água se agravou bastante. Para tentar solucionar parte do problema, entre os anos de 1873 e 1875 foram construídos alguns novos chafarizes, porém a deficiência continuava e as disputas também.

Existiam muitas controvérsias em relação às melhores soluções, enquanto alguns grupos defendiam a adução dos mananciais próximos à cidade, outros alegavam que as águas dos rios de São Paulo eram a causa das epidemias e que a adução teria que ser realizada a partir de rios mais distantes da capital.

Por fim, em 1875 o Poder Público contratou os serviços da Companhia Cantareira de Águas e Esgotos, formada por um grupo de empresários com o objetivo de prestação de serviços de saneamento básico durante trinta anos, com a utilização das águas dos mananciais da Serra da Cantareira, no entanto, a demanda crescia juntamente com a incapacidade de atendê-la. Em 1893 a Companhia passou para as mãos do poder público estadual. 
Foi criada, então, pelo governo do Estado a Repartição dos Serviços Técnicos de Água e Esgoto, que mais tarde passou a se chamar apenas Repartição de Águas e Esgotos (R.A.E), e que atuou até meados do século XX.

As atividades industriais, comerciais e de serviços, a influência da Light and Power Co. e da Companhia City (BACELLI, 1982), construtora de vários bairros de São Paulo, o aumento dos transportes (individuais e coletivos), a verticalização das áreas mais centrais, a construção de grandes avenidas, inclusive marginais aos rios Tietê e Pinheiros (Plano de Avenidas do Prefeito Prestes Maia: 1938 - 1945) (Figura 14), o surgimento de novos bairros, muitas vezes precários e distantes, e o crescimento vegetativo da população em paralelo com um surpreendente processo migratório de pessoas de diversos estados brasileiros em direção à São Paulo geraram um crescimento urbano muito rápido, fruto da reformulação da divisão regional do trabalho promovida a partir de políticas desenvolvimentistas a favor da região Sudeste. Neste período, a mancha urbana ultrapassou a rio Pinheiros a oeste, o rio Tietê a norte, o rio Aricanduva a leste e atingiu as proximidades das represas Billings e Guarapiranga, localizadas mais ao sul.

Os problemas de saneamento básico se agravaram, e a população buscava formas alternativas de solucionar tais dificuldades, procedendo à perfuração de poços e fossas sépticas. Preocupado com a situação, o governo do Estado realizou um importante conjunto de obras, por intermédio da Repartição de Águas e Esgotos (R.A.E), contudo os interesses da população, em busca de melhores condições de vida, ficavam em segundo plano quando se tratava do setor energético-industrial na Bacia Hidrográfica do Alto Tietê, que neste período já passava por progressivo comprometimento de suas águas por esgotos domésticos e dejetos industriais. 


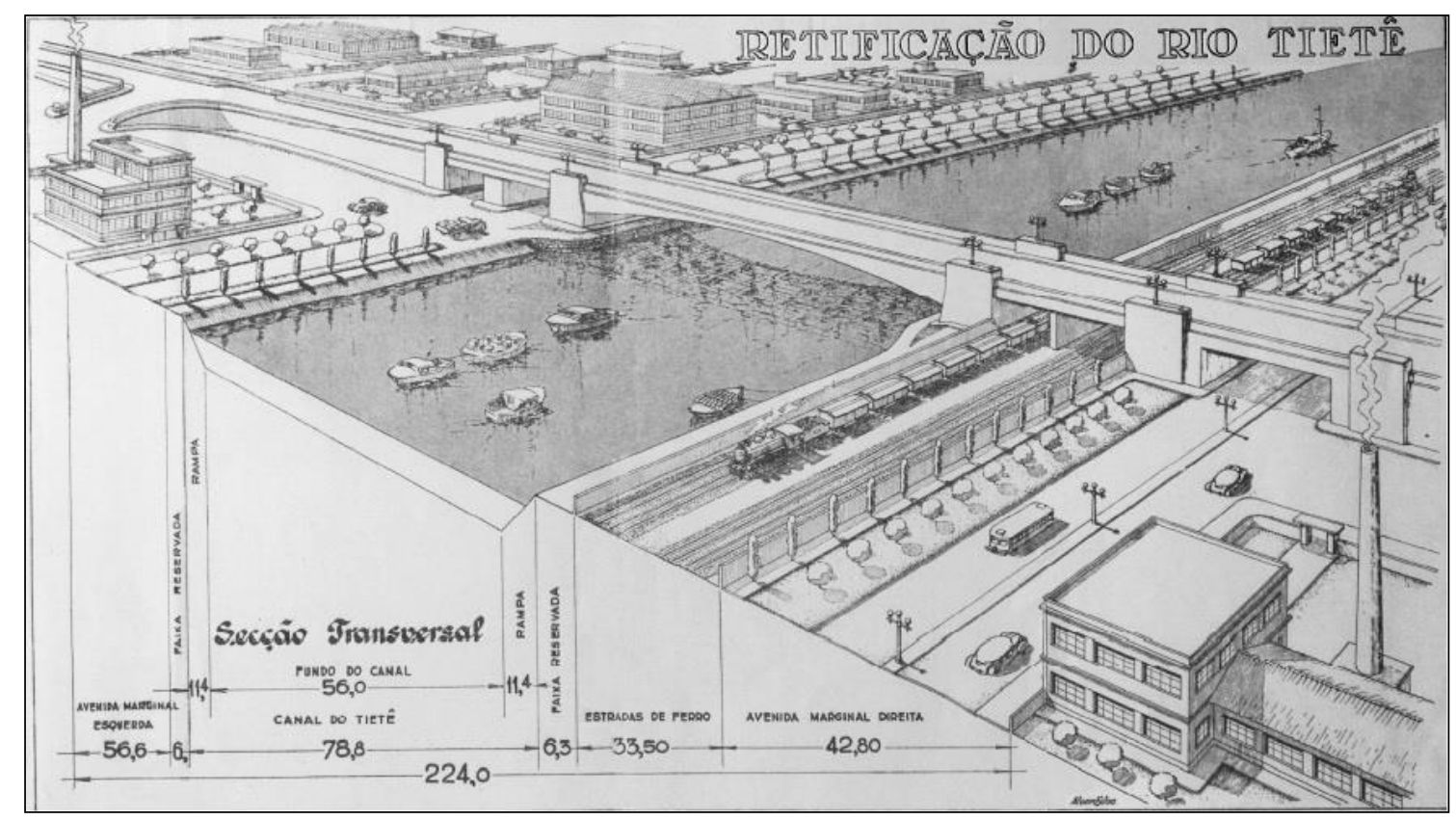

Figura 14: Proposta de Retificação do Rio Tietê e Construção de Avenidas Marginais Prefeito Prestes Maia - Década de 1940.

Fonte: Plano Diretor de Macrodrenagem da Bacia do Alto Tietê - DAEE

Na década de 1950 encerraram-se muitas atividades relacionadas aos rios de macrodrenagem como os clubes recreativos, as hortas, a retirada de materiais para a construção civil, como areia e cascalho, a navegação, entre outras, pois a retificação dos rios e as obras das vias marginais (Figura 14) comprometiam os múltiplos usos da água.

A prestação de serviços de saneamento básico para metrópole estava comprometida, e por conta de problemas burocráticos a estrutura da Repartição de Águas e Esgotos apresentava sérios problemas, que foram minimizados com a criação em 1954 do Departamento de Águas e Esgotos (D.A.E), que tinha, de acordo com Custódio (2012, p. 76) "[...] autonomia administrativa para tratar dos serviços de água e esgotos em escala regional, ou seja, para o atendimento de São Paulo e dos municípios vizinhos de Santo André, São Bernardo do Campo, São Caetano do Sul (Região do $A B C$ ) e Guarulhos." 
A retirada das águas do reservatório Guarapiranga continuaram, somando-se agora às da represa Billings, e teve início as obras para construção do sistema Cantareira, que duraram até finais do século XX.

Toniolo (1986, p.363) afirma que como reflexo das reformulações que ocorreram no executivo federal, no Estado de São Paulo foi criada a Companhia Metropolitana de Água de São Paulo (COMASP), após uma reformulação do Departamento de Águas e Esgotos (D.A.E) em 1968. A COMASP era uma empresa de economia mista, com atuação em nível metropolitano e cujo objetivo era tratar e vender água potável aos então 37 municípios que compunham a ainda não instituída Região Metropolitana de São Paulo. Por fim, em 1971, foi criado o Plano Nacional de Saneamento (PLANASA), vinculando a política de saneamento básico urbano à política habitacional urbana.

O atendimento às demandas urbanas de água da Região Metropolitana de São Paulo, que se caracterizam como usos doméstico, industrial, comercial, energia, entre outros, levou à construção de várias obras na Bacia do Alto Tietê. Atualmente são oito sistemas produtores de água (SPAs) e seis sistemas de tratamento de esgotos (STEs) ${ }^{4}$.

\subsubsection{O Abastecimento de Água na Região Metropolitana de São Paulo - Cenário Atual.}

A mancha urbana do que hoje corresponde a Região Metropolitana de São Paulo sofre com um constante processo de expansão. Atualmente a área mais urbanizada ocupa inteiramente a Bacia Sedimentar e apresenta intensa impermeabilização e sérios problemas de inundação.

\footnotetext{
${ }^{4}$ SABESP: Sistemas Produtores de Água e Sistemas de Tratamento de Esgotos. Disponível em www.sabesp.com.br. Acesso em 12/03/2013
} 
O conjunto hidrográfico da RMSP corresponde à Bacia Hidrográfica do Alto Tietê, que se localiza inteiramente no estado de São Paulo. De fato, cerca de 70\% da Região Metropolitana está sobre esta bacia (Figura 15) e, portanto, é estreita a relação entre ambas às escalas de abordagem.

Na Bacia Hidrográfica do Alto Tietê localizam-se grandes represas, construídas para distintos fins, tais como, abastecimento de água, geração de energia hidroelétrica e regularização de vazão. As represas que mais se destacam são Billings, Guarapiranga, Jundiaí, Taiaçupeba, Ponte Nova, Biritiba e Paraitinga.

Criado pela Lei Estadual de Recursos Hídricos, no 7.663 em 30 de dezembro de 1991, o Comitê da Bacia Hidrográfica do Alto Tietê é o responsável pelas decisões de como gerenciar a água na Região Metropolitana. Todas as questões ligadas à utilização dos recursos hídricos devem ser questionadas e decididas neste fórum, constituído por representantes do Estado, dos 34 municípios da Bacia e das entidades da sociedade civil, com participação paritária.

De acordo com seu estatuto, o Comitê da Bacia Hidrográfica do Alto Tietê está dividido em cinco sub-bacias, que agrupam os municípios em subregiões administrativas, com organização similar e gestão descentralizada, submetida ao comitê central.

Na RMSP o abastecimento de água é realizado de maneira integrada, e é constituído por oito complexos que são responsáveis pela produção de 67 mil litros de água por segundo, para abastecer 32 municípios atendidos pela SABESP e outros sete que compram água por atacado (Santo André, São Caetano do Sul, Guarulhos, Mogi das Cruzes, Diadema, Santa Isabel e Mauá) (Figura 16). 


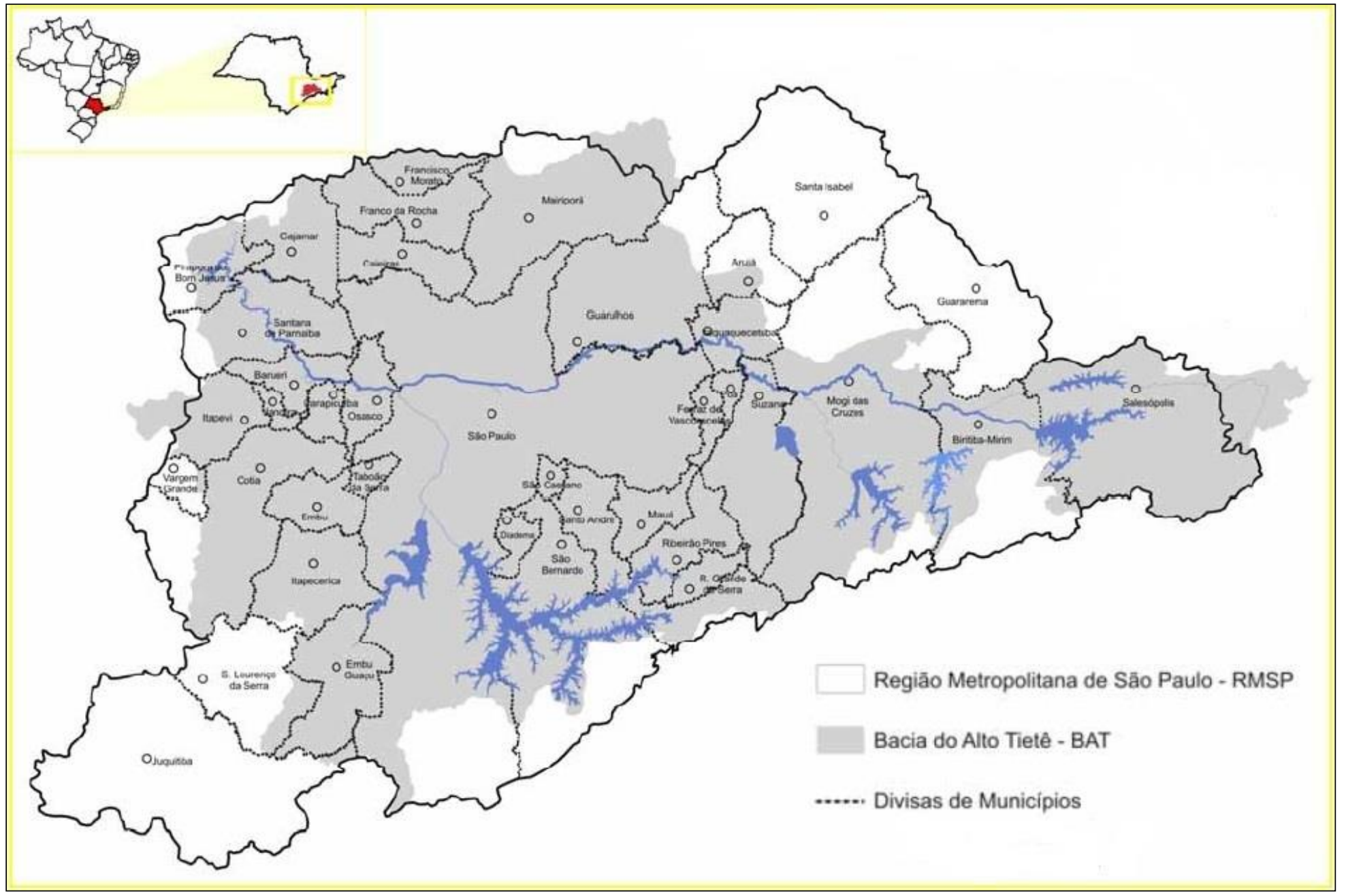

Figura 15: Bacia Hidrográfica do Alto Tietê

Fonte: Empresa Paulista de Planejamento Metropolitano - EMPLASA 
A SABESP constitui peça-chave para o fornecimento de água para a região metropolitana. Com exceção de algumas autarquias municipais, a RMSP é em larga escala atendida por esta companhia. Através de interligações dos diversos reservatórios que abastecem a região metropolitana (todos monitorados pela SABESP), o desenho final é o Sistema Adutor Metropolitano (SAM). O SAM equaliza o fornecimento para todas as cidades conectadas aos Sistemas produtores de água voltados para o abastecimento da Grande São Paulo (WALDMAN, 2005).

O Sistema Produtor é constituído por mananciais de captação, e o suprimento de água potável para a Região Metropolitana de São Paulo é efetuado pelo Sistema Integrado de Abastecimento de Água (SIAA), composto por sistemas produtores de água que utilizam, basicamente, mananciais de superfície.

O Sistema Cantareira, localizado a norte da Região Metropolitana de São Paulo, é o maior sistema de abastecimento de água da América Latina. Contribui com quase $50 \%$ do volume de água para o abastecimento da RMSP e é o responsável pela reversão de águas da Bacia do Rio Piracicaba para a do Alto Tietê.

Esse sistema é composto por cinco reservatórios produtores de água (Jaguari, Jacareí, Cachoeira, Atibainha e Juquery), túneis e canais subterrâneos de interligação e transferência de uma represa para outra, uma estação elevatória (Elevatória de Santa Inês), um reservatório de regularização da vazão (reservatório Águas Claras) e uma estação de tratamento (ETA do Guaraú). Os mananciais da Cantareira localizados na área da Região Metropolitana são protegidos pela Lei de Proteção dos Mananciais n 898/75. 
O Sistema Guarapiranga é o segundo maior da Região Metropolitana, compreende a represa de Guarapiranga, cujos principais contribuintes são os rios Embu-Mirim, Embu-Guaçu e Parelheiros, pelas transferências dos rios Capivari e Monos, na vertente marítima, e pelas ramificações da margem esquerda da represa Billings.

Ao final do ano 2000, foram acrescidas ao Sistema Guarapiranga as águas provenientes da reversão do rio Taquacetuba, que é um afluente da represa Billings.

A situação desse manancial é preocupante, pois a qualidade das águas dos rios e da represa só tem piorado no decorrer dos anos com o aumento do despejo de esgoto doméstico. Uma grande área de preservação permanente (APP) foi ocupada e a população que vive próximo à represa tem aumentado rapidamente nos últimos anos.

O Sistema Rio Grande (Billings) utiliza as águas do braço do Rio Grande, situado na margem direita da Represa Billings, e abastece os municípios de Diadema, São Bernardo do Campo e uma parte de Santo André.

A Represa Billings se caracteriza por ser o maior reservatório da Região Metropolitana de São Paulo, e está localizada a sudoeste da capital, tendo como limites, a oeste a sub-bacia da Guarapiranga e ao sul a Serra do Mar.

Um dos principais problemas existentes no território da sub-bacia hidrográfica da Billings é a substituição da cobertura florestal nativa (Mata Atlântica), fundamental para a produção de água em quantidade e qualidade adequadas ao abastecimento público, por áreas ocupadas por atividades humanas, essa área mesmo protegida pela Lei de Proteção dos Mananciais desde a década de 70, vem sofrendo ao longo dos últimos anos as consequências de um processo acelerado de ocupação irregular e destrutiva. 


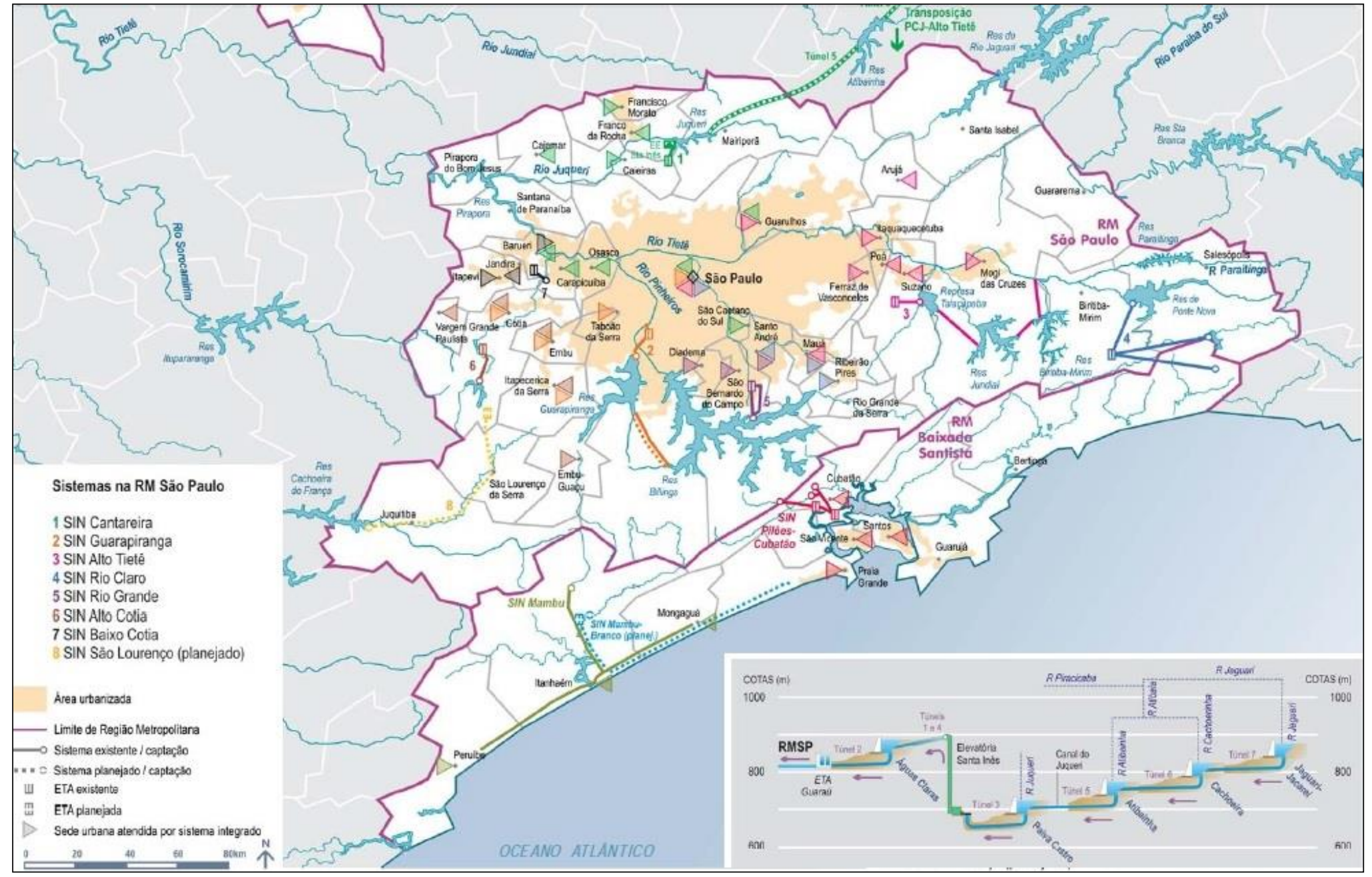

Figura 16: Sistemas de Abastecimento na Região Metropolitana de São Paulo Fonte: Agência Nacional de Águas (ANA) 
O Sistema Rio Claro e Ribeirão da Estiva utiliza águas do Rio Claro, pertencente à Bacia do Alto Tietê e do Rio Guaratuba. Está localizado a aproximadamente $70 \mathrm{~km}$ da capital paulista, abastecendo Sapopemba, Ribeirão Pires e partes dos municípios de Mauá e Santo André.

O Sistema Cotia se divide em dois subsistemas denominados Alto Cotia e Baixo Cotia, e compõe-se das represas Pedro Beicht, Isolina e Graça. Desde o ano 2000 o sistema conta com a transferência de 800 litros por segundo provenientes do Sistema Guarapiranga. Também operam de maneira parcialmente integrada os sistemas Alto Tietê e Rio Claro

Os subsistemas Baixo Cotia e Alto Cotia utilizam as águas do Rio Cotia, e abastecem os municípios de Barueri, Jandira, Itapevi, Cotia, Vargem Grande Paulista, Embu, Itapecirica da Serra e Embu-Guaçu. As águas captadas pelo Sistema Baixo Cotia não são de boa qualidade devido ao lançamento de efluentes domésticos e industriais a montante das captações.

O Sistema Produtor Alto Tietê (SPAT) é constituído pelos reservatórios Ponte Nova, Taiaúpeba, Jundiaí, Biritiba Mirim e Paraitinga. Os reservatórios são interligados por um sistema de túneis e canais, com o objetivo de aumentar a captação de água para o abastecimento da RMSP. Esse processo denomina-se sistema em cascata e está em funcionamento desde junho de 1999.

Muitas 'dessas áreas provedoras se localizam a grandes distâncias da Região Metropolitana de São Paulo, e exigem a construção de enormes obras de infraestrutura para sua adequada captação, o que gera elevados custos para população.

Na avaliação realizada pela Agência Nacional de Águas (ANA) desses sistemas produtores, à exceção do Ribeirão de Estiva, todos requerem ampliações ou melhorias que assegurem o abastecimento de água para a RMSP 
nos horizontes considerados. Nesse contexto, destacam-se as seguintes obras de caráter mais imediato: reforço do Sistema Alto Tietê, com aumento de $5,9 \mathrm{~m}^{3} / \mathrm{s}$; aumento do bombeamento para o reservatório Biritiba $\left(9 \mathrm{~m}^{3} / \mathrm{s}\right)$; fechamento do reservatório Taiaçupeba; aumento de $1,7 \mathrm{~m}^{3} / \mathrm{s}$ do Sistema Guarapiranga e finalmente a implantação de captação no rio Juquiá (Sistema São Lourenço) com aumento de $4,7 \mathrm{~m}^{3} / \mathrm{s}$.

Esse conjunto de melhorias previstas totaliza, de acordo com a Agência Nacional de Águas (ANA), cerca de R\$ 4 bilhões em investimentos, e em complementação a esses investimentos, registra-se a necessidade de uma série de obras de melhoria no Sistema Adutor Metropolitano (SAM). 


\section{Análises das Séries Históricas dos Dados de Precipitação da Região Metropolitana de São Paulo}

\subsection{Levantamento e análise estatística das Séries de Dados}

Para realização deste trabalho foram levantadas 10 (dez) séries de dados de precipitação pluviométrica, registradas nos Postos Pluviométricos da RMSP e nas Estações Meteorológicas monitoradas pelo INMET.

Procurou-se obter séries confiáveis, com nenhuma ou poucas falhas, com o cuidado de que perfizessem no mínimo 30 anos de dados e que estivessem atualizadas até o ano de 2013.

Tendo em vista a dificuldade de encontrar séries que atendessem a estes critérios (séries longas e com poucas falhas na RMSP), foram selecionados apenas sete Postos Pluviométricos (Fazenda São Bento, Santa Isabel, Ponte Nova, Belo Monte, Juquitiba, Cachoeira da Graça e Baixo Cotia) e três Estações Meteorológicas (IAG/USP, Mirante de Santana e Guarulhos) (Tabela 02).

A localização dos Postos Pluviométricos e das Estações Meteorológicas utilizados para essa pesquisa são mostradas nas figuras 17 e 18 .

Os dados primários utilizados nessa fase da pesquisa foram os dados diários de precipitação, que posteriormente foram calculados e deram origem aos valores de precipitação mensal (Apêndice 01), sazonal e anual. Também com os dados diários das três Estações Meteorológicas foi possível realizar uma análise da frequência de dias de chuvas e do aumento dos casos de precipitações com valores superiores a $25 \mathrm{~mm}$.

No caso dos postos mais antigos, a leitura dos pluviômetros é realizada todos os dias no mesmo horário (normalmente no início da manhã) por um 
operador, já nos mais modernos a leitura é automática, e os valores registrados são enviados por uma rede telemétrica para os órgãos responsáveis.

Independente do tipo de leitura dos equipamentos é possível que ocorram erros, que geram falhas nas séries de dados. Tucci et al (2007) elenca alguns dos erros mais comuns que podem ser encontrados nas observações: danificação do aparelho, problemas mecânicos nos registradores dos gráficos, preenchimento errado da caderneta de campo, soma errada do número de provetas quando a precipitação é alta, valores estimados (quando o observador não se encontra no lugar no ato da leitura) e obstrução dos aparelhos pelo crescimento da vegetação ou outros fatores.

Assim, antes de utilizar os dados das séries, é necessário realizar uma análise prévia em busca de possíveis falhas e empregar métodos estatísticos para o preenchimento e análise de consistência dos dados. 
Tabela 02: Estações Meteorológicas e Postos Pluviométricos selecionados

\begin{tabular}{|c|c|c|c|c|c|c|c|}
\hline \multicolumn{8}{|c|}{ Estações Meteorológicas e Postos Pluviométricos } \\
\hline Nome & Município & Código & Bacia & Altitude & Latitude & Longitude & $\begin{array}{c}\text { Período dos } \\
\text { dados }\end{array}$ \\
\hline FAZENDA SÃO BENTO & ARUJÁ & 2346029 & RIO PARANÁ & 690 & $23 \div 26^{\prime}$ & $46017^{\prime}$ & $1962-2013$ \\
\hline SANTA ISABEL & SANTA ISABEL & 2346019 & ATLÂNTICO,TRECHO LESTE & 690 & $23 \div 20^{\prime}$ & $46014^{\prime}$ & $1941-2013$ \\
\hline PONTE NOVA & SALESÓPOLIS & 2345049 & RIO PARANÁ & 800 & $23034^{\prime}$ & $45058^{\prime}$ & $1967-2013$ \\
\hline MONTE BELO & ITAQUAQUECETUBA & 2346040 & RIO PARANÁ & 790 & $23 \div 29^{\prime}$ & $46 \div 22^{\prime}$ & $1943-2013$ \\
\hline JUQUITIBA & JUQUITIBA & 2347051 & ATLÂNTICO, TRECHO SUDESTE & 680 & $23 \div 56^{\prime}$ & $47004^{\prime}$ & $1947-2013$ \\
\hline CACHOEIRA DA GRAÇA & COTIA & 2346052 & RIO PARANÁ & 880 & $23 \div 39^{\prime}$ & $46057^{\prime}$ & $1936-2013$ \\
\hline BAIXO COTIA & BARUERI & 2346002 & RIO PARANÁ & 730 & 23은 & $46 \div 52^{\prime}$ & $1937-2013$ \\
\hline MIRANTE DE SANTANA & SÃO PAULO & 83781 & TIETÊ & 792 & $23 \div 30^{\prime}$ & $46037^{\prime}$ & $1961-2013$ \\
\hline GUARULHOS & GUARULHOS & 83075 & RIO PARANÁ & 765 & $23 \div 26^{\prime}$ & $46 \div 281$ & $1983-2013$ \\
\hline IAG & SÃO PAULO & 83004 & RIO PARANÁ & 800 & $23037^{\prime}$ & $46039^{\prime}$ & $1933-2013$ \\
\hline
\end{tabular}

Org. Lima, 2015 


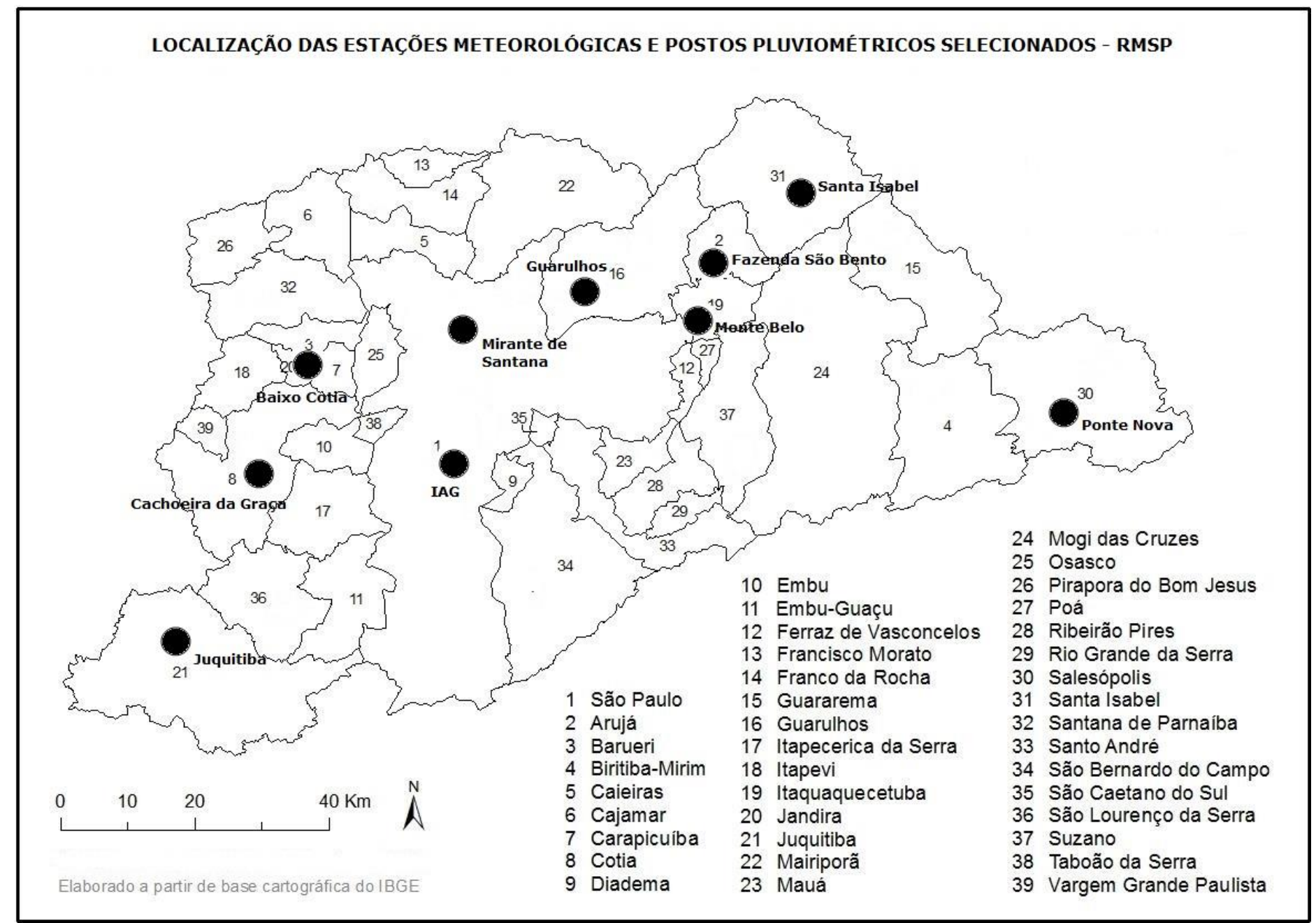

Figura 17: Localização das Estações Meteorológicas e Postos Pluviométricos Selecionados - RMSP

Fonte da Base Cartográfica: IBGE

Adap.: Lima, 2014 


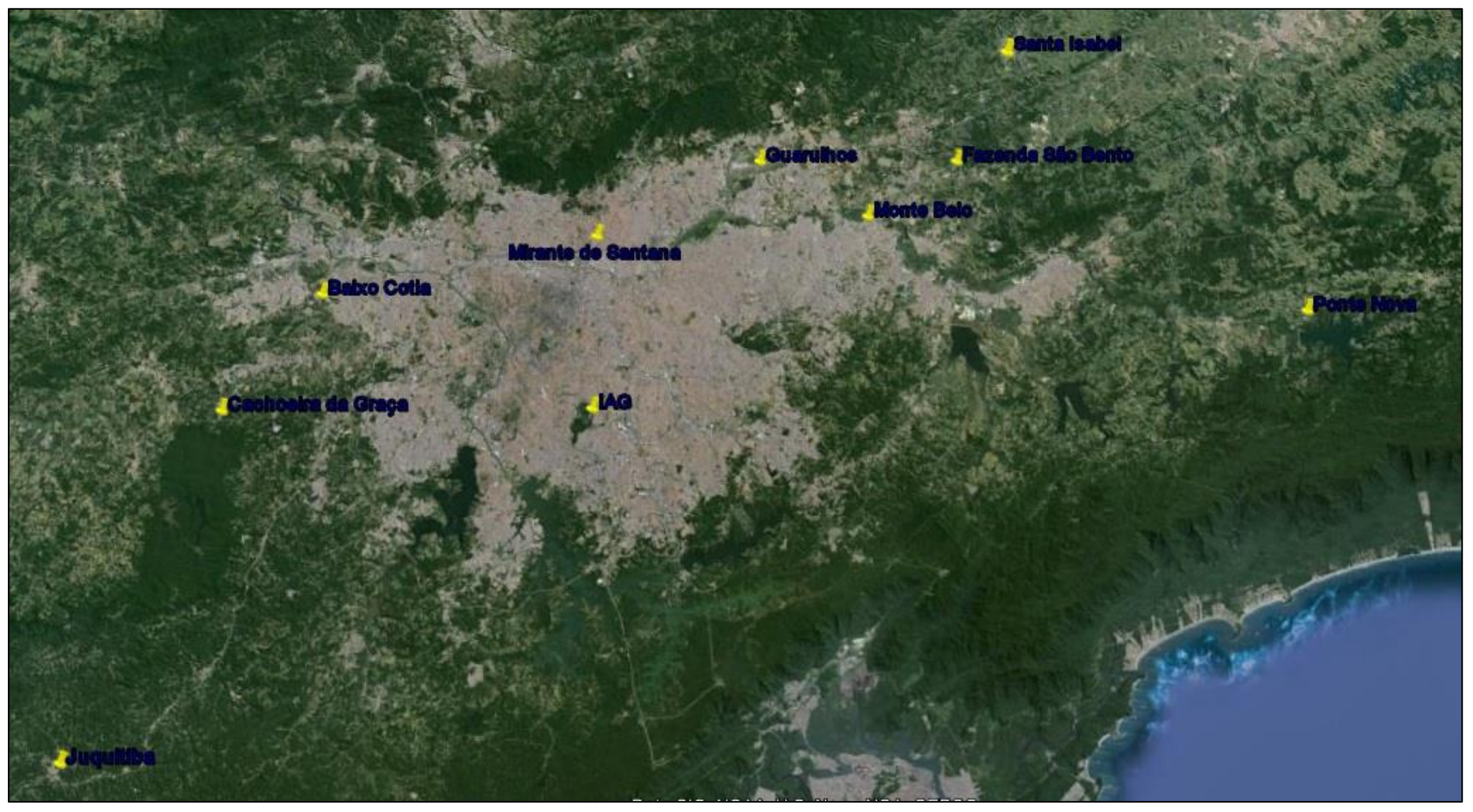

Figura 18: Localização e entorno dos Postos Pluviométricos e Estações Meteorológicas selecionada.

Fonte: Google Earth, 2015 
A fim de corrigir os erros encontrados, inicialmente foi aplicado o Método de Ponderação Regional apresentado por Bertoni e Tucci (2007), que consiste no preenchimento dos períodos com falhas a partir dos dados de pelo menos outras três estações vizinhas, que possuam no mínimo dez anos de dados.

O método é aplicado através da equação:

$$
y_{c}=\left[\left(\frac{x_{1}}{x_{m 1}}\right)+\left(\frac{x_{2}}{x_{m 2}}\right)+\left(\frac{x_{3}}{x_{m 3}}\right)\right] \cdot y_{m}
$$

Onde: $\boldsymbol{Y}$ é o posto que possui a falha, $\boldsymbol{y}_{\boldsymbol{c}}$ é a precipitação do posto $\boldsymbol{Y}$ a ser estimada, $\boldsymbol{x}_{\mathbf{1}}, \boldsymbol{x}_{\mathbf{2}}$ e $\boldsymbol{x}_{\mathbf{3}}$ são as precipitações correspondentes ao mês ou ano que se deseja preencher (obtidas nas três estações vizinhas), $\boldsymbol{y}_{\boldsymbol{m}}$ é a precipitação média do posto e $\boldsymbol{x}_{\boldsymbol{m} \mathbf{1}}, \boldsymbol{x}_{\boldsymbol{m} \mathbf{2}}$ e $\boldsymbol{x}_{\boldsymbol{m} \mathbf{3}}$ são as precipitações médias nas três estações vizinhas.

Deve-se observar que todos os postos utilizados nesse processo devem possuir as mesmas condicionantes geológicas, e que por ser um método simples, apresenta limitações, não sendo aconselhável o uso para o preenchimento de falhas em valores diários de precipitação. De acordo com Bertoni e Tucci (2007) estes valores são de difícil preenchimento devido a grande variação espacial e temporal da precipitação para os eventos de frequências médias e pequenas.

Após o preenchimento das falhas encontradas nas séries selecionadas para esta pesquisa, foi realizada a analise de consistência dos dados a fim de se verificar o grau de homogeneidade dos dados de cada série em relação aos valores observados nos postos vizinhos.

Foi aplicado o Método da Dupla Massa, desenvolvido pelo U.S. Geological Survey (USGS) (SEARCY E HARDISON, 1960), que consiste em 
acumular os valores mensais ou anuais da série e plotar num gráfico cartesiano os valores do posto a ser verificado nas ordenadas e de outro posto confiável (ou de um conjunto de postos) nas abscissas. Se os valores do posto que se deseja verificar forem proporcionais aos demais postos de comparação (ou a média deles), os pontos irão se alinhar em uma única reta.

Segundo Bertoni e Tucci (2007), o alinhamento dos pontos no gráfico pode apresentar outros padrões, que estão relacionados a diferentes problemas (Figura 19):

I - Mudança de declividade: indica a presença de erros sistemáticos relacionados com alterações das condições de observação ou a existência de uma causa física;

II - Alinhamento dos pontos em retas paralelas: ocasionado por erros de transcrição de um ou mais dados ou pela presença de anos extremos em uma das séries;

III - Distribuição errática dos pontos: decorrente da comparação de postos com diferentes regimes pluviométricos.

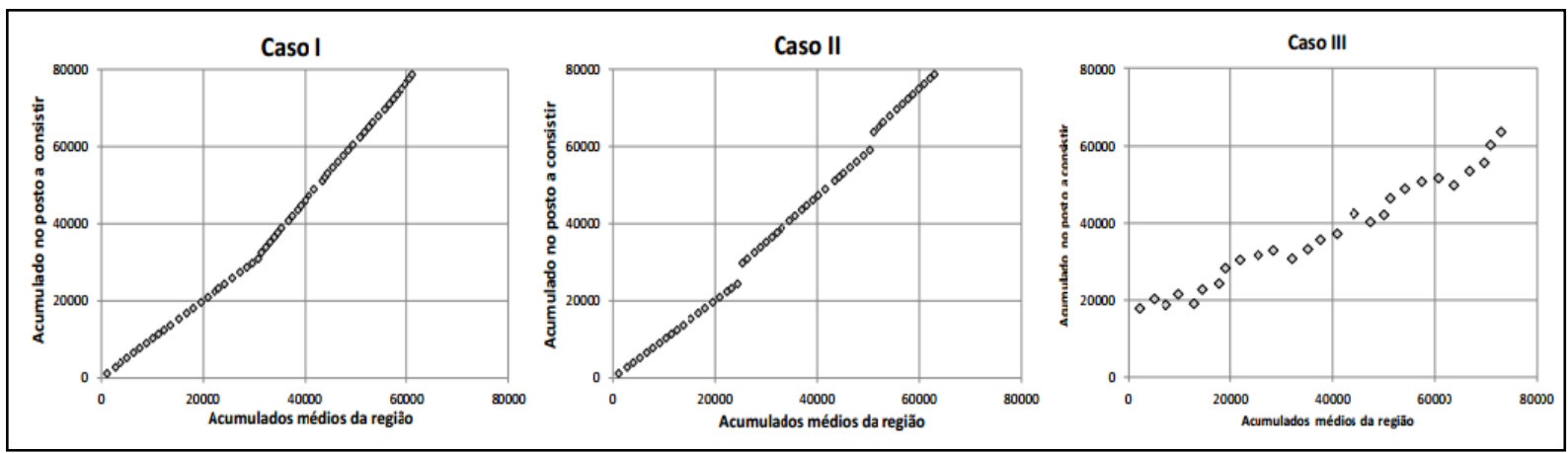

Figura 19: Método da Dupla Massa - Inconsistências

Fonte: Bertoni e Tucci (2007)

Deve-se ter o cuidado de utilizar este método somente com valores mensais e anuais. 
Com as séries de dados devidamente corrigidas, passou-se para fase de análise dos dados, objetivando detectar a existência e magnitude de tendências significativas. Conti (1995, p.97) define tendência “(...$)$ como a função valor médio de seu processo gerador, poderá ser crescente, decrescente ou estacionária. Expressa-se pela reta dos mínimos quadrados".

Foram realizados cálculos dos totais anuais e trimestrais de precipitação a partir dos valores mensais de todas as séries e o cálculo da frequência diária de chuvas a partir de $20 \mathrm{~mm}$ dos dados das três Estações Meteorológicas.

Os valores das séries selecionados foram transformados em gráficos e ajustadas às retas de tendência, expressas pela equação $\mathbf{y}=\mathbf{b} \cdot \mathbf{x}+\mathbf{a}$, onde $\mathbf{a}$ representa o coeficiente linear da reta e b o coeficiente angular, através da técnica de regressão linear.

Também foram traçadas nos gráficos as médias móveis simples de grau 2, em escala de tempo trimestral, com o objetivo de eliminar ruídos ou ressaltar variações de curto prazo que as retas de tendência ocultam.

Por fim foram calculados os coeficientes de determinação $\left(\mathbf{R}^{\mathbf{2}}\right)$ para verificar se as taxas de variação anuais e trimestrais eram nulas ou não, e analisar se os valores das alturas pluviométricas crescem ou decrescem com a variação temporal.

\subsection{Análise das séries de totais pluviométricos anuais e sazonais}

Para as análises do comportamento das chuvas anuais e sazonais foram utilizadas os dados das dez séries temporais selecionadas, com períodos variando de 30 (Guarulhos) a 80 (IAG) anos de registros. 
Os valores anuais de alturas pluviométricas apontaram que sete (Gráficos 01, 02, 03, 04, 05, 06 e 07) das dez séries analisadas possuem uma tendência positiva de aumento da precipitação. Os valores mais significativos foram registrados nas estações do IAG e Mirante de Santana, e no posto pluviométrico Fazenda São Bento (Gráficos 01, 03 e 05).

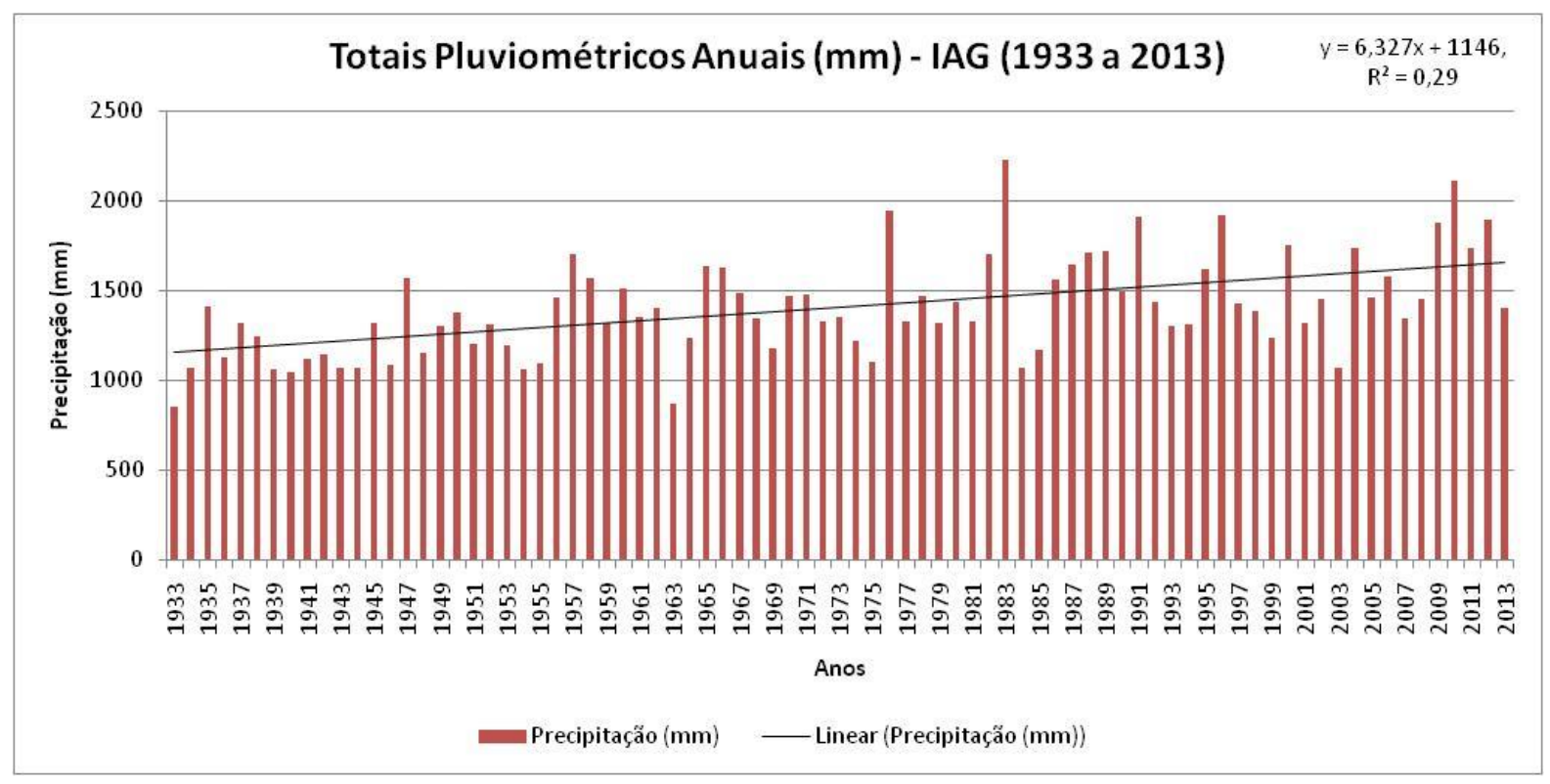

Gráfico 01: Valores anuais de alturas pluviométricas - IAG

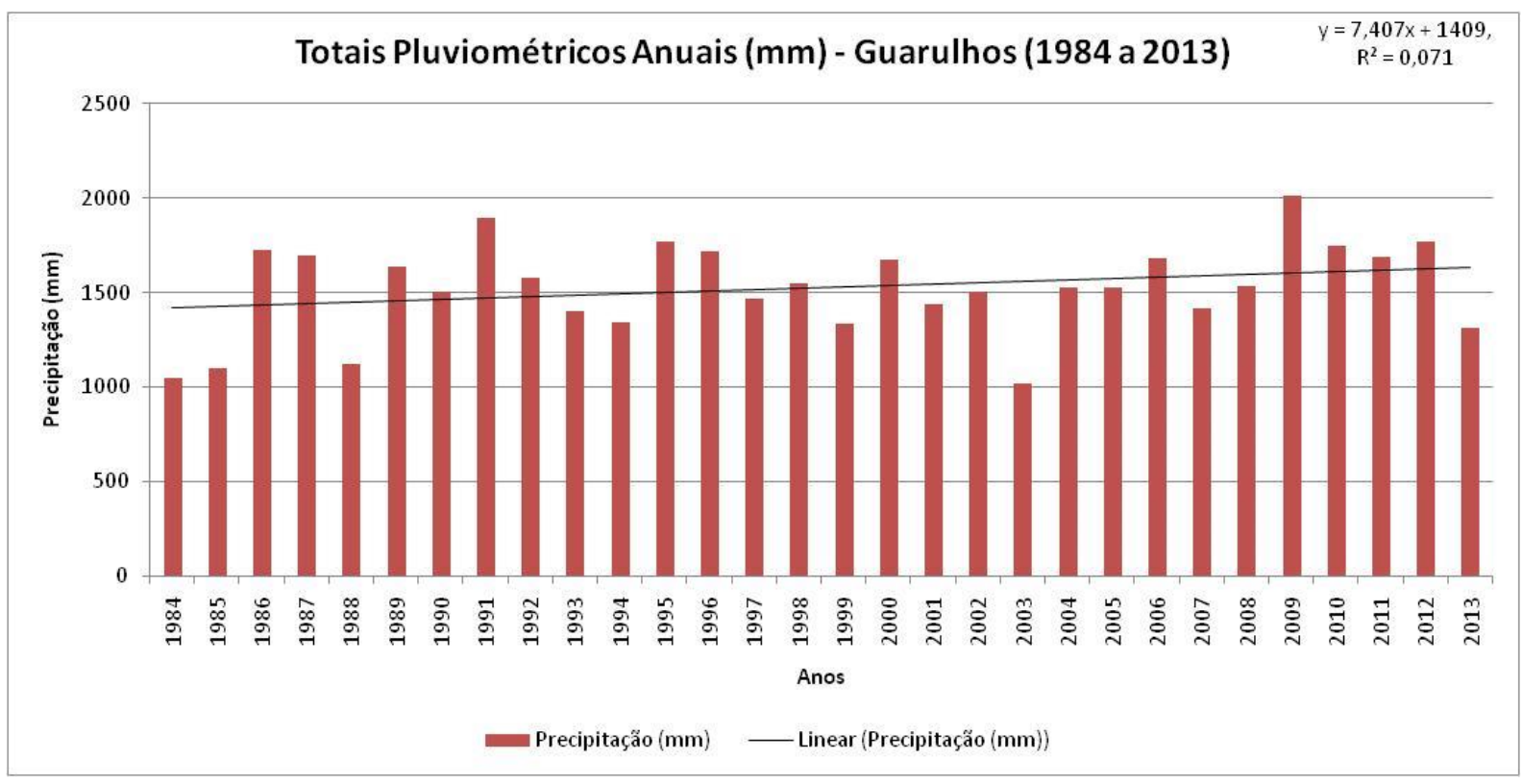

Gráfico 02: Valores anuais de alturas pluviométricas - Guarulhos 


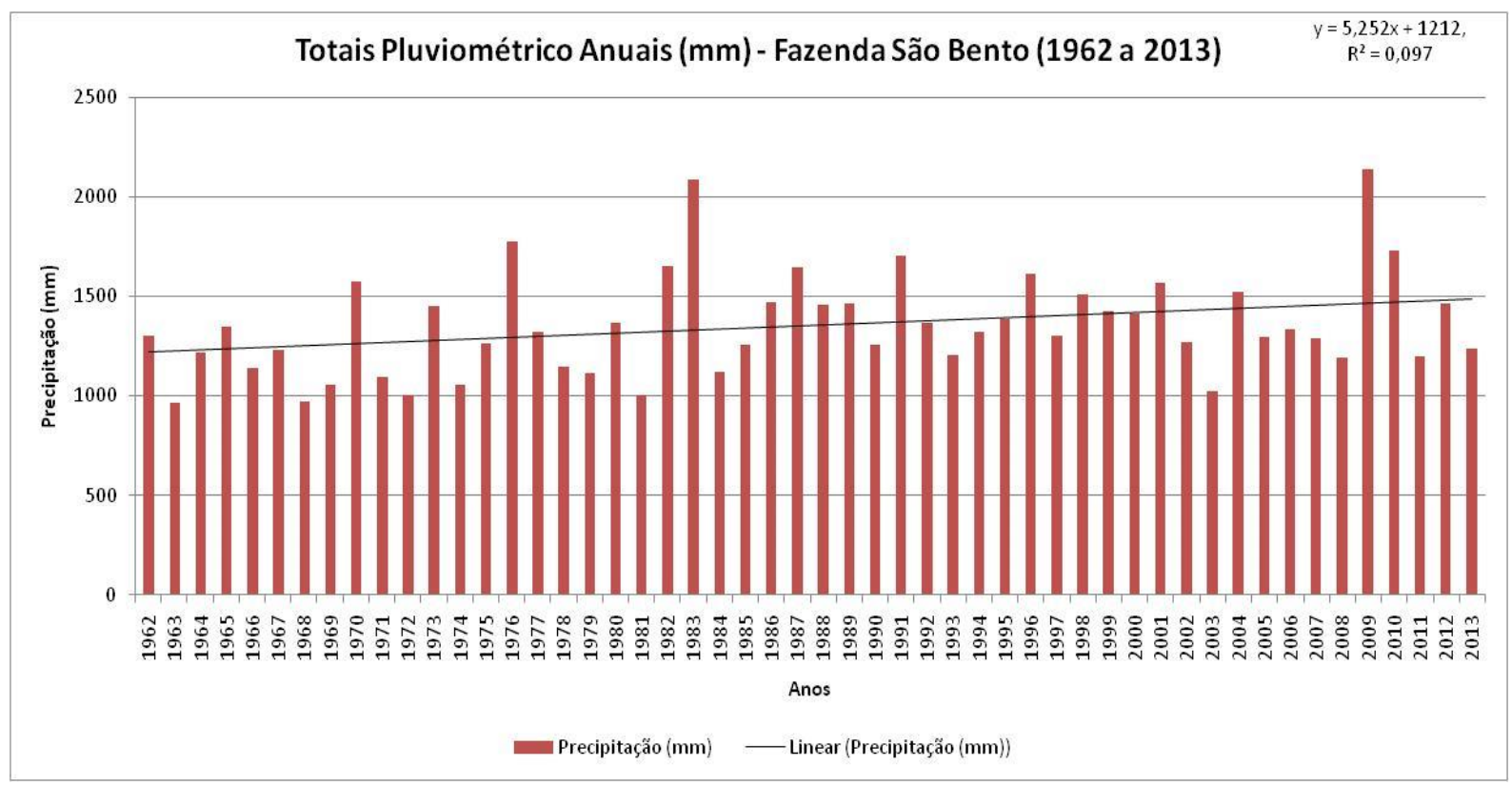

Gráfico 03: Valores anuais de alturas pluviométricas - Fazenda São Bento

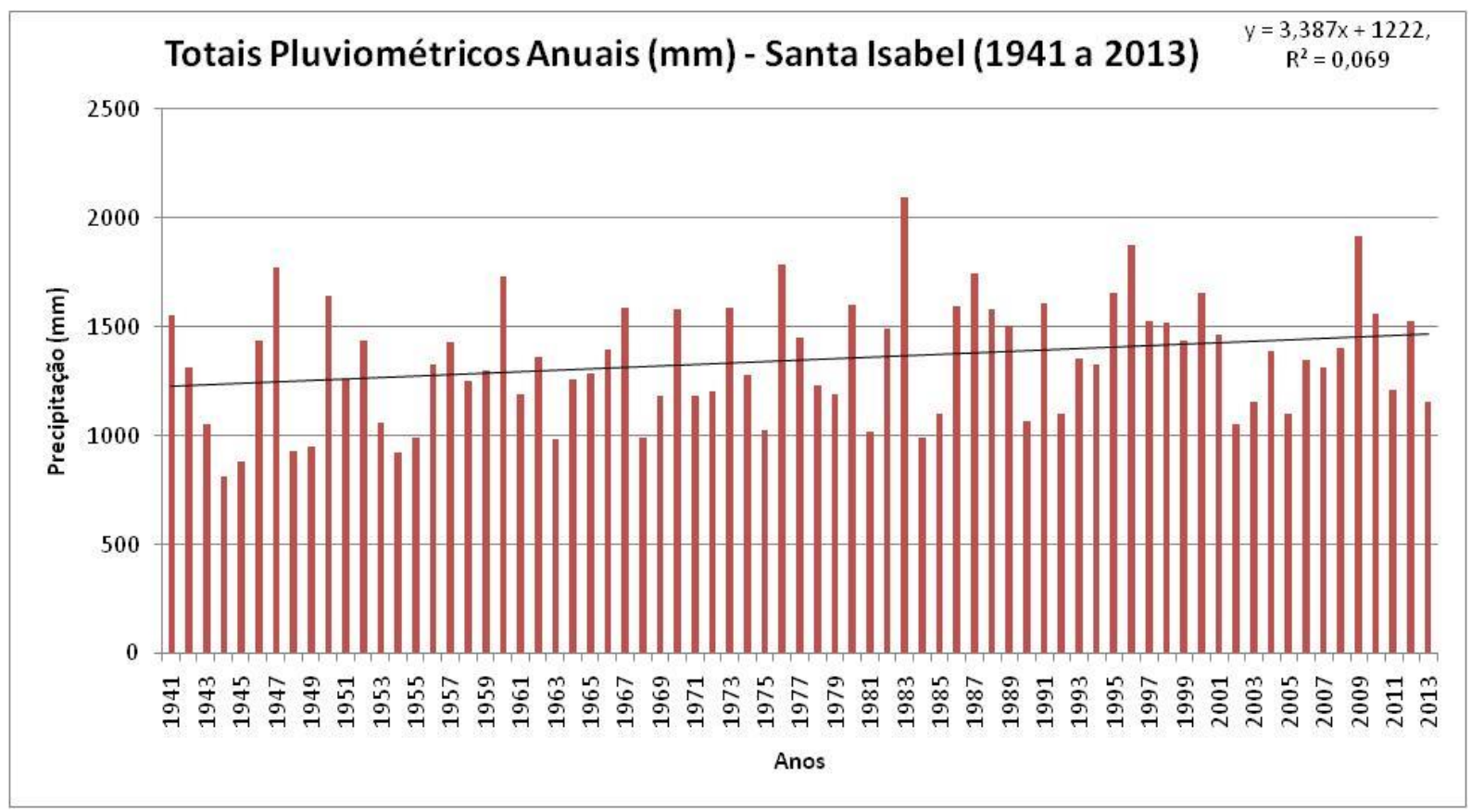

Gráfico 04: Valores anuais de alturas pluviométricas - Santa Isabel 


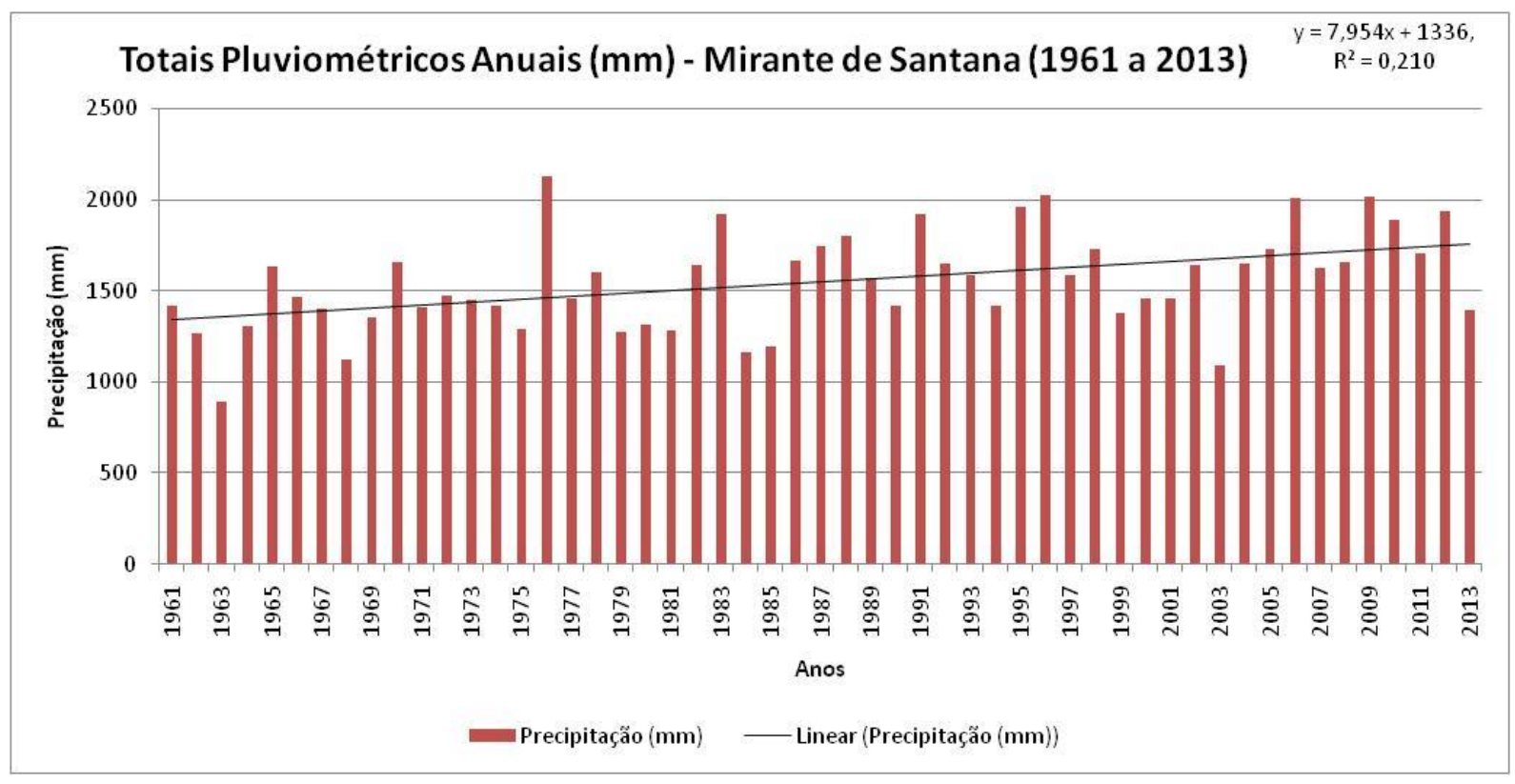

Gráfico 05: Valores anuais de alturas pluviométricas - Mirante de Santana

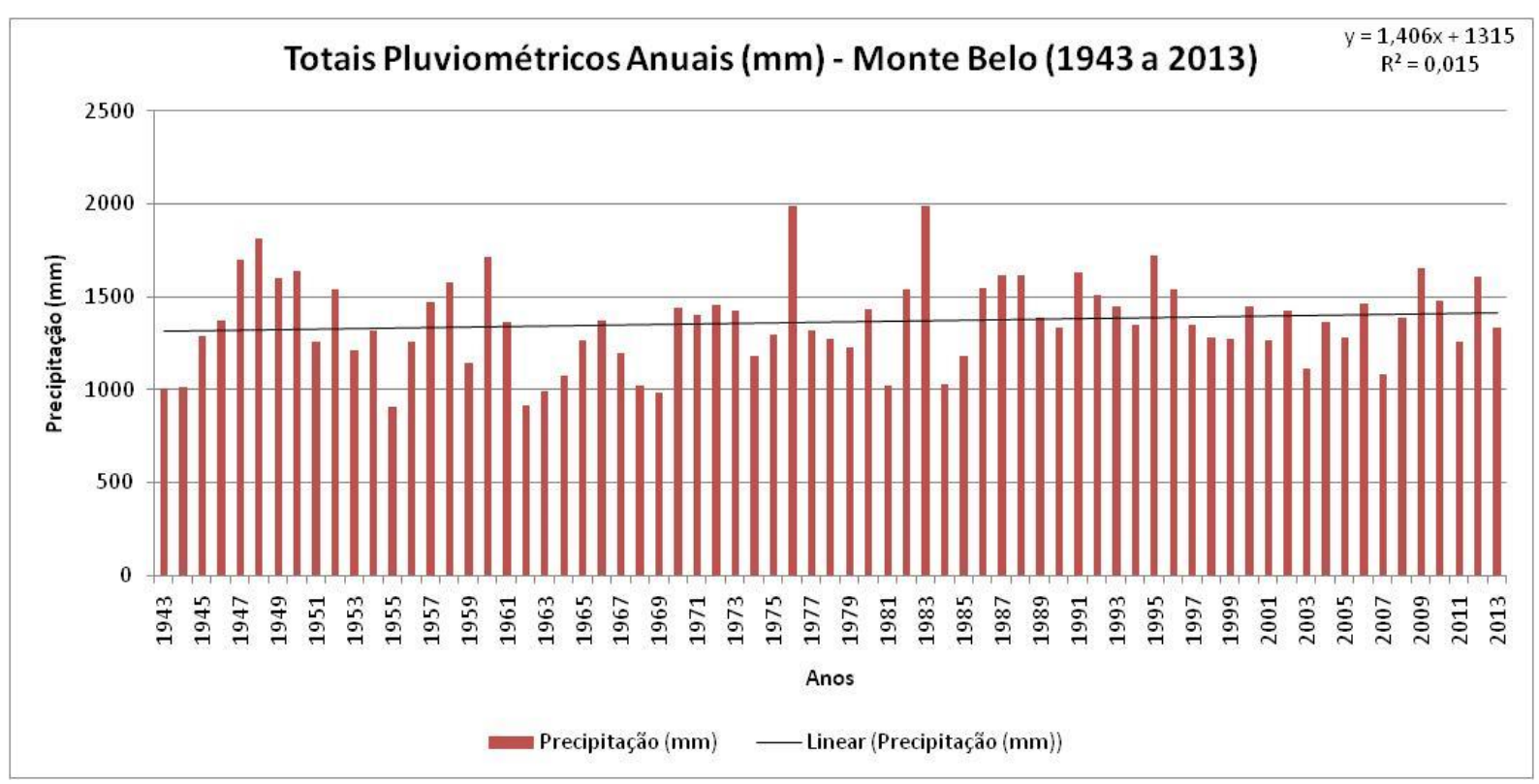

Gráfico 06: Valores anuais de alturas pluviométricas - Monte Belo 


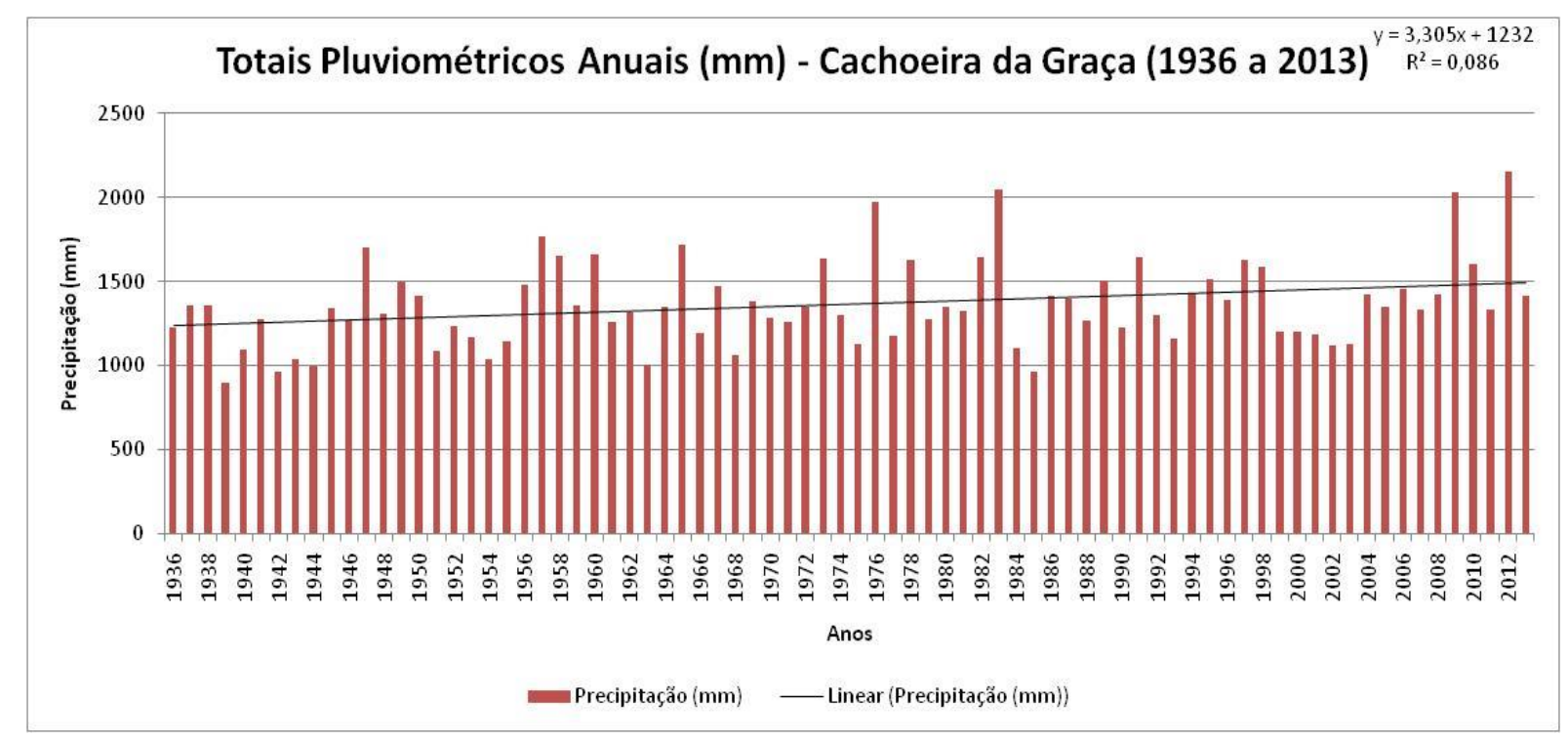

Gráfico 07: Valores anuais de alturas pluviométricas - Cachoeira da Graça

É interessante notar que a maior parte das séries de dados com tendências positivas de aumento de precipitação se encontra em áreas densamente urbanizadas da RMSP, e mesmo quando o ponto de coleta da estação se localiza em uma área verde, como é o caso da estação meteorológica do IAG, é possível perceber que o entorno próximo se caracteriza como área urbana (Figura 18).

As séries de dados referentes aos postos pluviométricos Juquitiba e Baixo Cotia apresentaram tendências nulas de aumento de precipitação anual (Gráficos 08 e 09), o que significa que ao longo dos anos de registro os totais de chuva anuais se mantiveram dentro das expectativas para os três postos. 


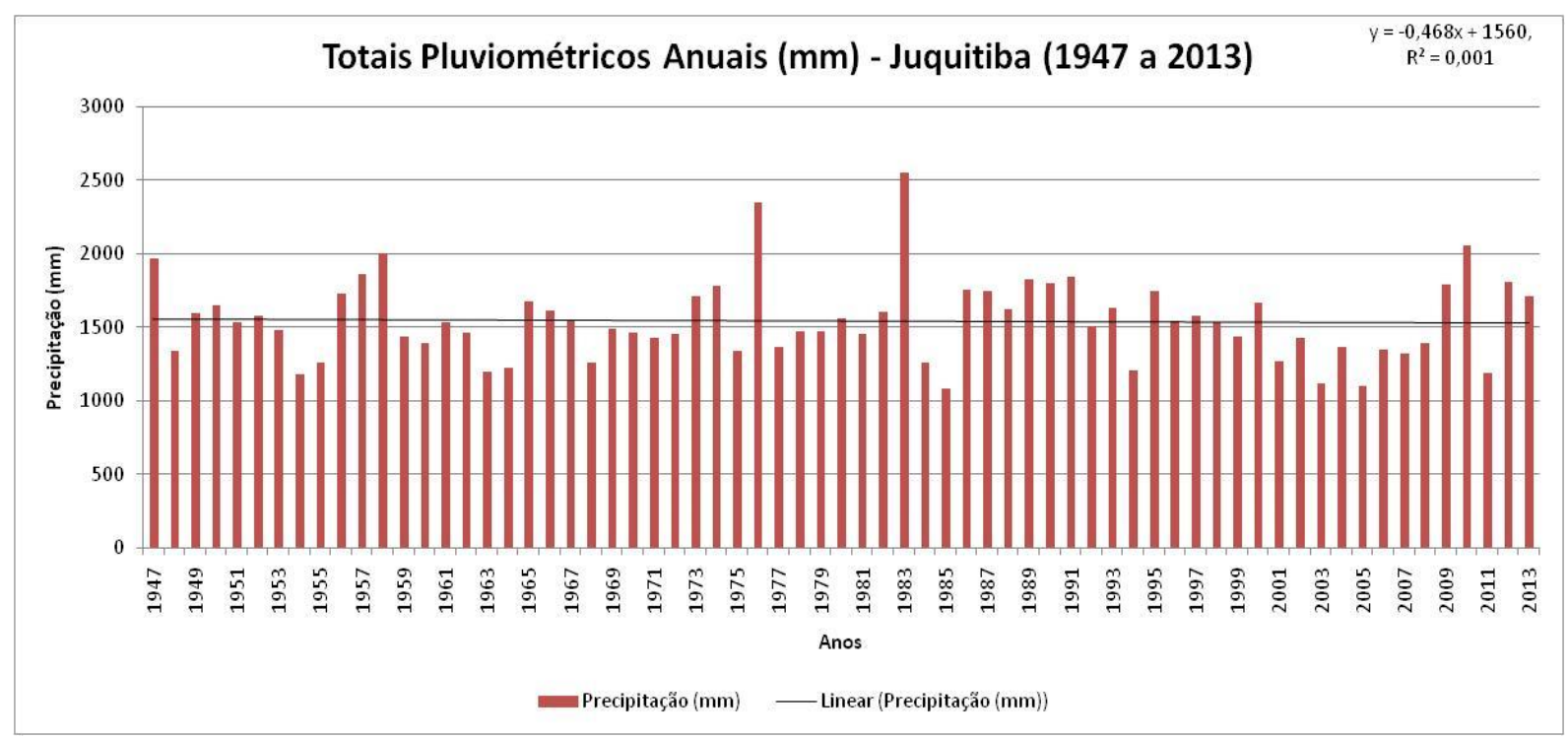

Gráfico 08: Valores anuais de alturas pluviométricas - Juquitiba

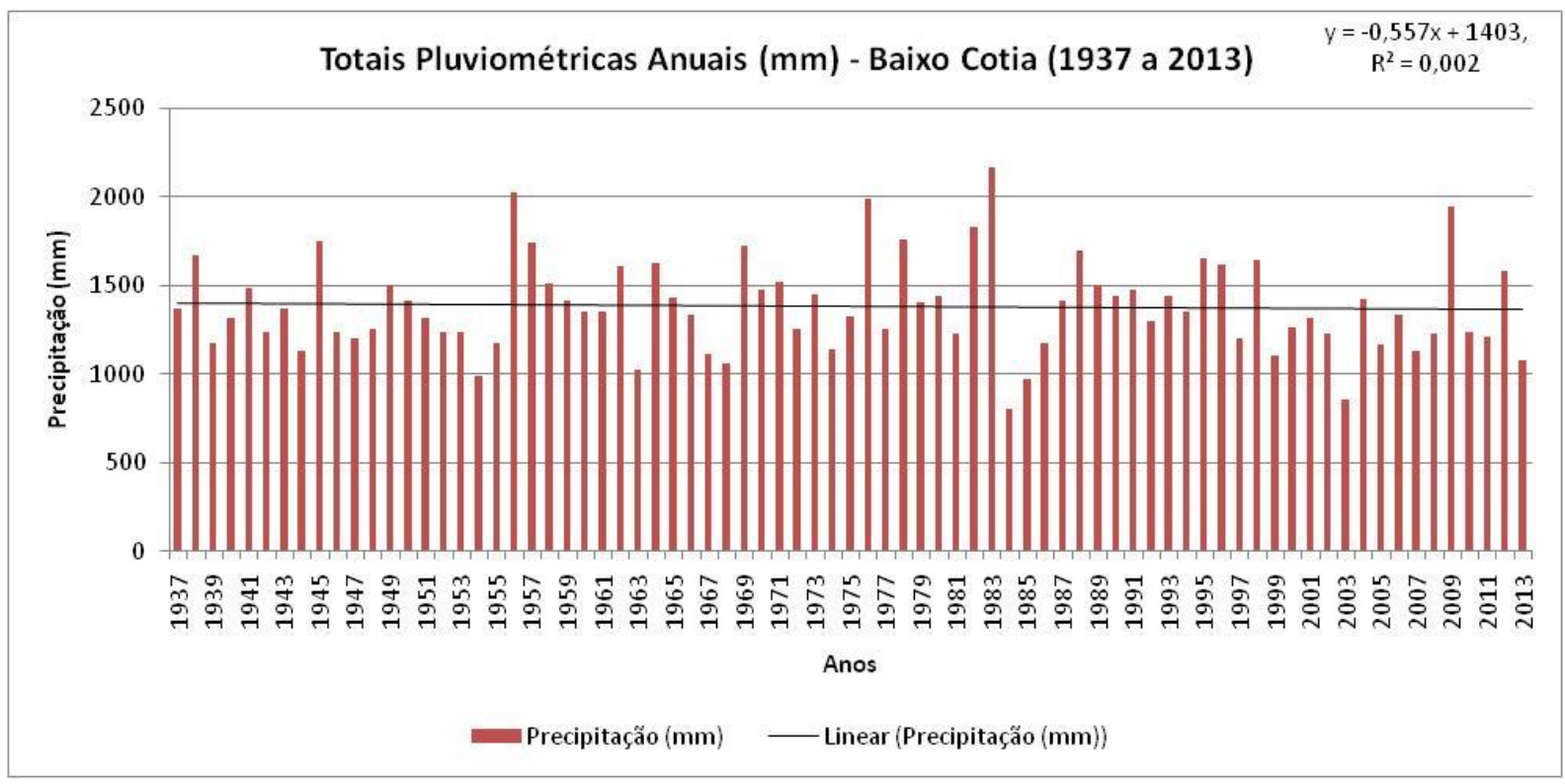

Gráfico 09: Valores anuais de alturas pluviométricas - Baixo Cotia

De todas as séries analisadas, apenas uma (Ponte Nova) apresentou tendência negativa de aumento de precipitação anual (Gráfico 10). 


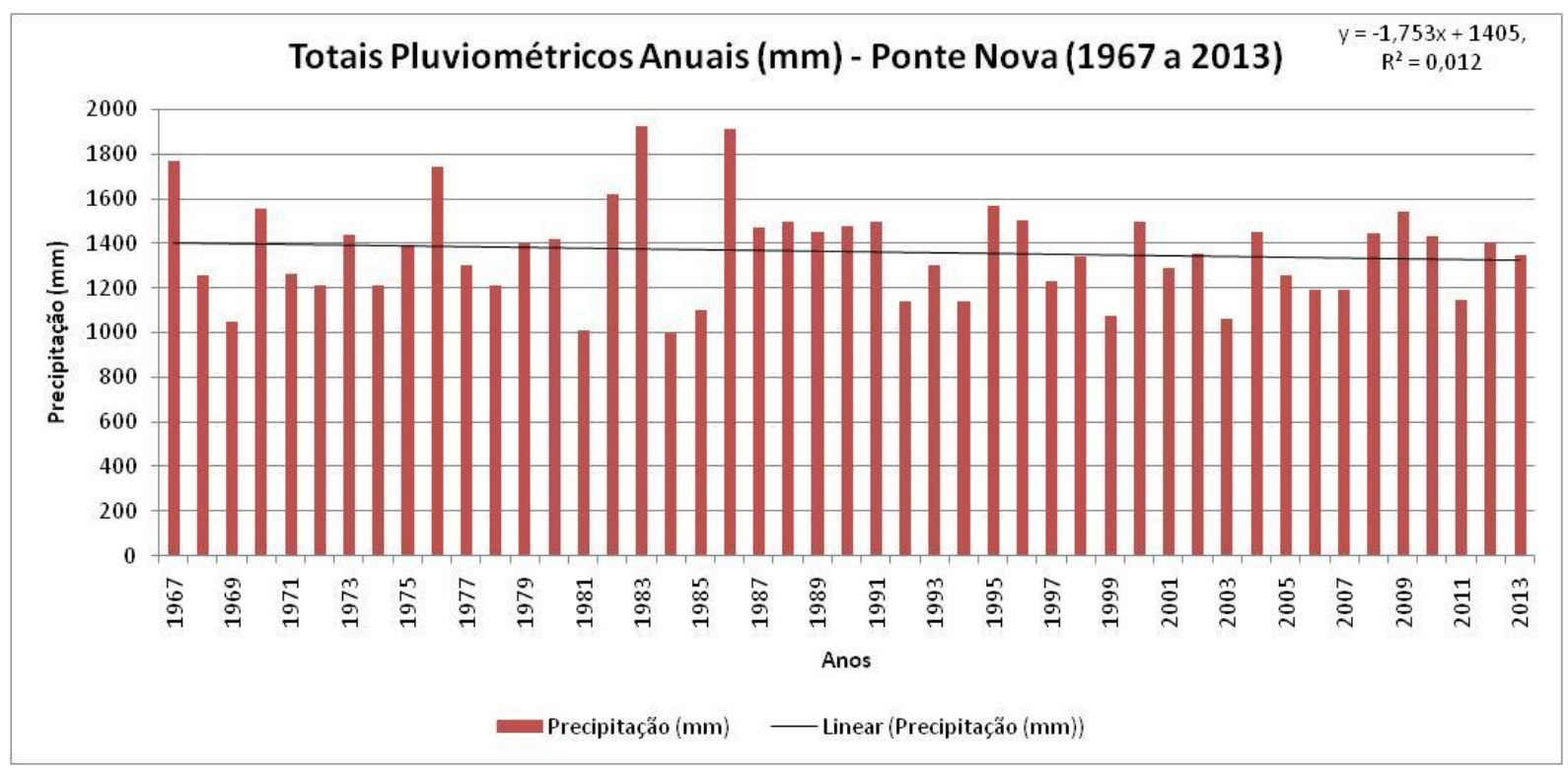

Gráfico 10: Valores anuais de alturas pluviométricas - Ponte Nova

Em relação aos valores de verão (janeiro a março), que se caracteriza como o período mais chuvoso na RMSP, foi possível notar que seis, das dez séries de dados analisadas, apresentaram tendências positivas de aumento de precipitação (Gráficos 11, 12, 13, 14, 15 e 16), sendo três delas bem marcadas (Cachoeira da Graça, Mirante de Santana e Fazenda São Bento).

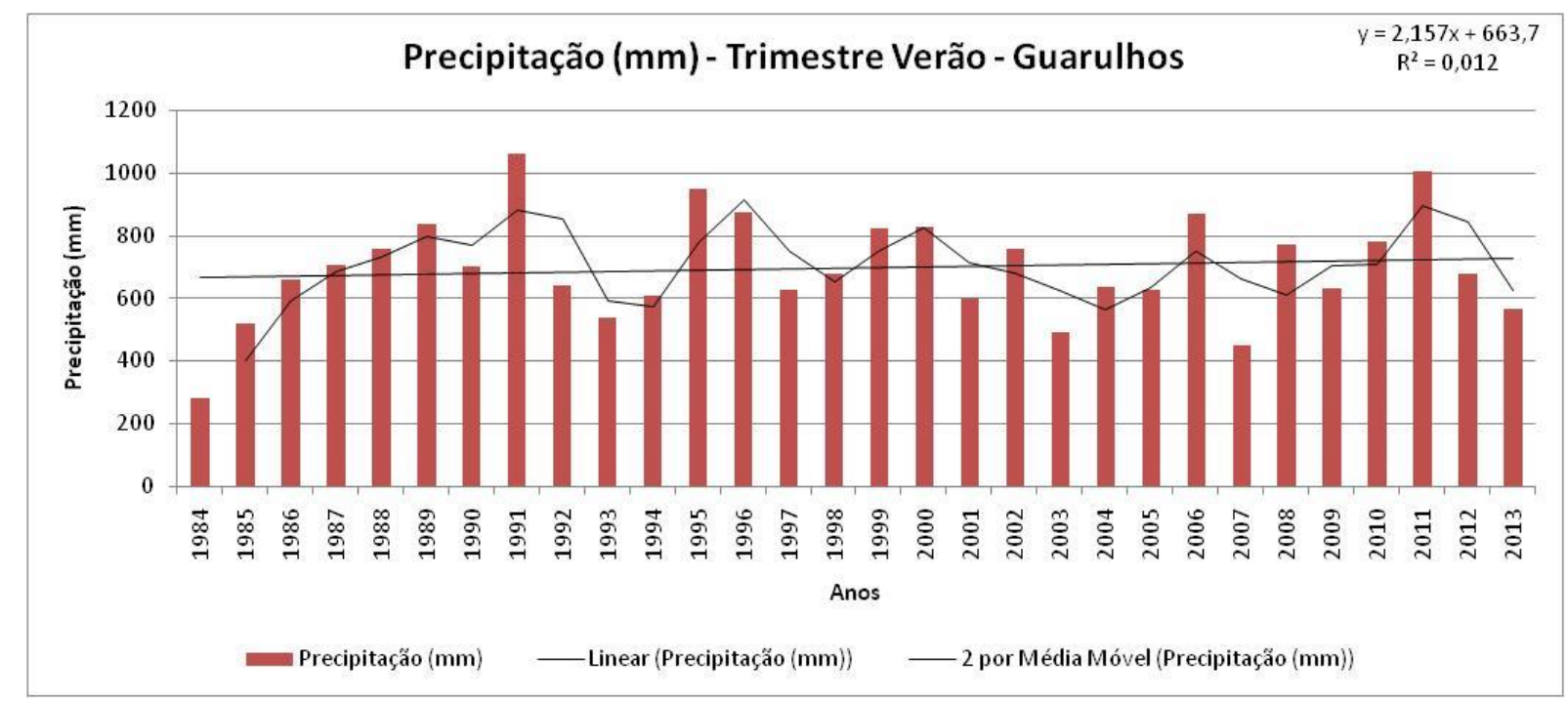

Gráfico 11: Valores trimestrais de alturas pluviométricas - Trimestre Verão - Ponte Nova 


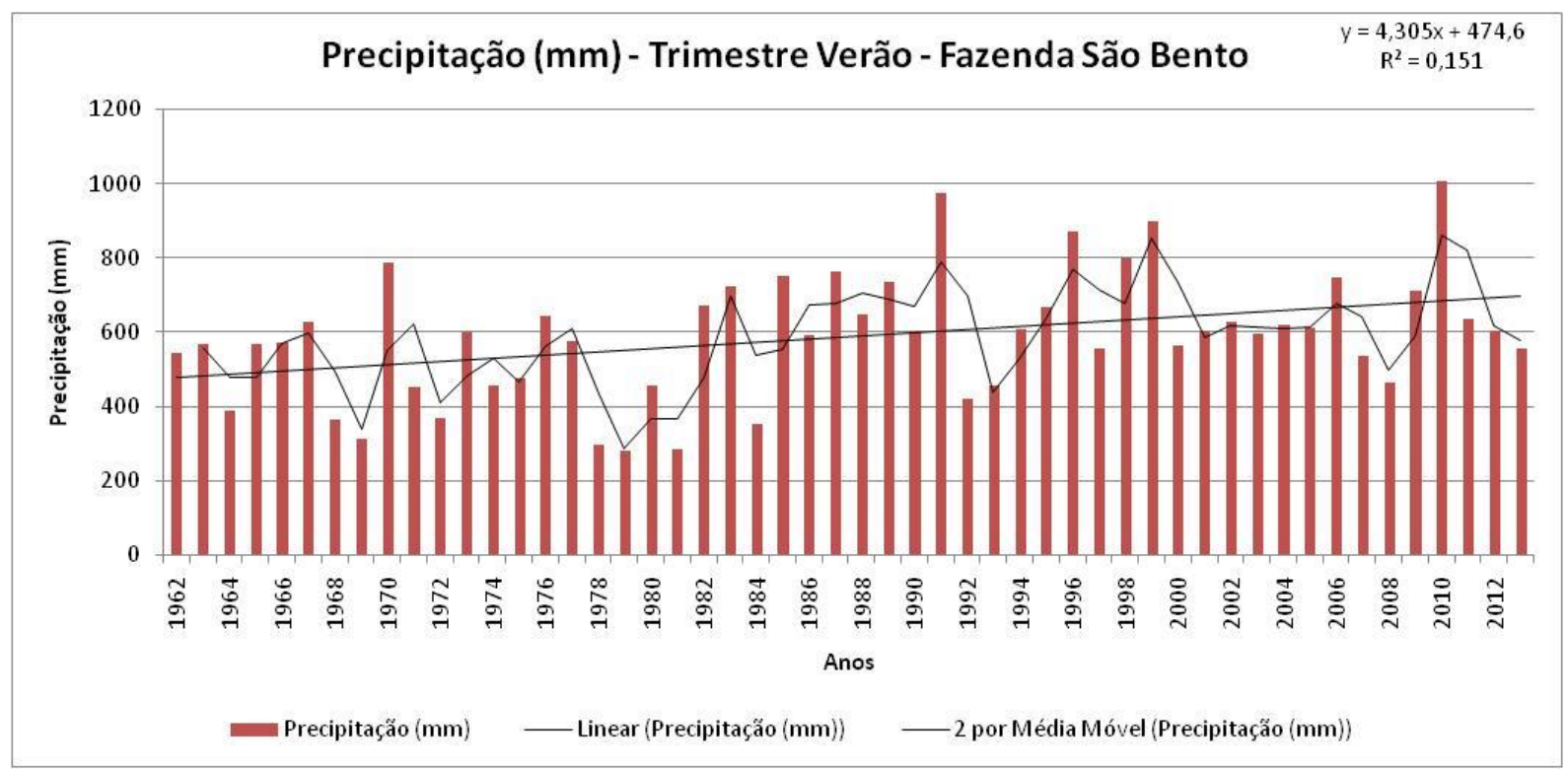

Gráfico 12: Valores trimestrais de alturas pluviométricas - Trimestre Verão - Fazenda São Bento

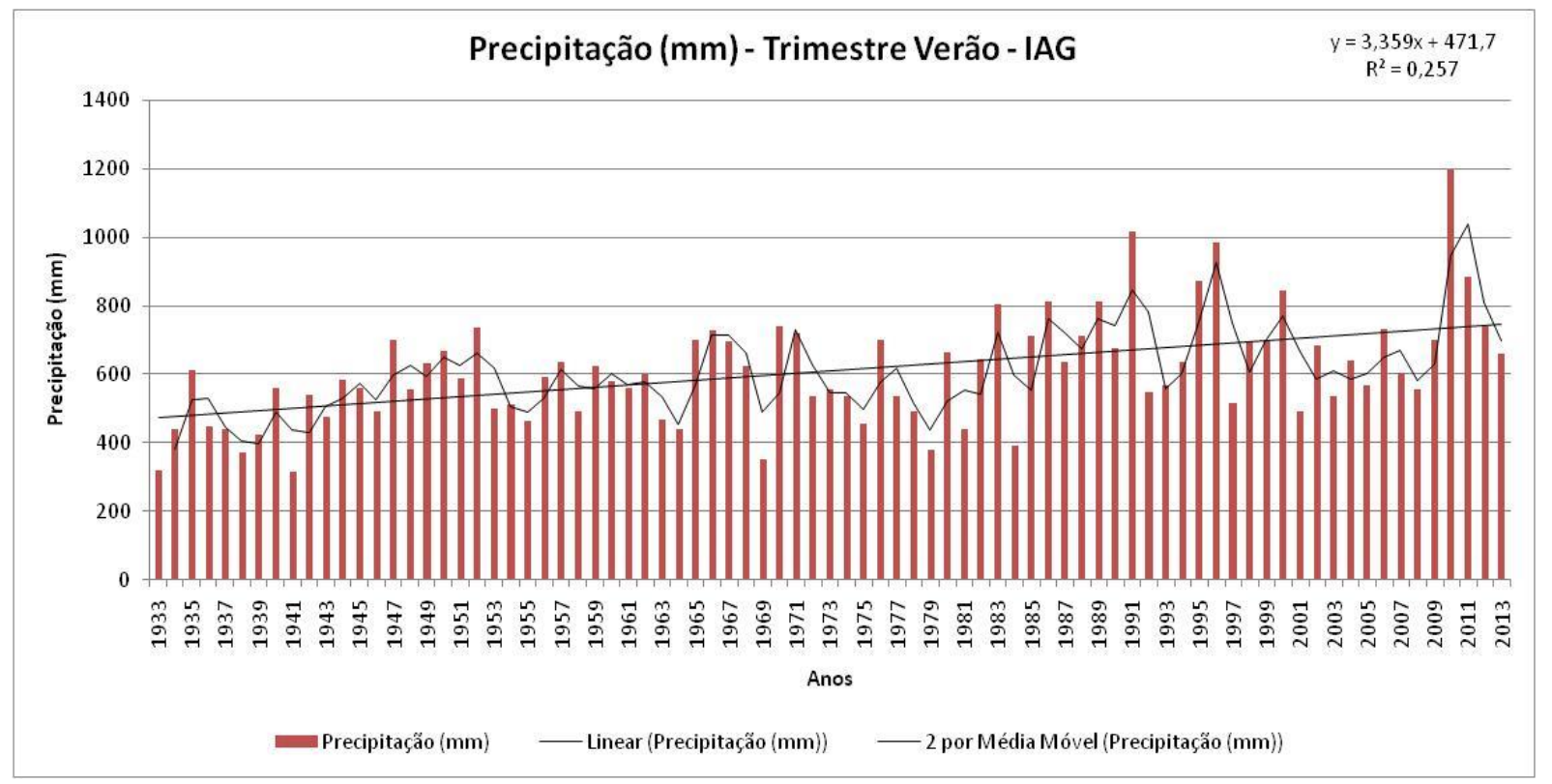

Gráfico 13: Valores trimestrais de alturas pluviométricas - Trimestre Verão - IAG 


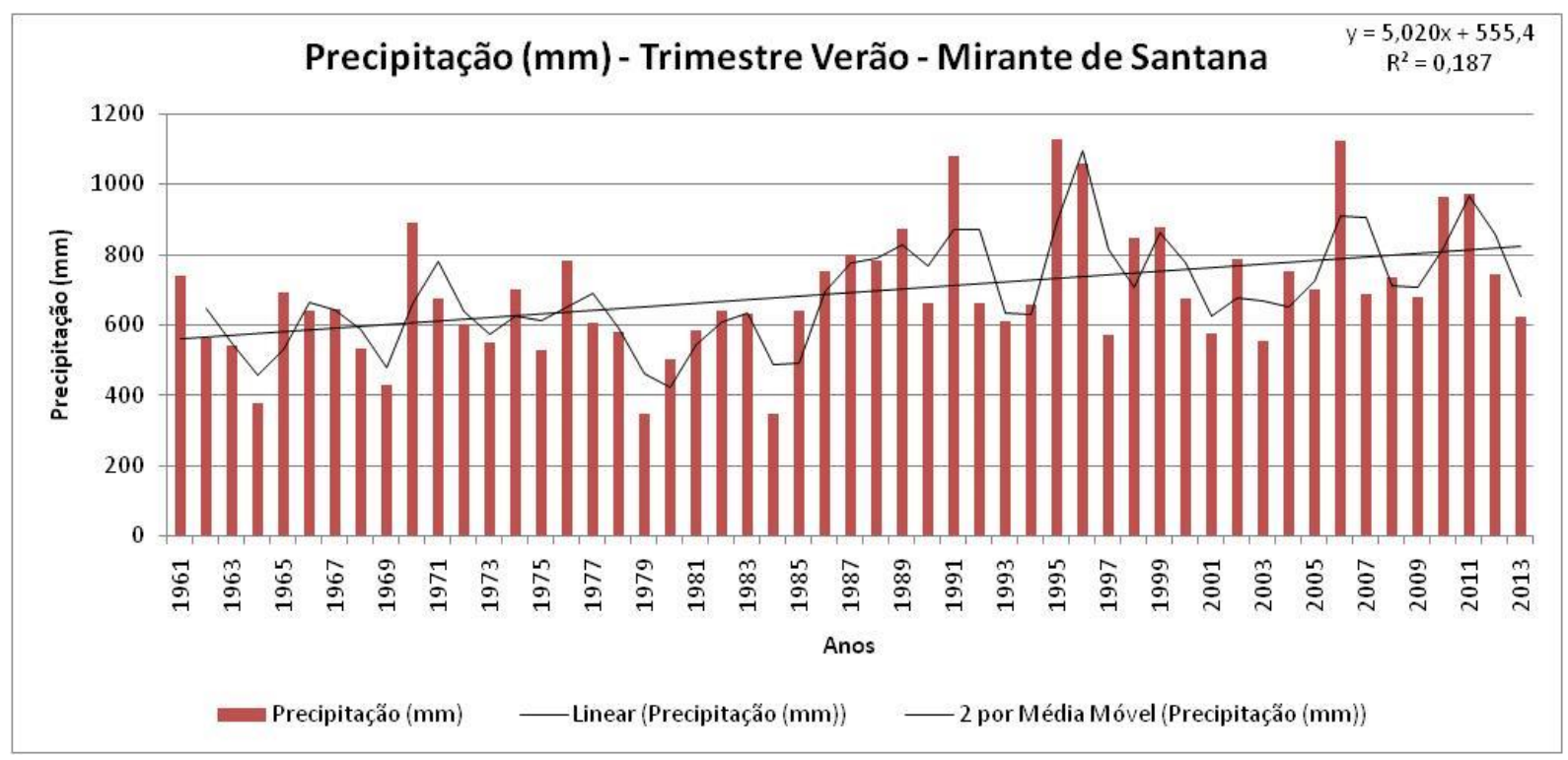

Gráfico 14: Valores trimestrais de alturas pluviométricas - Trimestre Verão - Mirante de Santana

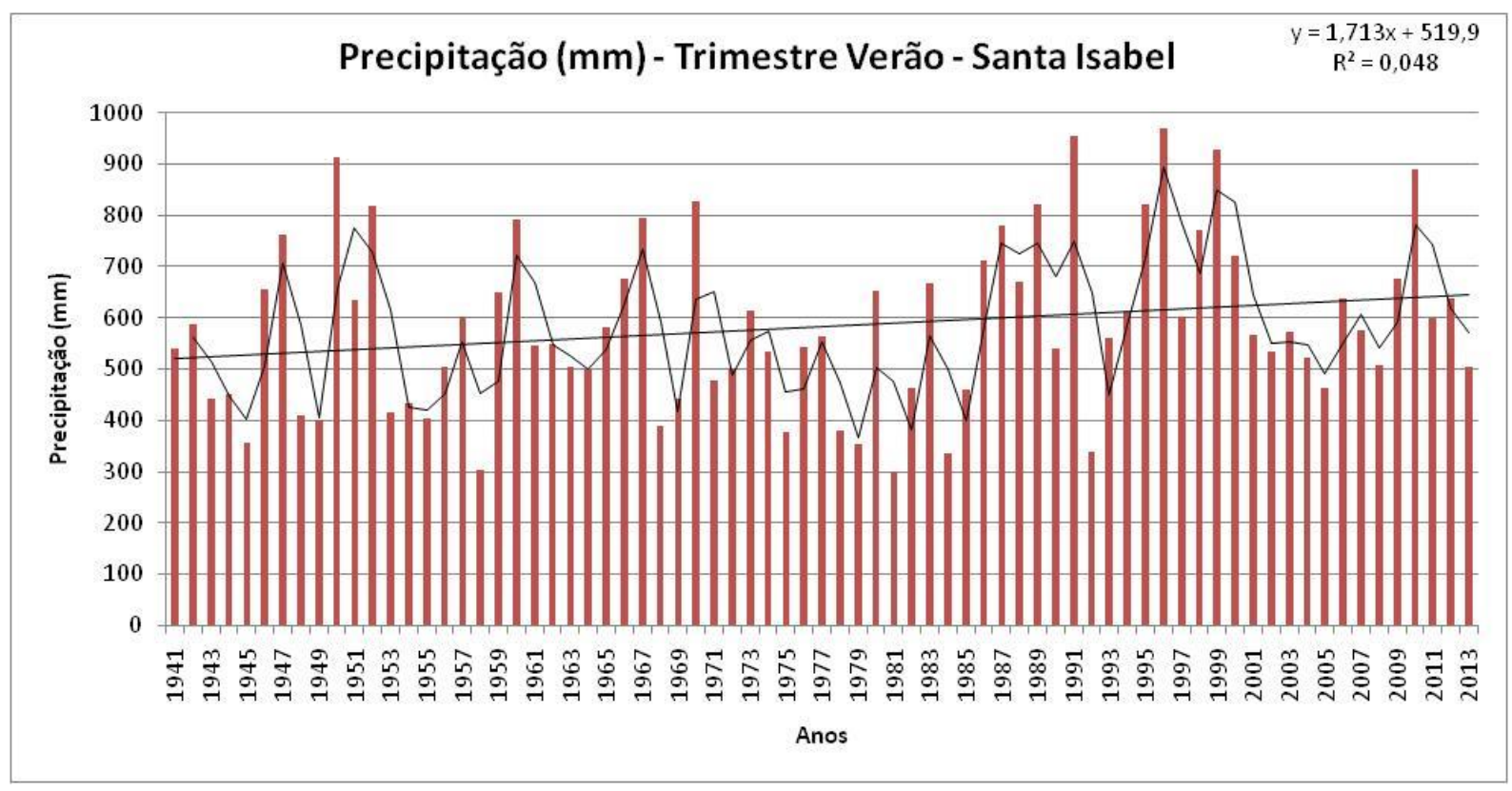

Gráfico 15: Valores trimestrais de alturas pluviométricas - Trimestre Verão - Santa Isabel 


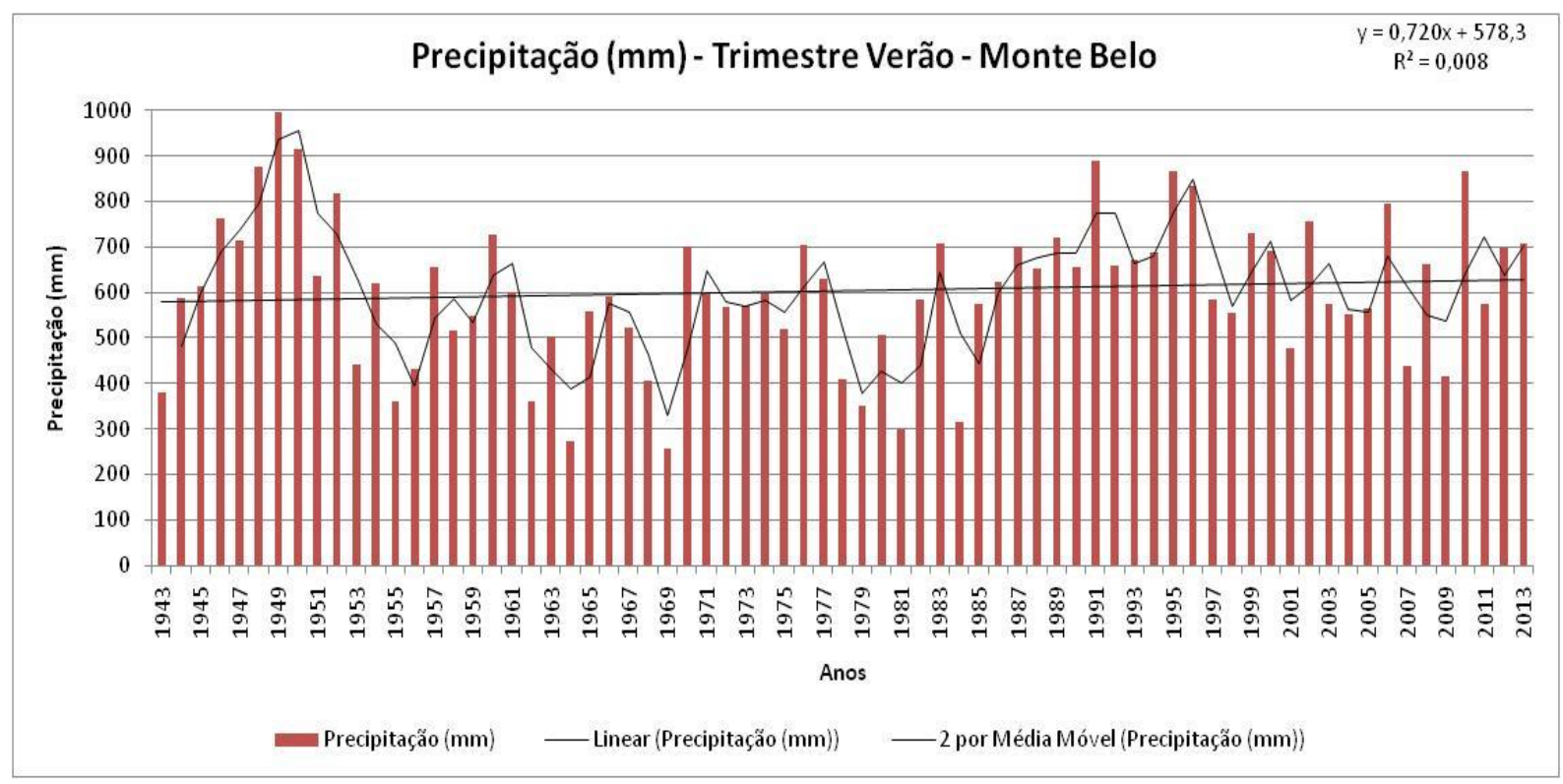

Gráfico 16: Valores trimestrais de alturas pluviométricas - Trimestre Verão - Santa Isabel

As séries de dados referentes ao trimestre de verão dos postos pluviométricos de Juquitiba e Ponte Nova (Gráficos 17 e 18) apresentaram tendência nula de aumento de precipitação, e apenas uma (Baixo Cotia) apresentou tendência negativa para esse período (Gráfico 19).

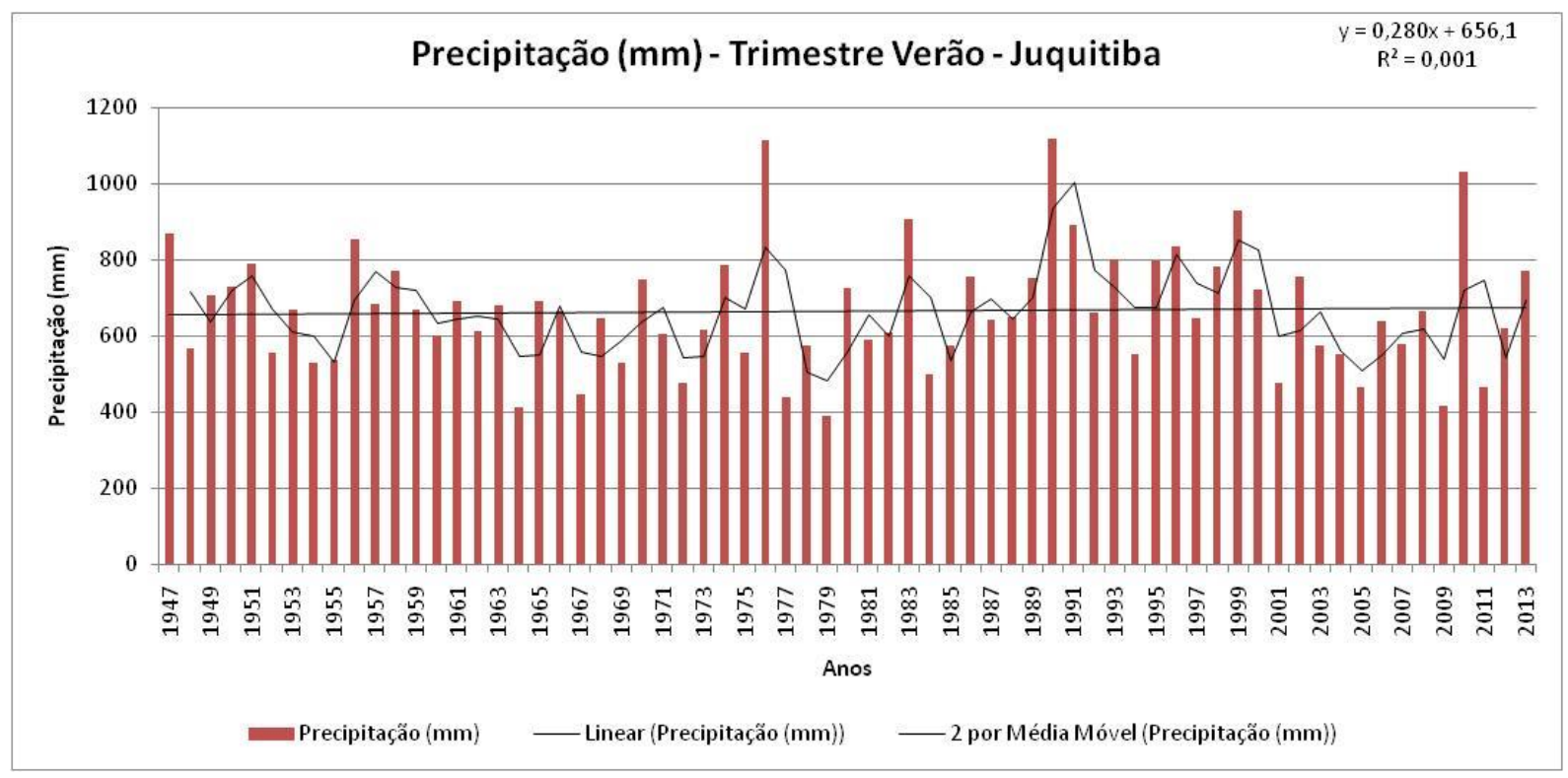

Gráfico 17: Valores trimestrais de alturas pluviométricas - Trimestre Verão - Juquitiba 


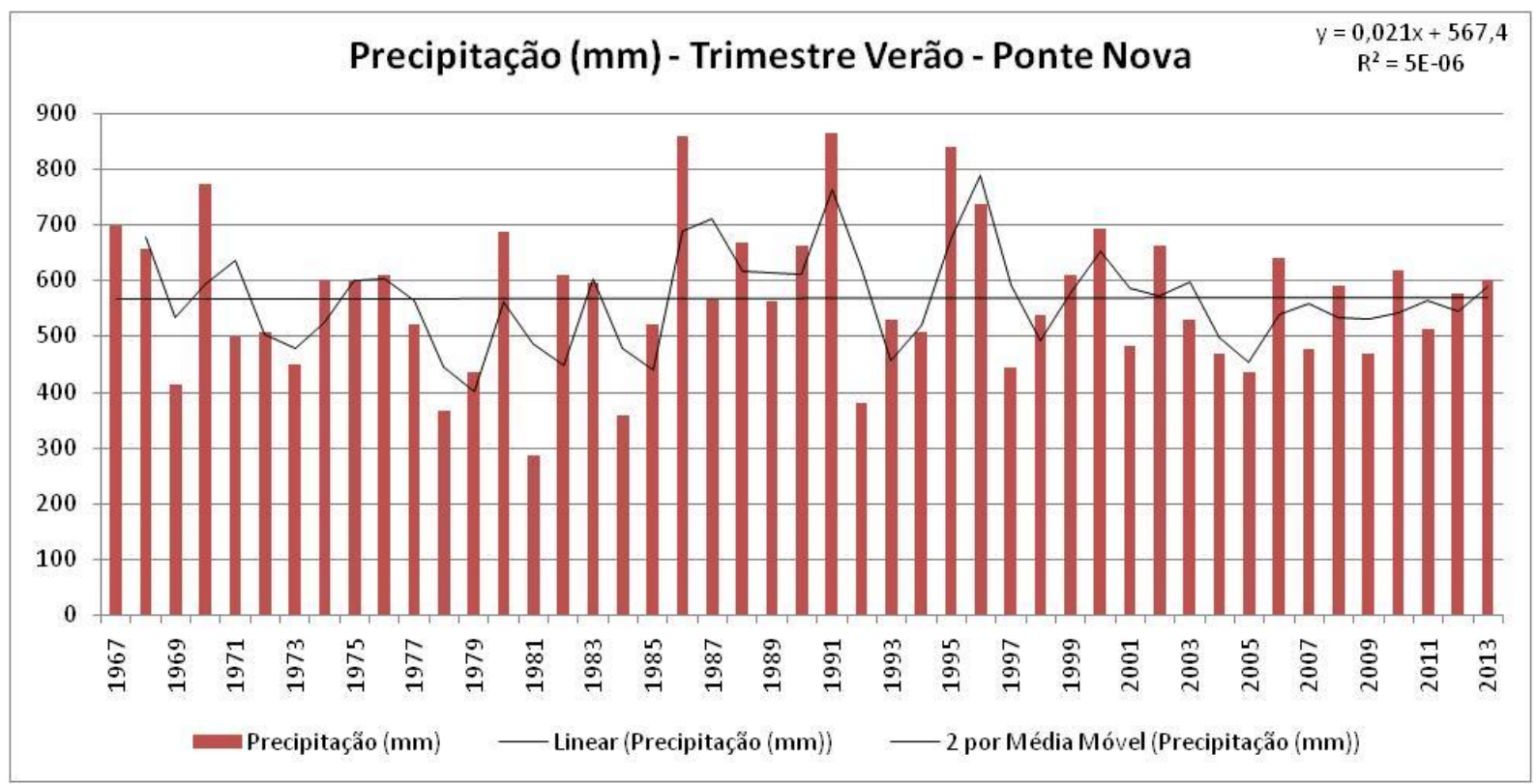

Gráfico 18: Valores trimestrais de alturas pluviométricas - Trimestre Verão - Ponte Nova

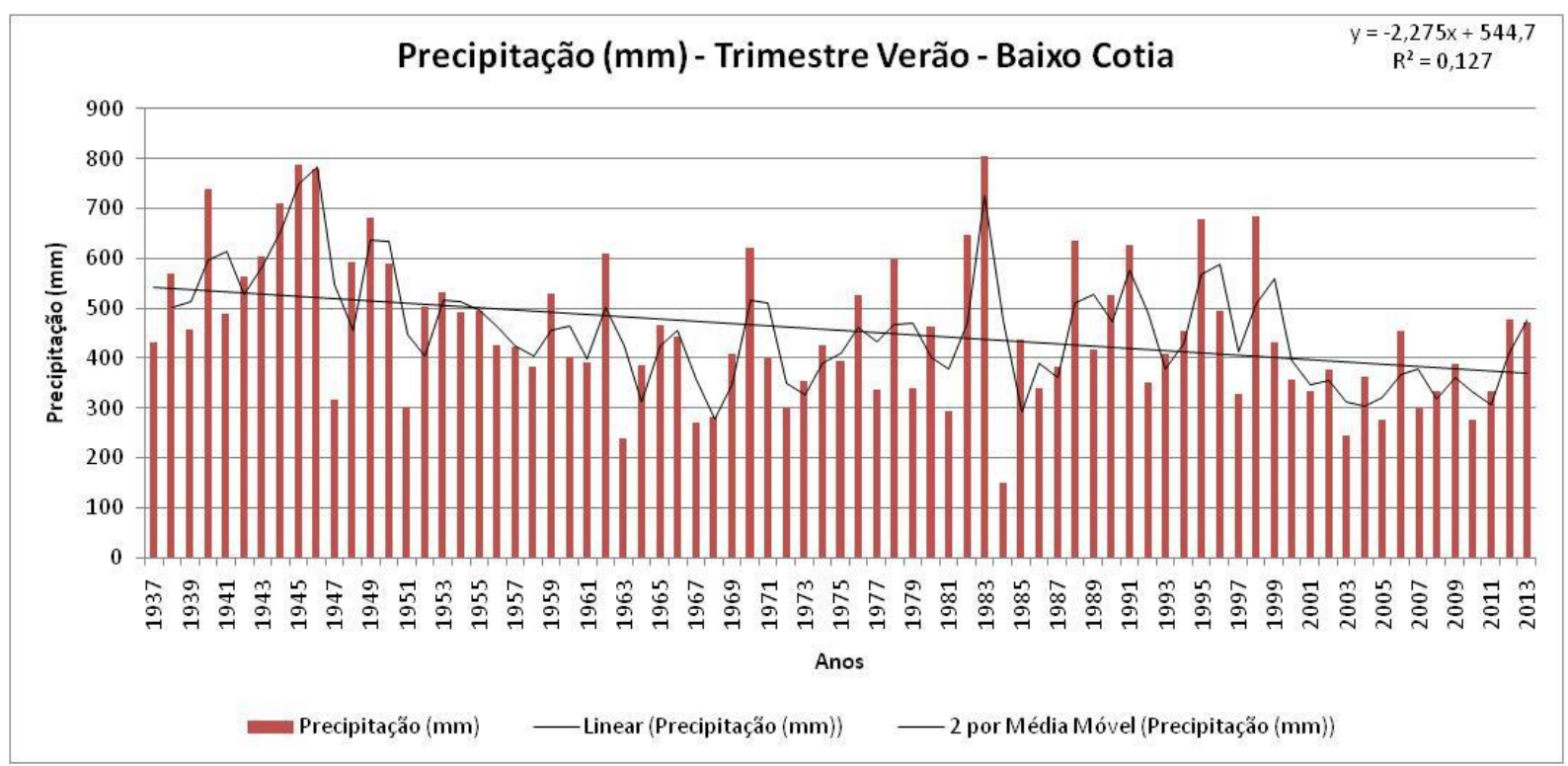

Gráfico 19: Valores trimestrais de alturas pluviométricas - Trimestre Verão - Baixo Cotia

Durante o trimestre de outono (abril a junho) é possível notar através da observação dos gráficos que os totais de precipitação diminuem consideravelmente em relação ao trimestre de verão. As séries de dados das estações meteorológicas do IAG e Mirante de Santana e dos postos 
pluviométricos Fazenda São Bento, Santa Isabel, Monte Belo e Cachoeira da Graça voltaram a apresentar tendências positivas de aumento de precipitação para esse trimestre (Gráficos 20, 21, 22, 23, 24 e 25), repetindo o padrão do período do verão.

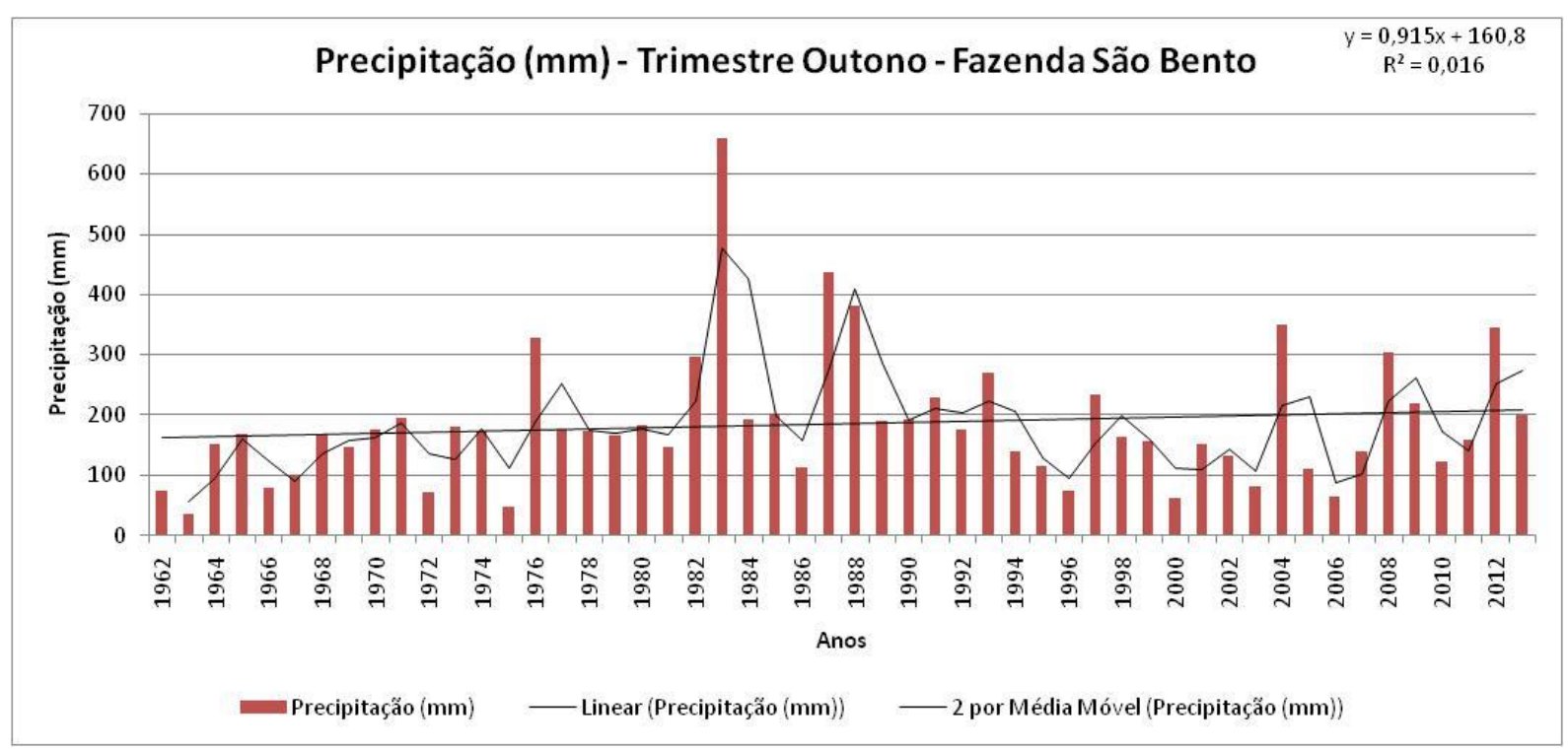

Gráfico 20: Valores trimestrais de alturas pluviométricas - Trimestre Outono - Fazenda São Bento

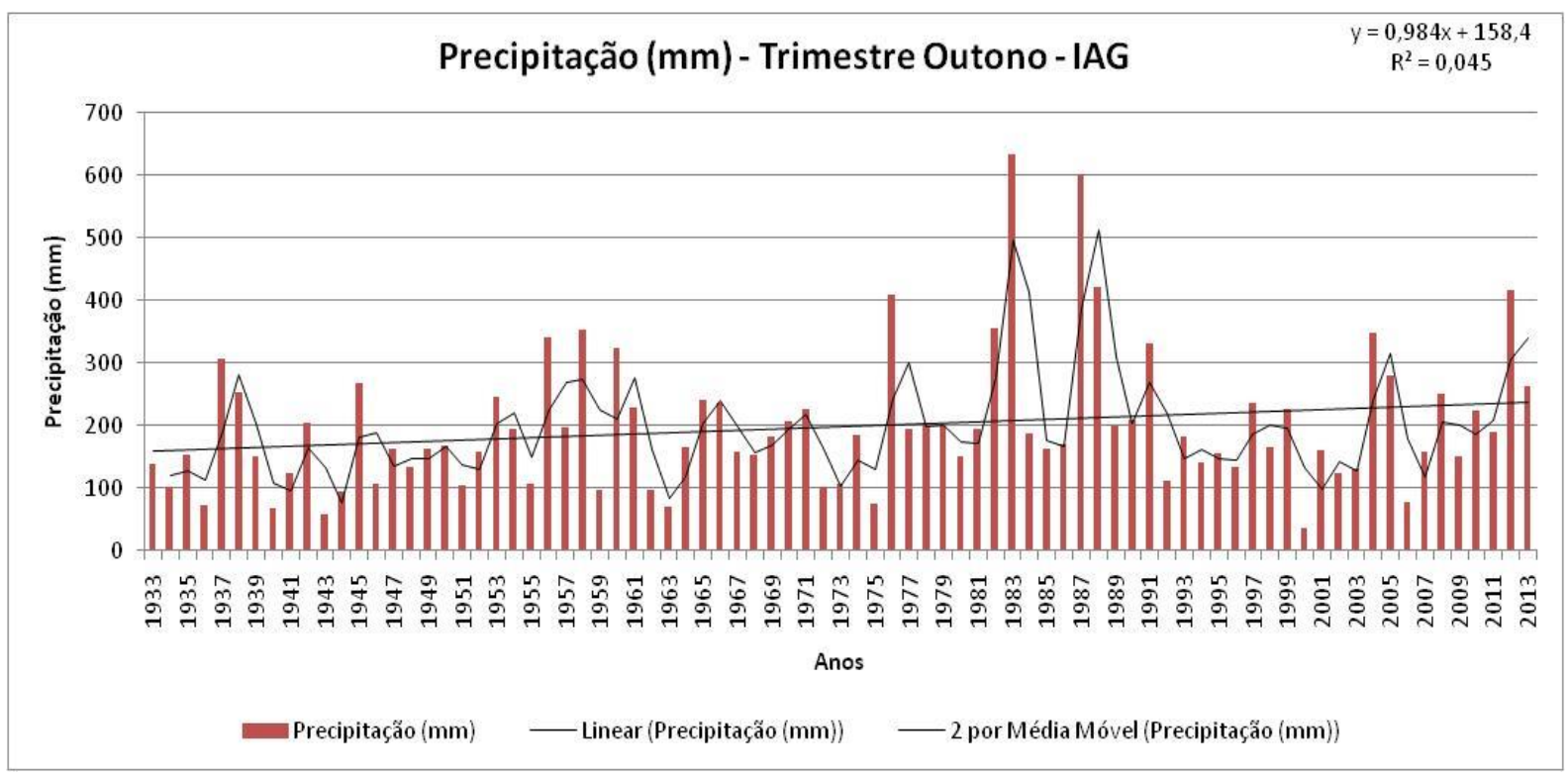

Gráfico 21: Valores trimestrais de alturas pluviométricas - Trimestre Outono - IAG 


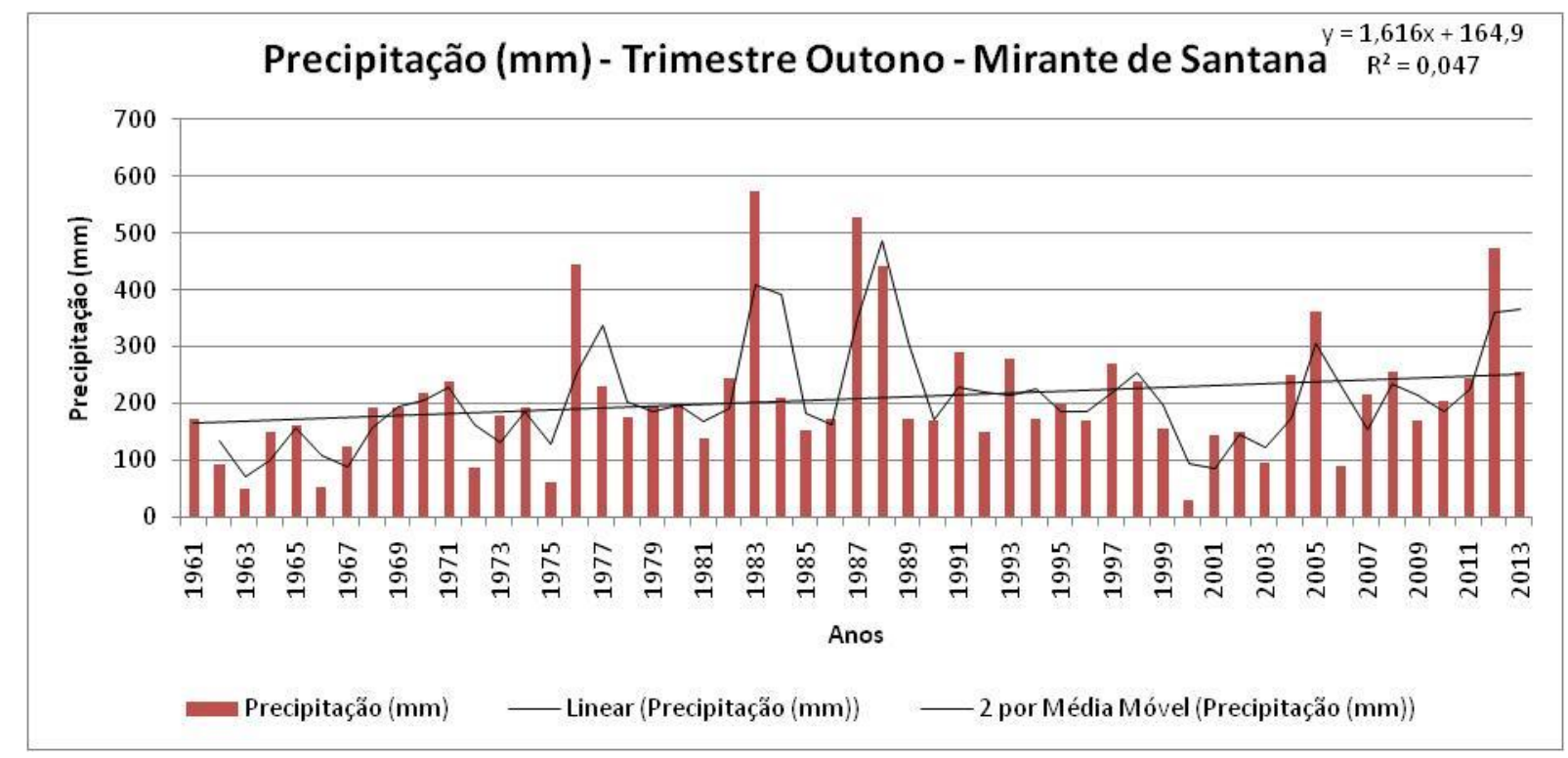

Gráfico 22: Valores trimestrais de alturas pluviométricas - Trimestre Outono - Mirante de Santana

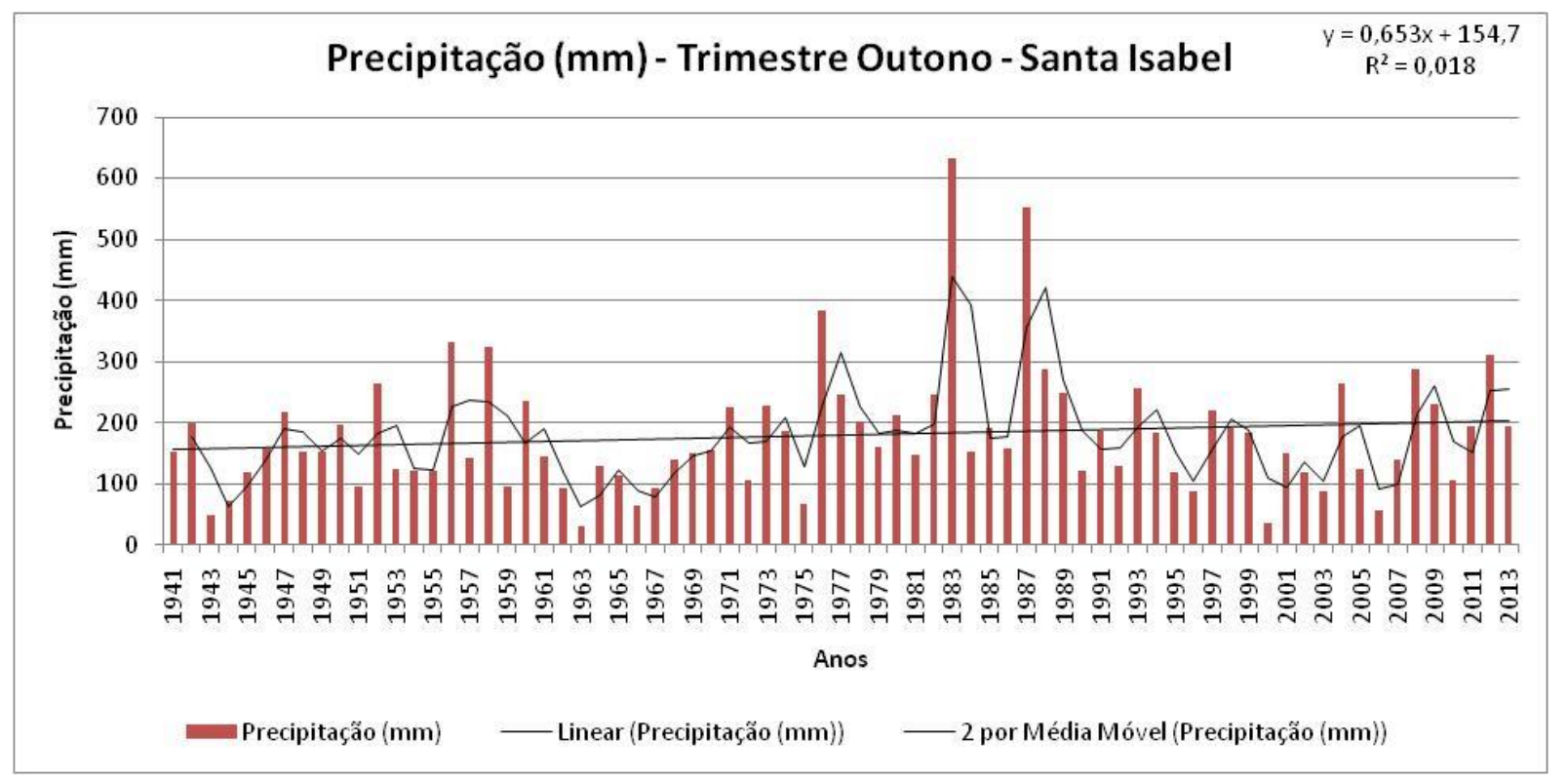

Gráfico 23: Valores trimestrais de alturas pluviométricas - Trimestre Outono - Santa Isabel 


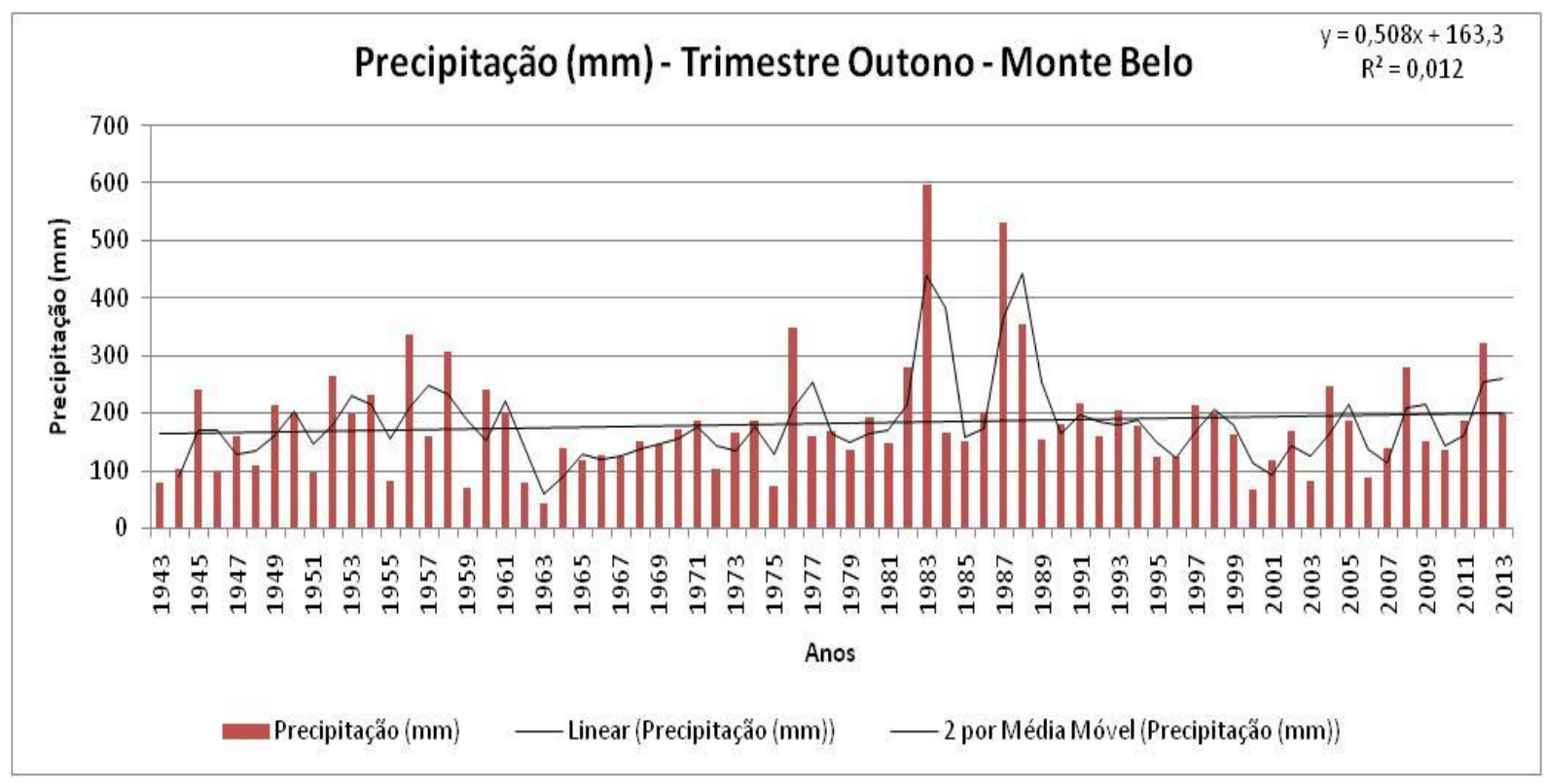

Gráfico 24: Valores trimestrais de alturas pluviométricas - Trimestre Outono - Monte Belo

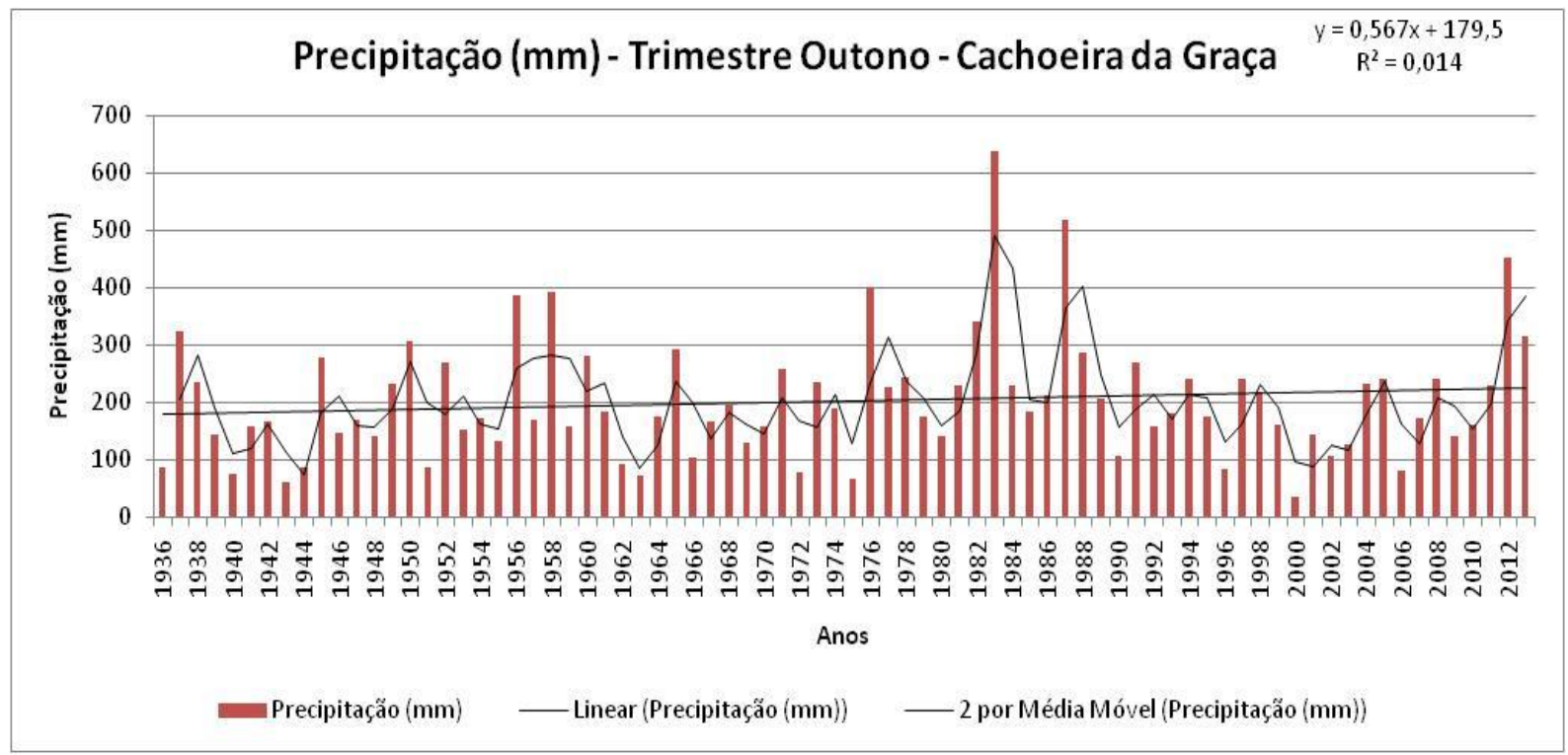

Gráfico 25: Valores trimestrais de alturas pluviométricas - Trimestre Outono Cachoeira da Graça

As séries de dados da estação meteorológica de Guarulhos e do posto pluviométrico Baixo Cotia apresentaram tendências nulas em relação às alturas pluviométricas (Gráficos 26 e 27), enquanto as séries dos postos Juquitiba e Ponte Nova apresentaram tendências negativas (Gráficos 28 e 29) de precipitação para o trimestre de outono. 


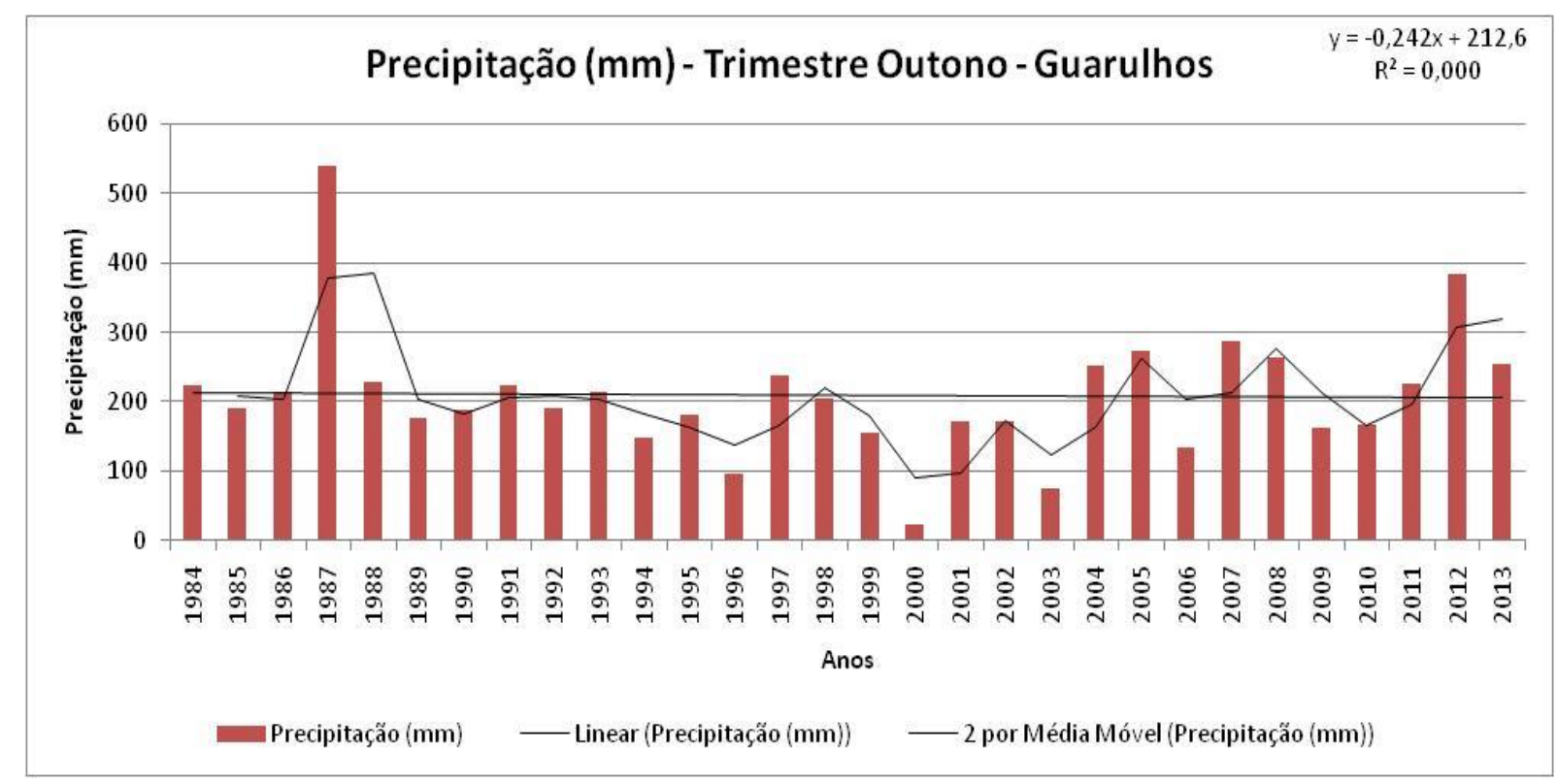

Gráfico 26: Valores trimestrais de alturas pluviométricas - Trimestre Outono Guarulhos

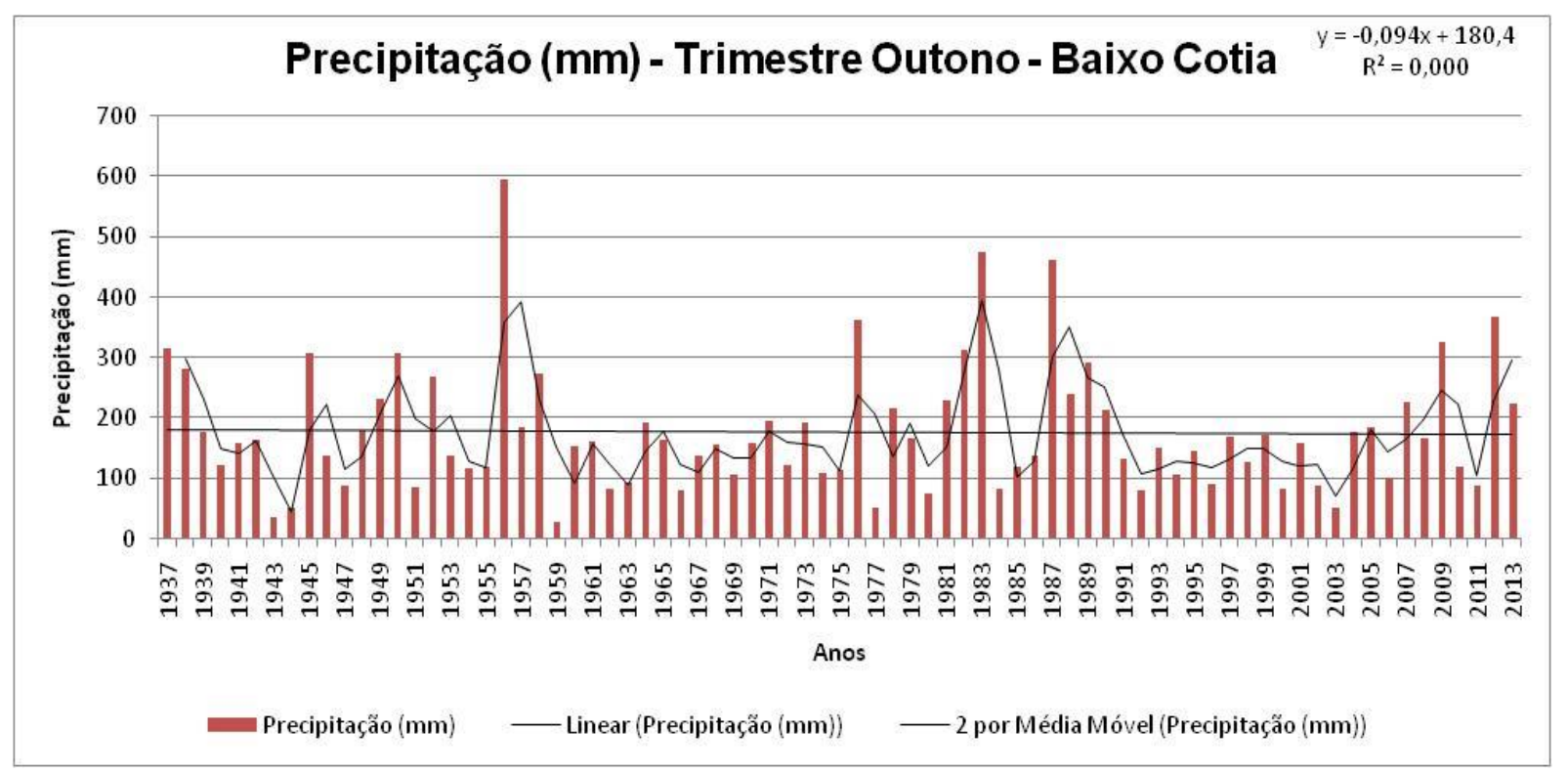

Gráfico 27: Valores trimestrais de alturas pluviométricas - Trimestre Outono - Baixo Cotia 


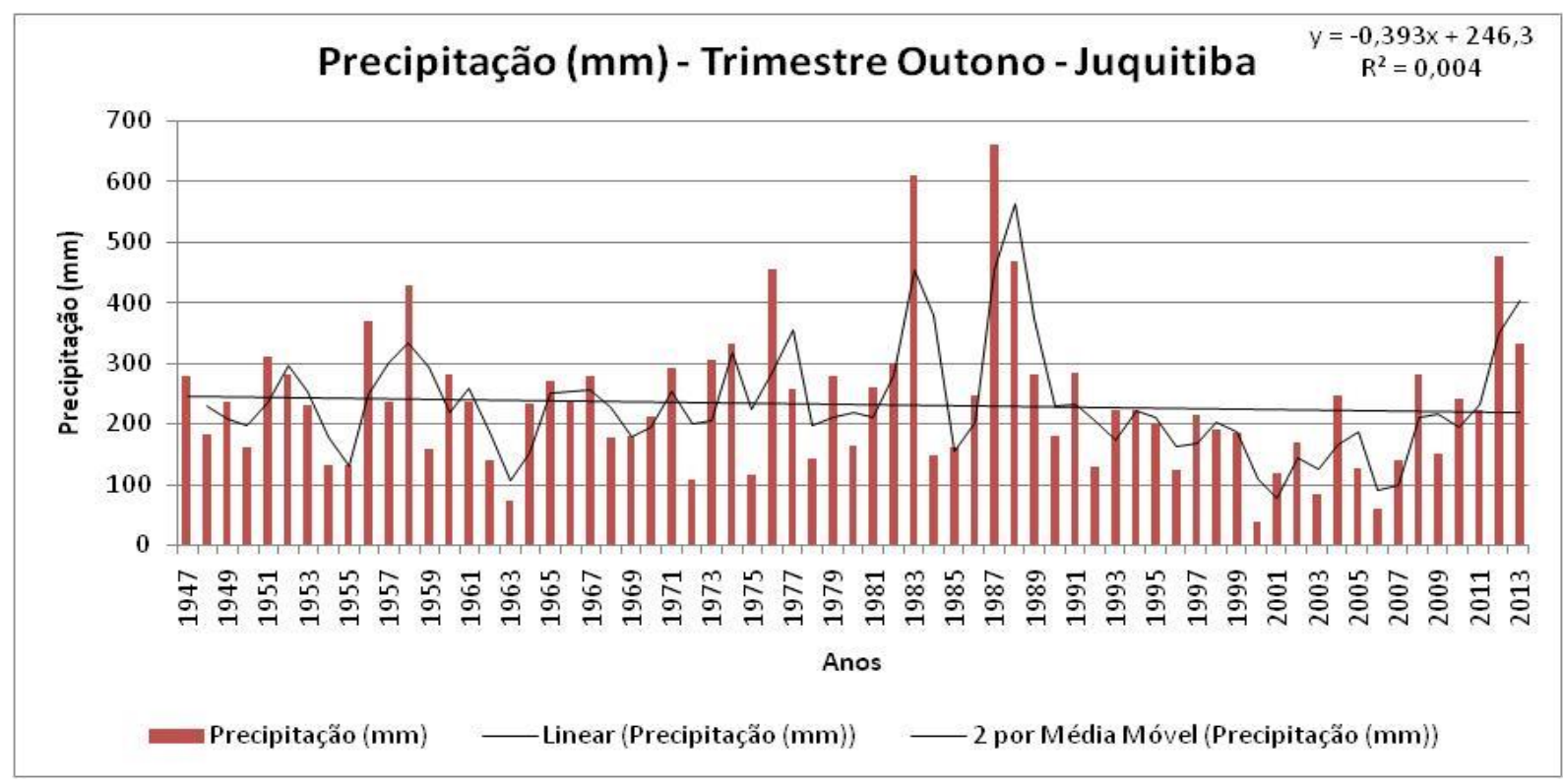

Gráfico 28: Valores trimestrais de alturas pluviométricas - Trimestre Outono - Juquitiba

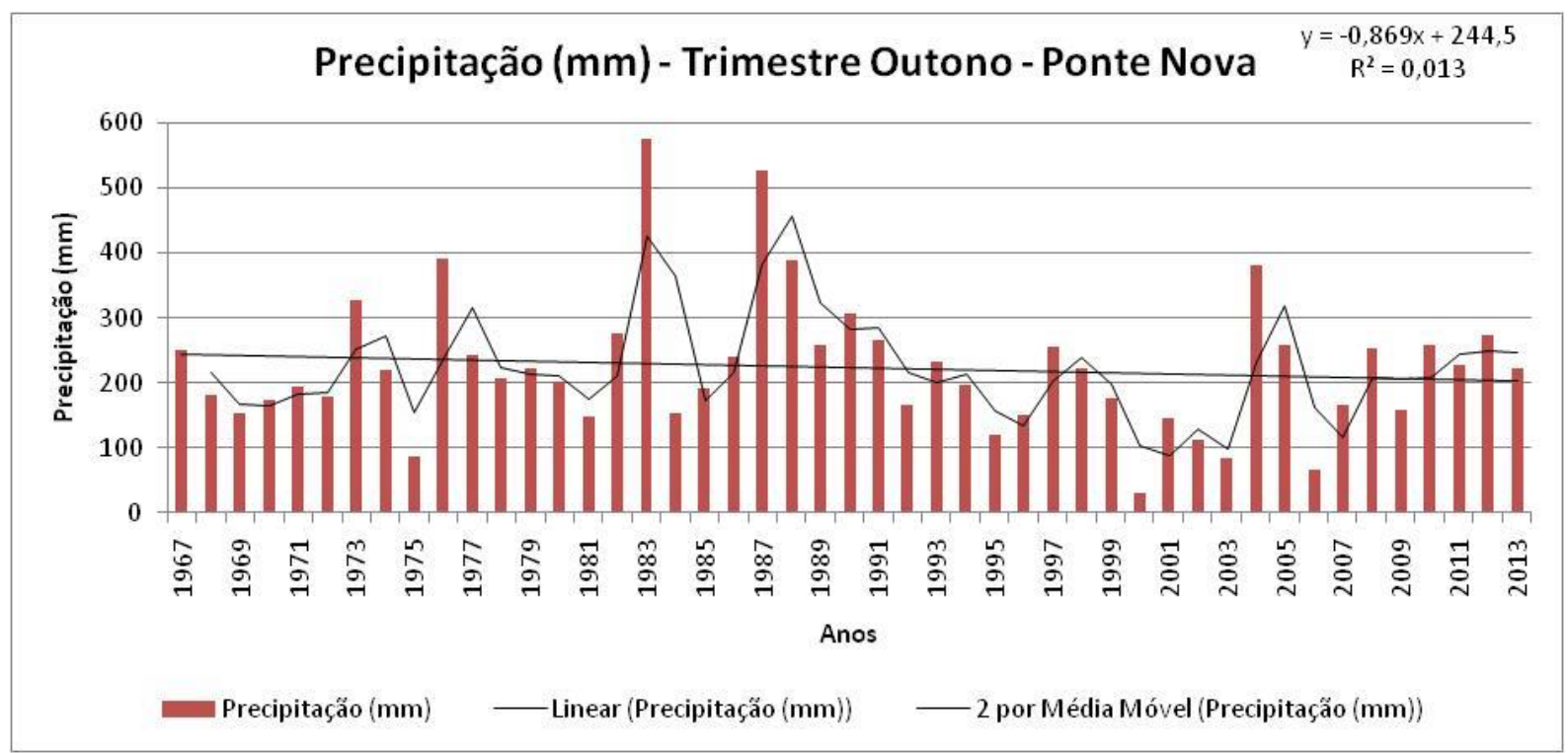

Gráfico 29: Valores trimestrais de alturas pluviométricas - Trimestre Outono - Ponte Nova

Já o trimestre de inverno (julho a setembro), caracteristicamente o menos chuvoso para a região, apresentou cinco séries de dados com tendências positivas para o aumento de precipitação (Baixo Cotia, Cachoeira da Graça, Santa Isabel, IAG e Mirante de Santana) (Gráficos 30, 31, 32, 33, 34), quatro séries com tendência nula (Monte Belo, Fazenda São Bento, Guarulhos e 
Juquitiba) (Gráficos 35, 36, 37 e 38) e uma com tendência negativa (Ponte Nova) (Gráfico 39).

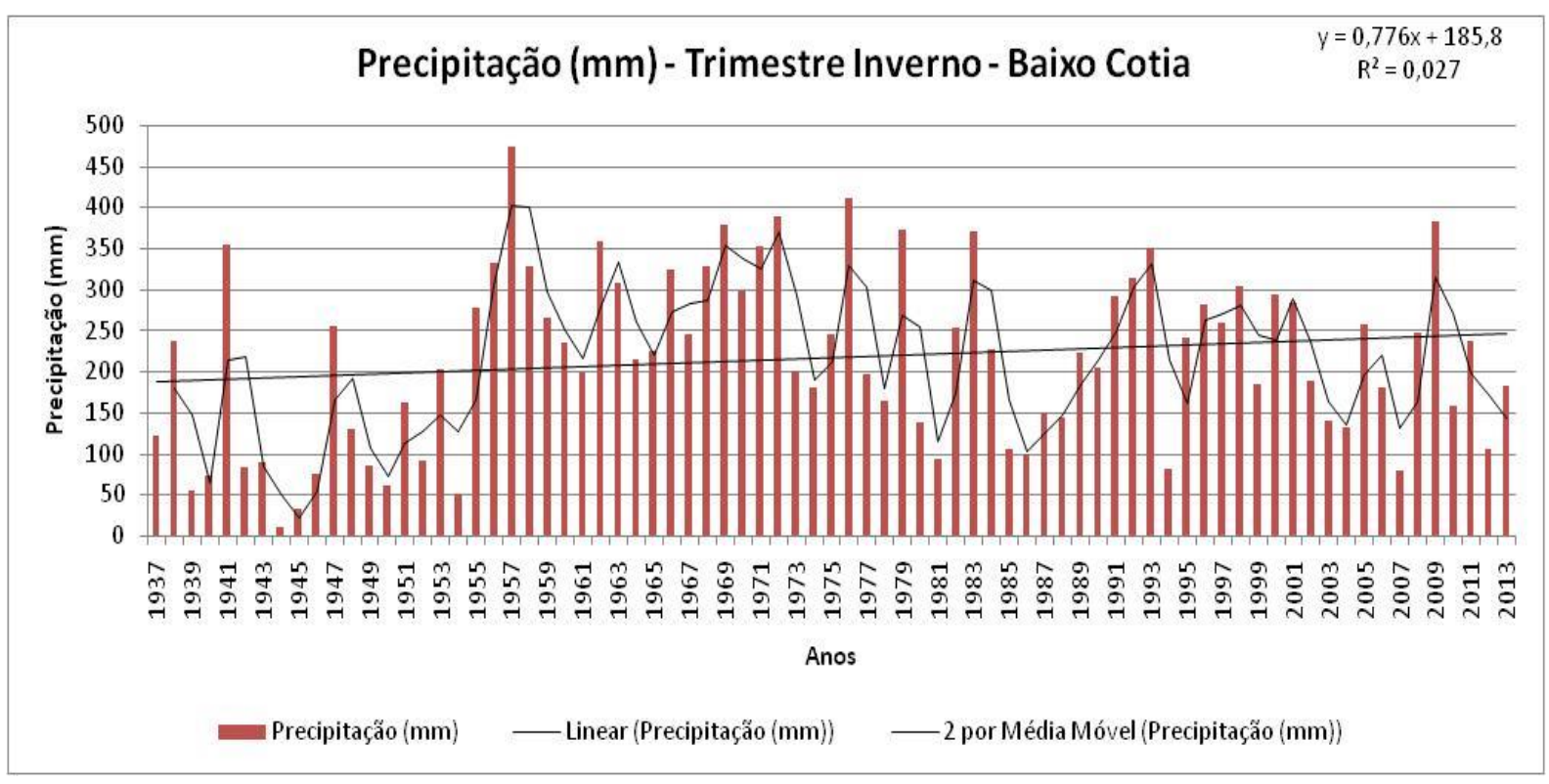

Gráfico 30: Valores trimestrais de alturas pluviométricas - Trimestre Inverno - Baixo Cotia

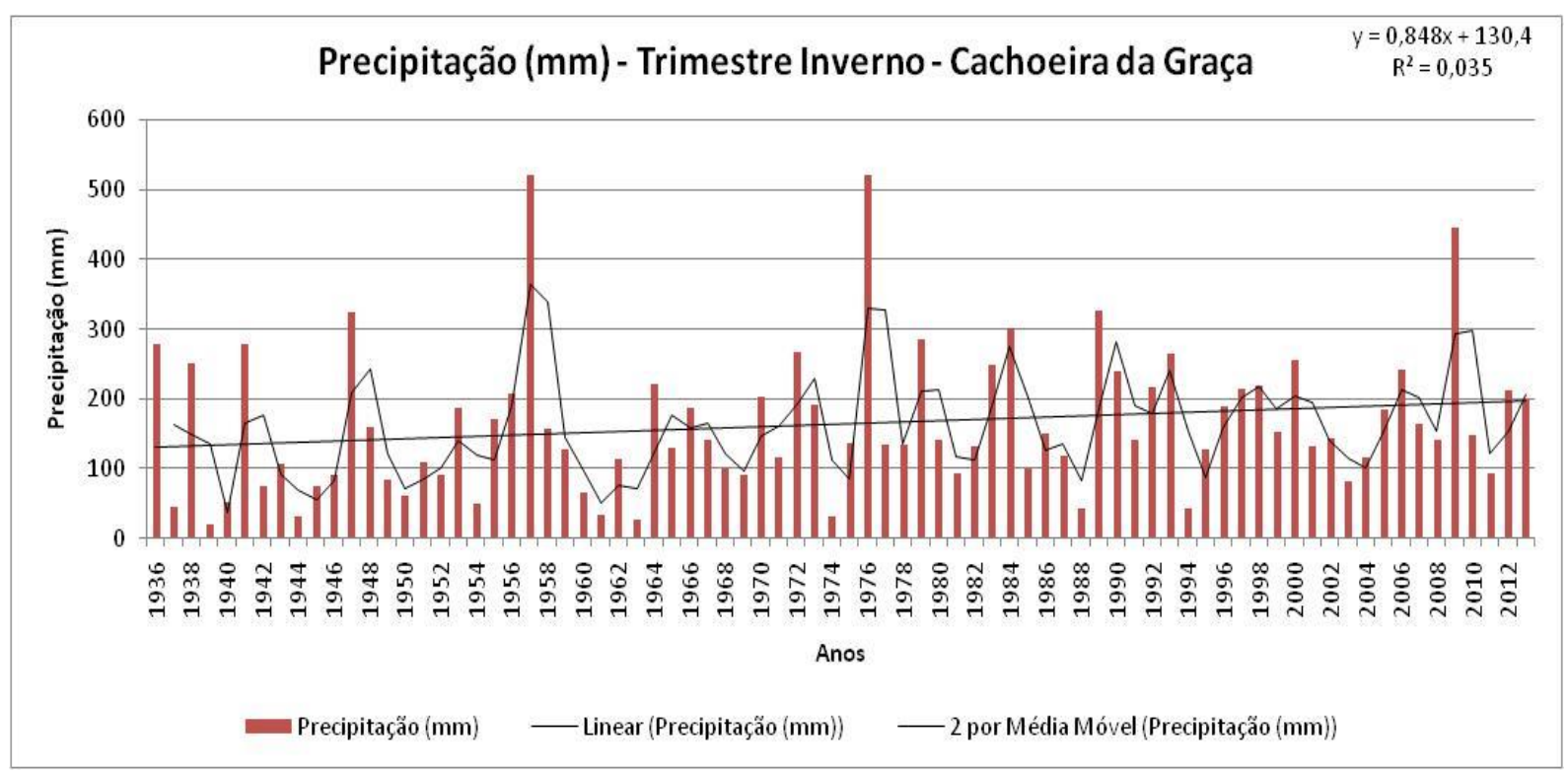

Gráfico 31: Valores trimestrais de alturas pluviométricas - Trimestre Inverno Cachoeira da Graça 


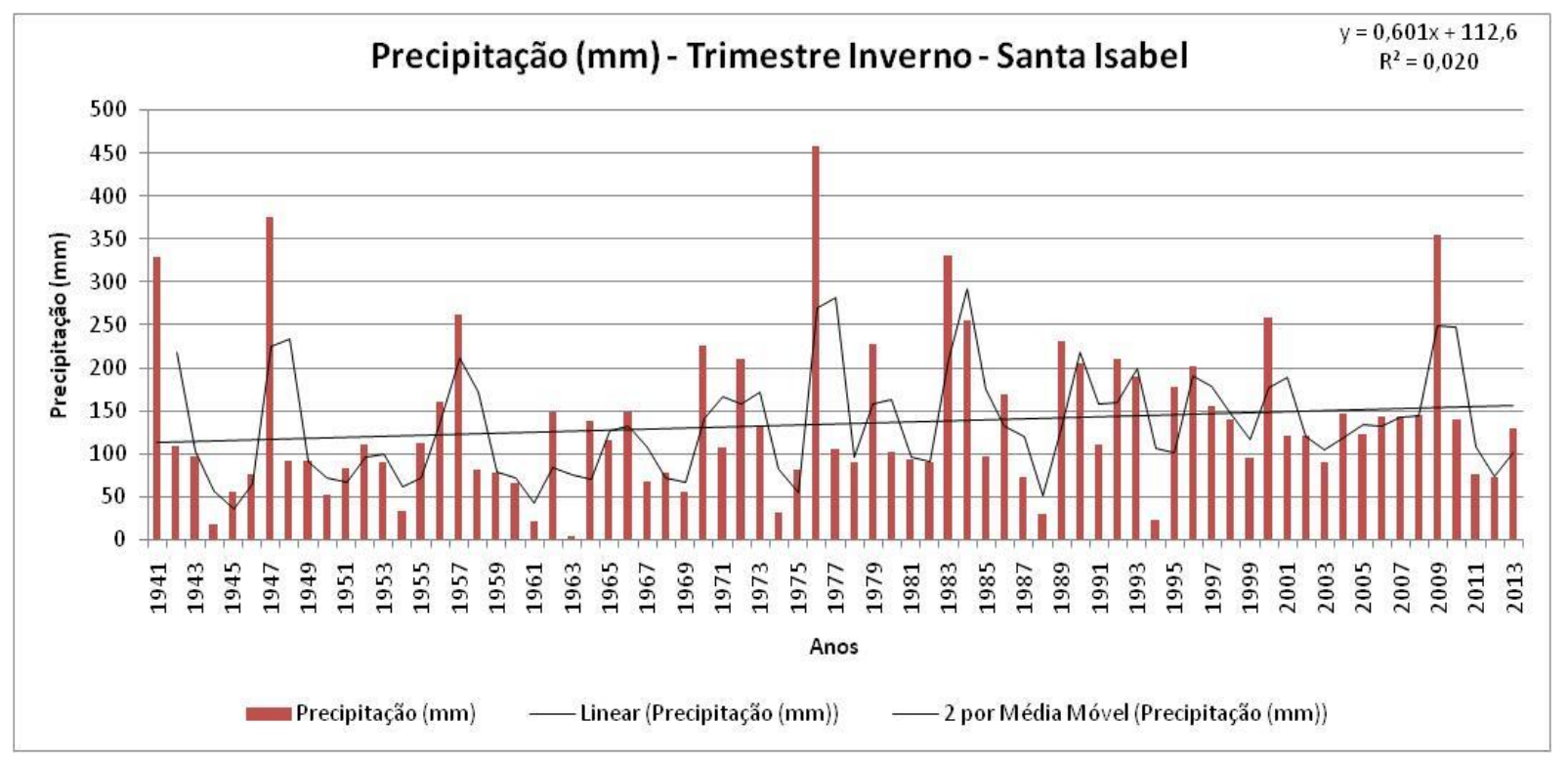

Gráfico 32: Valores trimestrais de alturas pluviométricas - Trimestre Inverno - Santa Isabel

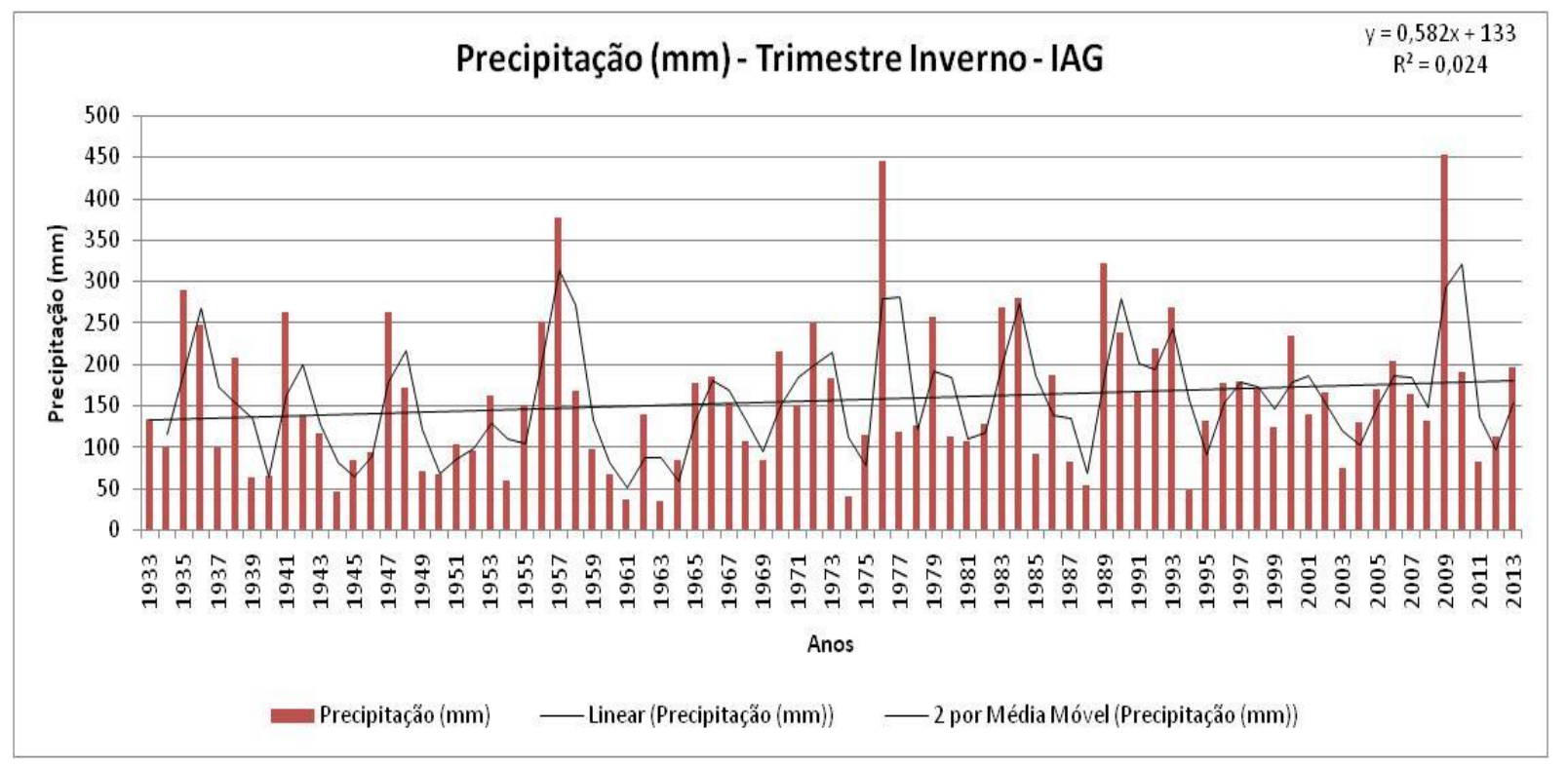

Gráfico 33: Valores trimestrais de alturas pluviométricas - Trimestre Inverno - IAG 


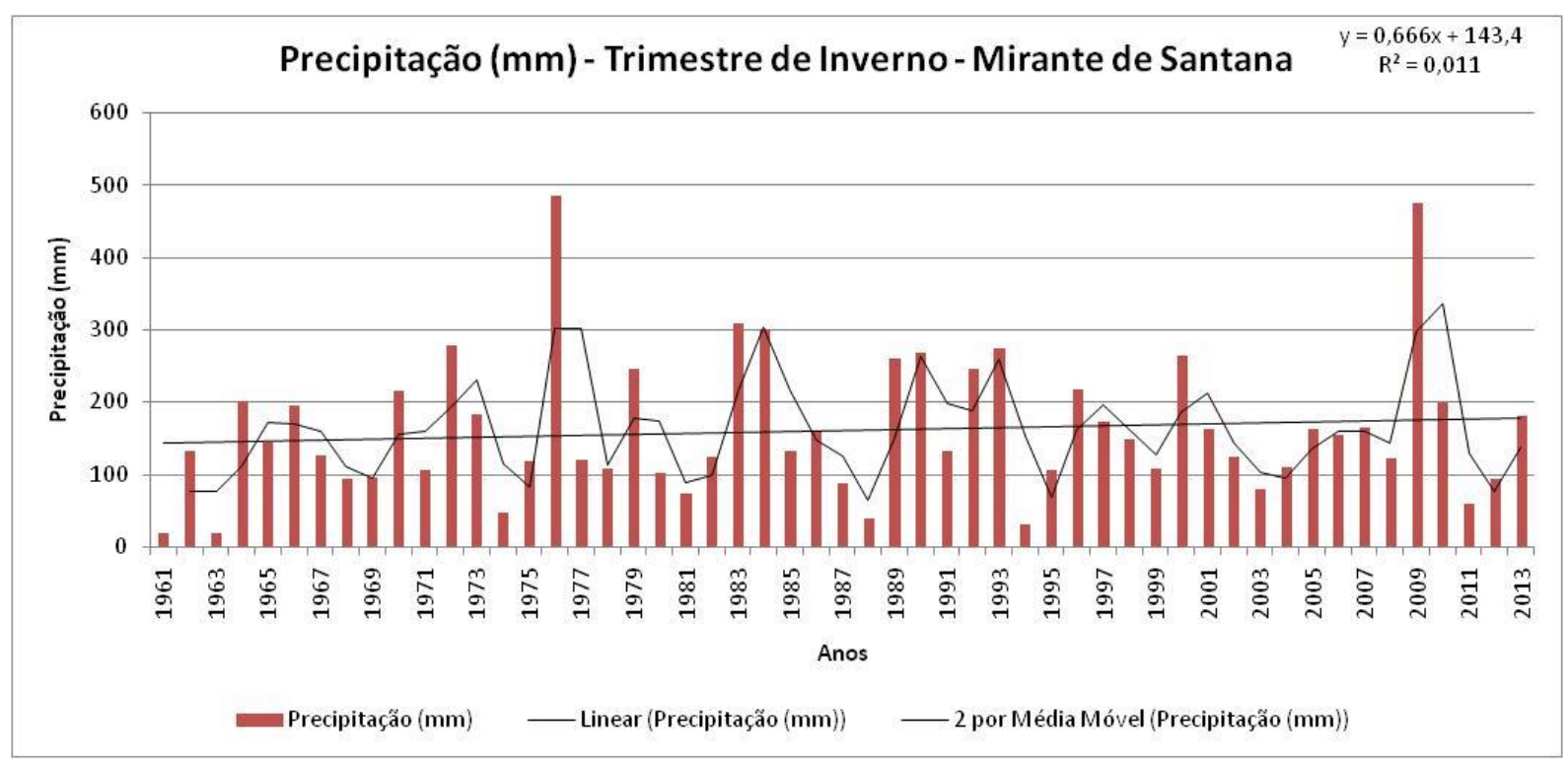

Gráfico 34: Valores trimestrais de alturas pluviométricas - Trimestre Inverno - Mirante de Santana

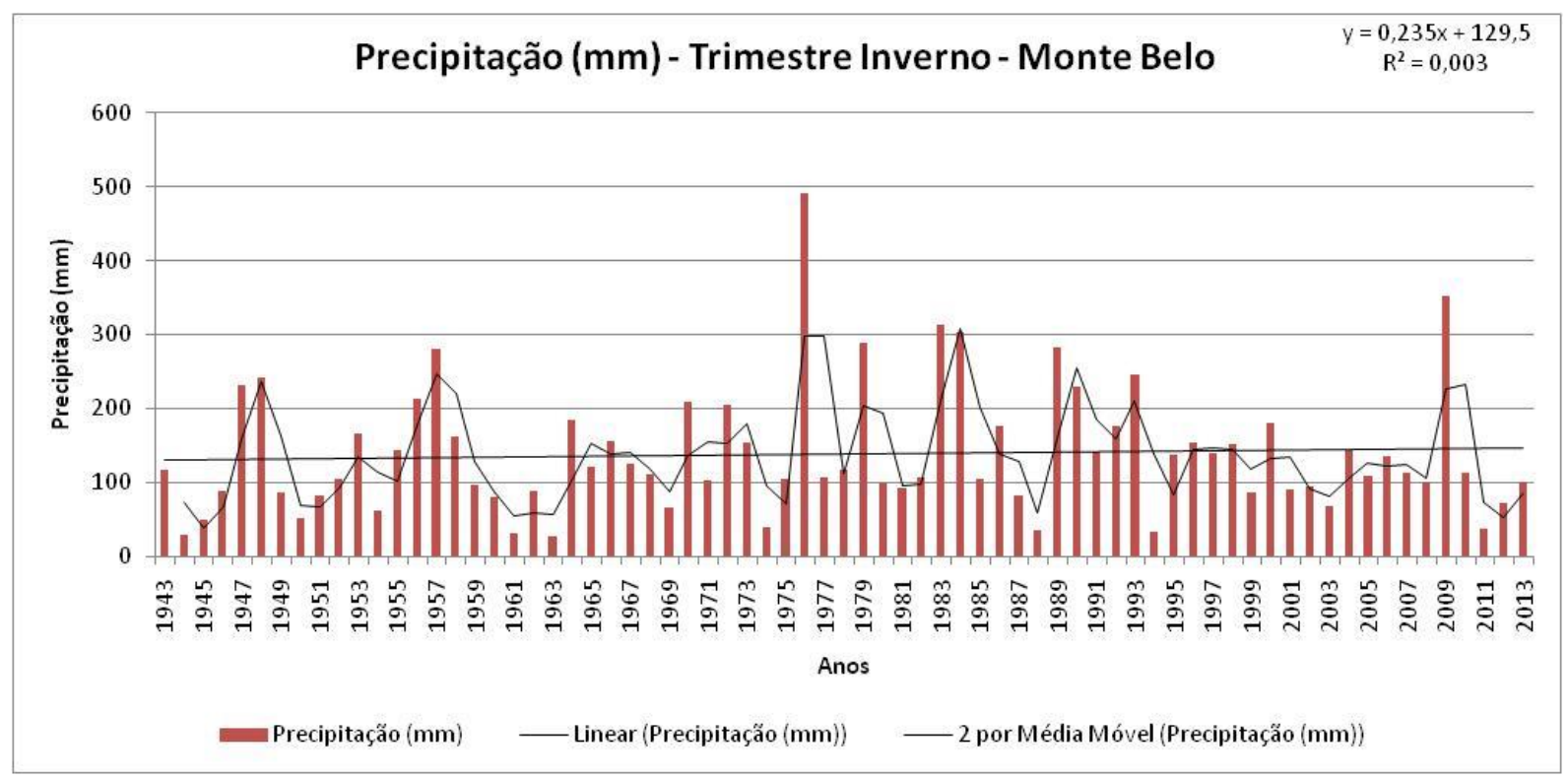

Gráfico 35: Valores trimestrais de alturas pluviométricas - Trimestre Inverno - Monte Belo 


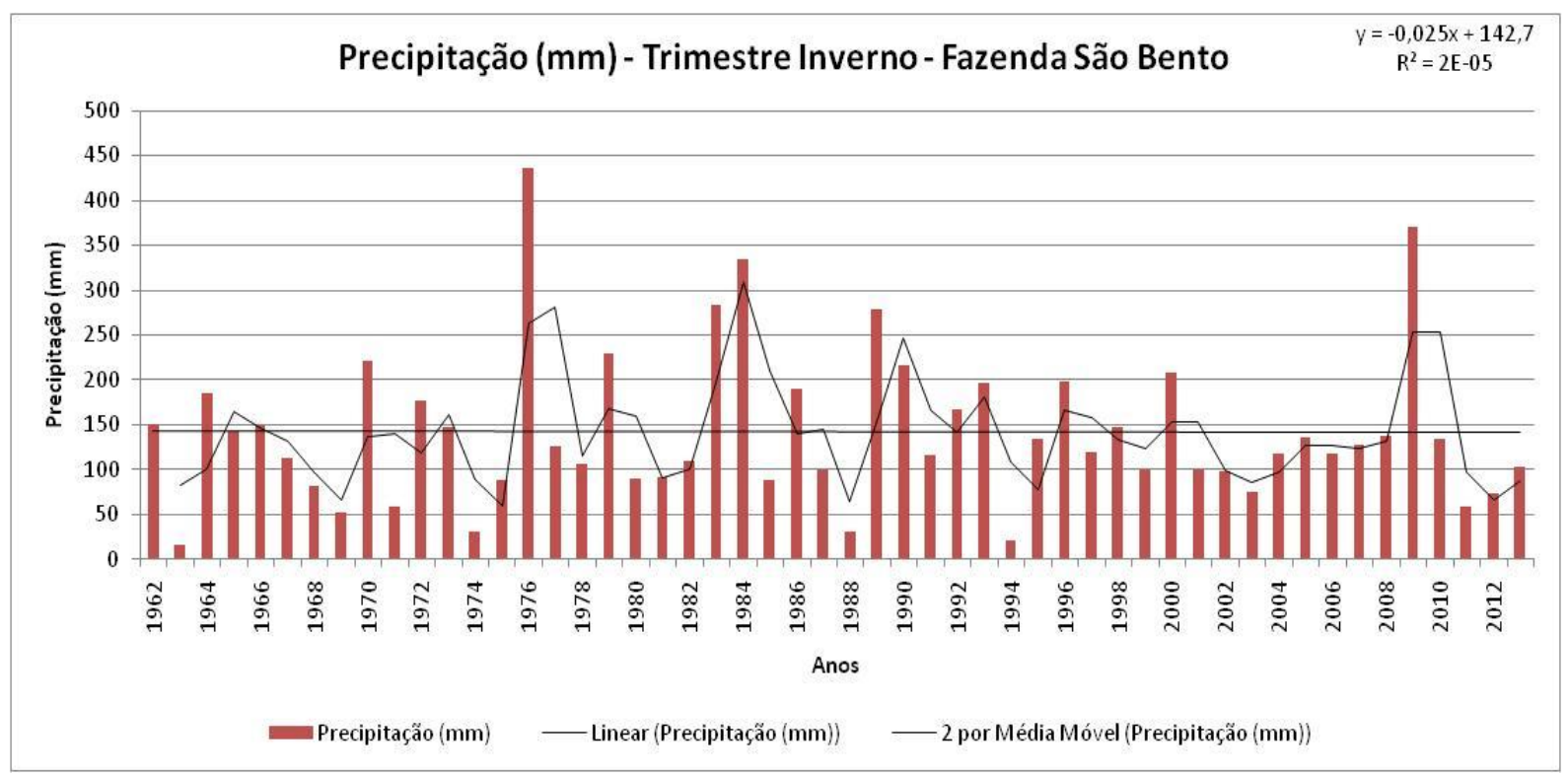

Gráfico 36: Valores trimestrais de alturas pluviométricas - Trimestre Inverno - Fazenda São Bento

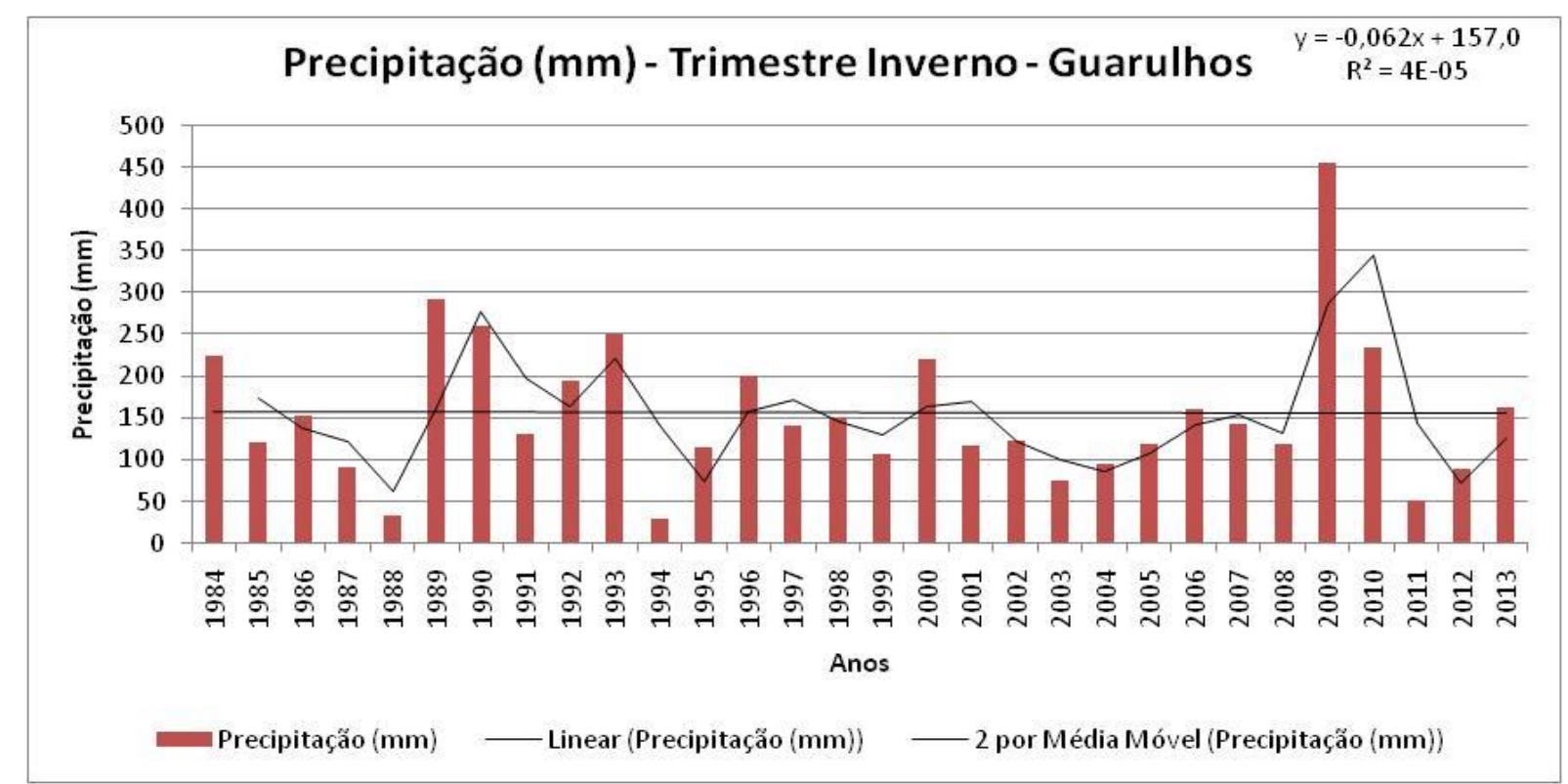

Gráfico 37: Valores trimestrais de alturas pluviométricas - Trimestre Inverno Guarulhos 


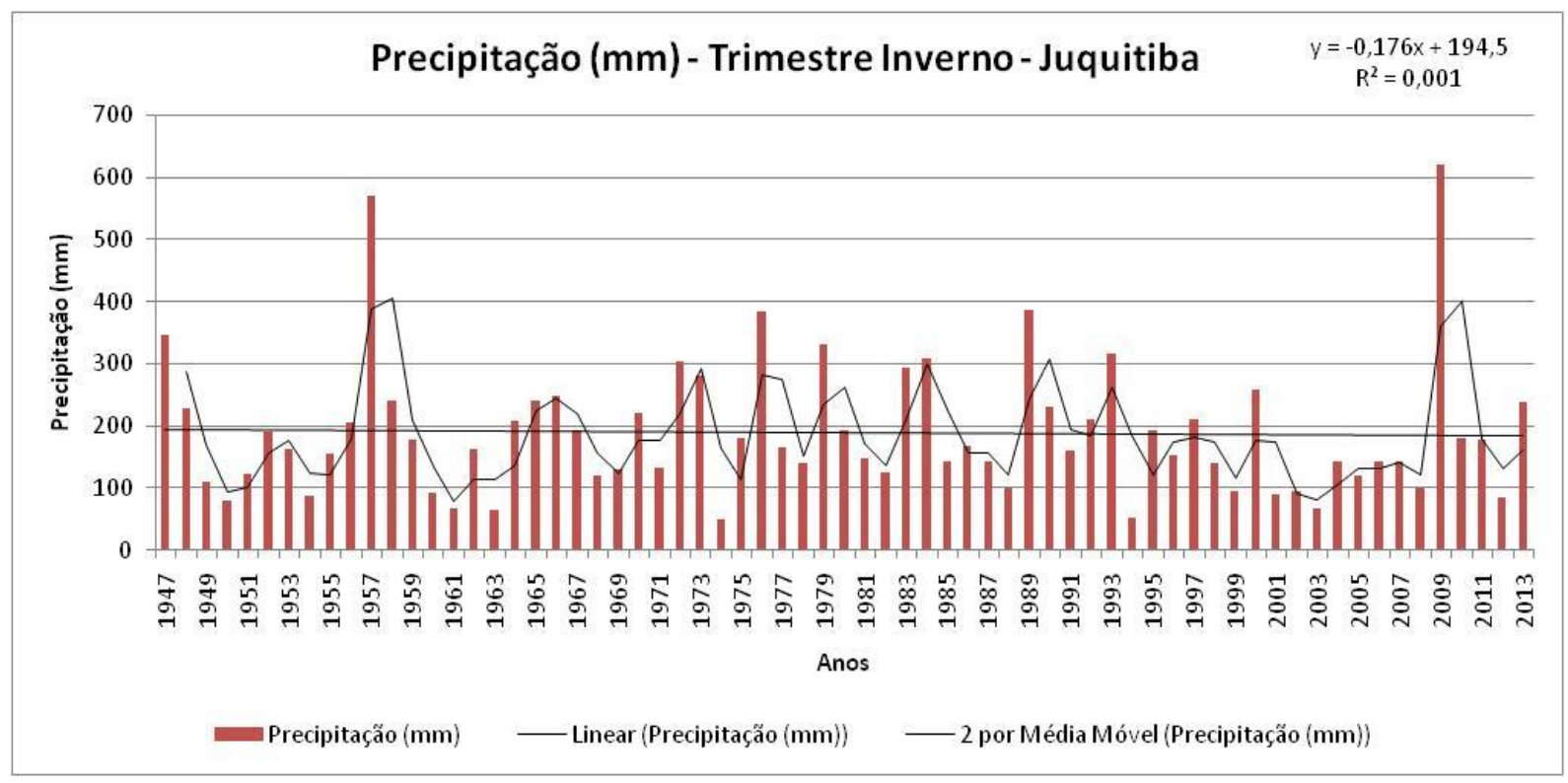

Gráfico 38: Valores trimestrais de alturas pluviométricas - Trimestre Inverno - Juquitiba

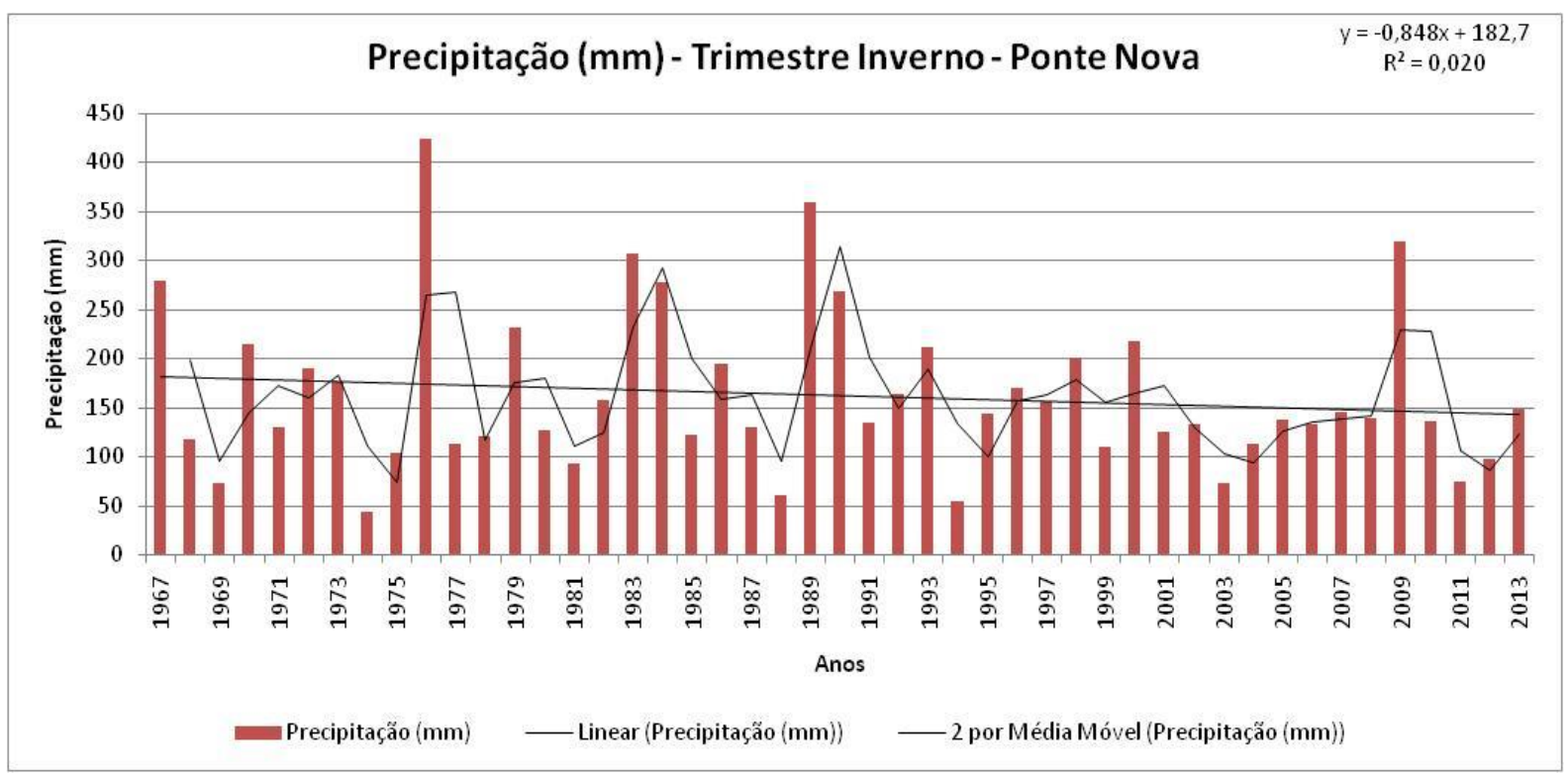

Gráfico 39: Valores trimestrais de alturas pluviométricas - Trimestre Inverno - Ponte Nova

Por fim, as séries relativas à primavera, trimestre que vai de outubro a dezembro e se caracteriza pelo aumento gradativo das chuvas e das temperaturas em relação ao inverno, não apresentaram nenhuma tendência negativa, sendo cinco delas com tendências positivas (Guarulhos, Mirante de Santana, IAG, Santa Isabel e Baixo Cotia) (Gráficos 40, 41, 42, 43 e 44) e as 
demais com tendências nulas (Juquitiba, Fazenda São Bento, Monte Belo, Cachoeira da Graça e Ponte Nova) (Gráficos 45, 46, 47, 48 e 49).

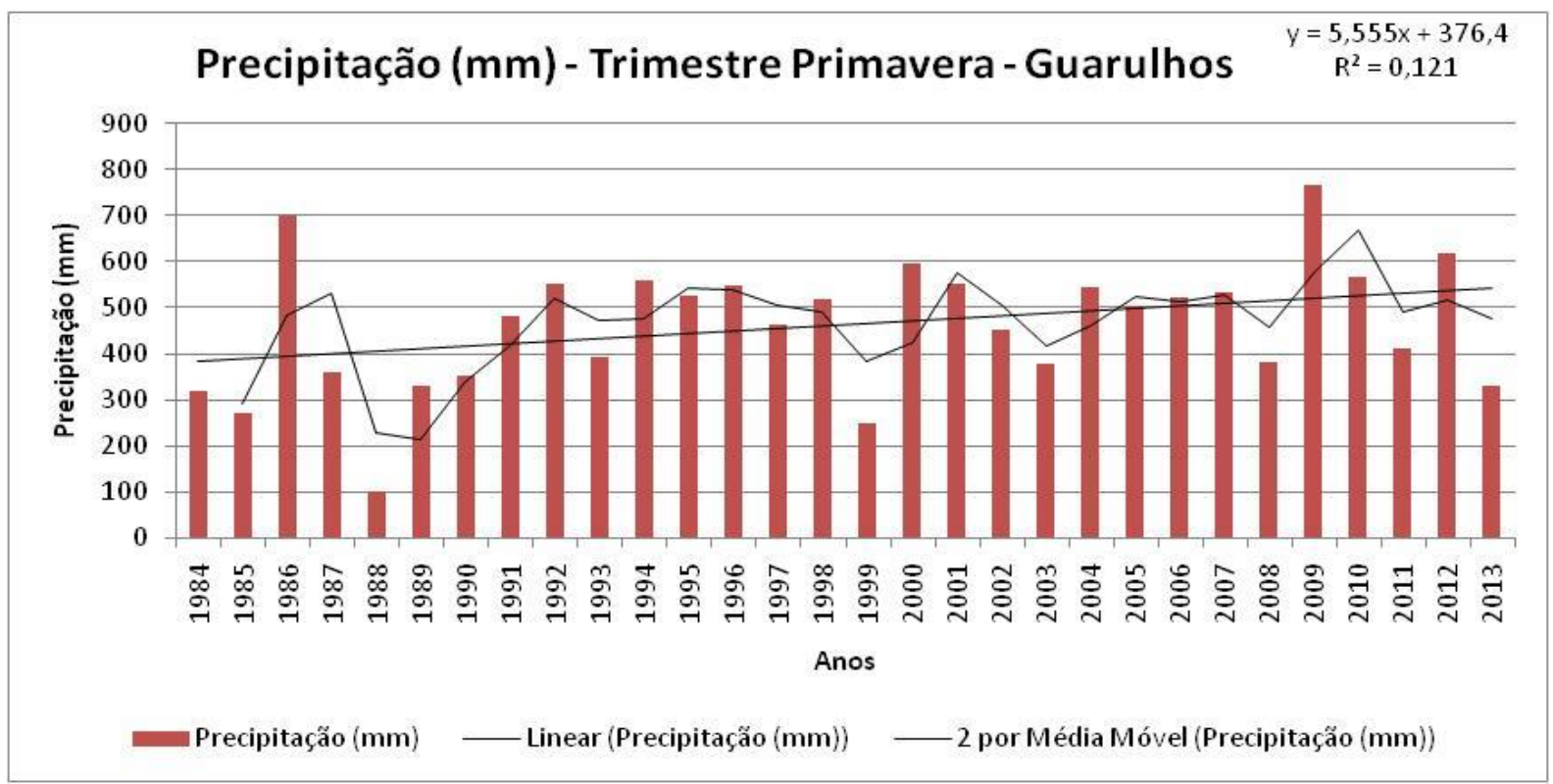

Gráfico 40: Valores trimestrais de alturas pluviométricas - Trimestre Primavera Guarulhos

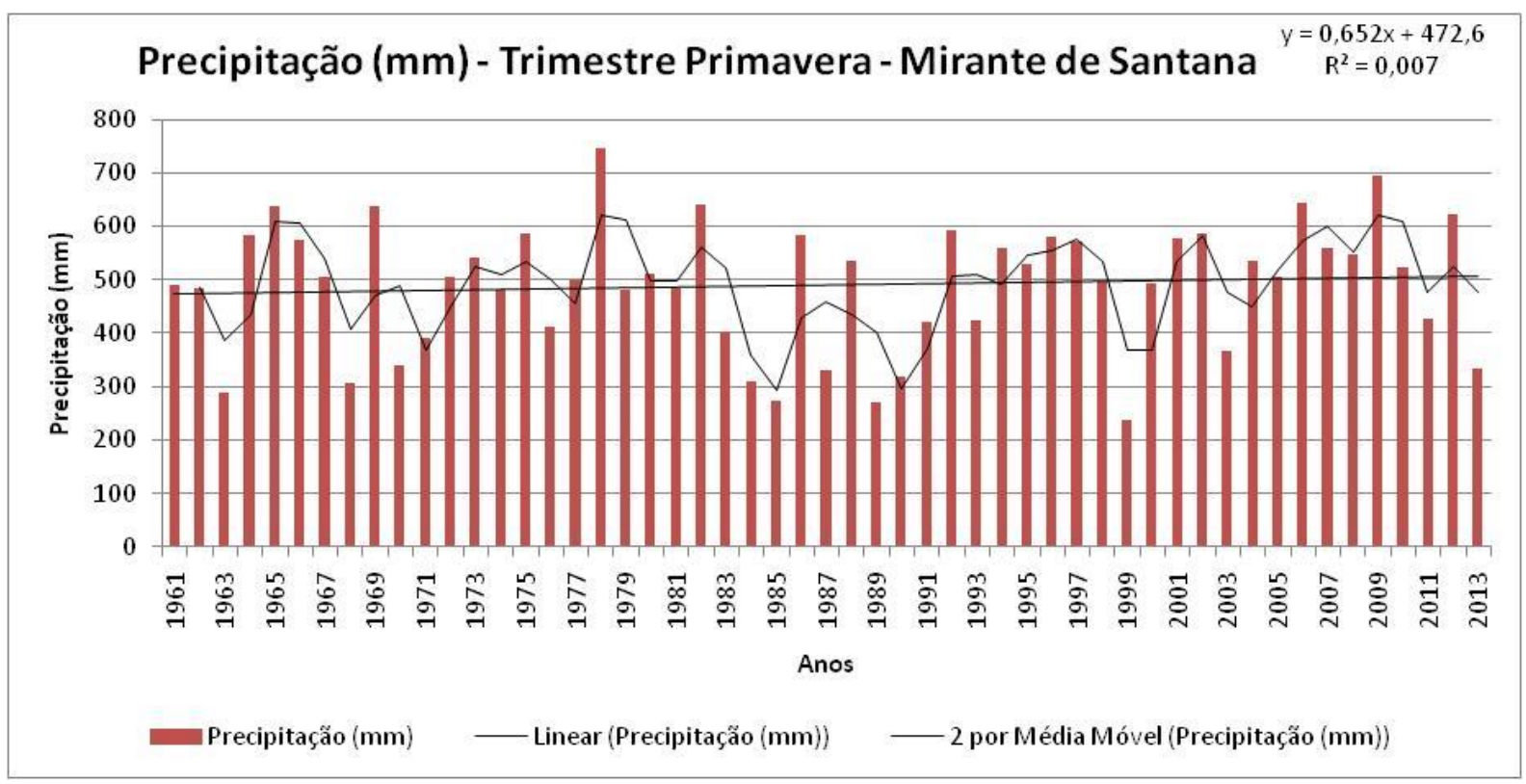

Gráfico 41: Valores trimestrais de alturas pluviométricas - Trimestre Primavera Mirante de Santana 


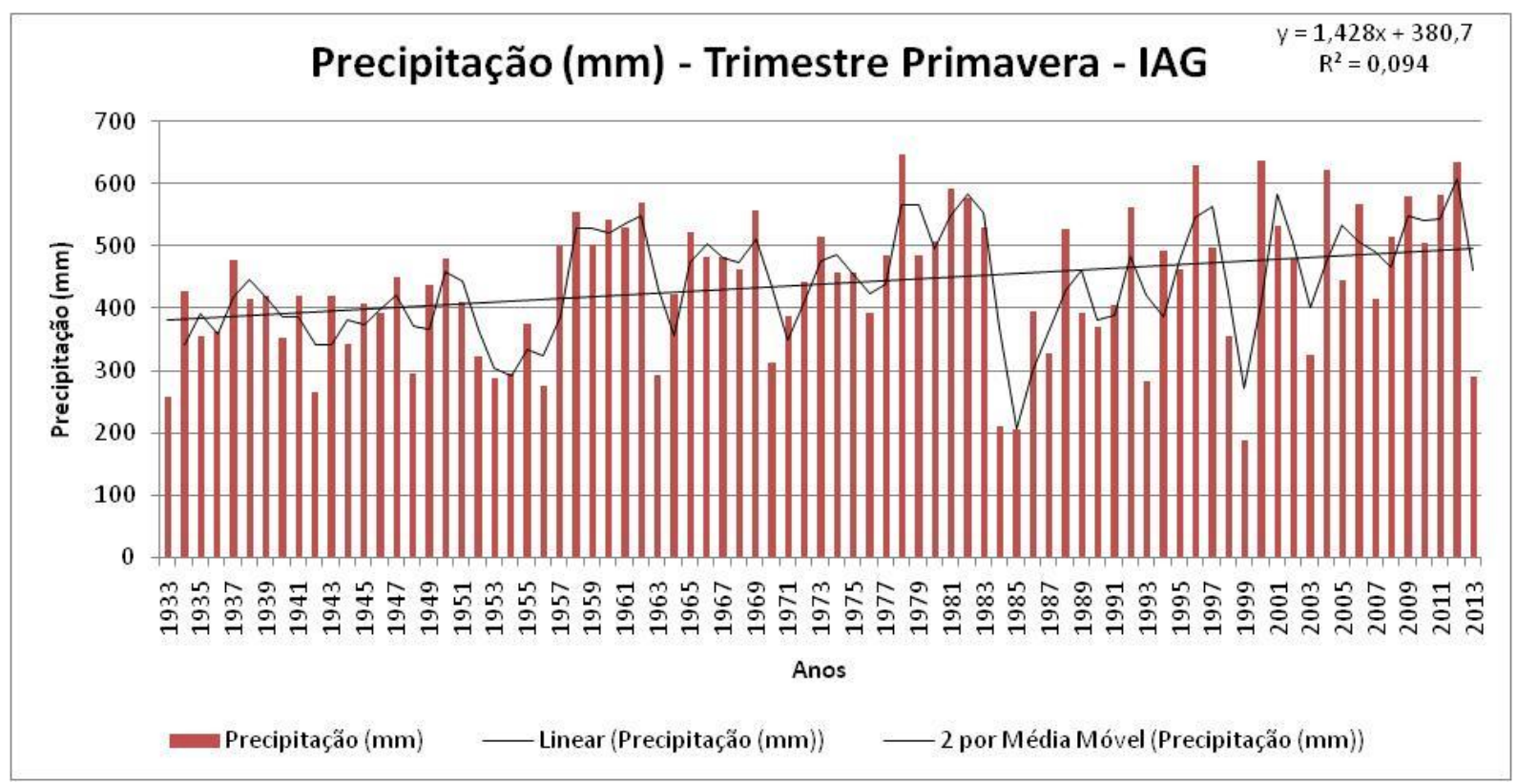

Gráfico 42: Valores trimestrais de alturas pluviométricas - Trimestre Primavera - IAG

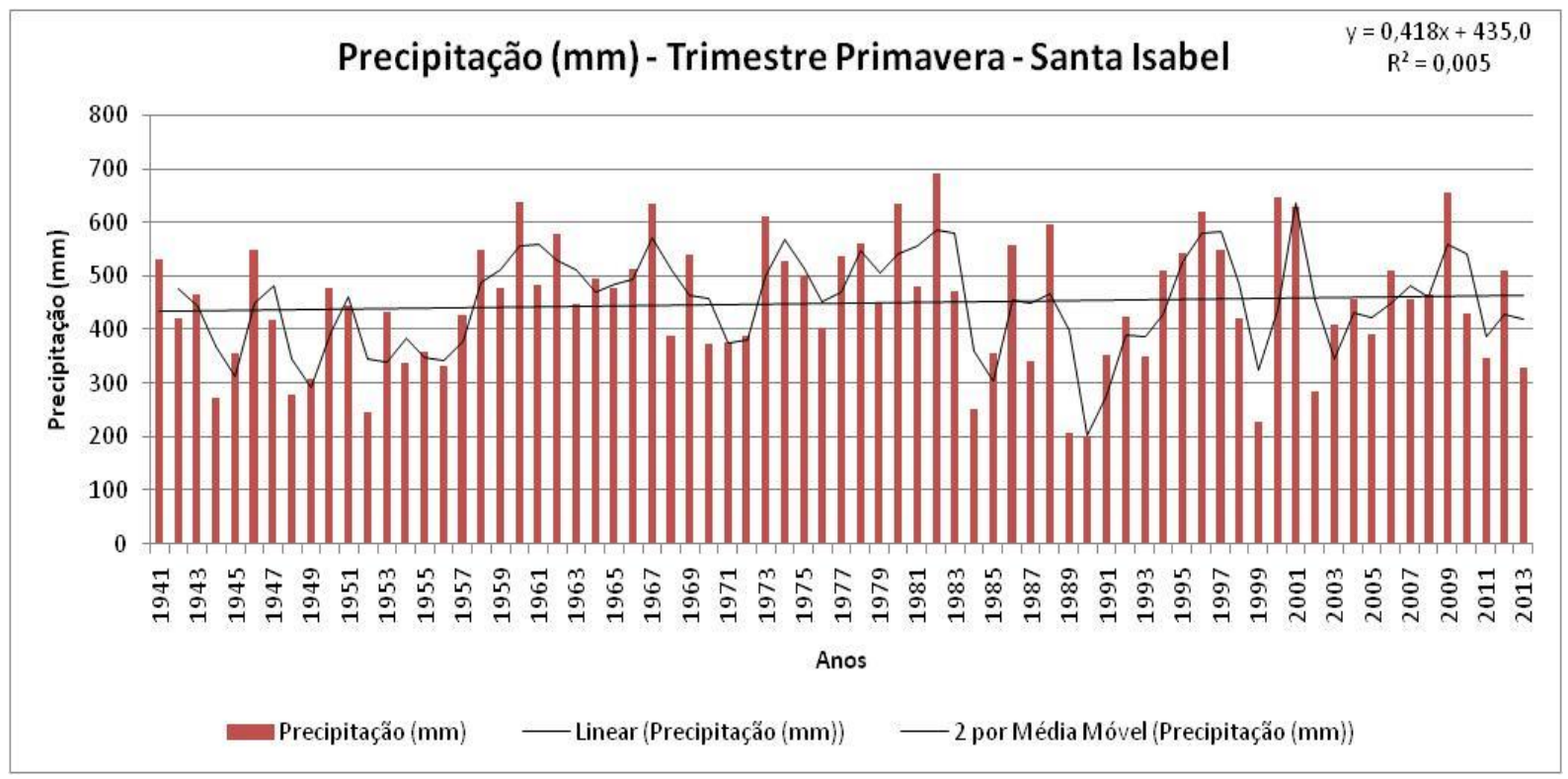

Gráfico 43: Valores trimestrais de alturas pluviométricas - Trimestre Primavera - Santa Isabel 


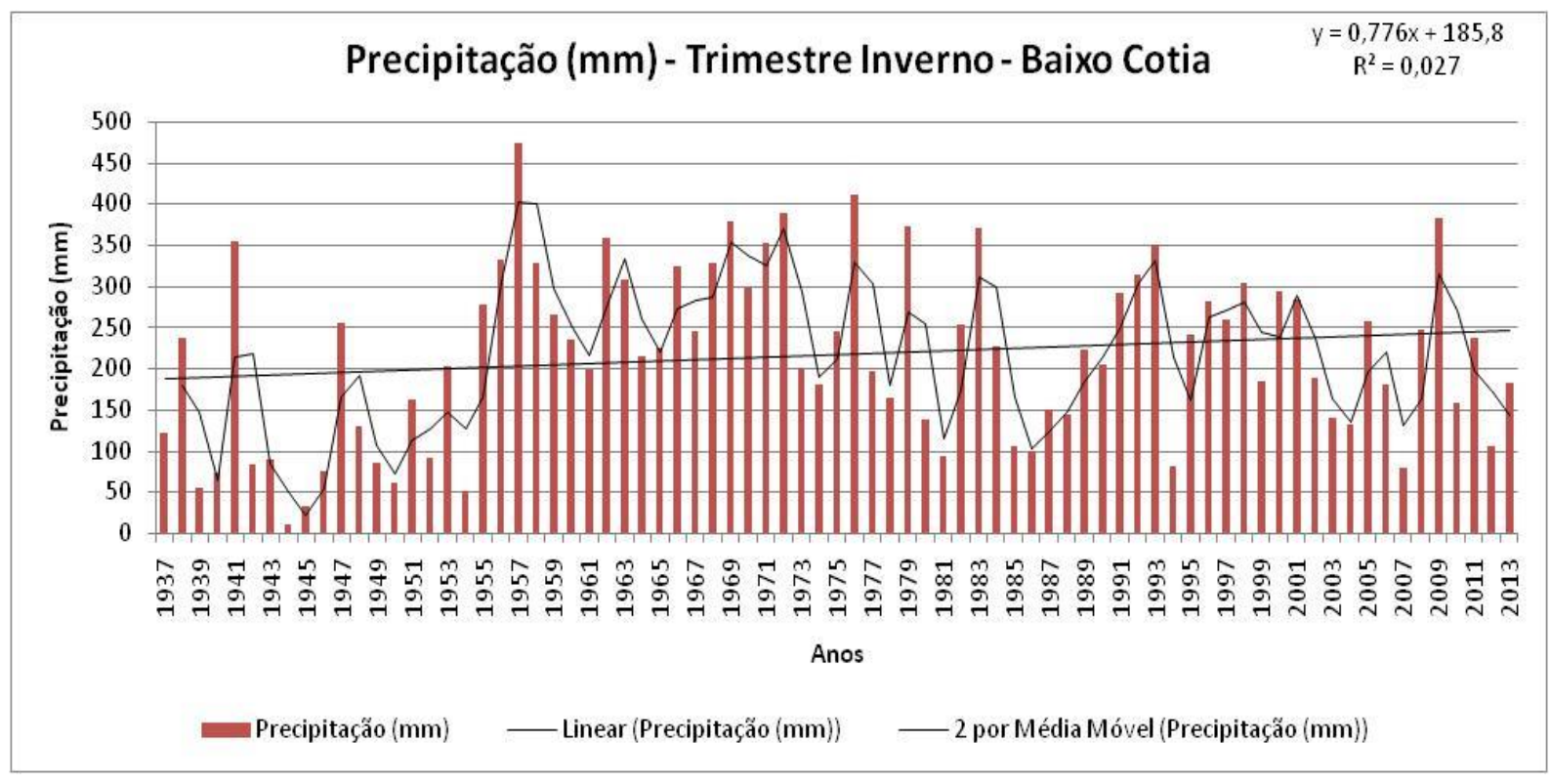

Gráfico 44: Valores trimestrais de alturas pluviométricas - Trimestre Primavera - Baixo Cotia

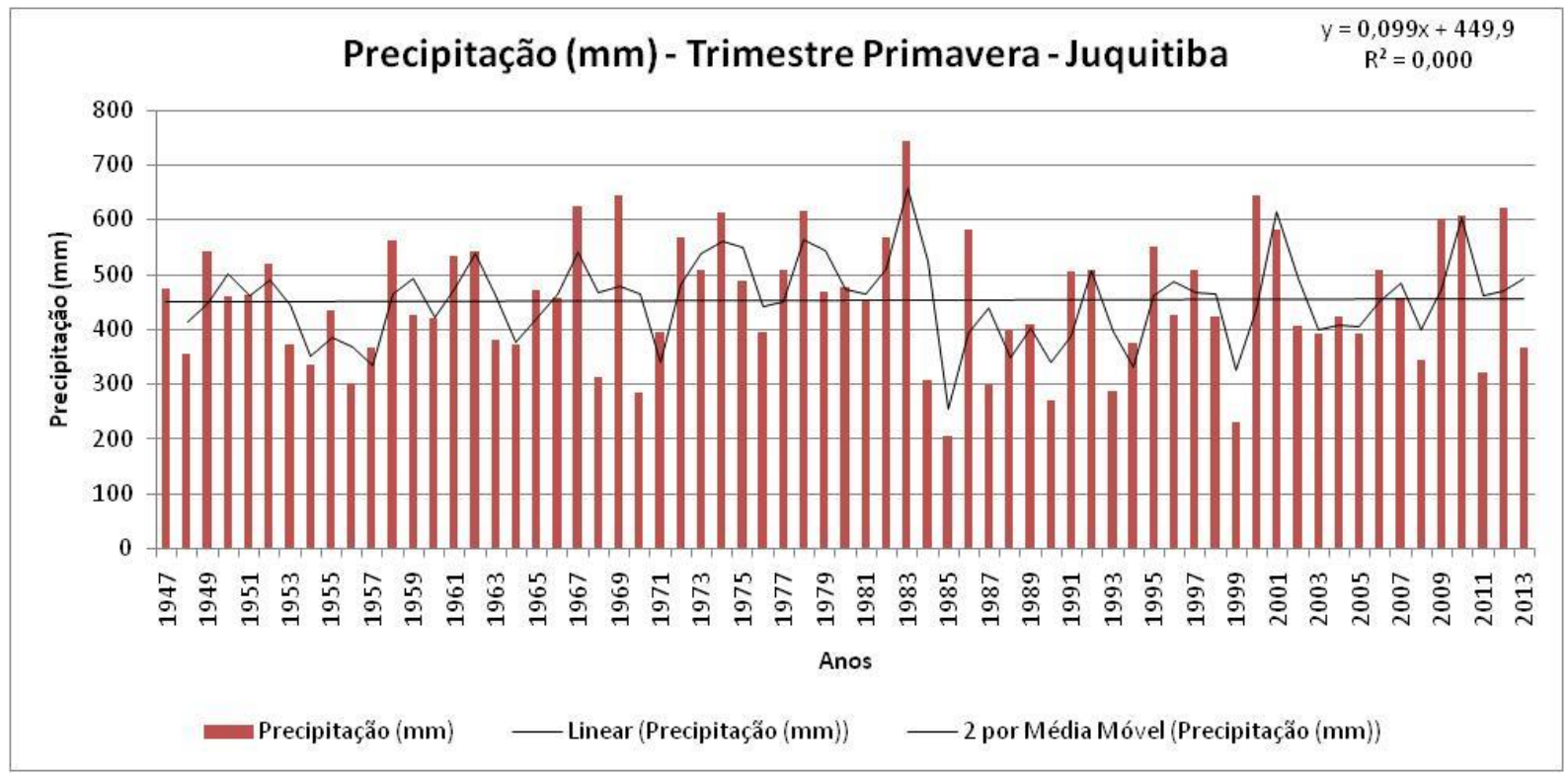

Gráfico 45: Valores trimestrais de alturas pluviométricas - Trimestre Primavera Juquitiba 


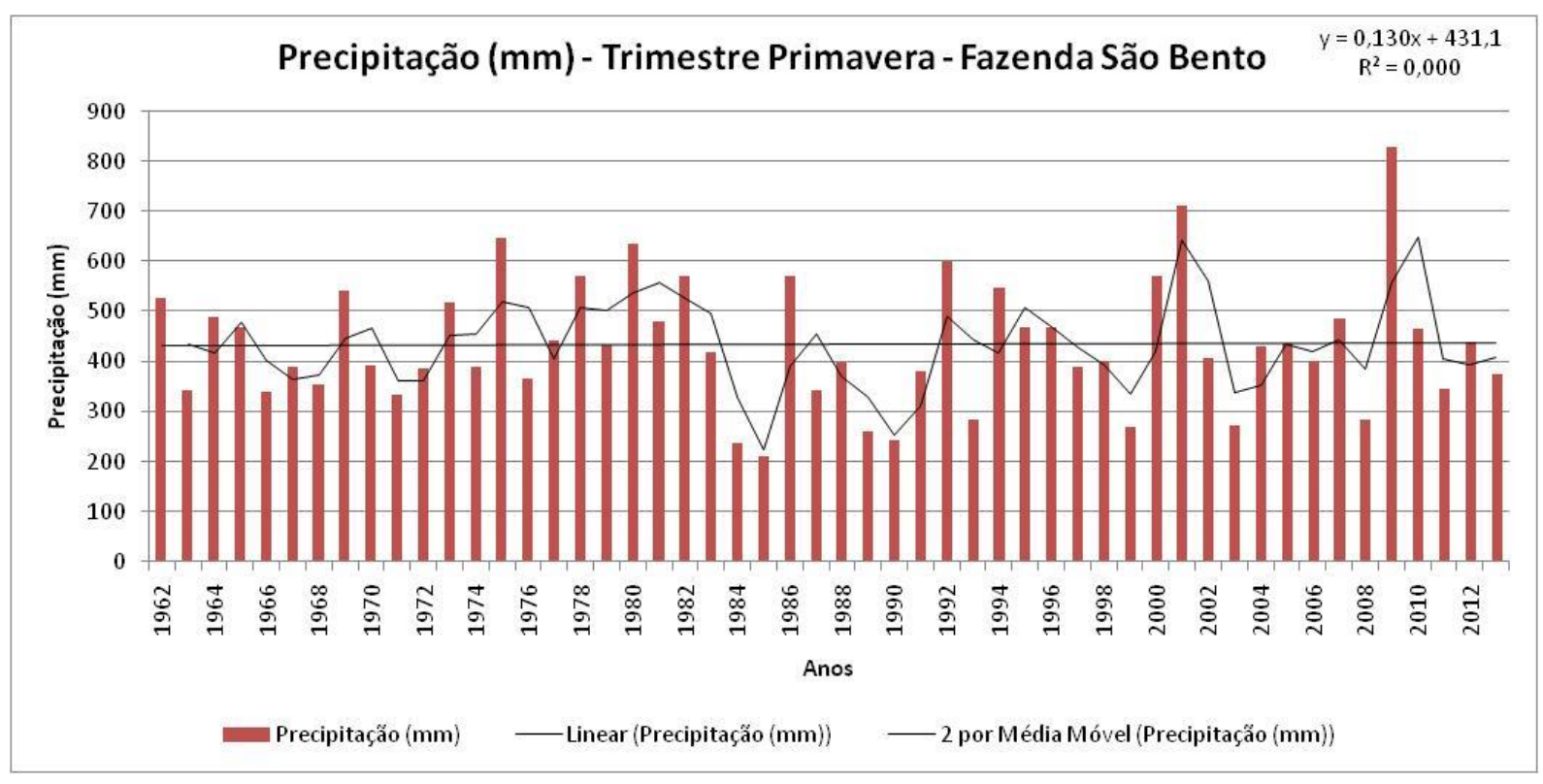

Gráfico 46: Valores trimestrais de alturas pluviométricas - Trimestre Primavera Fazenda São Bento

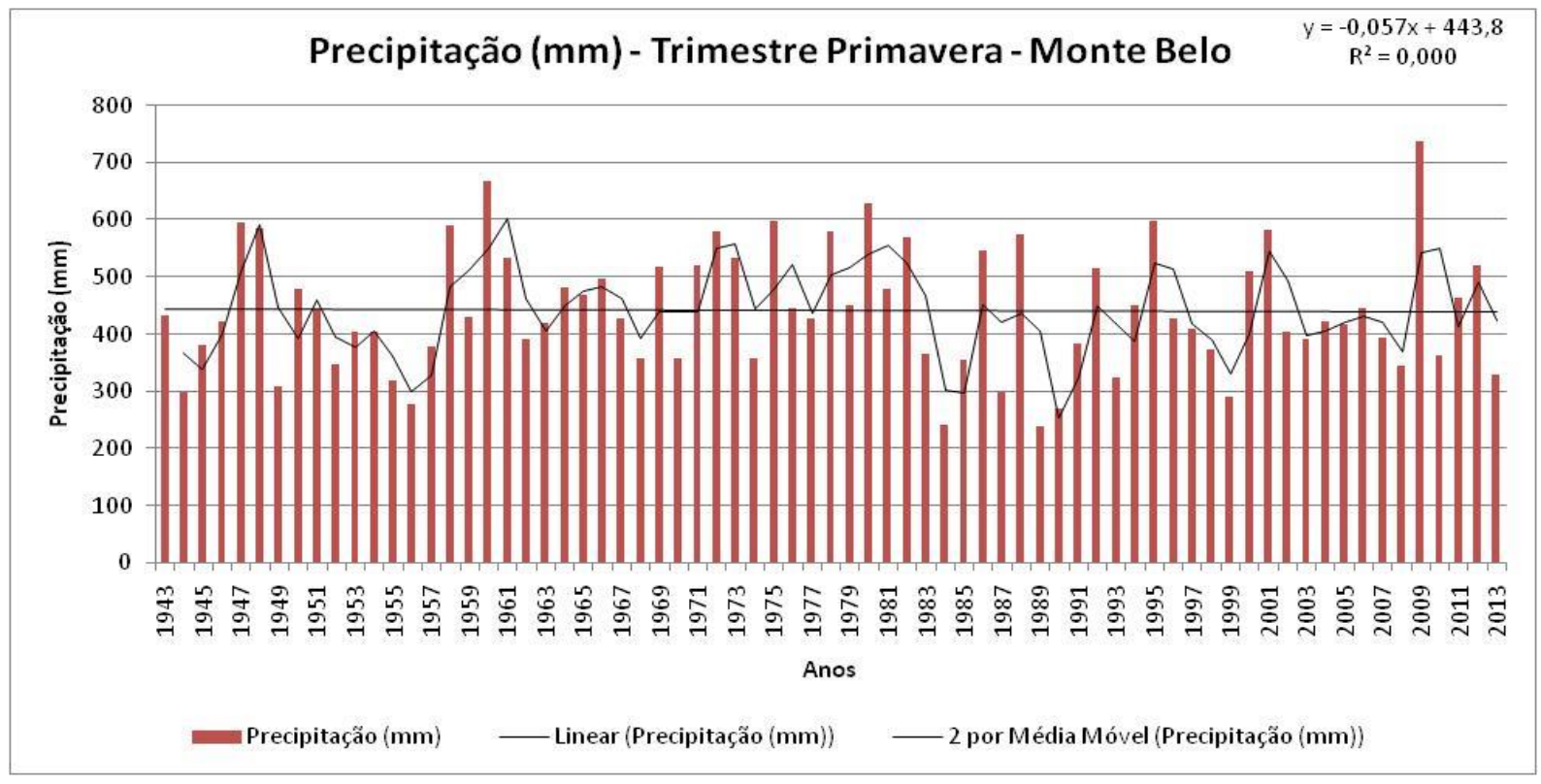

Gráfico 47: Valores trimestrais de alturas pluviométricas - Trimestre Primavera - Monte Belo 


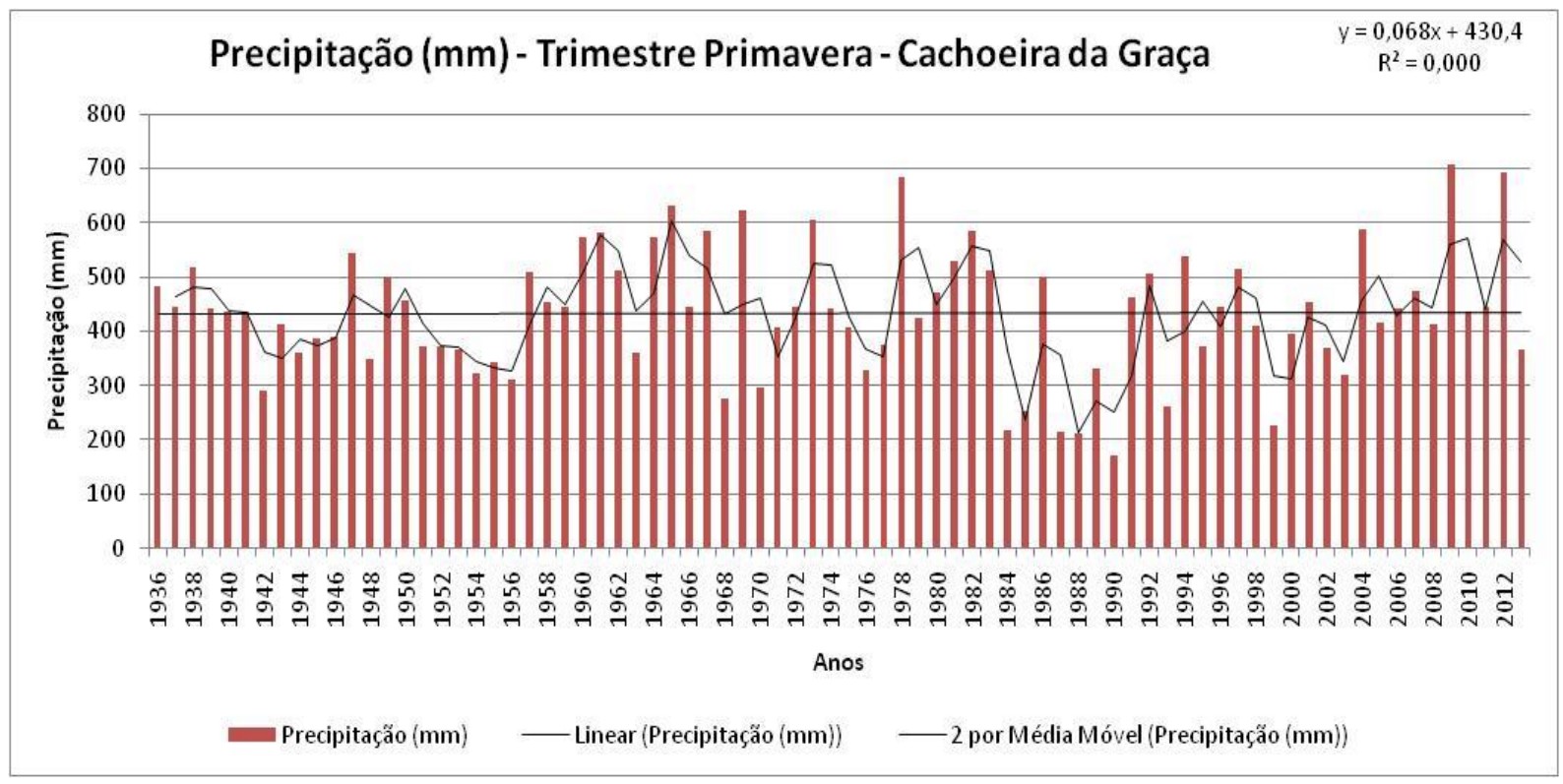

Gráfico 48: Valores trimestrais de alturas pluviométricas - Trimestre Primavera Cachoeira da Graça

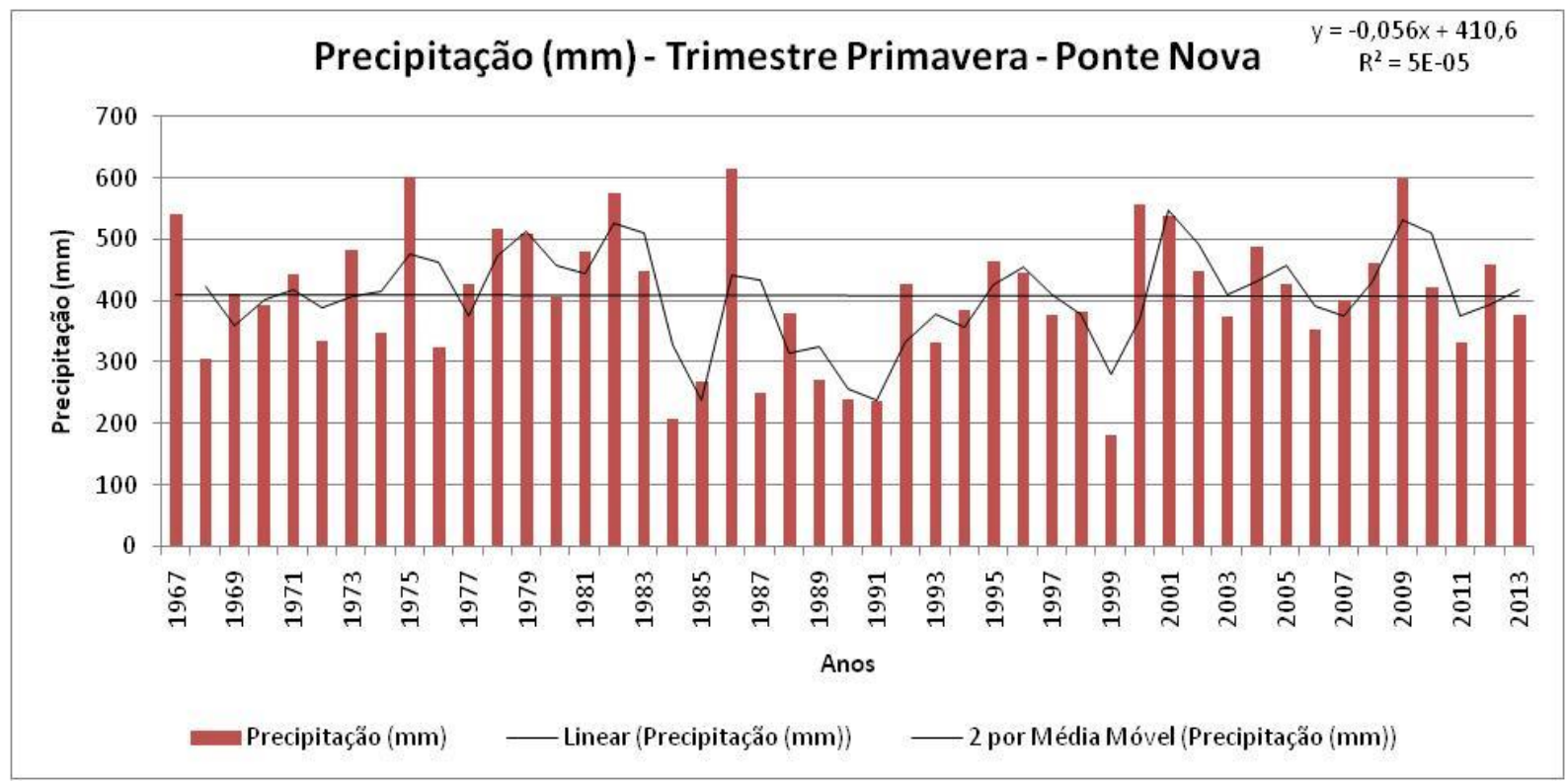

Gráfico 49: Valores trimestrais de alturas pluviométricas - Trimestre Primavera - Ponte Nova

De modo geral, o que se pode concluir dos dados e tendências analisadas, é que está ocorrendo uma elevação nos totais pluviométricos anuais e particularmente nos trimestres de verão e outono. 
É importante salientar que o trimestre de verão é responsável por quase $40 \%$ da precipitação total anual na RMSP, o que faz com que os valores apresentados sejam bastante influenciados por esse período.

Algumas séries, como a do IAG e Mirante de Santana, ambas localizadas em áreas densamente urbanizadas (Figura 18), apresentaram tendências positivas de aumento de precipitação em todos os trimestres analisados, enquanto os dados referentes ao posto pluviométrico Ponte Nova, que se localiza em uma área distante da mancha urbana, mostraram sempre tendências negativas ou nulas.

O parâmetro chuva apresenta uma forte correlação com o processo de urbanização, principalmente em relação aos episódios de chuvas fortes, que se acentuam a medida que as cidades crescem, fazendo com que diminuam as áreas verdes e aumente a impermeabilização do solo e as fontes de calor e poluição.

No entanto, esse parâmetro também apresenta um padrão de vinculação importante em termos regionais, e não somente urbanos, assim, é possível perceber que tem ocorrido um acréscimo nos totais pluviométricos em todo o estado de São Paulo, que de acordo com Sant'Anna Neto (1995) está vinculado principalmente aos "(...) ciclos de migração do anticiclone do Atlântico Sul, que quando associado aos eventos 'El Niño', provocam elevação significativa da pluviosidade no território paulista" (SANT'ANNA NETO, 1995, p.193)

De acordo com Nunes (1997), é possível afirmar que o estado de São Paulo tem apresentado como padrão dominante de alteração, tendências ao aumento dos índices de precipitação, que se verificaram em todo território paulista. A autora afirma ainda, concordando com San'Anna Neto (1995), que essa elevação está relacionada diretamente à atuação do fenômeno "El Niño". 
Outro ponto que deve ser considerado é a variabilidade espacial das chuvas na RMSP (Figura 20), sendo que a maior parte da área densamente urbanizada, localizada sobre planícies aluviais e terrenos levemente ondulados, apresenta totais de chuva entre $1300 \mathrm{~mm}$ a $1600 \mathrm{~mm}$.

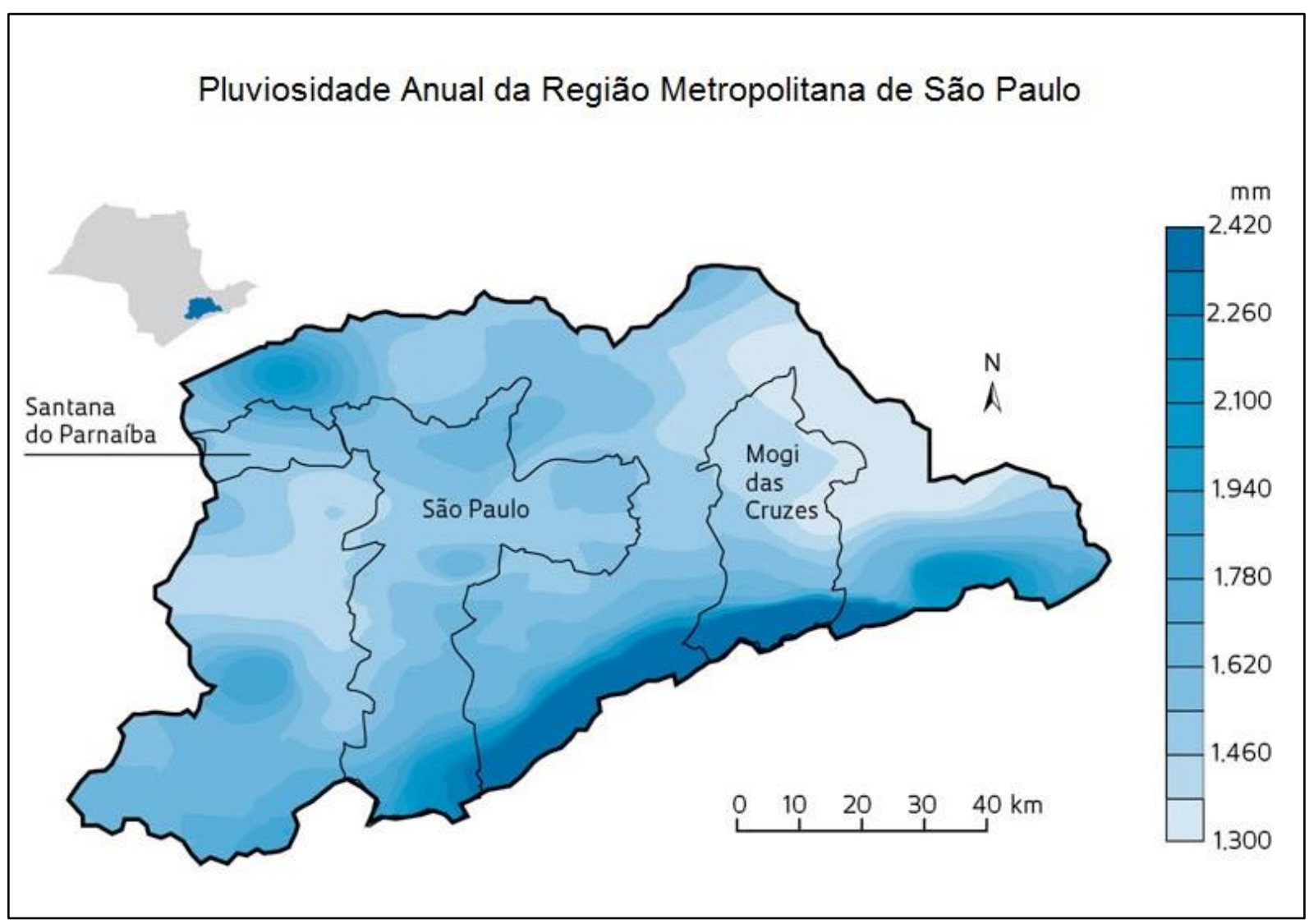

Figura 20: Pluviosidade anual na Região Metropolitana de São Paulo

Fonte: http://revistapesquisa.fapesp.br/2012/05/11/da-garoa-a-tempestade/ Acesso em $02 / 03 / 2015$

Adap. Lima, 2015

Esses totais vão aumentando gradativamente em direção a sudeste e sul da RMSP, onde se encontram valores de até $2400 \mathrm{~mm}$ anuais. Essas áreas se localizam em terrenos com maior declividade e amplitudes topográficas elevadas que envolvem parcialmente a bacia sedimentar de São Paulo. 


\subsubsection{Análise das séries de frequência de dias com precipitação acima de $20 \mathrm{~mm}$.}

Para verificar se além do aumento da pluviosidade total, está ocorrendo também um aumento do número de dias com chuvas mais intensas na RMSP, foram selecionadas três séries de registros (IAG, Mirante de Santana e Guarulhos) para análise da frequência de dias com precipitação a partir de 20 $\mathrm{mm}$.

Inicialmente foram avaliadas todas as séries de dados disponíveis e selecionadas àquelas que apresentaram o menor número de falhas durante o processo de correção, posteriormente, os dados foram separados por períodos que representassem uma fase inicial dos registros (urbanização insipiente), uma fase intermediária (quando possível) e os anos mais recentes. A série mais longa (IAG) foi divida em três períodos, e as demais (Mirante de Santana e Guarulhos) em dois.

Para cada período analisado foram gerados histogramas individuais e posteriormente sobrepostos para melhor visualização dos resultados. As classes estabelecidas levaram em consideração as precipitações máximas registradas em cada estação, tendo como o valor mínimo $20 \mathrm{~mm}$.

Os totais de precipitação diária de cada série de dados avaliada também foram representados em forma de gráfico (Apêndice 02), no qual é possível visualizar as três estações ao mesmo tempo ao longo dos anos de registros.

A série de dados da estação meteorológica do IAG (1933 a 2013) foi a mais representativa, por ser a mais longa e possibilitar a visualização do comportamento das chuvas em um período no qual a urbanização na RMSP ainda 
era bastante inicial. Os dados da estação Mirante de Santana (1961 a 2013) abarcam um período intermediário, no qual a RMSP apresentava um rápido crescimento das áreas urbanas que culminaria na metrópole como conhecemos hoje, enquanto os dados da estação Guarulhos (1983 a 2013) representam um período no qual a urbanização da metrópole, já bem estabelecida, passaria por pequenas mudanças de cunho estrutural e político, com a inclusão do tema na Constituição de 1988 e um crescimento mais lento da população.

O primeiro período analisado foi de 1933 a 1959 (Gráfico 50), momento histórico no qual o Brasil começava a se reestruturar após a crise econômica mundial e as grandes cidades iniciavam um processo de industrialização, que geraria um aumento populacional nesses centros e por consequência o crescimento urbano.

A RMSP ainda não havia sido criada oficialmente e a área urbana era muito menor que àquela que conhecemos hoje, com núcleos esparsos e bairros ainda em construção.

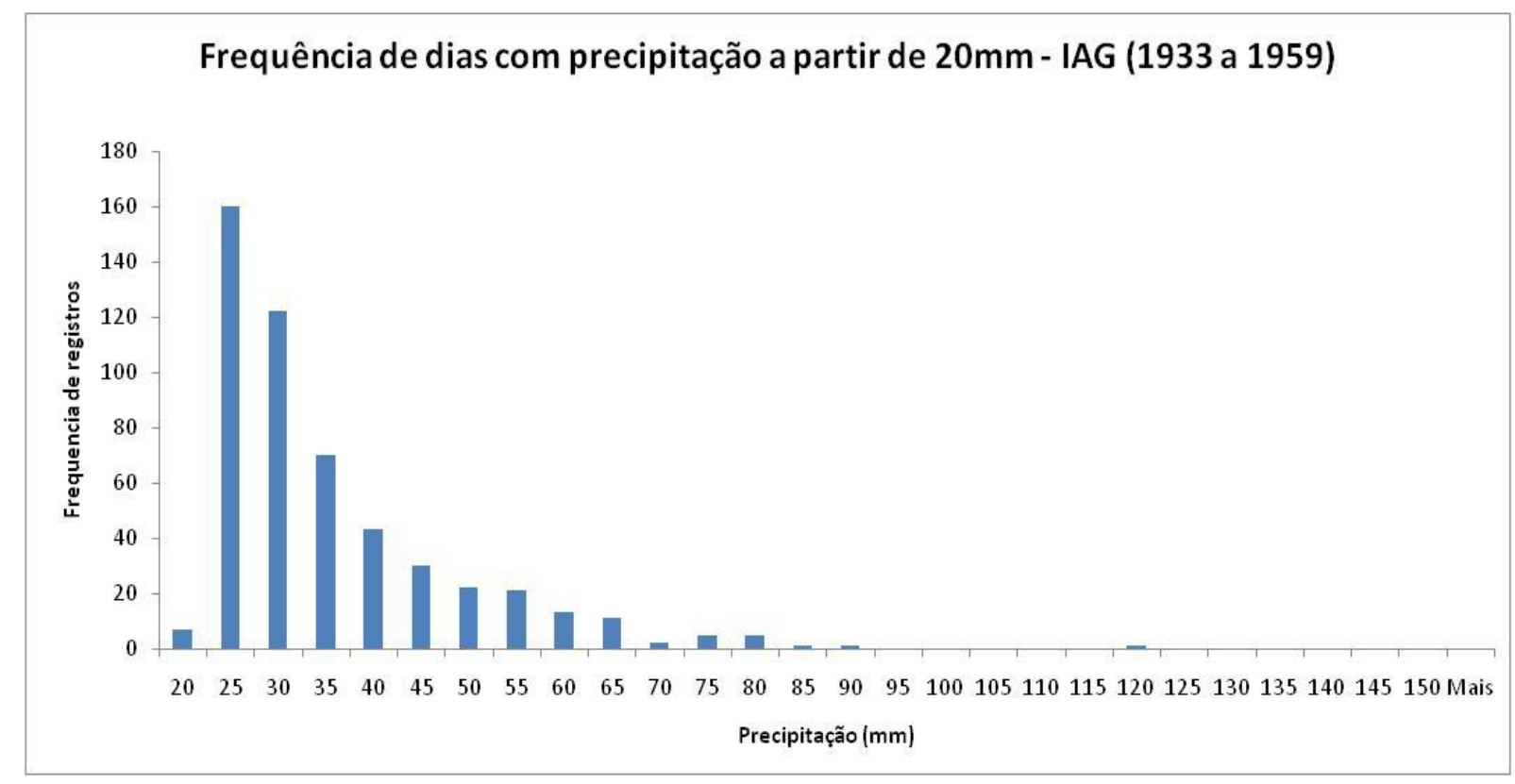

Gráfico 50: Frequência de dias com precipitação a partir de 20 mm - IAG (1933 a 1959) 
É possível perceber, pela análise do histograma, que as chuvas fortes mais frequentes nesse período eram de $25 \mathrm{~mm}$ a $30 \mathrm{~mm}$ em um dia, no entanto o número de registros desse fenômeno não era muito alto.

O segundo período analisado vai de 1960 a 1987 (IAG - 1960 a 1986 e Mirante de Santana - 1961 a 1987) (Gráficos 51 e 52), que foi um momento histórico de grande efervescência econômica e crescimento das áreas urbanas, principalmente nas grandes cidades. Com o fácil acesso a empréstimos internacionais, foram colocados em marcha os Planos Nacionais de Desenvolvimento, que refletiram na RMSP através de programas de construção de moradias populares financiadas pelo Banco Nacional de Habitação (BNH), que geraram a ocupação de áreas periféricas da mancha urbana já estabelecida e deram meios para um crescimento populacional e urbano muito rápido.

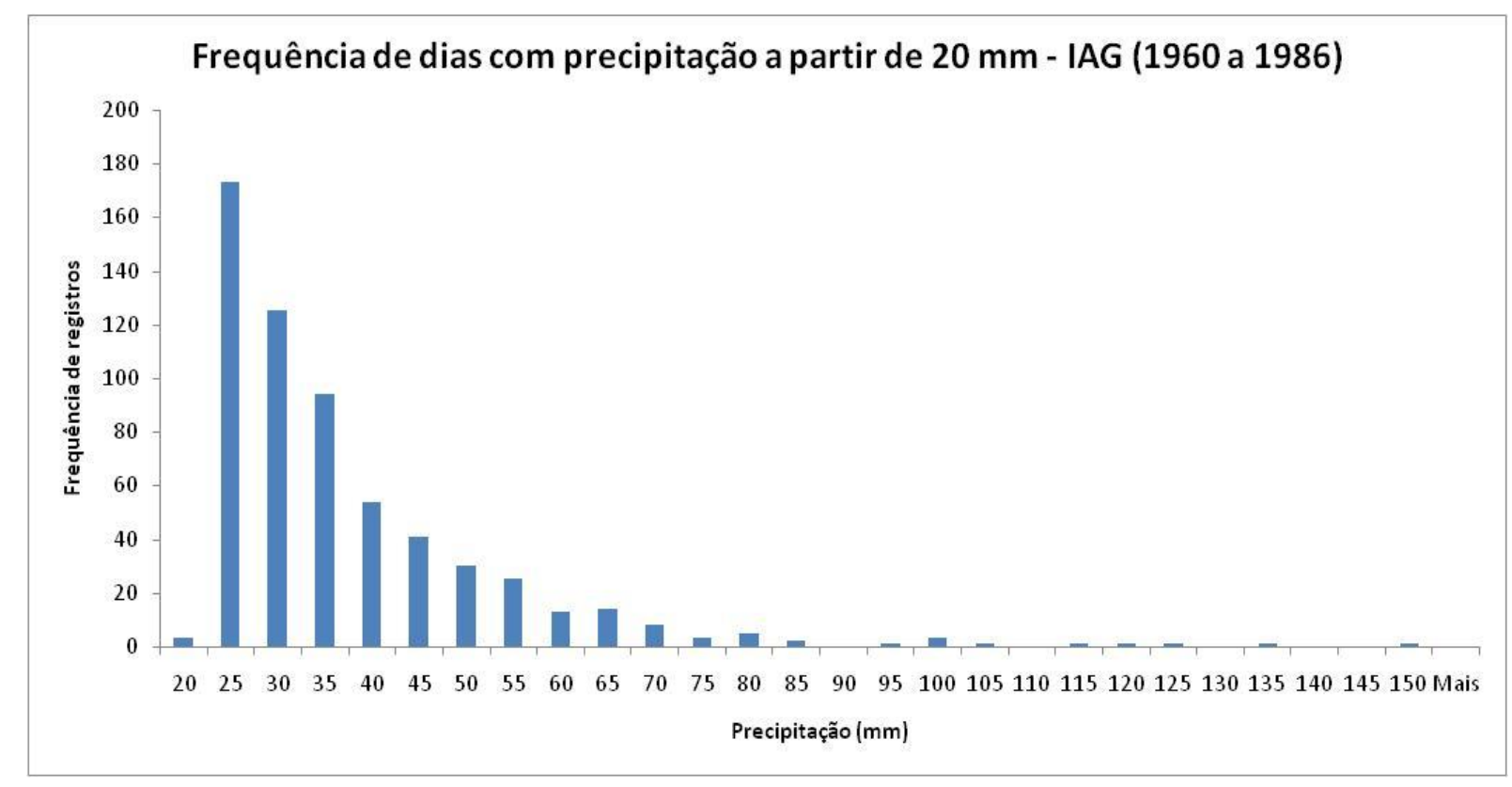

Gráfico 51: Frequência de dias com precipitação a partir de 20 mm - IAG (1960 a 1986) 


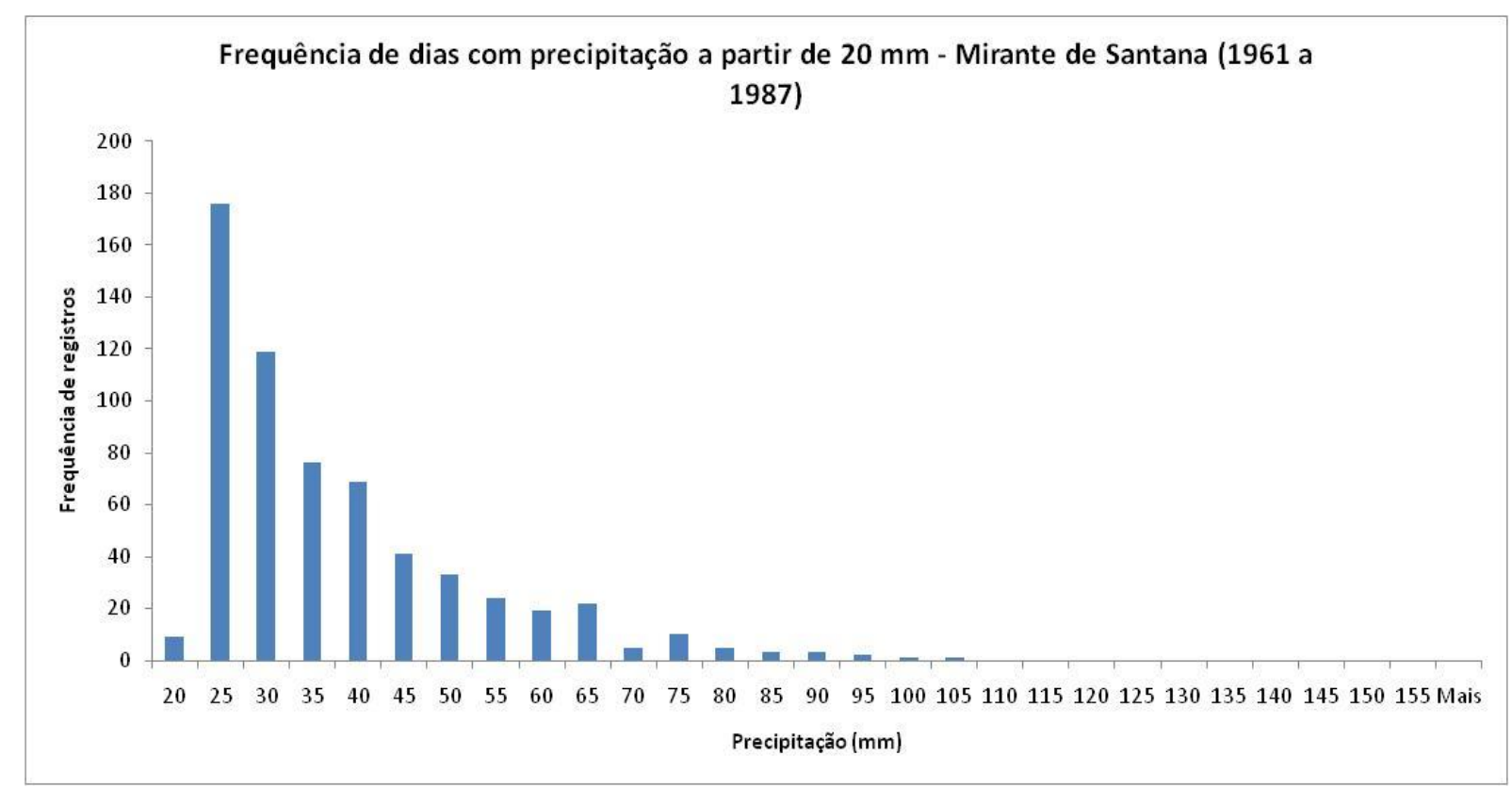

Gráfico 52: Frequência de dias com precipitação a partir de 20 mm - Mirante de Santana (1961 a 1987)

Nota-se que o número de registros de chuvas diárias entre $25 \mathrm{~mm}$ e $35 \mathrm{~mm}$ aumentou em relação ao período anterior e que também é perceptível a presença de eventos de precipitações muito intensas, a partir de $80 \mathrm{~mm}$ em um dia.

O período de 1987 a 2013 (IAG - 1987 a 2013, Mirante de Santana 1988 a 2013 e Guarulhos 1987 a 20135) (Gráficos 53, 54 e 55) se caracteriza por uma ampla mobilização popular em busca de cidades que atendessem melhor a população. Com a inserção do tema na Constituição de 1988, passou-se a se tratar da política urbana e da função social da propriedade, a partir daí os municípios brasileiros teriam que elaborar Planos Diretores e assegurar a participação popular em todas as decisões.

A taxa de crescimento populacional na RMSP (Tabela 01) vinha diminuindo gradativamente desde a década de 1970, no entanto, mesmo de forma mais

\footnotetext{
${ }^{5}$ Foram descartados os anos de 1983 a 1986 para que o intervalo de dados da estação Guarulhos pudesse ser comparado aos das outras estações.
} 
lenta, as áreas urbanas continuavam se expandindo. Na década de 1980 já existia uma periferia consolidada, e o que se tem observado nos anos mais recentes é o aumento da ocupação em áreas de risco nas bordas da mancha urbana.

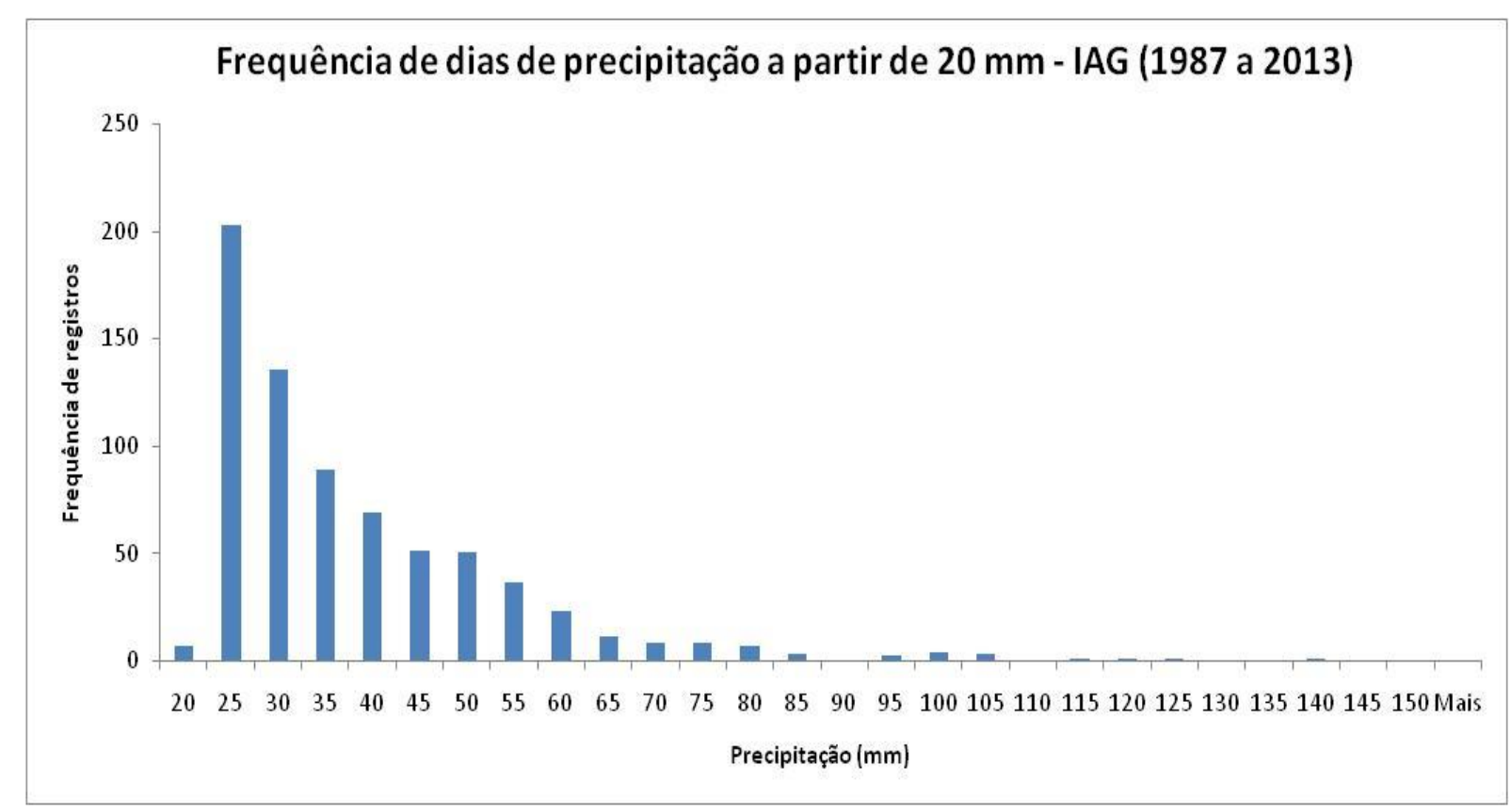

Gráfico 53: Frequência de dias com precipitação a partir de 20 mm - IAG (1987 a 2013)

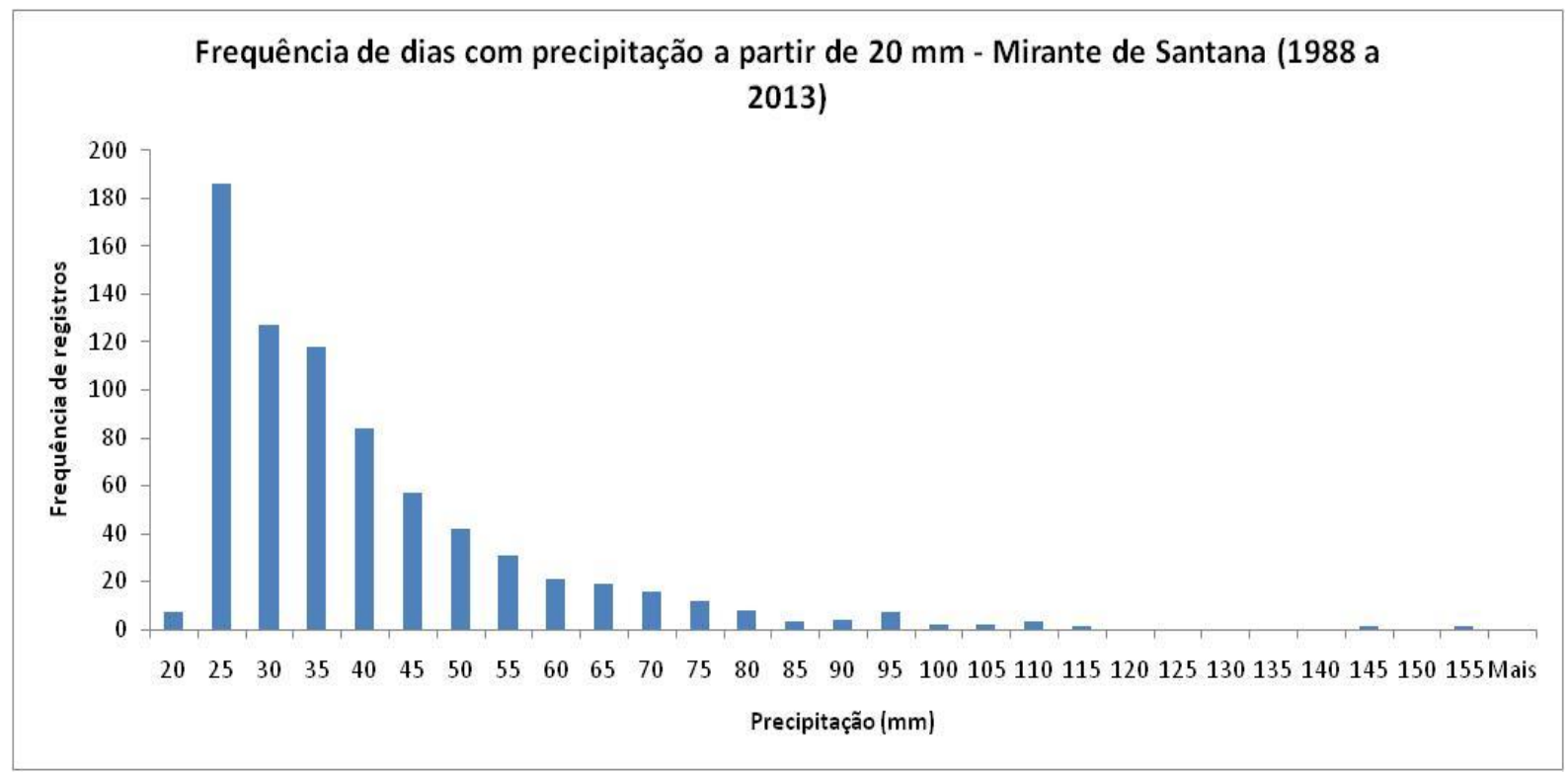

Gráfico 54: Frequência de dias com precipitação a partir de 20 mm - Mirante de Santana (1988 a 2013) 


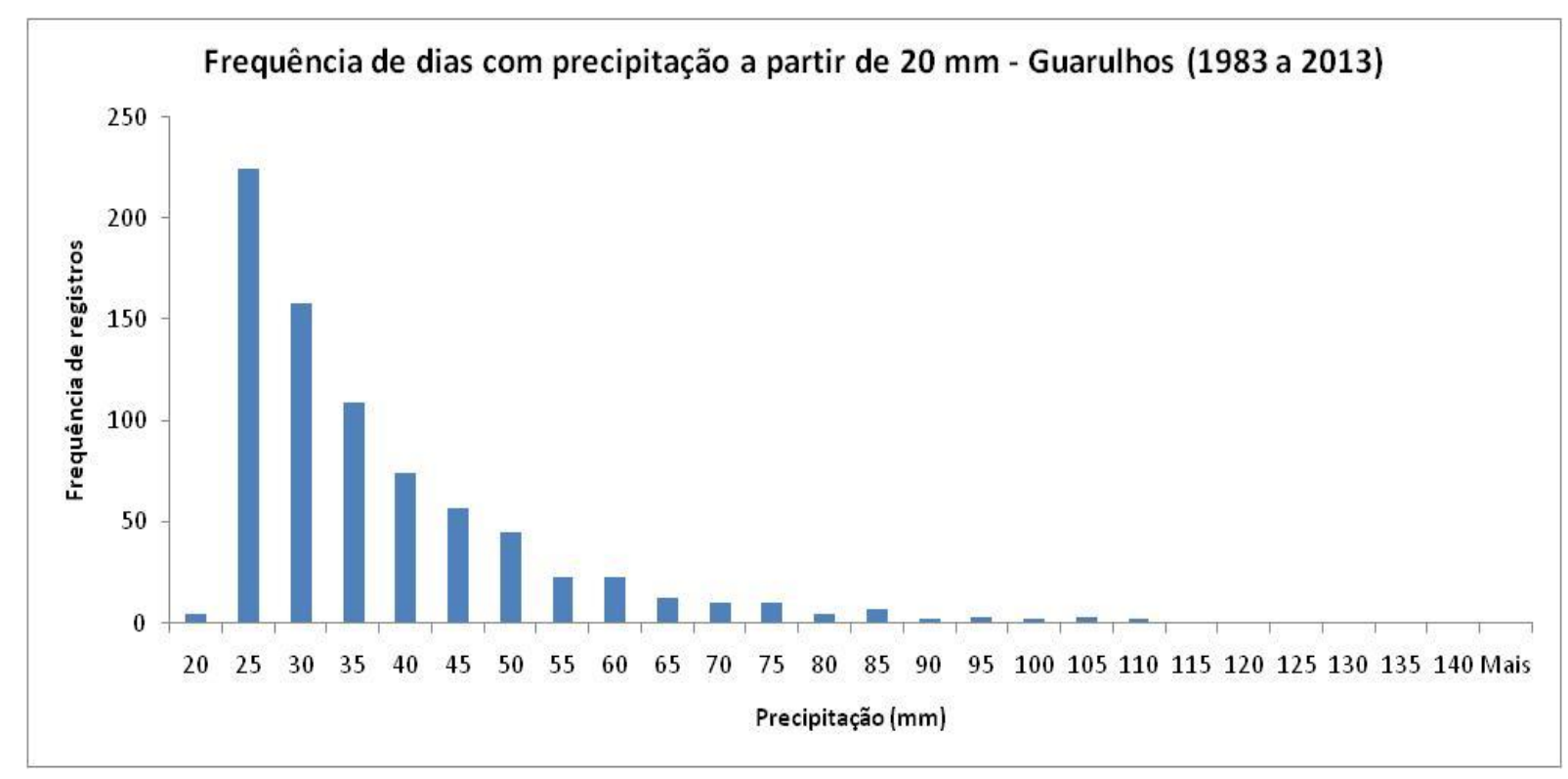

Gráfico 55: Frequência de dias com precipitação a partir de 20 mm - Guarulhos (1987 a 2013)

Mais uma vez, é possível perceber o aumento do número de registros de precipitações diárias entre $25 \mathrm{~mm}$ e $35 \mathrm{~mm}$ dentro de um intervalo de dados similar ao anteriormente analisado, o que demonstra que as precipitações mais intensas tem se tornado cada vez mais comuns. É possível realizar uma avaliação mais acurada através da análise dos histogramas comparados (Gráficos 56 e 57), nos quais se visualizam as diferenças no número de frequências de registros nos diferentes períodos. 


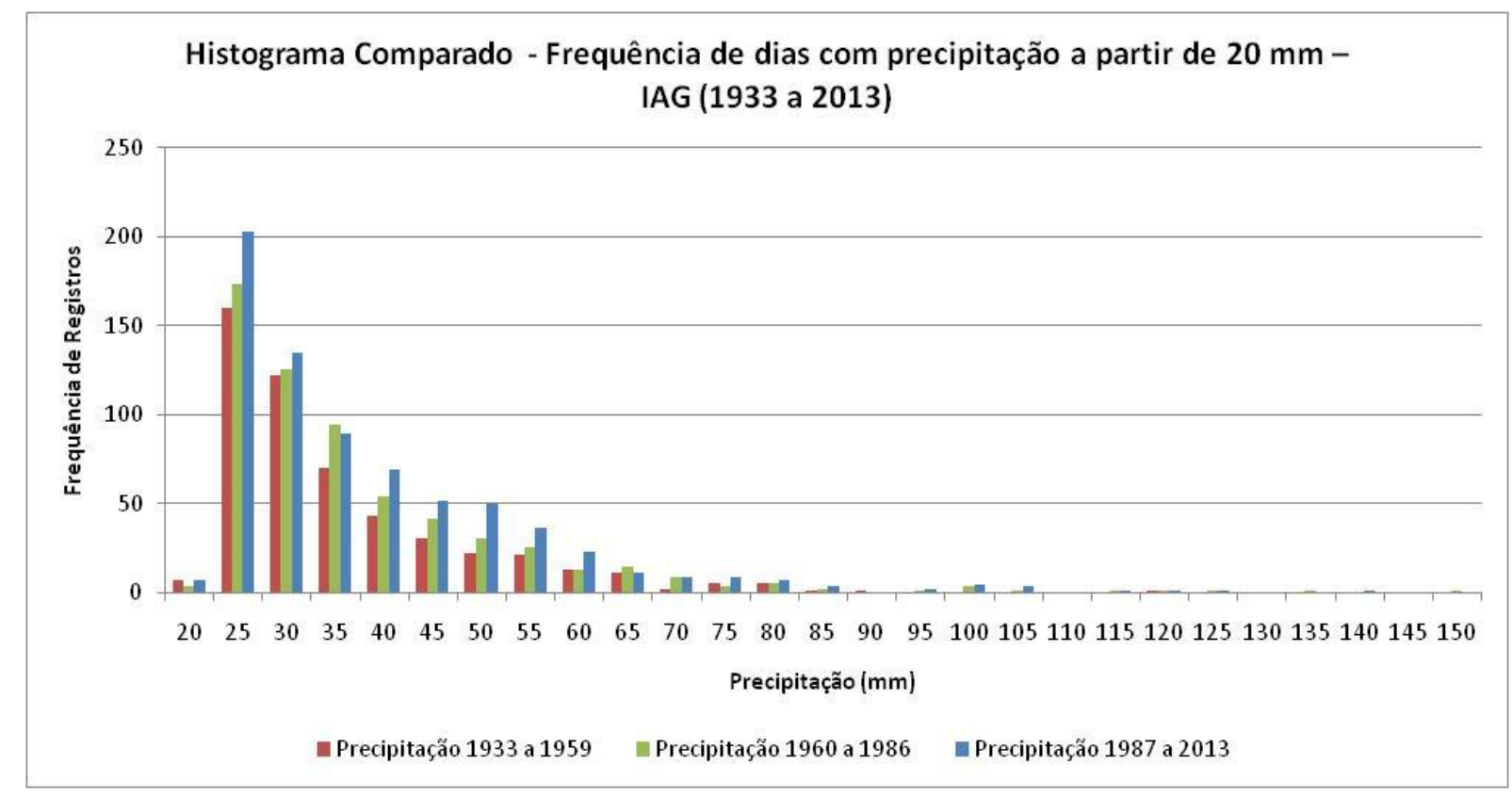

Gráfico 56: Histograma Comparado - Frequência de dias com precipitação a partir de 20 mm - IAG (1933 a 2013)

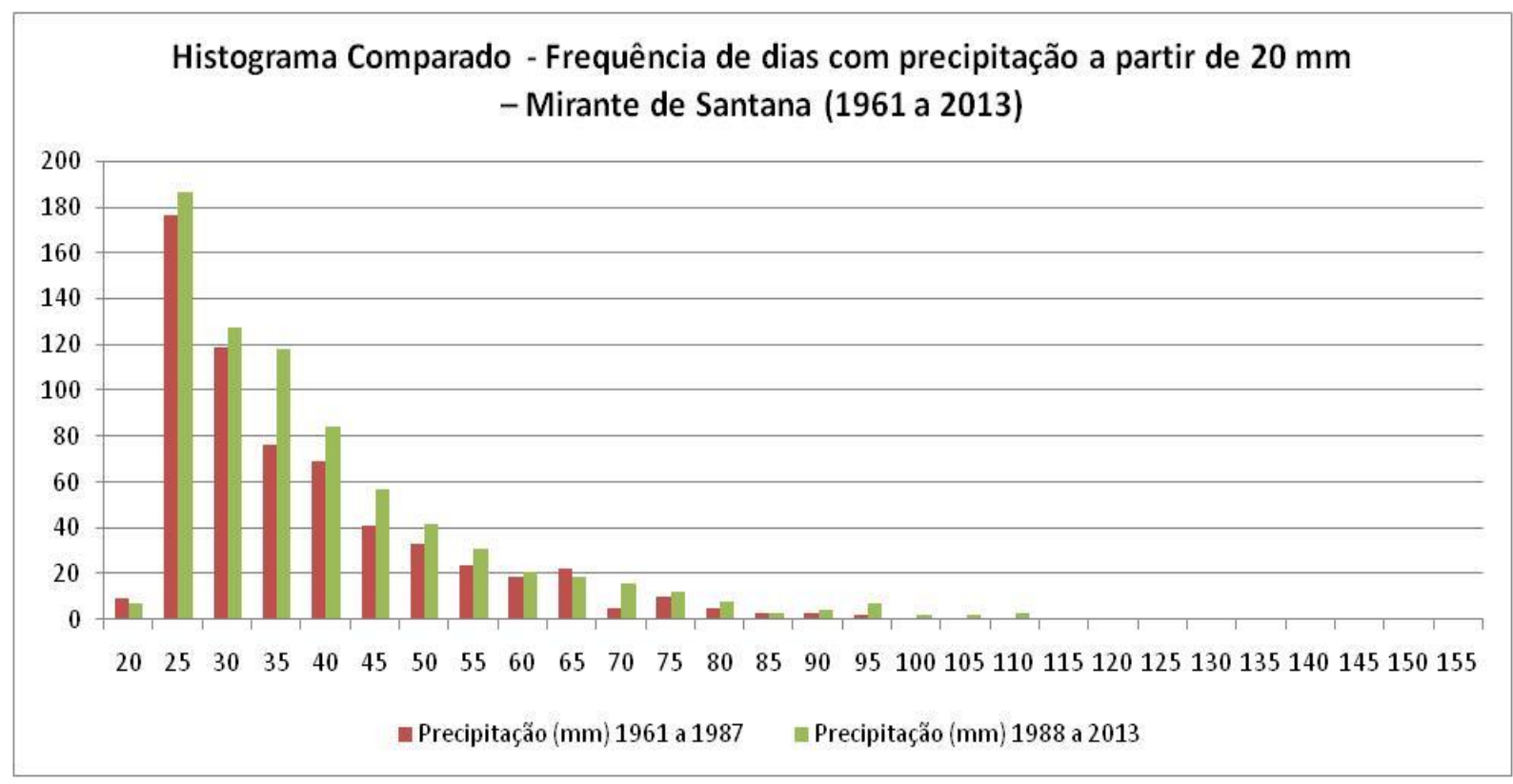

Gráfico 57: Histograma Comparado - Frequência de dias com precipitação a partir de 20 mm - Mirante de Santana (1961 a 2013)

O que é marcante em relação aos dados apresentados, em que pese a heterogeneidade dos períodos analisados, é que as séries apresentam valores expressivos de aumento de dias de precipitação mais intensa. Esse fato tem 
trazido como resultado, um aumento do número de eventos de chuva concentrada que vêm ocorrendo na RMSP nos últimos anos e um forte indício de associação com o processo de urbanização, já que este acentua o fenômeno ilha de calor, estimulando os movimentos convectivos e por consequência as instabilidades de tempo.

É interessante salientar que as estações meteorológicas aqui utilizadas sofreram um processo de incorporação à mancha urbana no decorrer dos anos, que fez com que os dados registrados fossem representativos dos diferentes momentos da urbanização na RMSP.

\subsection{Análise dos volumes de armazenamento dos mananciais da RMSP}

Para se realizar a análise dos volumes de armazenamento dos mananciais que abastecem a Região Metropolitana de São Paulo foram utilizados os dados fornecidos diariamente pela SABESP (Companhia de Saneamento Básico do Estado de São Paulo) em seu site $^{6}$, com registros disponíveis a partir do ano de 2003.

O ideal para esta análise seria uma série de dados mais longa, com a qual fosse possível estabelecer relações precisas entre a precipitação e o volume de água disponível nos reservatórios para o abastecimento público, no entanto, os vários contatos realizados com funcionários e administradores da SABESP foram infrutíferos, e os dados solicitados foram negados (Anexo), assim, optouse por trabalhar com os registros de acesso público.

O abastecimento de água na RMSP é realizado pelo Sistema Adutor Metropolitano (SAM), que é a interligação de todos os Sistemas Produtores de

\footnotetext{
${ }^{6}$ SABESP: http://www2.sabesp.com.br/mananciais/DivulgacaoSiteSabesp.aspx
} 
Água, nos quais são utilizados basicamente mananciais de superfície (Cantareira, Alto Tietê, Guarapiranga, Alto Cotia, Rio Grande e Rio Claro).

Os volumes de água armazenados nos reservatórios são controlados diariamente por medições, e os valores divulgados se referem ao total armazenado no "Volume Útil", que é àquele que pode ser utilizado sem a necessidade de bombeamento, mais a "Reserva Técnica", volume estocado no reservatório que só pode ser utilizado com o auxílio de bombeamento.

Os dados coletados no site da SABESP foram digitados em forma de planilha e posteriormente calculados, para que fosse possível obter as médias dos volumes anuais e sazonais armazenados. Os gráficos gerados foram comparados aos dados de precipitação e analisados segundo cada período.

Optou-se por acrescentar um segundo eixo de ordenadas em cada gráfico com os dados de precipitação anuais e sazonais da Estação Meteorológica do IAG (2003 a 2013) com o objetivo de facilitar a comparação. A escolha dessa série se deu por ser a que menos apresentou falhas durante o processo de correção e pela posição geográfica da Estação, que se localiza na faixa com precipitações médias anuais variando entre 1300 mm e 1700 mm, que representa a maior parte da RMSP.

Inicialmente foram analisados os valores sazonais dos volumes de armazenamento dos mananciais. O trimestre de verão (Gráfico 58), comumente o mais chuvoso na região, apresentou períodos de volumes bastante baixos em detrimento dos totais de chuva precipitados. Em especial nos reservatórios da Cantareira e do Alto Tietê, que apresentaram grandes oscilações ao longo dos anos. 


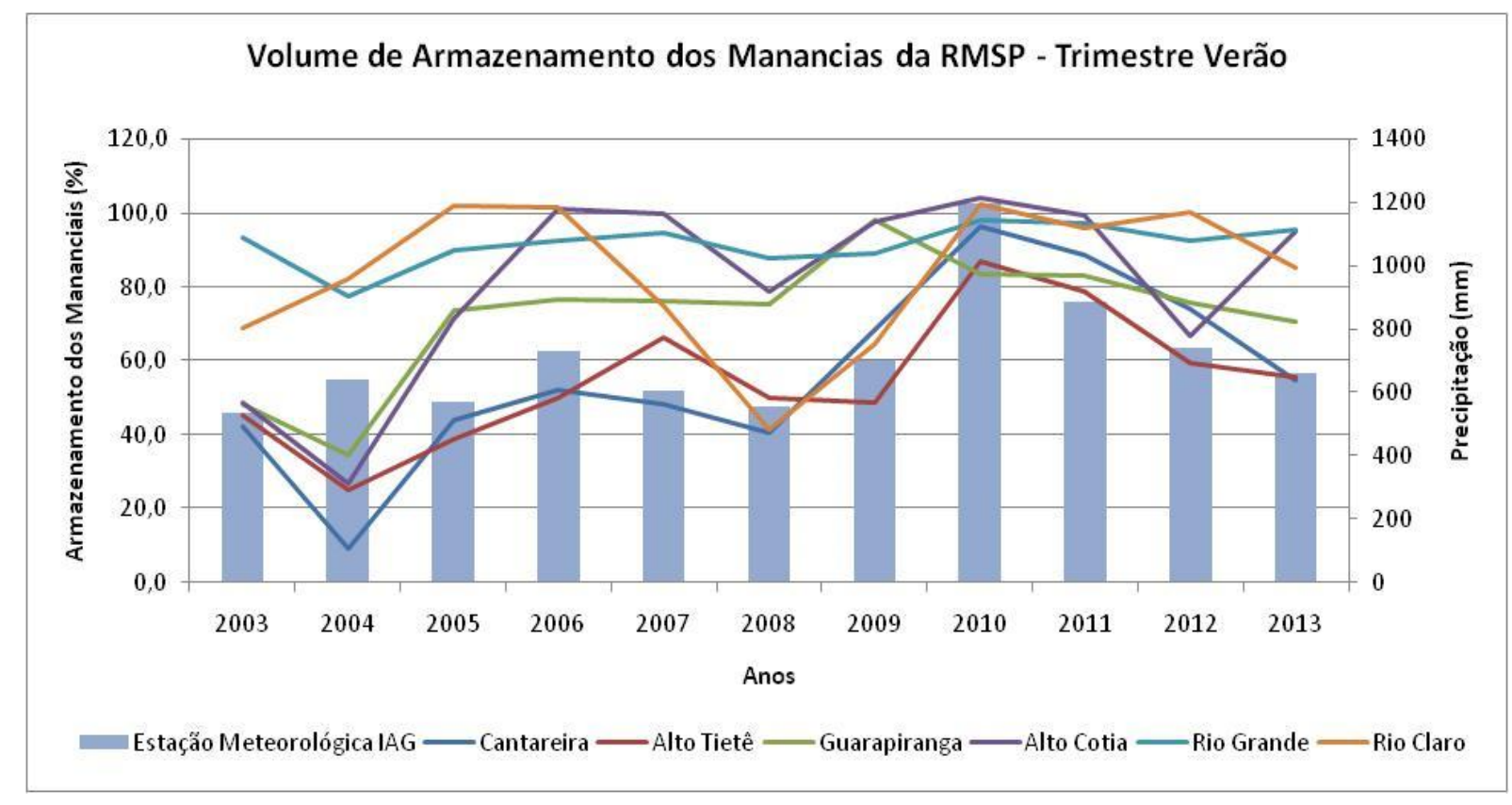

Gráfico 58: Volume de armazenamento dos mananciais da RMSP - Trimestre de Verão

Destaque especial é dado ao verão de 2004, no qual os totais de chuva ultrapassaram os $600 \mathrm{~mm}$, enquanto os volumes armazenados nos reservatórios da Cantareira, Alto Tietê, Alto Cotia e Guarapiranga não atingiram nem $40 \%$ de suas capacidades. O caso mais grave é o da Cantareira, que nesse período registrou médias de $9,2 \%$ de armazenamento, com alguns dias apresentando valores abaixo dos $4 \%$.

Em partes, esses baixos índices tiveram origem no ano de 2003, que apresentou chuvas um pouco abaixo das médias, no entanto, os valores voltaram a se normalizar durante o ano 2004, mas os volumes de armazenamento não apresentaram aumento considerável.

Outro fator importante é que neste mesmo período os reservatórios dos Sistemas Rio Grande e Rio Claro permaneceram com volumes altos de armazenamento (acima dos 70\%), o que indica que não foi somente a diminuição das chuvas no ano de 2003 que ocasionou a queda nos volumes armazenados. 
Durante o trimestre de outono (Gráfico 59) os volumes de armazenamento dos reservatórios da RMSP apresentaram um ligeiro aumento, decorrente do acumulado de chuvas do verão. Novamente o ano de 2004 se destaca, pois os mananciais da Cantareira, Alto Tietê, Guarapiranga e Alto Cotia permaneceram com volumes médios baixos, pouco maiores que os registrados no trimestre anterior.

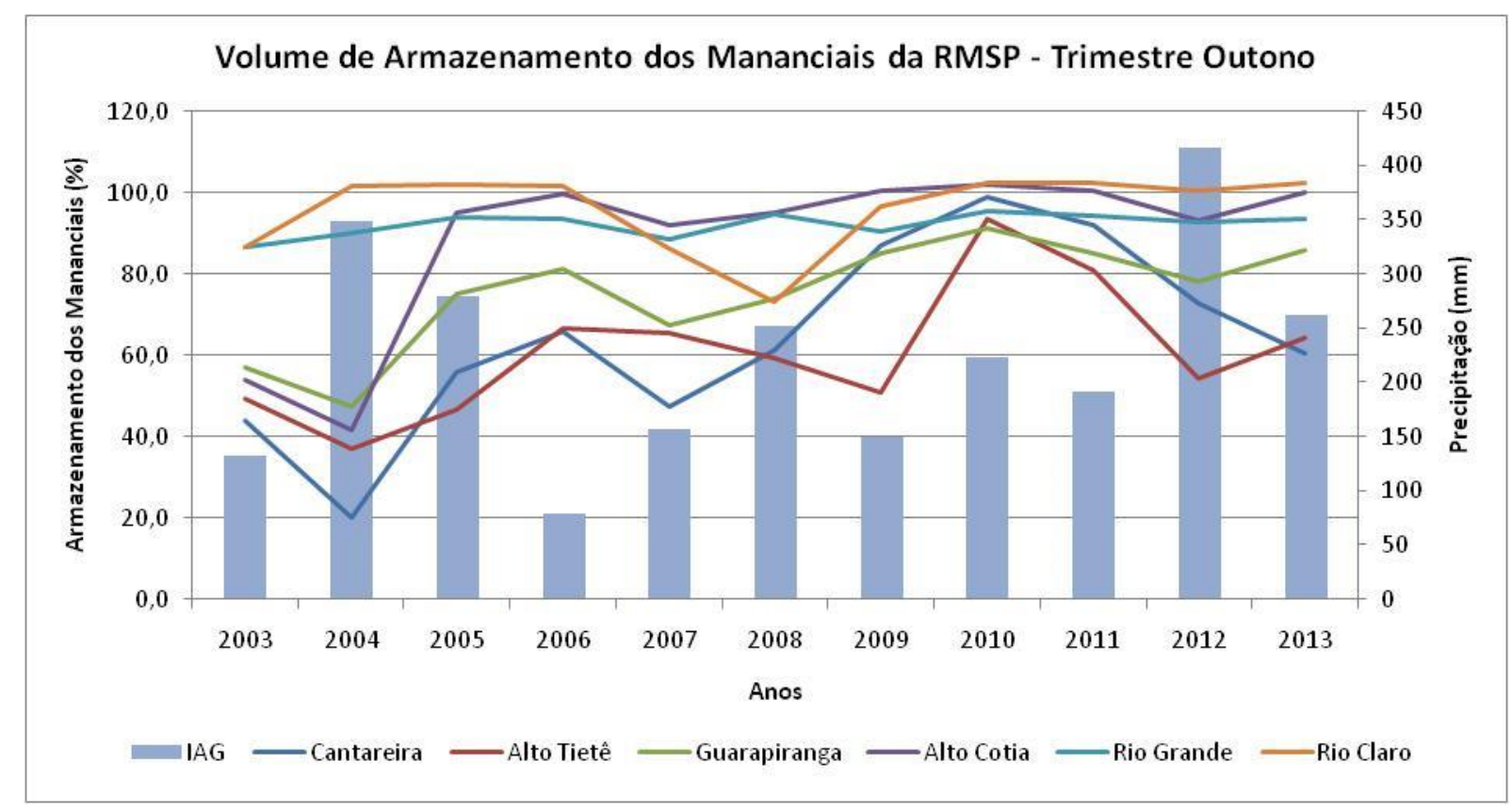

Gráfico 59: Volume de armazenamento dos mananciais da RMSP - Trimestre de Outono

O ano de 2012 também chama atenção, pois, mesmo com uma precipitação acumulada de mais de 1000 mm nos trimestres de verão e outono, que equivalem a aproximadamente $70 \%$ do total previsto de chuvas anuais, o reservatório do Sistema Alto Tietê apresentou um volume médio de armazenamento de pouco mais de $50 \%$ de sua capacidade total.

No trimestre de inverno (Gráfico 60), com a diminuição das chuvas, os totais de armazenamento de todos os reservatórios caem um pouco, mas é 
interessante perceber que os volumes registrados no Sistema Rio Grande oscilam menos, se mantendo sempre próximos a sua capacidade máxima.

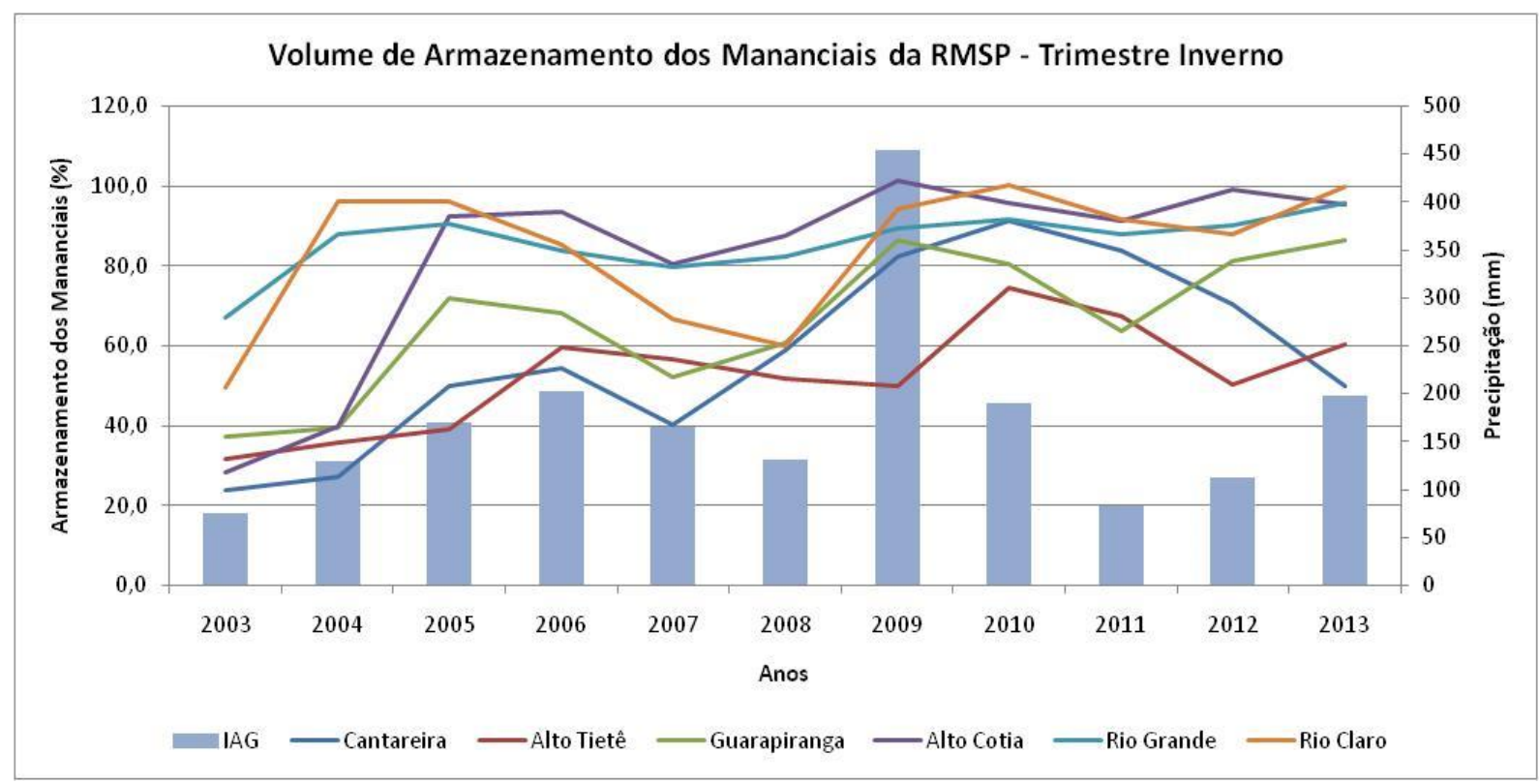

Gráfico 60: Volume de armazenamento dos mananciais da RMSP - Trimestre de Inverno

Os Sistemas Cantareira e Alto Tietê são os mais instáveis, sofrendo quedas nos volumes armazenados de maneira rápida, mesmo quando os totais de chuva permanecem dentro das médias normais para o período.

Durante a primavera (Gráfico 61), os totais de precipitação aumentaram um pouco em relação ao inverno, e por consequência os volumes armazenados nos reservatórios.

Enquanto o reservatório do Sistema Rio Grande não apresentou em nenhum momento volumes médios abaixo dos $60 \%$ de sua capacidade, os Sistemas Cantareira, Alto Tietê, Guarapiranga e Alto Cotia apresentaram volumes que oscilaram rapidamente, chegando a valores críticos, como por exemplo 4,8\% (Cantareira 2003) e 7,9\% (Alto Cotia 2003). 


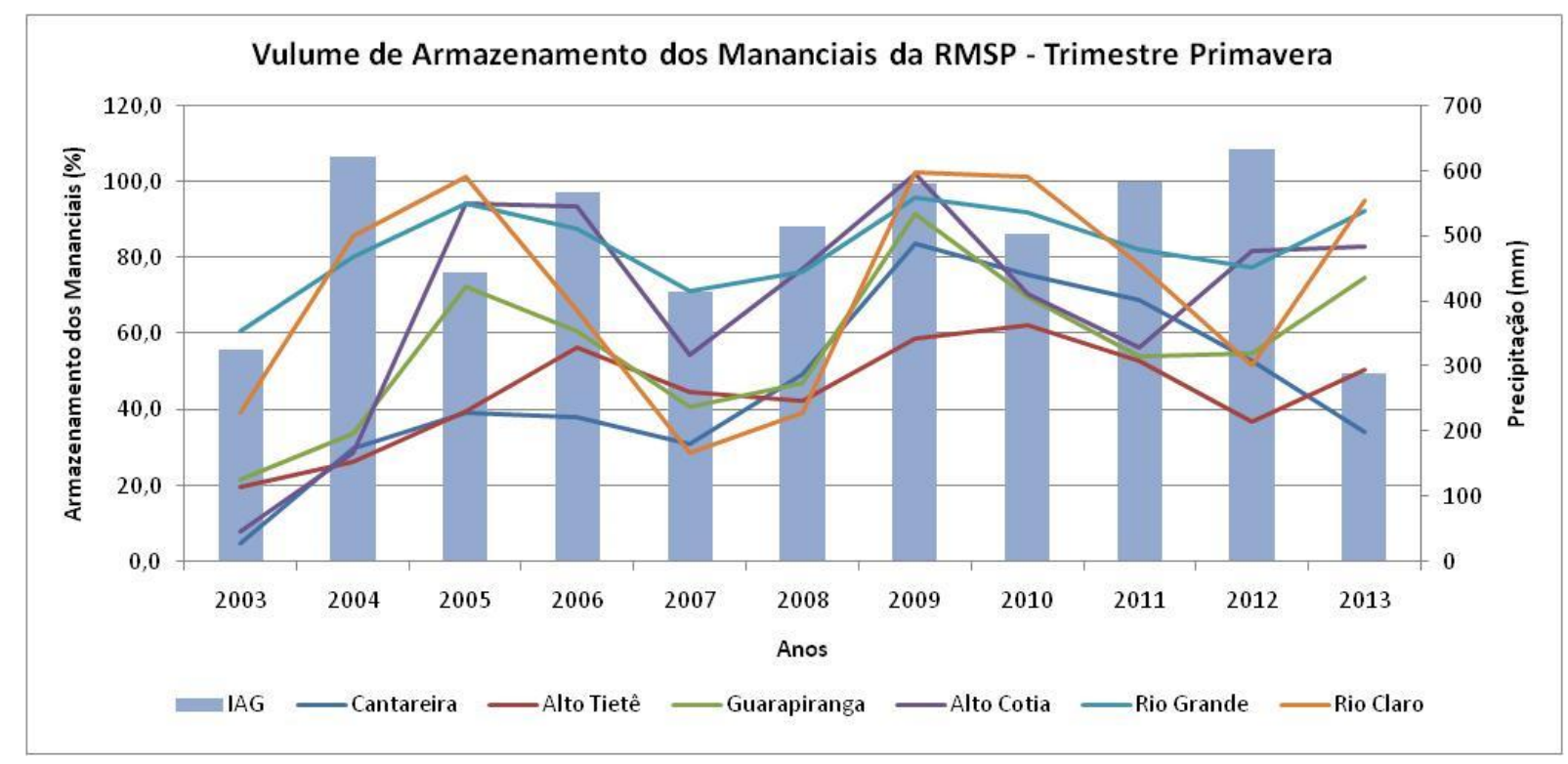

Gráfico 61: Volume de armazenamento dos mananciais da RMSP - Trimestre de Primavera

Observando-se o gráfico com os valores médios de armazenamento anuais (Gráfico 62), é possível ter uma visão mais ampla do comportamento de cada reservatório.

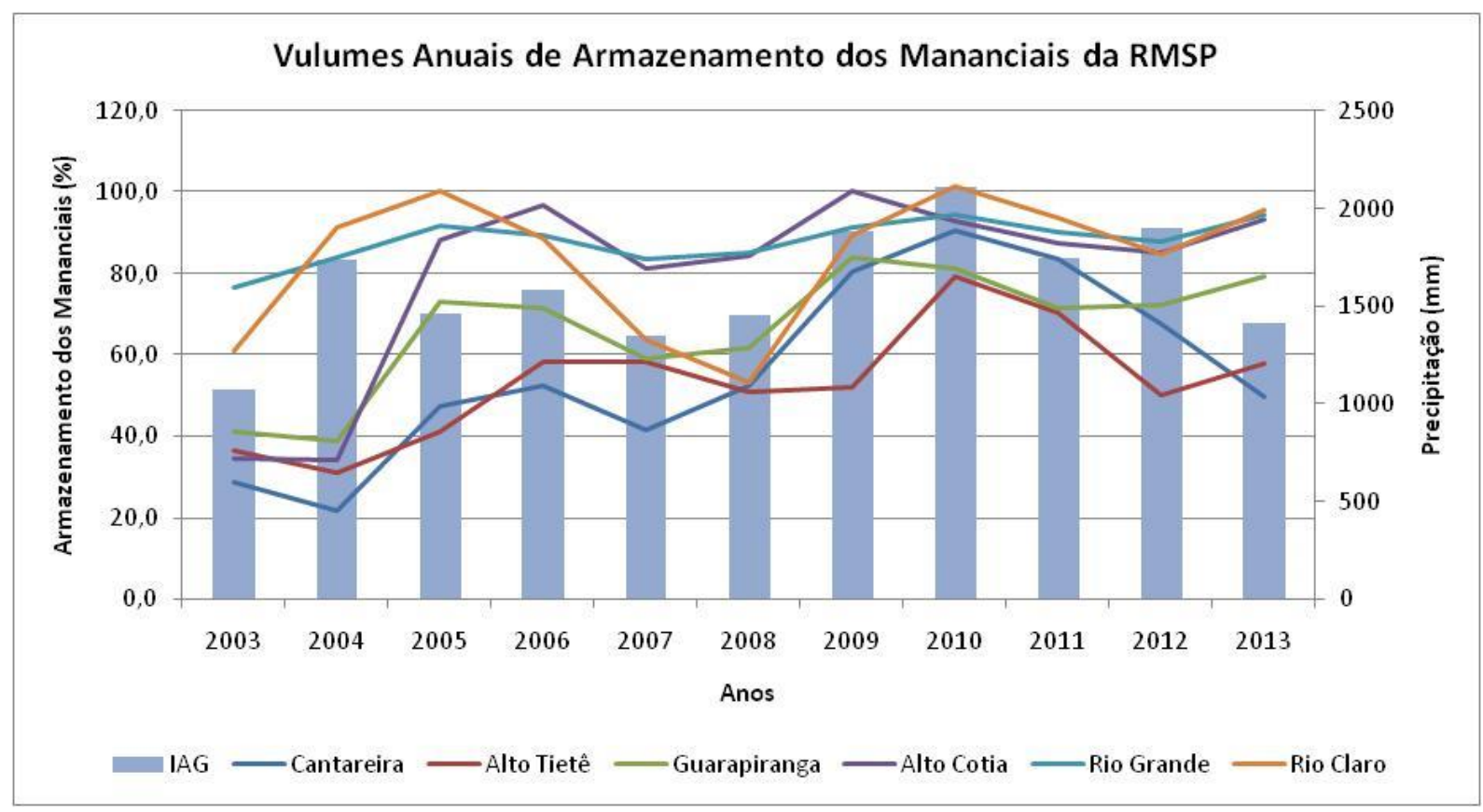

Gráfico 62: Volumes anuais de armazenamento dos mananciais da RMSP 
Sob condições climáticas semelhantes, as taxas de armazenamento de cada manancial são bastante diferentes, o que sugere que os totais de chuva precipitados não são o único fator causador dos problemas de abastecimento da RMSP, e os exemplos mais marcantes são os Sistemas Cantareira e Alto Tietê em comparação com o Sistema Rio Grande.

Muitas vezes o poder público e a mídia atribuem os problemas de escassez hídrica para população à diminuição das chuvas em determinados anos, mas a análise dos dados referentes aos totais de precipitação e aos volumes de armazenamento dos mananciais indica que essa não é uma questão tão simples, e que certamente envolve muitos outros fatores, tais como a falta de investimentos em obras de melhoria dos sistemas de abastecimento, perda vegetal no entorno dos reservatórios decorrente da expansão urbana, entre outros. 


\section{Considerações Finais}

De uma maneira geral, o que se pode concluir a partir dos resultados dessa pesquisa é que eles apontam no sentido de que existem indícios de efeitos da urbanização sobre os extremos climáticos e o comportamento das chuvas na RMSP, tais como uma tendência a elevação dos totais pluviométricos sazonais e anuais e o aumento da ocorrência de episódios com chuvas mais intensas (acima de $20 \mathrm{~mm}$ ), registradas principalmente em estações localizadas em áreas densamente urbanizadas.

As tendências de aumento das precipitações, anuais e sazonais, encontradas em boa parte das séries analisadas nesta pesquisa, indicam que exista uma causalidade relacionada com os altos índices de poluição atmosférica registrados nas grandes metrópoles, a intensificação da ilha de calor e o efeito da rugosidade decorrente do processo de verticalização.

Além da influência das áreas urbanas sobre o clima, fenômenos de escala regional e global, como as ocorrências do fenômeno "El Niño" e as variações na temperatura superficial do oceano Atlântico, também contribuem para gerar tendências positivas de aumento nos totais de precipitação.

A técnica estatística utilizada (análise de séries temporais) mostrou-se adequada em relação aos objetivos propostos, mesmo considerando-se os problemas encontrados nas séries de dados e a grande variabilidade temporal de cada uma.

Através da análise dos gráficos referentes ao armazenamento dos mananciais, nota-se que as médias dos volumes armazenados nos reservatórios que abastecem a RMSP não apresentaram um comportamento padrão, pois, mesmo em condições climáticas semelhantes, alguns reservatórios possuíam um 
elevado volume de água armazenado, enquanto outros oscilavam rapidamente, sendo registrados, muitas vezes, valores bem abaixo de sua capacidade.

Os casos mais emblemáticos são os dos Sistemas Cantareira e Alto Tietê, que em alguns momentos chegaram a apresentar volumes baixíssimos, menores que $10 \%$ de sua capacidade total.

Os problemas apresentados por esses dois sistemas não é algo atual, de acordo com a Agência Nacional de Águas, a autorização para a utilização de $33 \mathrm{~m}^{3} / \mathrm{s}$ do Sistema Cantareira foi dado à SABESP no ano de 1974 , e esse acordo foi renovado em 2004 devido à enorme dependência da RMSP em relação a esse Sistema, que nesse momento atendia o equivalente a $50 \%$ da população.

A outorga dada à SABESP para utilização das águas do Sistema Cantareira terminaria em 2014, no entanto, devido à excepcional baixa na disponibilidade hídrica do Sistema nesse ano, que levou a utilização de sua Reserva Técnica, foi prorrogada até outubro de 2015.

O Sistema Alto Tietê, que entrou em funcionamento em 1992 com a função de resolver os graves problemas de abastecimento da região Leste da RMSP atualmente está com seu reservatório em situação crítica, pois desde sua inauguração não recebeu grandes investimentos em melhorias.

Ao contrário do que tem ocorrido com os Sistemas Cantareira e Alto Tietê, o reservatório do Sistema Rio Grande apresentou-se durante toda a análise com volumes armazenados elevados, mesmo em anos com precipitações abaixo das médias, o que indica que os totais pluviométricos não são os únicos fatores causadores dos problemas de abastecimento na RMSP.

Considerando que a análise dos dados de precipitação aqui realizada demonstra uma tendência positiva de aumento nos totais de chuva, esse não seria um problema a ser considerado para o futuro, no entanto, as chuvas 
concentradas e mais intensas não são tão benéficas para a recarga dos mananciais, pois a infiltração que leva água aos lençóis subterrâneos (elemento importante para recarga dos mananciais) é um processo lento, que ocorre mais facilmente durante episódios de chuvas constantes e menos intensas, além do fato dos eventos extremos de precipitação serem muitas vezes causadores de danos aos sistemas, comprometendo barragens e tubulações.

Seria necessária uma adaptação aos novos padrões de chuvas identificados (tendências positivas de aumento de precipitação e chuvas intensas concentradas em períodos mais curtos), para que fosse possível a manutenção do abastecimento hídrico para população nos próximos anos. A questão é: De que maneira se poderia aproveitar essa mudança no comportamento das chuvas em um contexto onde o grau de pressão sobre os recursos hídricos só tem aumentado?

Algumas sugestões podem ser propostas:

- Planejar o manejo adequado das bacias hidrográficas e dos aquíferos, para que as chuvas intensas sejam benéficas ao invés de causadoras de problemas;

- Promover o desenvolvimento administrativo e técnico dos setores responsáveis pelo abastecimento de água na RMSP;

- Incluir o uso da informação climática e aplicação de sistemas de alerta no planejamento de novos Sistemas Produtores e na reestruturação dos já existentes;

-Gestão integrada de bacias hidrográficas, a fim de recuperar aquíferos, cuidar das zonas de recarga, promover projetos para produção de água e limpar cursos de água superficiais;

- Ampliar o tratamento e uso de águas residuais e reduzir o consumo. 
No entanto, para que haja proteção, manutenção e preservação dos recursos hídricos disponíveis é imprescindível que sejam criadas leis adequadas e mais rigorosas, que norteiem e disciplinem o uso da água e a ocupação do entorno das áreas onde se localizam os mananciais.

Do ponto de vista legal, já existe há algum tempo leis que ditam condições para o aproveitamento adequado dos mananciais para fins de abastecimento público e o disciplinamento do uso do solo para proteção dos recursos hídricos, como a lei no 1.172/1976, o decreto no 9.714/1977 e a lei no 9.866/1997, no entanto, o que se observa é o crescimento constante da mancha urbana da RMSP em direção às áreas de proteção e o descumprimento dessas normas até mesmo pelo poder público.

A ocupação irregular de áreas de proteção afeta drasticamente a qualidade da água e incide diretamente na disponibilidade de uso desse recurso para abastecer uma população que cresce constantemente.

A perda por contaminação ou por questões técnicas de qualquer um dos mananciais superficiais hoje utilizados para o abastecimento da RMSP implicaria em transtornos irreparáveis ao sistema de abastecimento da região, dado o nível de investimentos que seria necessário para solucionar o problema, tais como novas obras de barramento, captação, adutoras e, possivelmente, novas estações de tratamento, tudo isso em localidades muito mais distantes que os atuais mananciais.

O principal problema relativo à proteção dos mananciais reside no fato de que o cuidado com essas importantes áreas não é atribuição do sistema gestor de recursos hídricos, mas sim dos municípios pertencentes à respectiva bacia produtora. É necessário que exista uma gestão integrada, pois só assim 
poderiam ser tomadas atitudes efetivas para proteção das áreas de mananciais, com planejamento conjunto e fiscalização adequada.

Os problemas de abastecimento hídrico da RMSP já são um ponto de discussão há bastante tempo, tanto que na década de 1990 a Agência Nacional de Águas (ANA) alertava para necessidade de adequações nos sistemas já existentes e construção de novos em seus relatórios técnicos, porém, poucos investimentos foram realizados desde então.

Admite-se que os objetivos propostos tenham sido relativamente alcançados, pois foi possível realizar uma análise satisfatória do comportamento pluviométrico da RMSP, na qual se verificou uma tendência significativa de aumento das precipitações, no entanto, a análise das relações entre os volumes de água armazenados nos mananciais dos Sistemas Produtores e a precipitação não pôde ser realizada como se desejava devido à ausência de dados.

Considera-se que, ainda que de maneira deficiente, foi possível identificar alguns indicadores de que os problemas de abastecimento na RMSP não estão vinculados somente à escassez de chuvas, pois em anos com totais de precipitação dentro das médias esperadas, como 2004, 2009 e 2012, alguns Sistemas apresentaram volumes médios de armazenamento bem abaixo de sua capacidade, enquanto outros apresentaram médias elevadas durante todo o período de análise.

Dessa maneira, pode-se considerar que a hipótese levantada, de que os problemas no abastecimento de água na RMSP decorrem também da falta de planejamento adequado e não somente da falta de chuvas, foi comprovada.

As tendências positivas para o aumento de precipitação identificadas indicam que a falta de precipitação não será um grave problema no futuro, no entanto a questão das chuvas mais concentradas, em especial no verão, poderão 
causar transtornos, relacionados a falta de infraestrutura para enfrentar eventos extremos, que poderão também afetar o abastecimento de água para a população.

É necessário pensar em estratégias de adaptação que sejam capazes de transformar os eventos extremos em benefícios para população, com a construção, por exemplo, de plantas superficiais de capitação de água da chuva em diferentes pontos da metrópole, criação de parques hídricos (para facilitar a infiltração da água), ampliação do tratamento de esgoto e recuperação dos cursos d'água. Tais atitudes não trariam uma solução definitiva ao problema, mas seriam capazes de minimizá-lo.

Alguns projetos já estão sendo implantados pelo poder público para tentar combater a falta de água, como por exemplo, a autorização em caráter emergencial da utilização dos volumes armazenados nos reservatórios do Sistema Equivalente, seguindo limites estipulados pela ANA em conjunto com o DAEE (2014) e o Plano Diretor de Abastecimento de Água da RMSP (2013) que a SABESP apresentou ao DAEE e ao Governo do Estado de São Paulo, tendo como horizonte de planejamento o ano de 2025, com o objetivo de atender toda a região do Alto Tietê e seus vizinhos, sugerindo aumento dos Sistemas Produtores de água existentes e agregação de novos mananciais, com ações de curto, médio e longo prazo.

O Plano Diretor de Abastecimento de Água da RMSP foi considerado insuficiente pelos órgãos de gestão, e um grupo de trabalho foi criado para reavaliar os estudos existentes e sugerir novas possibilidades, agora com um novo horizonte de planejamento até 2035. 


\section{Referências Bibliográficas}

AMBRIZZI, T. et al. Cenários regionalizados de clima no Brasil para o século XXI: Projeções de clima usando três modelos regionais. Relatório 3. Ministério do Meio Ambiente (MMA), Secretaria de Biodiversidade e Florestas (SBF), Diretoria de Conservação da Biodiversidade (DCBio). Mudanças Climáticas Globais e Efeitos sobre a Biodiversidade - Subprojeto: Caracterização do clima atual e definição das alterações climáticas para o território brasileiro ao longo do século XXI. Brasília, fevereiro 2007.

ANA - Agência Nacional de Águas. Disponível em < http://www2.ana.gov.br>. Acesso em: 10/04/2014.

AKIMOTO. H. et al . Global Air Quality and Pollution. Science, no 302, p. 1716-1719. DOI:10.1126/science.1092666, 2003.

AL BAKRI, D. Towards developing a geoscientific approach to sustainable agricultural and rural development. Environmental Geology, v. 40, n. 4-5, p. 543-556, fev. 2001. Disponível em: <www.sprinerlink.com>, Acesso em $10 / 11 / 2012$.

ALEXANDER, L. V.; et al. Global observed changes in daily climate extremes of Temperature and precipitation. J. Geophys. Res., 111, D05109, Doi:10.1029/2005JD006290, 2006.

AMORIM, M. C. C. T.: O clima Urbano de Presidente Prudente/ SP. Tese (Doutorado em Geografia) - Faculdade de Filosofia, Letras e Ciências Humanas, Universidade de São Paulo, São Paulo, 2000. 374p.

ANDREOTI, C. E. Comparação microclimática entre dois imóveis nos municípios de São Paulo e São Roque. Revista Geográfica Acadêmica, Goiás, v. 3, n.2, Dezembro de 2009.

AZEVEDO, T. R. de (2001a). Derivação antrópica do clima na Região Metropolitana de São Paulo abordada como função do ritmo semanal das atividades humanas. Tese de Doutorado. FFLCH, Universidade de São Paulo, São Paulo.

BACELLI, R. A presença da Companhia City em São Paulo e a implantação do primeiro bairro-jardim. Dissertação (Mestrado em Geografia Humana) Departamento de Geografia, Faculdade de Filosofia Letras e Ciências Humanas de São Paulo, São Paulo, 1982. 
BAENINGER, R. Interiorização da migração em São Paulo: novas territorialidades e novos desafios teóricos. In: Encontro Nacional de Estudos Populacionais, 14, Caxambu, 2004. Anais, Campinas: Abep, 2004.

BENFORD, R. D.; SNOW, D. A. Framing Processes and Social Movements: An Overview and Assessment. Annual Review of Sociology, 26: 611-39, 2000.

BERTONI, J. C; TUCCI, C. E. M. Precipitação. In: TUCCI, C. E. M. et al. Hidrologia: ciência e aplicação. Porto Alegre: UFRGS/ABHR, 4a ed., 2007.

BERTRAND, G. Paisagem e geografia física global: esboço metodológico. Caderno de Ciências da Terra, no 13, p. 1-27, 1971.

BERTRAND, G.; BERTRAND, C. Uma geografia transversal e de travessias: o meio ambiente através dos territórios e das temporalidades. Maringá: Massoni, 2007.

BÓGUS, L. M. M.; PASTERnAK, S. A. Cidade dos Anéis. Cadernos de Pesquisa do LAP, no 28, São Paulo, FAU/USP. 1998.

BÓGUS, L. M. M.; PASTERNAK, S. Como Anda São Paulo. In. BÓGUS, L. M. M.; PASTERNAK, S. (org.) Letra capital. Observatório das metrópoles. 2009.

BRANDÃO, A. M. de P. M. O clima urbano da cidade do Rio de Janeiro. Tese (Doutorado em Geografia). Departamento de Geografia, Faculdade de Filosofia Letras e Ciências Humanas, Universidade de São Paulo, São Paulo, 1996. 362p.

BRANCO, C. Energia elétrica e capital estrangeiro no Brasil. São Paulo: Alfa-Omega, 1975.

BREMAEKER, F. E. J. Os centros urbanos: 1950 a 1980. Revista Brasileira de Estatística, n47/180, São Paulo, 1986.

BRIGANTE, J; ESPÍNDOLA, E.L.G. Limnologia fluvial: um estudo no rio MogiGuaçu. São Carlos: Rima, 278 p, 2003.

BRUNA, G. C.; ROMÉRO, M. A.; PHILIPPI JR, A. Ecologia Urbana no Panorama Ambiental Metropolitano. In: BRUNA, G. C.; ROMÉRO, M. A.; PHILIPPI JR, A. (org.) Panorama ambiental da Metrópole de São Paulo. São Paulo: Signus Editora, 2004. 584p.

BUTLER, T. M.; LAWRENCE, M. G. The influence of megacities on global atmospheric chemistry: a modeling study. Environment Chemistry, 6, 219225, DOI:10.1071/EN08110, 2009. 
CABRAL, E. Tendências e variabilidade do fenômeno pluvial na Região Metropolitana de São Paulo e possíveis vinculações com o processo de urbanização. Tese (Doutorado em Geografia) - Departamento de Geografia, Faculdade de Filosofia, Letras e Ciências Humanas da Universidade de São Paulo, São Paulo, 2002, 183p.

CANO, W. A. Interiorização do Desenvolvimento Econômico no Estado de São Paulo (1920-1980). São Paulo: Fundação SEADE, v.1. a v. 3 (Coleção Economia Paulista). 1988.

CARMO, R.L.; et al . Água virtual, escassez e gestão: o Brasil como grande "exportador" de água. In: Ambiente e Sociedade. Campinas: ANPPAS. V.10, n. 2, ago/dez-2007.

CARVALHO, L.M.V.; JONES C.; SILVA DIAS, M. A. F. Intraseasonal large-scale circulations and mesoscale convective activity. In Tropical South America during the TRMM-LBA campaign. Journal of Geophysical Research, v. 29, p. 1-20, Aug. 2002.

CHANDLER, T. J. The climate of London. London: Hutchison of London, 1965.

CENSO DO IBGE 2010 - Disponível em: < http://censo2010.ibge.gov.br/pt/ >. Acesso em: 15/02/2012.

CONTI, J. B. Crescimento urbano e mudanças climáticas. Suplemento Cultural - O Estado de São Paulo, n¹49, p.3-4, 1979.

CONTI, J. B. Desertificação nos trópicos. Proposta de metodologia de estudo aplicada ao Nordeste Brasileiro. Tese (Livre-Docência em Geografia). Departamento de Geografia, Faculdade de Filosofia Letras e Ciências Humanas, Universidade de São Paulo, São Paulo, 1995. 208p.

COTTINGHAM, K.L.; CARPENTER, S.R. Population, community, and ecosystem variates as ecological indicators: phytoplankton responses to whole-lake enrichment. Ecol. Appl., vol. 8, no 2, p. 508-530, 1998.

CUSTÓDIO, V. Escassez de água e inundações na Região Metropolitana de São Paulo. São Paulo: Humanitas/FAPESP, 2012.

CUTTER, S. L.; BORUFF, B. J.; LYNN, S. W. Social Science Quarterly, Volume 84, Number 2, by the Southwestern Social Science Association. 2003.

DANNI, I. M. Aspectos Temporo-espaciais da Temperatura e Umidade relativa de Porto Alegre em Janeiro de 1982: contribuição ao estudo do clima urbano. Dissertação (Mestrado em Geografia Física) - Departamento de 
Geografia, Faculdade de Filosofia, Letras e Ciências Humanas, Universidade de São Paulo, São Pulo, 1987. 129p.

DENTENER, F.; STEVENSON, D. ; ELLINGSEN, K., et al . The global atmospheric environment for the next generation. Environ. Sci. Technol., no 40 (11), p. 3586-3594, 2006. DOI: 10.1021/es0523845.

DAEE- Departamento de Águas e Energia Elétrica. Disponível em < http://www.daee.sp.gov.br/>. Acesso em 10/10/2012.

DIAS, J.; SANTOS, L. A paisagem e o geossistema como possibilidade de leitura da expressão do espaço sócio-ambiental rural. Confins, no 1, 2. sem. 2007. Disponível em: <http://confins.revues.org/document10.html>. Acesso em: 18 nov. 2007.

DUFEK, A. S.; AMBRIZZI, T. Precipitation variability in São Paulo State, Brazil. Theoretical and Applied Climatology, v. 93, p. 167-178, 2007.

ELIASSON, I. The use of climate knowledge in urban planning. Landscape and Urban Planning, Amsterdam, n.48, p. 31 - 44, 2000.

ELWOOD, J.W; NEWBOLD, J.D; O'NEILL, R.V; Van Winkkle, V. Resource Spiralling an Operational Paradigm for Analysing Lotic Ecosystem. pp 327. In: T.D. Fontaine e S.M. Bartell (Eds.) Ann Arbor Science Publishers. 1985.

EMPLASA - Empresa Paulista de Planejamento Metropolitano. Disponível em <http://www.emplasa.sp.gov.br>. Acesso em 13/05/2012.

EMURB - Empresa Municipal de Urbanismo. Disponível em <http://www.prefeitura.sp.gov.br>. Acesso em 02/07/2012.

FARIA, V. Cinquenta anos de urbanização no Brasil. Revista Novos Estudos CEBRAP, São Paulo, no 29, p. 98-119. 1991.

GANHO, N. Insolação e Temperatura em Coimbra: Regimes médios e prováveis na estação meteorológica do IGU. Cadernos de Geografia, Coimbra, nº11, p. $55-85,1992$.

GARCÍA, M.C. M. La Cartografía del Fenómeno de la "Isla de Calor". Notes de Geografia Física, Barcelona, v. 19, p. 73 - 81, 1990.

GARCÍA, M.C. M. La Intensidad de la "Isla de Calor" de Barcelona. Comparación con otras Ciudades Españolas. Alísios Revista de Geografia, Barcelona, v.1, p. 47-53, 1991. 
GARCÍA, M.C. M. Unas Notas Históricas Acerca de la Climatología Urbana. Notes de Geografia Física, Barcelona, v. 20- 21, p. 137 - 141, 1991-1992.

GARCÍA, M.C. M. Una Propuesta de Terminología Castellana en Climatología Urbana. Investigaciones Geográficas, Barcelona, p. 89 - 98, 1997.

GAUSSEN, F.; BAGNOULS, H. Saison sèche et índice xetothermique. Bulletin de la Societé d'Histoire Naurel, Toulouse, tome 88, p. 193-239, 1953.

GOMEZ, A. L.; GARCIA, F. F. La Isla de Calor en Madrid: Avance de un Estudio de Clima Urbano. Estudios Geográficos, Madrid, n. 174, p. 5 - 34, 1984.

GÓMEZ, F.; GIL, L.; JABALOYES, J. Experimental investigation on the thermal comfort in the city: relationship with the green areas, interaction with the urban microclimate. . Building and Environment, Amsterdã, n.39, p.1077 - 1086, 2004.

GRISOTTO, L. E. G.; PHILIPPI JR, A. A questão dos recursos hídricos. In: BRUNA, G. C.; ROMÉRO, M. A.; PHILIPPI JR, A. (org.) Panorama ambiental da Metrópole de São Paulo. São Paulo: Signus Editora, 2004. 584p.

GURJAR, B. R; LELIEVELD, J. New Directions: Megacities and global change. Atmospheric Environment, no 39, p. 391-393, 2005.

GURJAR, B. R.; BUTLER, T. M.; LAWRENCE, M. G.; LELIEVELD, J. Evaluation of emissions and air quality in megacities. Atmospheric Environment, no 42, p. 1593-1606, 2008.

HANNINGAN, J. A. Sociologia Ambiental: A formação de uma perspectiva social. Lisboa: Instituto Piaget, 1995.

HANSSON, L; FAHRIG, L; MERRIAN, G. Mosaic Landscape and Ecological Processes. IALE Studies in Landscape Ecology 2, Chapman e Hall, London, 1995.

HARVEY, D. A condição pós-moderna. 17a Edição, São Paulo: Edições Loyola. 2008.

HAYLOCK, M. R.; et al. Trends in total and extreme South American rainfall 1960-2000 and links with sea surface temperature. J Climate 19:1490-1512. 2006.

HESPANHOL, I. Um novo paradigma para a gestão dos recursos hídricos. Estudos Avançados, São Paulo, v. 22, n. 63, p.131-158, fev. 2008. Disponível 
em: <http://www.scielo.br/pdf/ea/v22n63/v22n63a09.pdf>. Acesso em: $10 / 12 / 2014$.

HENRY-SILVA, G.G; CAMARGO, A.F.M. Impacto do lançamento de efluentes urbanos sobre alguns ecossistemas aquáticos do município de Rio Claro (SP). Revista Ciências Biológicas e do Ambiente, no 2(3), p.317-330, 2000.

HOUGH, M. Naturaleza y Ciudad: Planificación urbana y procesos ecológicos. Barcelona: Editora Gustavo Gili S.A, 1998. 281p.

HULME, M. Why We Disagree About Climate Change: Understanding Controversy, Inaction and Opportunity. Cambrigde University Press, Cambridge, 2009.

INSTITUTO BRASILEIRO DE GEOGRAFIA E ESTATÍSTICA - IBGE, 2004, Atlas de Saneamento, Rio de Janeiro, RJ, Brasil.

INSTITUTO AKATU. Pesquisa no. 7: Como e por que os brasileiros praticam o consumo consciente? São Paulo: Instituto Akatu, 2007. Disponível em: <http//www.akatu.org.br>. Acesso em: 15/10/2012.

IPCC Climate Change 2007: Impacts, Adaptation, and Vulnerability. Contribution of Working Group II to the Fourth Assessment Report of the Intergovernmental Panel on Climate Change. Cambridge University Press, Cambridge, United Kingdom, 1000 pp. 2007.

ISER - INSTITUTO DE ESTUDOS DA RELIGIÃO. Pesquisa: 0 que as lideranças brasileiras pensam sobre mudanças climáticas e o engajamento do Brasil. Relatório de Divulgação, 2008.

JACOB, D. J. Introduction to atmospheric chemistry. Princeton University Press, New Jersey, 1999.

JACOB, D. J.; WINNER, D. A. Effect of climate change on air quality. Atmospheric Environment, no 43, p. 51-63, 2009.

KONDO, H.; TOYOTA, I.; GUIMARÃES, T. F.; NUCCI, C. N. Mananciais e Abastecimento de água. In: BRUNA, G. C.; ROMÉRO, M. A.; PHILIPPI JR, A. (org.) Panorama ambiental da Metrópole de São Paulo. São Paulo: Signus Editora, 2004. 584p.

KOWARICK, L. A espoliação urbana. 2a Edição. Rio de Janeiro: Paz e Terra. 1993. 
LAHSEN, M. A science-policy interface in the global south: the politics of carbons sinksand science in Brazil. Climate Change, 97: 339-372, 2009.

LAHSEN, M. The Dualities of Brazilian Climate Politics and Policy presentation delivered in March 2010 at the "Comparing National Responses to Climate Change" panel at Institut du Developpement Durable et des Relations Internationales (IDDRI) in Paris, France, 2010a. Disponível em < http://compon.org/content/brazil> Acesso em: 15/10/2012.

LAHSEN, M. The social status of climate change knowledge: an editorial essay. Climate Change, v.1, March/April, 2010b.

LAMPARELLI, C. A metropolização como uma das formas de urbanização. In. RIBEIRO, A. C.; MACHADO, D. T. (org.). Metropolização e rede urbana, perspectivas dos anos 90. Rio de Janeiro: IPPUR/UFRJ, 1990.

LANDSBERG, H. E. Meteorological observations in urban areas. Meteorological Monographs, v. 11, n. 33, p. 91-99, october 1970.

LANDSBERG, M. E. The urban climate. New York: Academia Press, 1981.

LANGENBUCH, J. R. A estruturação da Grande São Paulo, estudos de geografia urbana. Rio de Janeiro: IBGE. 1971.

LAWRENCE, M. G.; BUTLER, T. M.; STEINKAMP, J; GURJAR, B. R.; LELIEVELD, J. Regional pollution potentials of megacities and other major population centers. Atmos. Chem. Phys., no 7, p. 3969-3987, 2007.

LAZAR, R.; PODESSER, A. An urban climate analysis of Graz and its signi"cance for urban planning in the tributary valleys east of Graz (Austria). Atmospheric Environment, Amsterdã, n.33, p. 4195 - 4209, 1999.

LIKENS, G. E. Biogeochemistry, the watershed approach: some uses and limitations. In: Frontiers of Catchment Biogeochemistry. CSIRO Land and Water, Canberra, Australia. Marine and Freshwater Research, n052 (1), p. 5-12, 2001.

LOMBARDO, M.A. Ilha de Calor nas Metrópoles: o exemplo de São Paulo. São Paulo: Hucitec, 1985. 244p.

MARENGO, J. A.; JONES, R.; ALVES, L. M.; VALVERDE, M. Future change of temperature and precipitation extremes in South America as derived from the PRECIS regional climate modeling system. International Journal of Climatology, v. 29, Issue 15, p. 2241-2255, 2009a. 
MARENGO, J. A.; et al . Future Change of Climate in South America in the late XXI century: Intercomparison of scenarios from three regional climate models. Climate Dinamics. International Journal of Climatology, 2009b.

MARENGO, J. A.; RUSTICUCCI, M.; PENALBA, O.; RENON, M. An intercomparison of observed and simulate extreme rainfall and temperature events during the last half of twentieth century, part 2: historical trends. Climate Change. International Journal of Climatology, 2009c.

MARENGO, J. A. et al. The drought of Amazonia in 2005. Journal of Climate, v.21, p.495-516, 2008a.

MARENGO, J. A. Hydro-climatic: and ecological behaviour of the drought of Amazonia in 2005. Philosophical Transactions of the Royal Society of London. Biological Sciences, v.21, p.1-6, 2008b.

MARENGO, J. A. Mudanças climáticas globais e seus efeitos sobre a biodiversidade - caracterização do clima atual e definição das alterações climáticas para o território brasileiro ao longo do século XXI. 2. ed. Brasília: Ministério do Meio Ambiente, 2007. v.1, p.214.

MARENGO, J. A. et al. Eventos extremos em cenários regionalizados de clima no Brasil e América do Sul para o Século XXI: Projeções de clima futuro usando três modelos regionais. Relatório 5, Ministério do Meio Ambiente (MMA), Secretaria de Biodiversidade e Florestas (SBF), Diretoria de Conservação da Biodiversidade (DCBio). Mudanças Climáticas Globais e Efeitos sobre a Biodiversidade - Subprojeto: Caracterização do clima atual e definição das alterações climáticas para o território brasileiro ao longo do século XXI. Brasília, fevereiro 2007.

MARENGO, J. A.; DIAS, P. S. Mudanças climáticas globais e seus impactos nos recursos hídricos. In: Rebouças, A. C.; Braga, B.; Tundisi, J. G. (Ed.) Águas doces no Brasil: capital ecológico, uso e conservação. 3. ed. São Paulo: Instituto de Estudo Avançados da USP, Academia Brasileira de Ciências, 2006. p.63-109.

MARTINE, G. O lugar do espaço na equação população/meio ambiente. Revista Brasileira de Estudos da População, v. 24, p. 181-190, 2007.

MELO, D. Geossistemas: sistemas territoriais naturais. In: SIMPÓSIO BRASILEIRO DE GEOGRAFIA APLICADA, 6, Curitiba. Anais... Curitiba: UFPR, 1997. CDROM. Não paginado. 
MENDONÇA, F. de A. O clima e o Planejamento Urbano de Cidades de Porte Médio e Pequeno: proposição metodológica para estudo e aplicação à cidade de Londrina, PR. Tese (Doutorado em Geografia Física) - Faculdade de Filosofia, Letras e Ciências Humanas, Universidade de São Paulo, São Paulo, 1994. 322p.

MENDONÇA, F. A Clima e planejamento urbano em Londrina. Clima Urbano. Org. Mendonça, F; Monteiro, C. A de F. São Paulo: Contexto, 2003.

Miguel, A. R.; BeVILACQUA, N.; GUERRA, P. A. D. V.; BAPTISTELLI, S. C. Tratamento de águas residuárias domésticas. In: BRUNA, G. C.; ROMÉRO, M. A.; PHILIPPI JR, A. (org.) Panorama ambiental da Metrópole de São Paulo. São Paulo: Signus Editora, 2004. 584p.

MILLER JÚNIOR, G Tyler. Ciência Ambiental. 11. ed. São Paulo: Thomson Learning Edições, 2006. 592 p.

MONTEIRO, C.A.F. \& MENDONÇA, F. (Org.) Clima Urbano. São Paulo: Editora Contexto, 2003.

MONTEIRO, A. O clima urbano do Porto: contribuições para a definição das estratégias de planejamento e ordenamento do território. Fundação Calouste Gulbenkian, Junta Nacional de Investigação Científica e Tecnológica, 1997. 485p.

MONTEIRO, C. A. de F. Teoria e Clima Urbano. São Pulo: IGEOG/USP, 1976. 181p. (Série Teses e Monografias, 25).

MONTEIRO, C. A. de F. O Clima e a Organização do Espaço no Estado de São Paulo: problemas e perspectivas. São Paulo: IGOG/USP, 1976 . 54p. (Série Teses e Monografias).

MONTEIRO, C. A de F. A dinâmica climática e as chuvas do estado de São Paulo: estudo em forma de Atlas. Instituto de Geografia, Universidade de São Paulo, 1973.

MONTEIRO, C. A. de F. Clima e Excepcionalismo: conjecturas sobre o desempenho da atmosfera como fenômeno Geográfico. Florianópolis/SC: ed. da UFSC, 1991. 241p.

MONTEIRO, C. A. de F. Por um suporte teórico e prático para estimular estudos geográficos do clima urbano no Brasil. GEOSUL , Florianópolis, v.5, n.9, p. 7-19, 1990.

MONTEIRO, C. A. de F. Adentrar a cidade para tomar-lhe a temperatura. GEOSUL. Florianópolis, v.5, n.9, p.61-79, 1990. 
MONTEIRO, C. A. de F. A cidade como processo derivador ambiental e estrutura geradora de um "clima urbano". GEOSUL, Florianópolis, v.5, n.9. p. 80-114, 1990.

MONTEIRO, C. A. F. Geossistemas: a história de uma procura. São Paulo: Contexto, 2000.

NEWMAN, P. The environmental impact of cities. In Environment and Urbanization. London: IIED. V.18, n० .2, p. 275-295.

NOBRE, C, A. Mudança Climática e o Brasil - Contextualização. In. CGEE. Mudança do clima no Brasil: vulnerabilidade, impactos e adaptação. Revista Parcerias Estratégicas. Edição Especial - Número 27, dezembro de 2008a.

NOBRE, C, A., SAMPAIO G. e SALAZAR, L. Cenários de mudança climática para a América do Sul para o final do século 21. In. CGEE. Mudança do clima no Brasil: vulnerabilidade, impactos e adaptação. Revista Parcerias Estratégicas. Edição Especial - Número 27, dezembro de 2008b.

NUNES, L. H. Distribuição espaço-temporal da pluviosidade no Estado de São Paulo: variabilidade, tendências, processos intervenientes. Tese (Doutorado em Engenharia) - Escola Politécnica, Universidade de São Paulo, São Paulo, 1997. 192p.

OJIMA, R. Dimensões da urbanização dispersa e proposta metodológica para estudos comparativos: uma abordagem socioespacial em aglomerações urbanas brasileiras. Revista Brasileira de Estudos da População, v. 24, n. 2, p. $277-$ $300,2007$.

OKE, T.R. Boundary Layer Climates. London: Methuem eLtd. A. Halsted Press Book, John Wiley eSons, New York, 1978, 372p.

OKE, T.R. Climat impactos of urbanization. In: Interations of energy and climate. Procedding. Dordrecht/Holanda: D. Heider Publishing Company, p. 339 - 361, 1980.

OKE, T.R. The energetic basis of the urban heat island. Quarterly Journal of the Royal Meteorological Society, v.108, n.455, p.1-24, jan. 1982.

OKE, T.R. Towards a prescription for the greater use of climatic principles in settlement planning. Energy and Buildings, Climatology, 25th International Geographical Congress Symposium n.0 18: Applied Geography Zurich, 19-30.1984 
OKTAY, D. Design with the climate in housing environments:an analysis in Northern Cyprus. Building and Environment, Amsterdã, n.37, p.1003 - 1012, 2002.

PACHECO, C. A. Fragmentação da nação. Campinas : Instituto de Economia/ UNICAMP, 1998.

PASSOS, M. M. Geossistema: um novo paradigma? In: SIMPÓSIO BRASILEIRO DE GEOGRAFIA APLICADA, 6. Curitiba. Anais... Curitiba: UFPR, 1997. CD ROM. Não paginado.

PAULEIT, S.; ENNOS, R.; GOLDING, Y. Modeling the environmental impacts of urban land use and land cover change a study in Merseyside, UK. Landscape and Urban Planning, Amsterdã, n.71, p. 295 - 310, 2005.

PINHEIRO, G.M. As Chuvas Extremas e Suas Repercussões No Espaço Urbano de Bauru/SP: 1978 a 2008. Curitiba: UFPR, 2012.

PITTON, S. E. C. As Cidades como Indicadores de alterações térmicas. Tese (Doutorado em Geografia Física)- Faculdade de Filosofia, Letras e Ciências Humanas, Universidade de São Paulo, São Paulo, 1997. 272p.

PETRONE, P. A cidade de São Paulo no século XX. In: Azevedo, A. (org.). A Cidade de São Paulo. São Paulo: Nacional - AGB/SP, v.II, 1958.

RIBEIRO, W.C. Impactos das mudanças climáticas em cidades no Brasil. In. CGEE. Mudança do clima no Brasil: vulnerabilidade, impactos e adaptação. Revista Parcerias Estratégicas. Edição Especial - Número 27, dezembro de 2008.

ROSS, J. Ecogeografia do Brasil: subsídios para planejamento ambiental. São Paulo: Oficina de Textos, 2006.

ROSS, J. L. S. Ecogeografia do Brasil: subsídios para planejamento ambiental. São Paulo: Oficina de Textos, 2006.

SANDERSON, M; GORSKI, R. The effect of metropolitan Detroit-Windsor on precipitation. Journal of Applied. Meteorology. 1978.

SANT'ANNA NETO, J. L. As chuvas no Estado de São Paulo. Tese (Doutorado em Geografia) - Departamento de Geografia, Faculdade de Filosofia, Letras e Ciências Humanas da Universidade de São Paulo, São Paulo. 1995. 252p. 
SANT'ANNA NETO, J. L. (org) Os Climas das Cidades Brasileiras. Presidente Prudente: UNESP, 2002. 227p.

SANTOS, M. Metrópole corporativa e fragmentada. São Paulo: Nobel. 1990.

SANTOS, M. Por uma economia política da cidade. São Paulo: Hucitec. 1994

SEARCY, J. K; HARDISON, C. H. Double-Mass curves. In: LANGBEIN, W. B. Manual of Hydrology: Part 1. General Surface-Water Techniques. Washington, D.C.: General Survey Water Supply Paper 1541 - B, 1960.

SCHIAVETTI, A.; CAMARGO, A. F. M. Conceitos de Bacias Hidrográficas: teorias e aplicações. Ilhéus, BA : Editus, 2002. 293p.

SHIKLOMANOV, I. A., 1999, World water resources at the beginning of the $\mathbf{2 1}^{\text {st }}$ century. STATE HYDROLOGICAL INSTITUTE - SHI, UNESCO/IPH. Disponível em < http://webworld.unesco.org > . Acesso em 10/12/2013

SHIKLOMANOV, I. A. et al. The dynamics of river water inflow to the Arctic Ocean. In: LEWIS, E. L. et al. (Ed.) The Freshwater Budget of the Arctic Ocean. Dordrecht, Netherlands: Kluwer Academic Publishers, 2000. p.281-96.

SIGRH- Sistema Integrado de Gerenciamento dos Recursos Hídricos. Disponível em < http://www.sigrh.sp.gov.br>. Acesso em 10/11/2012.

SILVA, C. B.; SANT'ANNA NETO, J. L.; TOMMASELLI, J. T. G.; PASSOS, M. M.. Dinâmica Atmosférica e Análise Geoestatística do Clima da Área de Integração Paisagística "Raia Divisória" SP/ PR/ MS: Uma Proposta de Tipologia Climática. Revista Brasileira de Climatologia, v.2, p. 53 - 70, dezembro de 2006.

SILVA DIAS, M. A. F.; DIAS, J.; CARVALHO, L. M. V.; FREITAS, E. D.; SILVA DIAS, P. L. Changes in extreme daily rainfall for São Pau lo, Brazil. Climatic Change, v. 116 (3), 705-722, 2013. DOI 10.1007/s10584-012-0504-7.

SMITH, S.W; PETRERE, JR. Caracterização limnológica da bacia de drenagem do Rio Sorocaba, São Paulo, Brasil. Acta Limnologica Brasiliensia, no12, p. 173$186,2001$.

SNOW, D. A., et al . Frame Alignment Processes, Micromobilization, and Movement Participation. American Sociological Review, Vol. 51, No. 4: 464481, 1986.

SOUZA, M. A. A. A identidade da metrópole: a verticalização em São Paulo. São Paulo: Hucitec; Edusp, 1994. 
SOLECKI, W. D.; ROSENZWEIG, C.; PARSHALL, L.; POPE, G.; CLARK, M.; COX, J.; WIENCKE, M. Mitigation of the heat island effect in urban New Jersey. Environmental Hazards, Amsterdã, n.6, p. 39 - 49, 2005.

SPIEGEL, M. R. Estatística. São Paulo: Makron Books, 1994. 643p.

STEEMERS, K. Energy and the city: density, buildings and transport. Energy and Buildings, Amsterdam, n. 35, p. 3 - 14, 2003.

SUKOPP, H. Human-caused impact on preserved vegetation. Landscape and Urban Planning, Amsterdam, n.68, p. 347 - 355, 2004.

SVENSSON, M. K.; ELIASSON, I. Diurnal air temperatures in built-up areas in relation to urban planning. Landscape and Urban Planning , Amsterdã, n.61, p. $37-54,2002$.

TARIFA, J. R. Análise Comparativa da Temperatura e Umidade na Área Urbana e Rural de São José dos Campos (SP). GEOGRAFIA, v. 2, n. 4, p. 59 - 80, outubro 1977.

TARIFA, J. R. \& ARMANI, G. "Os climas naturais" in TARIFA, J. R. \& AZEVEDO, T. R. de, orgs, Os climas da cidade de São Paulo: teoria e prática. GEOUSP Novos Caminhos, n.4. Departamento de Geografia, FFLCH, USP, São Paulo, 2001.

THORP, J.H.; THOMS, M.C.; DELONG, M.D. The riverine ecosystem synthesis: biocomplexity in river networks across space and time. River Research e Applications. no 22, p.123-147. 2006.

TONIOLO, W. J. Desenvolvimento institucional do saneamento básico em São Paulo: fatores determinantes. Revista DAE, São Paulo, v. 46, no 147, 1986.

TORRES, H.G. Fronteira Paulistana. Anais do XIV Encontro Nacional de Estudos Populacionais, Caxambu: ABEP. 2004.

TUNDISI, J. E. M. Indicadores da qualidade da bacia hidrográfica para gestão integrada dos recursos hídricos. Estudo de caso: Bacia hidrográfica do Médio Tocantins/ José Eduardo Matsumura Tundisi. - São Carlos. UFSCar, 152p, 2006.

TUNDISI, J. G. Recursos hídricos no futuro: problemas e soluções. Estud. av. São Paulo, v. 22, no 63, 2008.

TUNDISI, J. G.; MATSUMURA-TUNDISI, T. -The Lobo-Broa: Ecosystem Researchll, in: J. G. Tundisi; C. E. M. Bicudo; T. Matsumura-Tundisi (eds.). 
Limnology in Brazil. Brazilian Academy of Sciences, Brazilian Limnological Society, 1995.

TUNDISI, J. G.; SAIJO, Y. eds. Limnological Studies on the Rio Doce Valley Lakes, Brazil. Brazilian Academy of Sciences, EESC/USP, CRHEA, 1997.

TUNDISI, J. G.; SCHIEL, D. A bacia hidrográfica como laboratório experimental para o ensino de Ciências, Geografia e Educação Ambiental. In: Schiel, D.; Mascarenhas, S.; Valeiras, N.; Santos, S. A. M. (org.). 0 estudo de bacias hidrográficas, uma estratégia para educação ambiental. São Carlos, Rima, p. 12-17. Valeiras, N e Lozada, R. 2002.

TUNDISI, J.G. Água no século XXI: enfrentando a escassez. São Carlos. Ed. Rima, 248p, 2003.

TUCCI, C. E. M. et al. Hidrologia: ciência e aplicação. Porto Alegre: UFRGS/ABRH, 4a ed.,2007.

UNEP (1996), An Urbanizing World: Global Report on Human Settlements 1996, UNEP/Habitat, Oxford University Press, Oxford.

UNITED NATIONS EDUCATIONAL, SCIENTIFIC AND CULTURAL ORGANIZATION UNESCO, 2006, Water a shared responsibility - The United Nations World Water Development Report 2. 1 ed. New York, UNESCO e Berghahn Books.

UNFPA - UNITED NATIONS POPULATION FUND. State of World Population 2007: Unleashing the potential of urban growth. New York: UNFPA, 2007. UNITED NATIONS, United Nations Expert Group Meeting on Population Distribution, Urbanization, Internal Migration and Development. New York. This publication has been issued without formal editing. Economical and Social Affairs. ESA/P/WP.206 Copyright United Nations. Printed in the United Nations, New York. 2008.

VANNOTE, R. L.; MINSHALL, G. W.; CUMMINS, K. W.; SEDELL, J. R.; CUSHING, C. E.. The River Continuum Concept. Canadian Journal of Fisheries and Aquatic Sciences, n037, p. 130-137, 1980.

VERÁS, M. P. B. Enigmas da gestão da cidade mundial de São Paulo: políticas urbanas entre o local e o global. In. SOUZA, M. A. A.; et al . (orgs.) Metrópole e Globalização: conhecendo a cidade de São Paulo. São Paulo: Cedesp, 1999.

VIANA, S. S. M. Caracterização do Clima Urbano em Teodoro Sampaio/ SP. Presidente Prudente, 2006. 190p. Dissertação (Mestrado em Geografia) Faculdade de Ciências e Tecnologia , UNESP. 
XAVIER, T. M. B. S.; XAVIER, A. F. S.; SILVA DIAS, M. A. F. Evolução da precipitação diária num ambiente urbano: O Caso da Cidade de São Paulo. Rev. Bras. Meteor., 9, 1, 44-53, 1994.

ZAVATTINI, J. A. A dinâmica atmosférica e as chuvas no Mato Grosso do Sul. Tese (Doutorado em Geografia) - Departamento de Geografia, Faculdade de Filosofia, Letras e Ciências Humanas da Universidade de São Paulo, São Paulo. 1990

ZAVATtini, J. A. As chuvas e as massas de ar no Mato Grosso do Sul: estudos climáticos com vista à regionalização climática. São Paulo: Cultura Acadêmica, 2009. 129p.

ZENG, G.; PYLE, J. A.; YOUNG, P. J. Impact of climate change on tropospheric ozone and its global budgets. Atmos. Chem Phys., no 8, p. 369-387, 2008.

WALDMAN, M. Água e Metrópole: limite e expectativas do tempo. Tese (Doutorado em Geografia). Departamento de Geografia, Faculdade de Filosofia Letras e Ciências Humanas, Universidade de São Paulo, São Paulo, 2005.

WORLD HEALTH ORGANIZATION - WHO, UNITED NATIONS CHILDREN'S FUNDS - UNICEF, 2005, Water for life: Making it Happen. 1 ed. Genebra, Suíça, WHO Press. 


\section{APÊNDICES}




\section{Apêndice 01}

Valores mensais - Série de dados de precipitação 


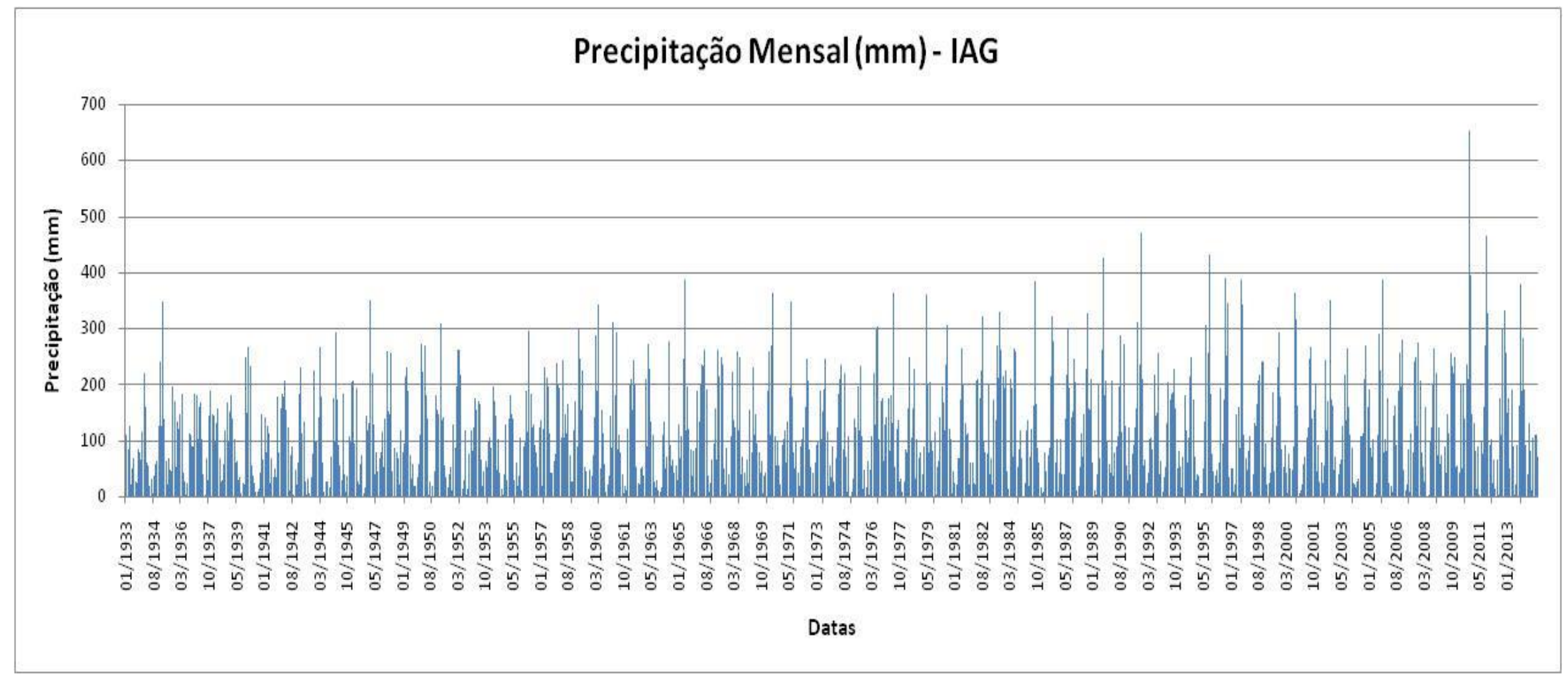




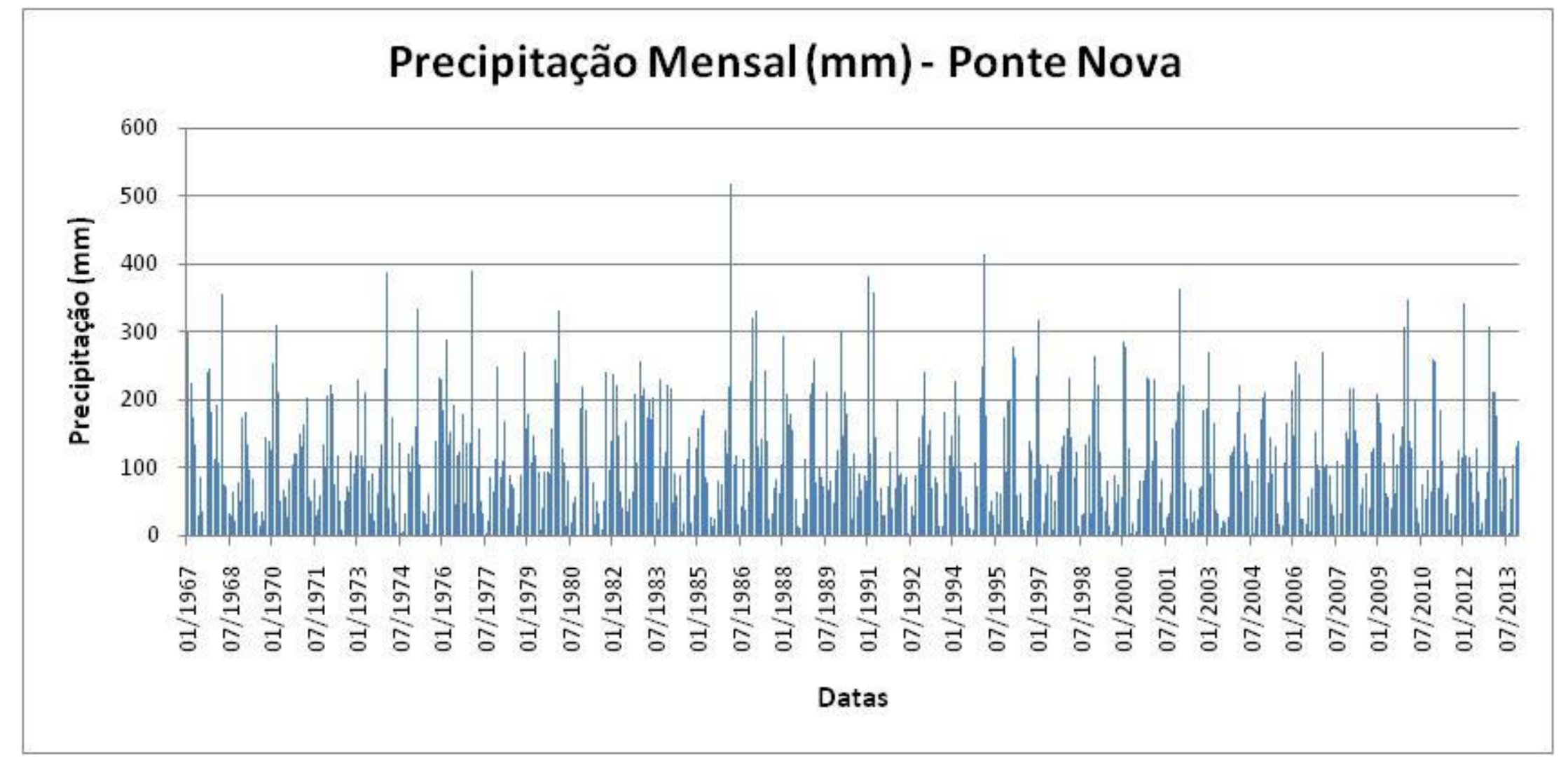




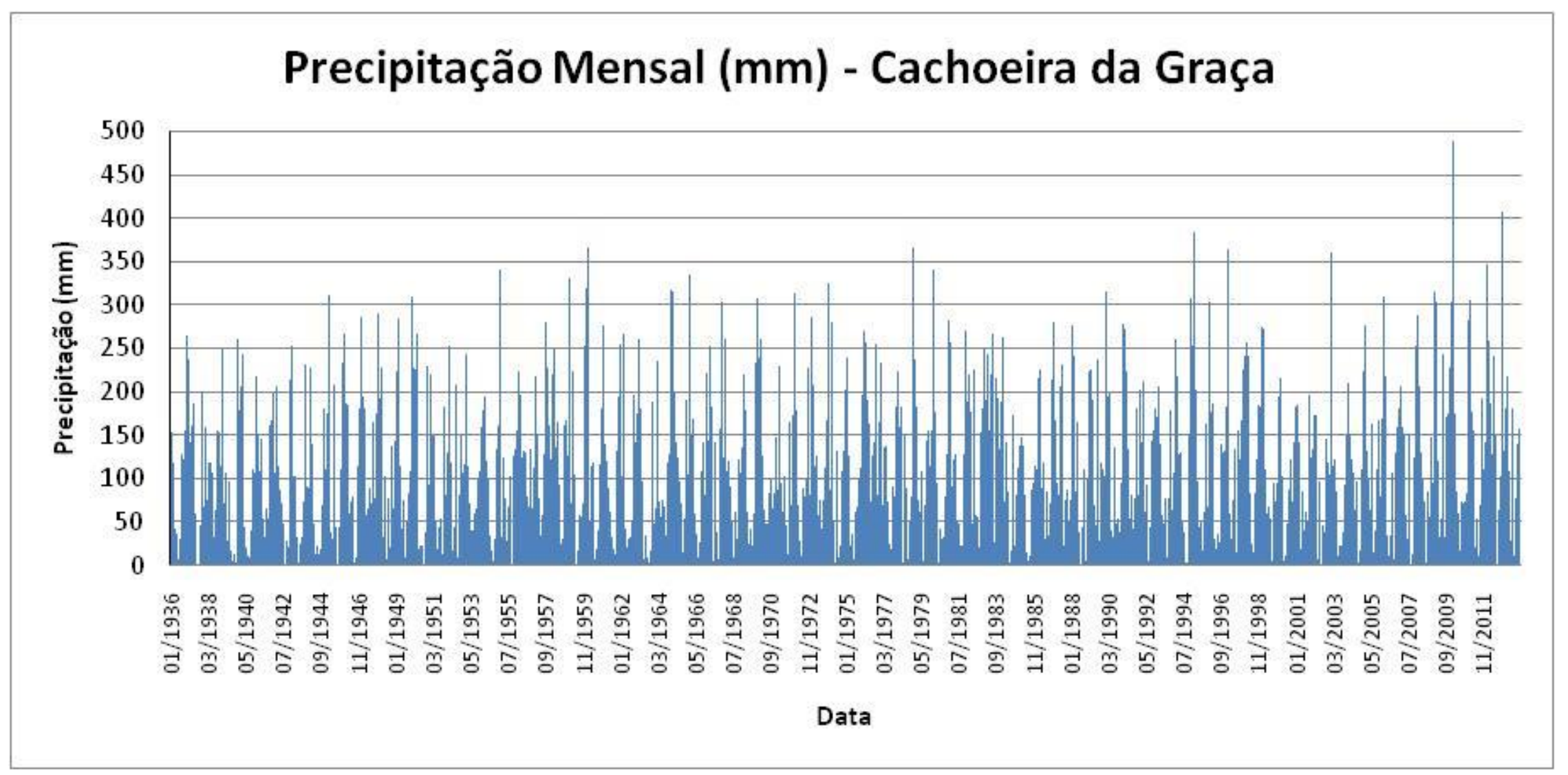




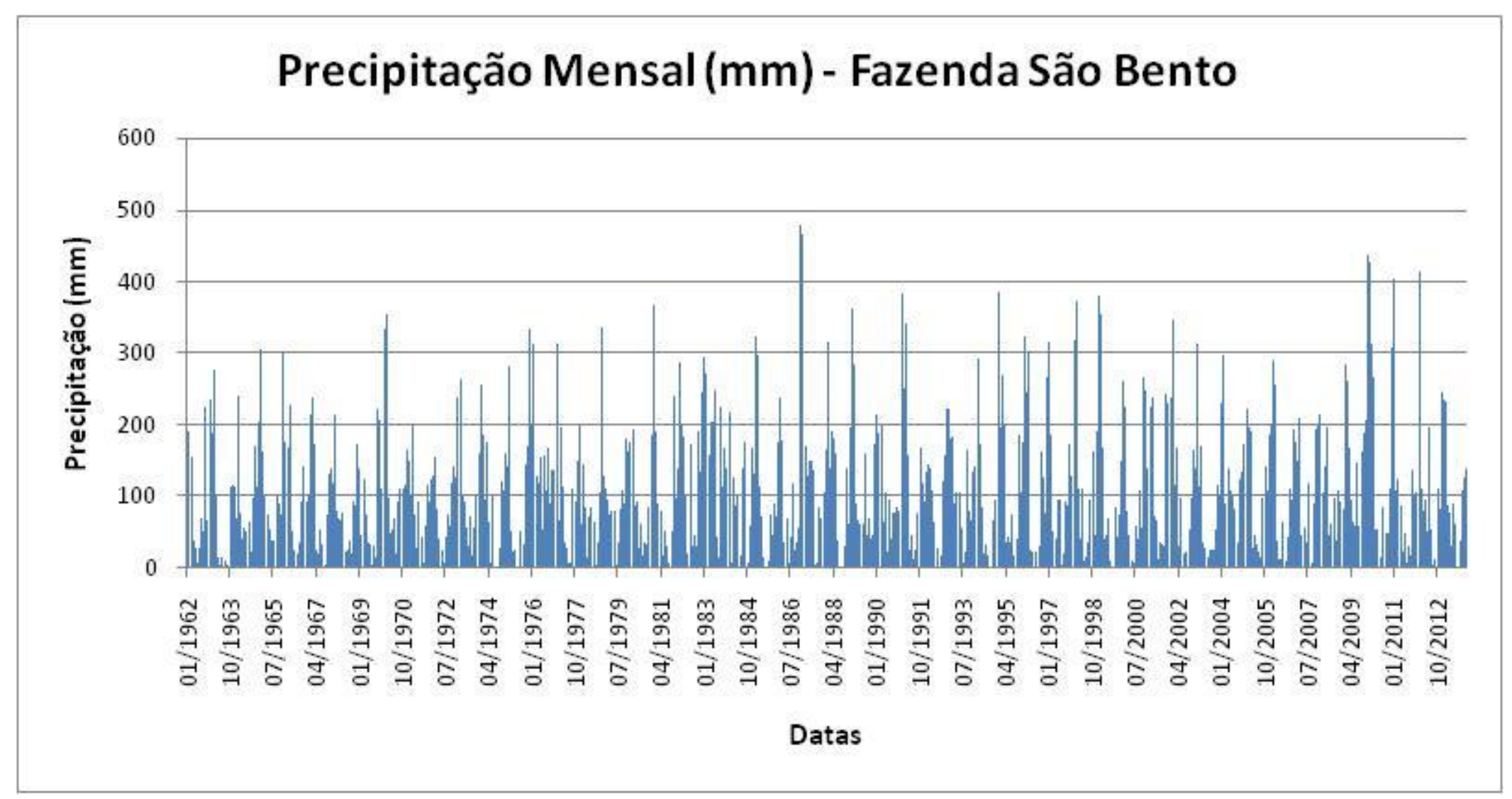




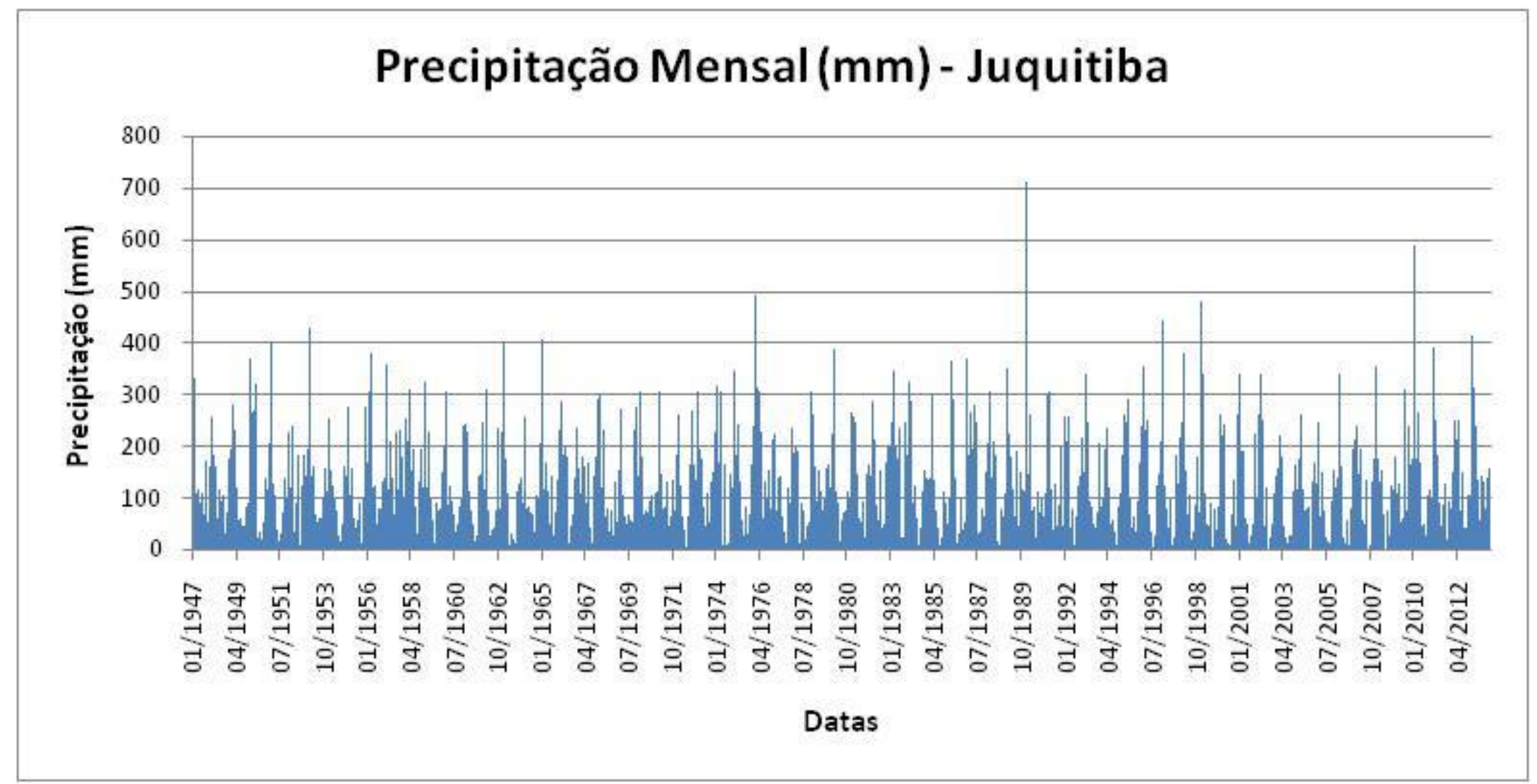




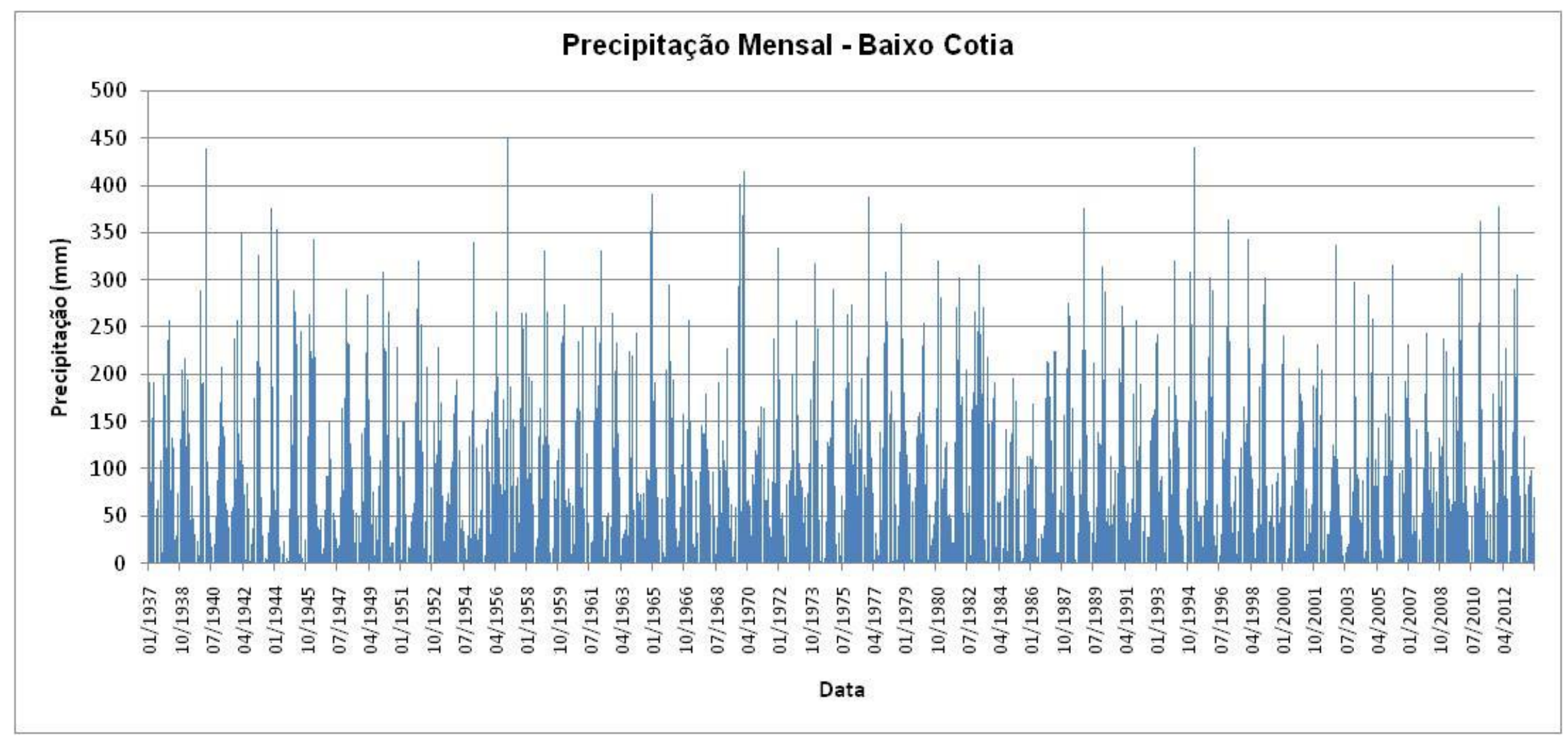




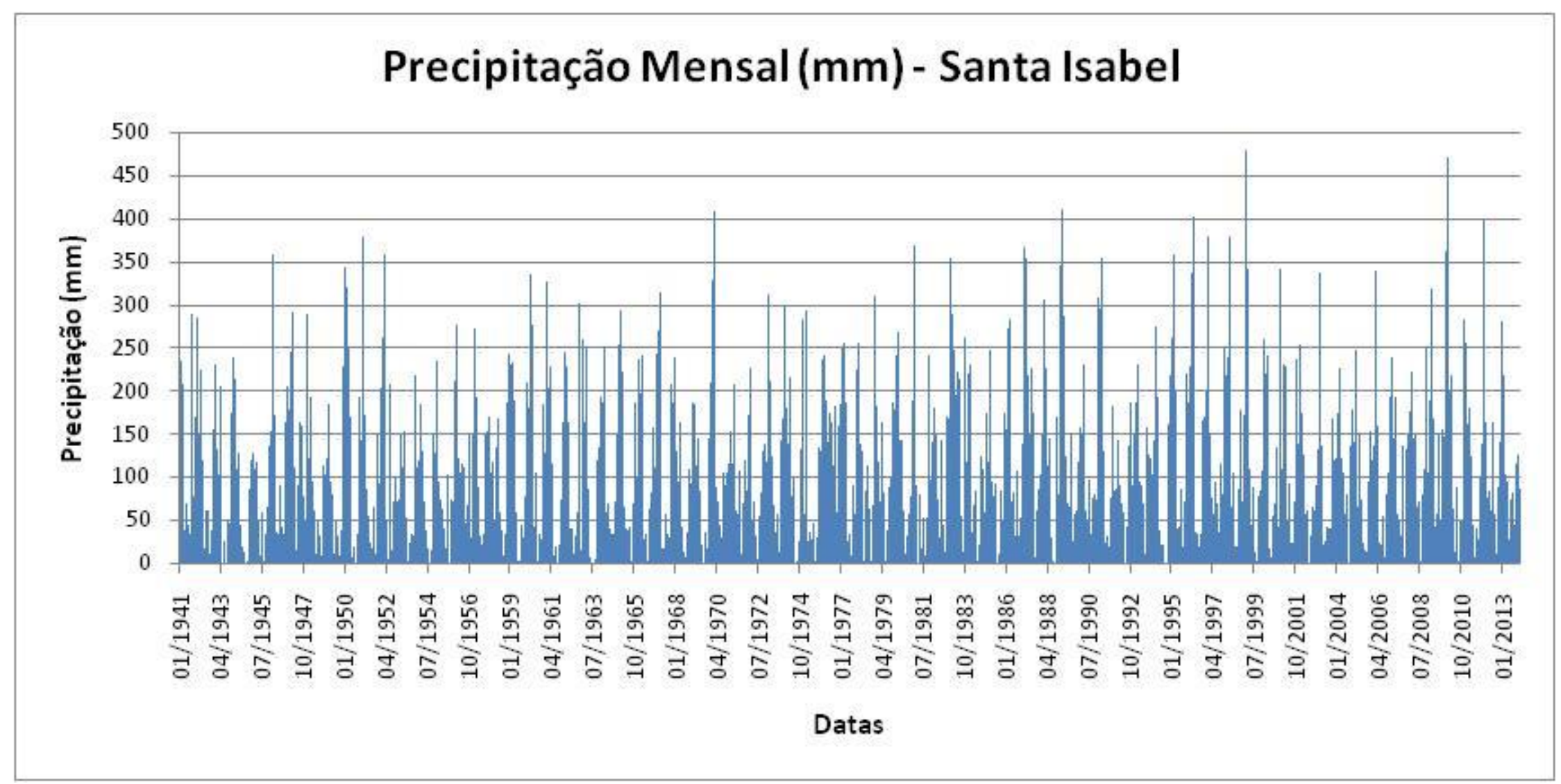




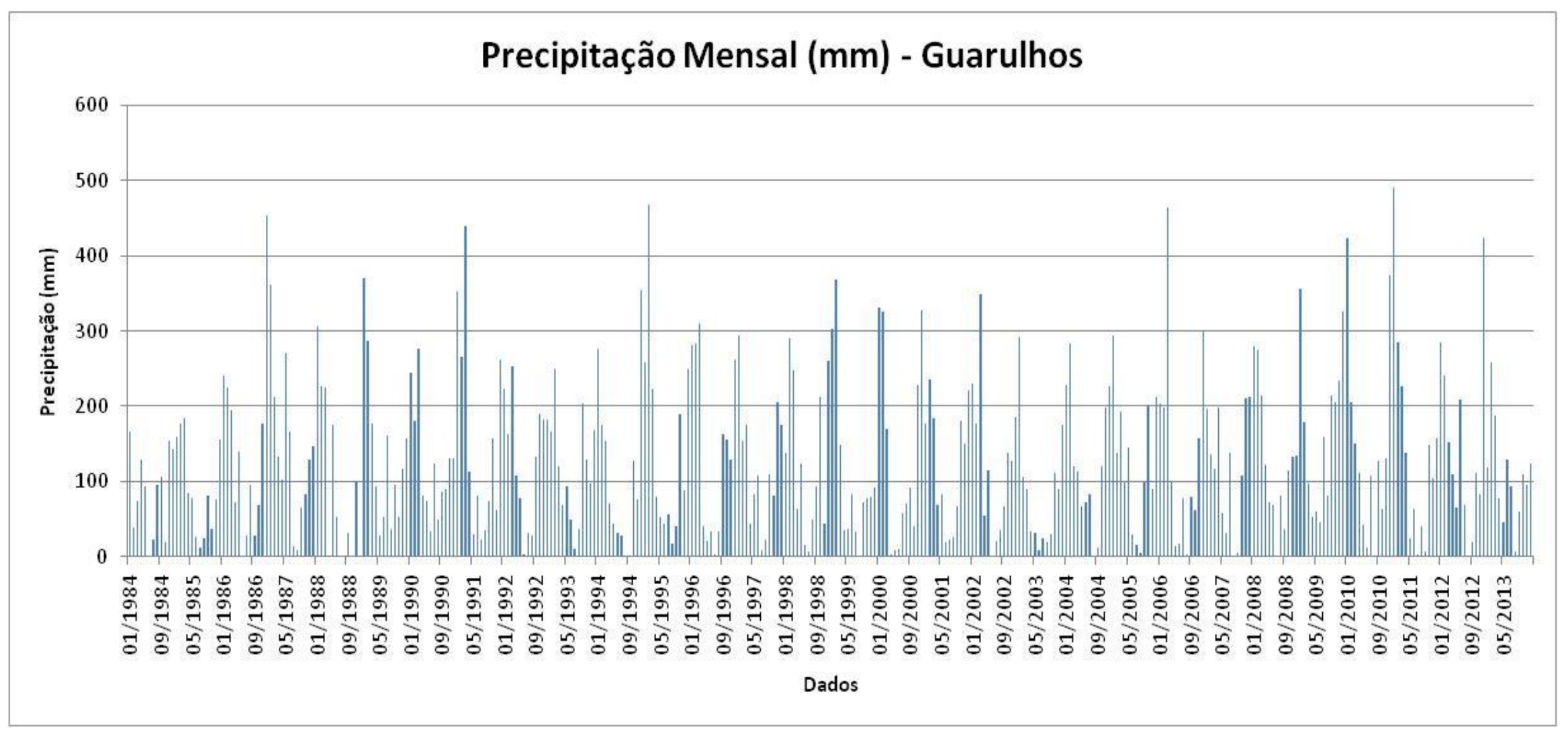




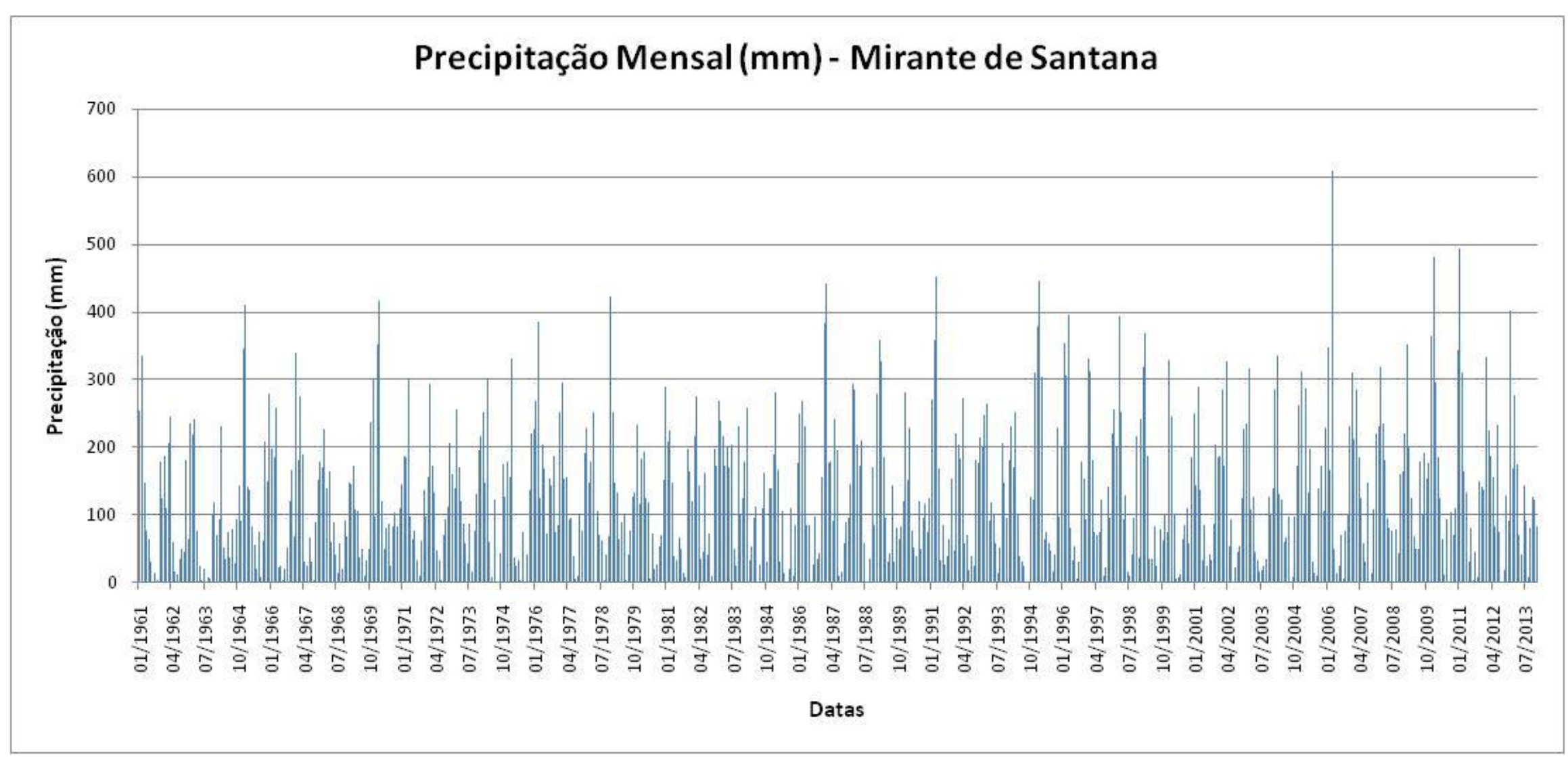




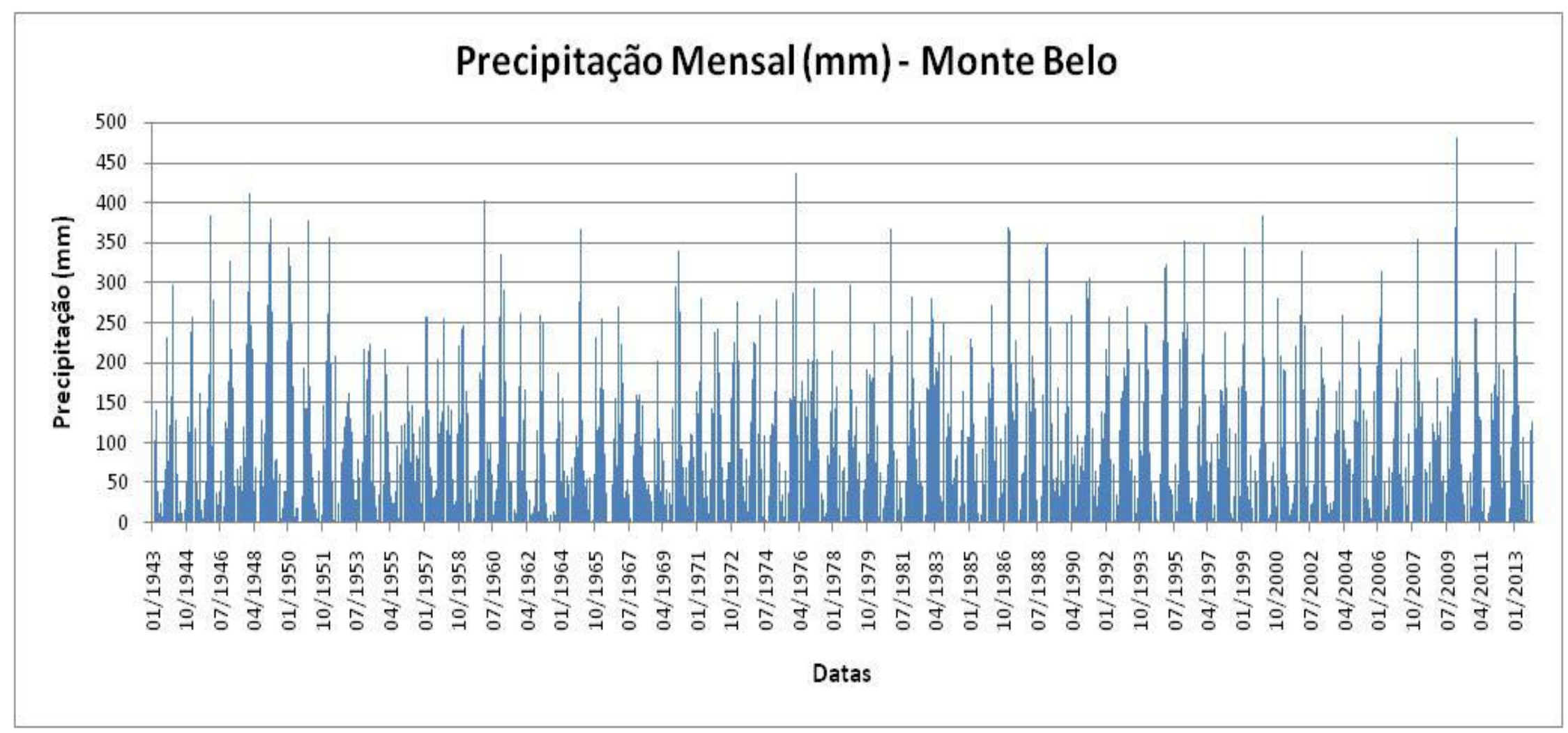




\section{Apêndice 02}

Dados de precipitação diários - comparação estações IAG, Mirante de Santana e Guarulhos. 


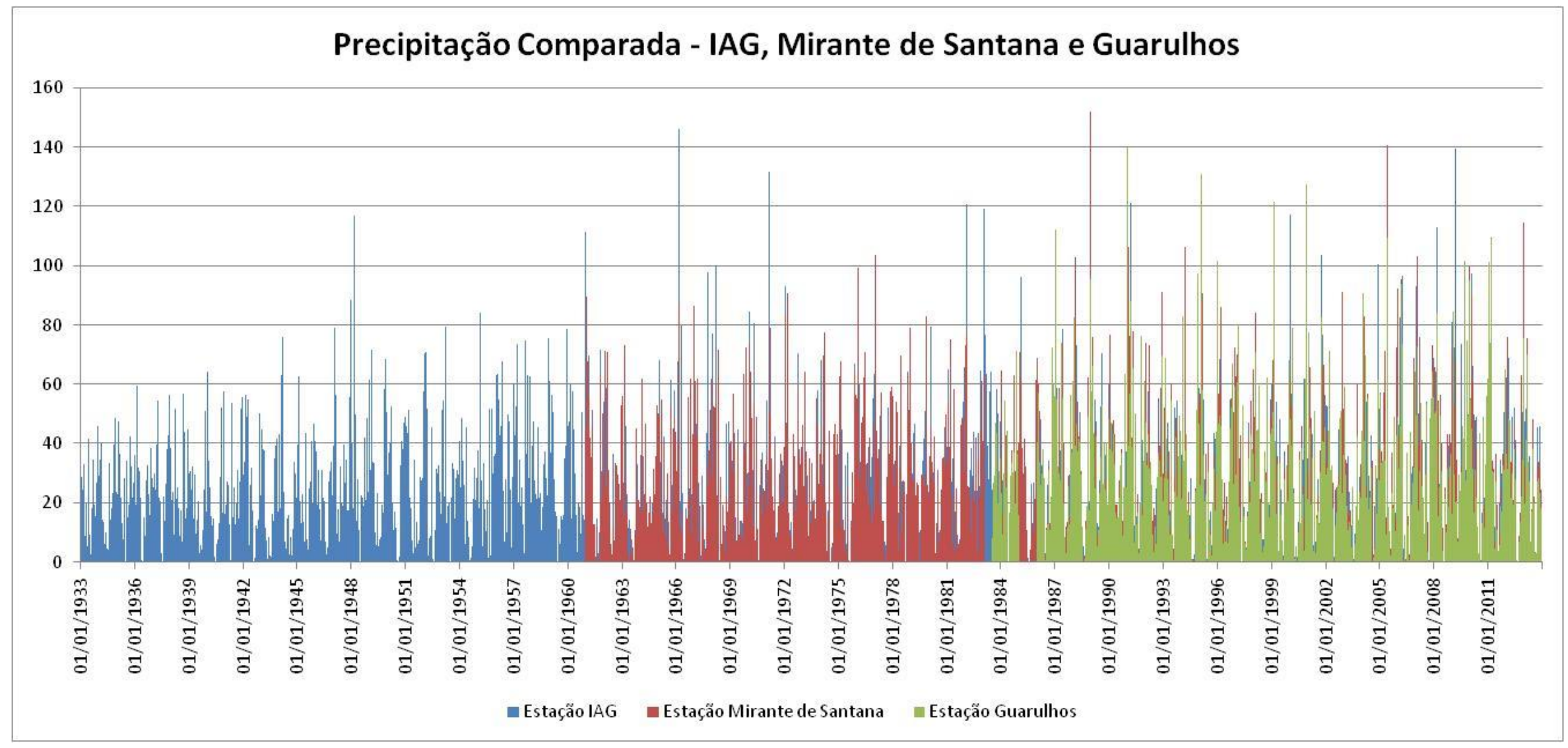




\section{ANEXO}

Correspondência com a SABESP 


\section{Re: Dados dos volumes de armazenamento dos mananciais.}

- De: crodrigues@sabesp.com.br

Para: gabrielan!@usp.br

Marcadores: Lembrar depois

Bom dia Gabriela

Primeiramente, agradecemos o interesse em utilizar a Sabesp como fonte de informações para seu trabalho

No momento, por conta da crise hidrica, toda a atenção da Sabesp está voltada para soluções e melhorias de abastecimento da população e estamos focando muitas ações neste sentido, o que nos impossibilita de atender outras solicitações e dentre elas as acadêmicas.

De qualquer forma todas as informações públicas que temos estão disponiveis no site, alunos de diversas áreas estão consultando estas informações para desenvolver excelentes trabalhos acadêmicos.

Esperamos poder ajudá-la futuramente.

Atenciosamente,

Carlos Eduardo Rodrigues

Gerente Produçã̃o de Comunicaçăo

Superintendência de Comunicaşão - PC

(11) 3388-9447

俩 (11) 3388-859

国 